\title{
(ब)
}

AUTARQUIA ASSOCIADA À UNIVERSIDADE DE SÃO PAULO

\section{DESENVOLVIMENTO DE ELASTÔMEROS FLUORADOS MULTIFUNCIONAIS BASEADOS EM NANOCOMPÓSITOS}

Heloísa Augusto Zen

Tese apresentada como parte dos requisitos para obtenção do Grau de Doutor em Ciências na Área de Tecnologia Nuclear - Materiais

Orientador:

Prof. Dr. Ademar Benévolo Lugão 


\title{
INSTITUTO DE PESQUISAS ENERGÉTICAS E NUCLEARES
}

Autarquia associada à Universidade de São Paulo

\section{DESENVOLVIMENTO DE ELASTÔMEROS FLUORADOS MULTIFUNCIONAIS BASEADOS EM NANOCOMPÓSITOS}

\author{
Heloísa Augusto Zen
}

\begin{abstract}
Tese apresentada como parte dos requisitos para obtenção do Grau de Doutor em Ciências na Área de Tecnologia Nuclear - Materiais

Orientador:

Prof. Dr. Ademar Benévolo Lugão
\end{abstract}

Versão Corrigida

Versão Original disponível no IPEN 
Dedico este trabalho aos meus pais, João e Ancile, que sempre me concederam o direito de escolha. 


\section{AGRADECIMENTOS}

Ao meu orientador Dr. Ademar Benévolo Lugão pelo suporte, pela orientação e pela confiança durante todo o desenvolvimento desta tese.

À minha família Zen pelo apoio e incentivo durante todo o desenvolvimento deste trabalho.

Ao meu marido Erik Lorne de Mesquita que nunca mediu esforços para que eu pudesse alcançar este objetivo.

A Comissão Nacional de Energia Nuclear (CNEN) pela bolsa concedida.

Ao Instituto de Pesquisas Energéticas e Nucleares (IPEN/CNEN - SP) pela oportunidade de desenvolver este trabalho.

Às amigas Elizabeth Carvalho Leite Cardoso, Sandra Regina Scagliusi e Paula Pinheiro Paganini pela amizade e paciência.

Aos amigos Edson Takeshi Osaki, João Batista de Andrade e Camila Pereira de Souza (in memoriam) pelo apoio e carinho demonstrado.

Aos alunos de iniciação científica, Jonathan Pereira de Oliveira, Renato Guimarães dos Santos, Paula Gabriela Silva Pereira e Yago Mascarenha (CQMAIPEN) pelo apoio na preparação das amostras.

Ao Sr. Eleosmar Gasparin do laboratório de Síntese e Caracterização de polímeros (CQMA-IPEN) pelas análises térmicas.

Ao Dr. Pablo Antonio Vasquez Salvador e sua equipe do laboratório Irradiador Multipropósito do Centro de Tecnologia das Radiações (CTR-IPEN) pela irradiação das amostras. 
À Dra. Susy Frey Sabato do CTR-IPEN pela utilização do equipamento de ensaios mecânicos.

Ao Sr. Celso Vieira de Moraes, Sr. Nildemar Aparecido Messias Ferreira, ao Sr. Glauson Aparecido Ferreira Machado e à Dra. Flavia Rodrigues de Oliveira Silva do laboratório de Microscopia e Microanálise do Centro de Ciência e Tecnologia de Materiais (CCTM-IPEN) pelas análises de microscopia.

Ao Sr. Marcelo Silva da empresa Flexlab Consultoria e Treinamento Ltda. pela mistura dos compostos de borracha com as nanopartículas.

A todos os colegas do Centro de Química e Meio Ambiente (CQMAIPEN) pelo apoio durante o desenvolvimento deste trabalho.

À Comissão de Pós Graduação, à sra. Ana Claudia Martinelli Feher e sua equipe da secretaria de pós graduação por todo apoio e esclarecimentos prestados.

Aos professores da banca examinadora: Prof. Dr. Carlos Henrique Scuracchio, Prof. Dra. Geise Ribeiro, Prof. Dr. Giovanni Gonzalez Perez e Prof. Dra. Regina Célia Reis Nunes.

Aos meus amigos que sempre estiveram ao meu lado apoiando e incentivando durante o desenvolvimento deste trabalho. 
Tente mover o mundo - o primeiro passo será mover a si mesmo.

\section{Platão}




\title{
DESENVOLVIMENTO DE ELASTÔMEROS FLUORADOS MULTIFUNCIONAIS BASEADOS EM NANOCOMPÓSITOS
}

\author{
HELOÍSA AUGUSTO ZEN
}

RESUMO

Os polímeros fluorados são conhecidos por suas ótimas propriedades mecânicas, pela alta estabilidade térmica e pela resistência a ambientes químicos agressivos, e por causa destas propriedades são muito utilizados em indústrias automobilística, petroquímica, de manufatura, dentre outras. Para aprimorar as propriedades térmicas e de barreira a gases da matriz polimérica, é muito utilizado a incorporação de nanopartículas nesta matriz, pois após a incorporação o nanocompósito permanece com suas próprias características e adquire novas propriedades devido a presença da nanopartícula. Devido as características dos fluoropolímeros, sua modificação estrutural e morfológica é muito difícil de ser obtida por técnicas tradicionais e para transpor essa dificuldade a radiação ionizante é uma técnica muito utilizada e eficaz para a alteração estrutural de polímeros fluorados. Neste trabalho foram desenvolvidos nanocompósitos poliméricos à base de fluoroelastômero (FKM) incorporado com quatro diferentes nanopartículas: argila Cloisite 15A, POSS 1159, POSS 1160 e POSS 1163. Após obtenção dos filmes de nanocompósitos foi realizado o processo de enxertia de estireno induzida por radiação ionizante, seguida de sulfonação para obtenção de membrana trocadora de íons. O efeito da incorporação de nanopartículas e da radiação ionizante nos filmes desenvolvidos foram caracterizados por difração de raios $X$, análise térmica, análise mecânica, microcospia eletrônica de varredura e intumescimento; enquanto que as membranas obtidas foram avaliadas quanto ao grau de enxertia, capacidade de troca iônica e intumescimento. Após a caracterização os filmes, foi verificado que a reticulação foi o efeito predominante nos nanocompósitos irradiados antes da vulcanização, enquanto que a degradação foi o efeito predominante nos nanocompósitos irradiados após a vulcanização. 


\title{
DEVELOPMENT OF MULTIFUNCTIONAL FLUOROELASTOMERS BASED ON NANOCOMPOSITES
}

\author{
HELOÍSA AUGUSTO ZEN
}

\begin{abstract}
The fluoropolymers are known for their great mechanical properties, high thermal stability and resistance to aggressive chemical environment, and because of those properties they are widely used in industries, such as automobile, petroleum, chemistry, manufacturing, among others. To improve the thermal properties and gases barrier of the polymeric matrix, the incorporation of nanoparticle is used, this process permits the polymer to maintain their own characteristics and acquire new properties of nanoparticle. Because of those properties, the structural and morphological modification of fluoropolymers are very hard to be obtained through traditional techniques, in order to surmount this difficulty, the ionizing radiation is a well-known and effective method to modify fluoropolymers structures. In this thesis a nanocomposite polymeric based on fluoroelastomer (FKM) was developed and incorporated with four different configurations of nanoparticles: clay Cloisite 15A, POSS 1159, POSS 1160 and POSS 1163. After the nanocomposites films were obtained, a radiation induced grafting process was carried out, followed by sulfonation in order to obtain a ionic exchanged membrane. The effect of nanoparticle incorporation and the ionizing radiation onto films were characterized by X-ray diffraction, thermal and mechanical analysis, scanning electron microscopy and swelling; and the membranes were evaluated by degree of grafting, ionic exchange capacity and swelling. After the films were characterized, the crosslinking effect was observed to be predominant for the nanocomposites irradiated before the vulcanization, whereas the degradation was the predominant effect in the nanocomposites irradiated after vulcanization.
\end{abstract}




\section{SUMÁRIO}

1 INTRODUÇÃO .1

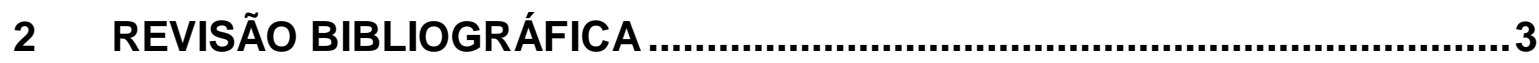

2.1 Elastômero Fluorado ……...................................................................

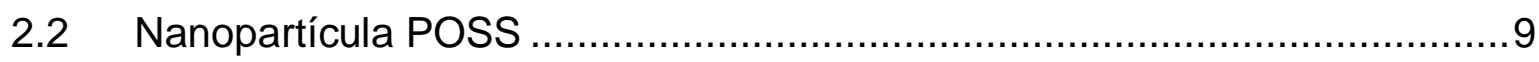

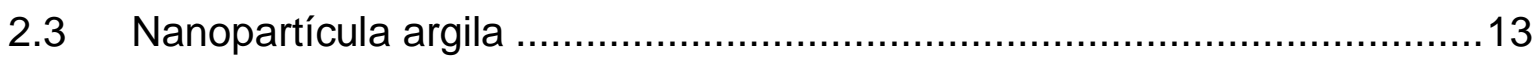

2.4 O processo de enxertia induzida por radiação ionizante ...........................19

2.5 Reação de sulfonação dos filmes enxertados .........................................24

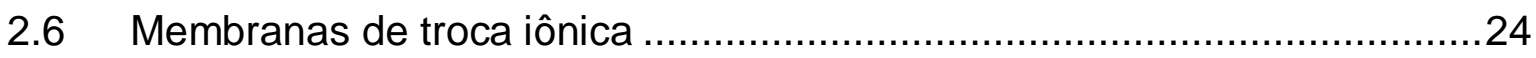

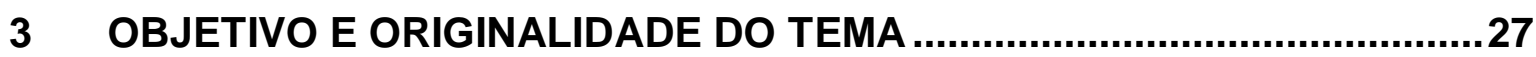

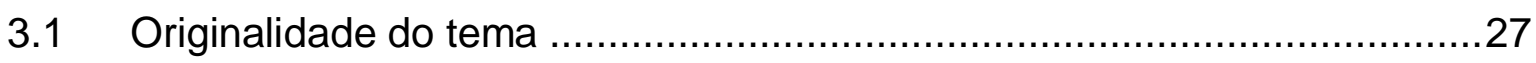

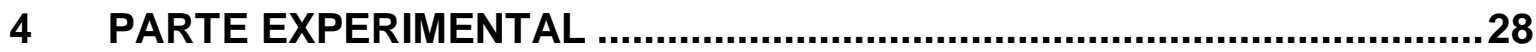

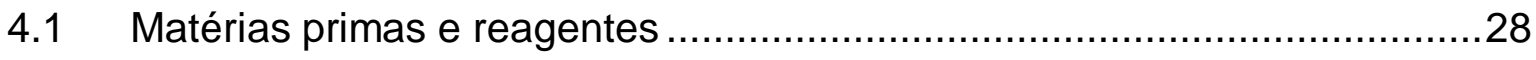

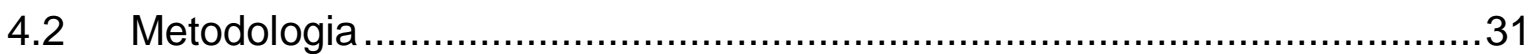

4.2.1 Obtenção dos filmes de FKM incorporados com

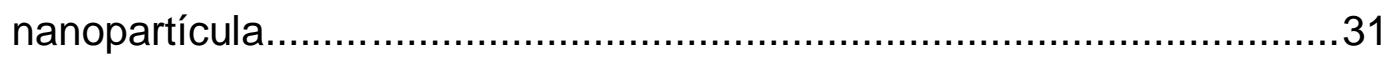

4.2.2 Processamento por irradiação ............................................. 31

4.2.3 Processo de enxertia induzida por radiação gama, seguida de sulfonação

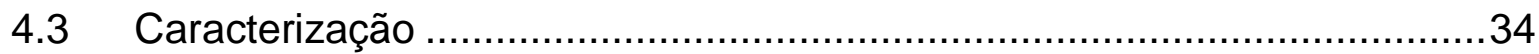

4.3.1 Ensaio de tração.............................................................

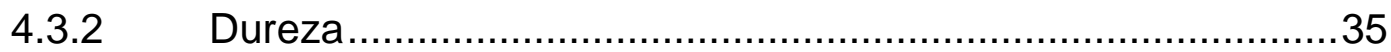

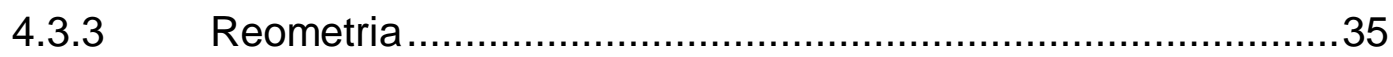


4.3.4 Índice de Intumescimento (Swelling) ....................................36

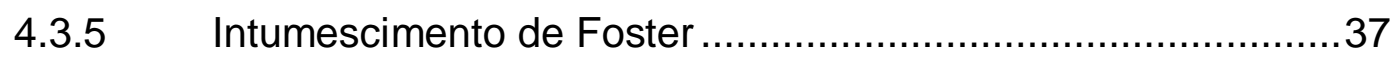

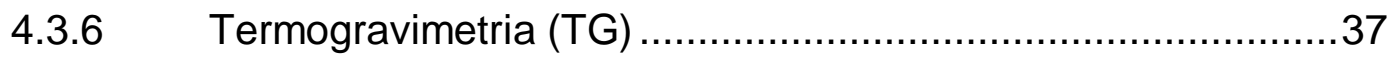

4.3.7 Microscopia eletrônica de varredura (MEV) ............................38

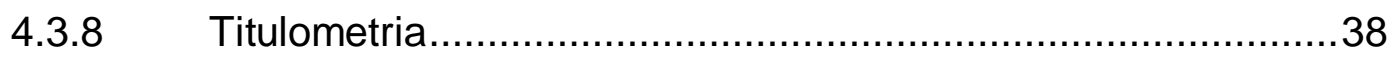

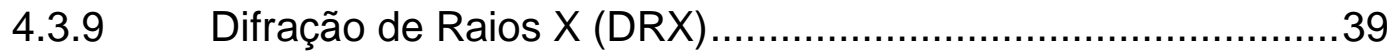

5 RESULTADOS E DISCUSSÃo

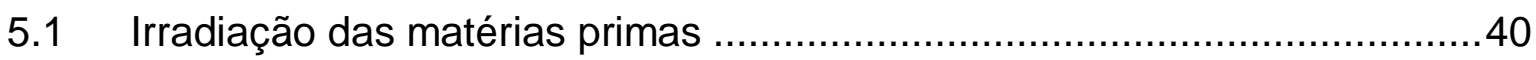

5.1.1 Efeito da radiação ionizante em argila - Cloisite 15A.............. 40

5.1.2 Efeito da radiação ionizante em POSS 1163 ........................47

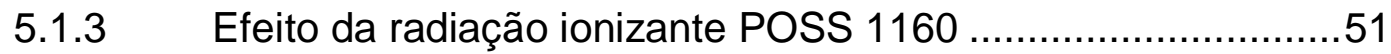

5.1.4 Efeito da radiação ionizante em POSS 1159 .........................54

5.1.5 Efeito da radiação ionizante em elastômero não vulcanizado. 57

5.1.6 Efeito da radiação ionizante em elastômero vulcanizado.........61

5.1.7 Efeito da radiação ionizante antes da vulcanização do elastômero.

5.2 Efeito da radiação ionizante nos filmes de nanocompósitos após o processo de vulcanização

5.3 Efeito da radiação ionizante nos filmes de nanocompósitos antes do processo de vulcanização 86

5.4 Enxertia induzida por radiação gama seguida de sulfonação .98

6 CONCLUSÃO 105

APÊNDICE A - RESULTADOS DE INTUMESCIMENTO EM TOLUENO PARA OS FILMES DE FKM INCORPORADOS COM NANOPARTÍCULA, VULCANIZADOS ANTES DA IRRADIAÇÃO E DO FILME NÃO IRRADIADO. ..106

APÊNDICE B - RESULTADOS DE INTUMESCIMENTO EM TOLUENO PARA OS FILMES DE FKM INCORPORADOS COM NANOPARTÍCULA, VULCANIZADOS APÓS A IRRADIAÇÃO E DO FILME NÃO IRRADIADO 
APÊNDICE C - CURVAS DE TENSÃO X DEFORMAÇÃO PARA OS FILMES INCORPORADOS COM NANOPARTÍCULA, VULCANIZADOS ANTES DA IRRADIAÇÃO E DO FILME NÃO IRRADIADO.............................................110

APÊNDICE D - CURVAS DE TENSÃO X DEFORMAÇÃO PARA OS FILMES INCORPORADOS COM NANOPARTÍCULA, VULCANIZADOS APÓS A IRRADIAÇÃO E DO FILME NÃO IRRADIADO............................................114

REFERÊNCIAS BIBLIOGRÁFICAS..........................................................118 


\section{ÍNDICE DE FIGURAS}

FIGURA 1 - Representação do POSS® Octahíbrido (SH 1311), o modelo de gaiola com hidrogênio nos cantos [25] ......................................................

FIGURA 2 - Imagem da argila montmorilonita [45]....................................... 14 FIGURA 3 - Estrutura cristalográfica octaédrica da argila montmorilonita,

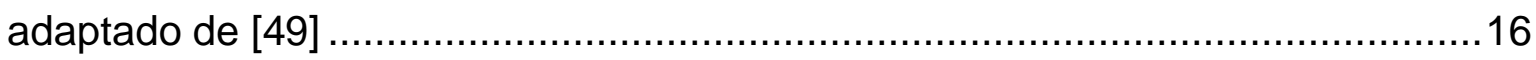
FIGURA 4 - Representação esquemática dos dois tipos de nanocompósitos de argila-polímero [50].

FIGURA 5 - Mecanismo simplificado da interação da radiação ionizante com a matriz polimérica.

FIGURA 6 - Mecanismo da reação de degradação oxidativa como resultado da Interação da radiação ionizante com o fluoreto de vinilideno (adaptado de 79)....22 FIGURA 7- Mecanismo da reação de reticulação como resultado da Interação da radiação ionizante com o fluoreto de vinilideno (adaptado de 79) .22 FIGURA 8 - Mecanismo da reação de degradação por cisão de cadeia como resultado da Interação da radiação ionizante com o FKM (adaptado de 79) .........23 FIGURA 9 - Estrutura molecular do POSS OL1159 ….....................................28

FIGURA 10 - Estrutura molecular do POSS OL1160 …………………….......29

FIGURA 11 - Estrutura molecular do POSS OL1163 ……..............................29

FIGURA 12 - Estrutura molecular do fluoroelastômero terpolímero formado por, $\mathrm{VF}_{2}$, HFP e TFE.

FIGURA 13 - Representação da curva obtida pela análise de reometria, adaptado de [100] .36

FIGURA 14 - Resultado do intumescimento de Foster para argila Cloisite 15A em água a) após 24h e b) após $48 \mathrm{~h}$

FIGURA 15 - Resultado do intumescimento de Foster para argila em tolueno: a) após $24 \mathrm{~h}$ e b) após $48 \mathrm{~h}$ 42

FIGURA 16 - Resultado do intumescimento de Foster para argila em MEK: a) após $24 \mathrm{~h}$ e b) após $48 \mathrm{~h}$ 43

FIGURA 17 - Curvas TG e DTG obtidas em atmosfera de $\mathrm{N}_{2}$ para as amostras de argila Cloisite $15 \mathrm{~A}$ antes e depois da irradiação.

FIGURA 18 - Difratogramas de raios $X$ das amostras de argila Cloisite 15A antes e depois da irradiação e em barras da montmorilonita. 
FIGURA 19 - Imagens de microscopia eletrônica de varredura das amostras de argila Cloisite 15A antes e depois da irradiação.

FIGURA 20 - Curvas TG e DTG obtidas para as amostras de POSS 1163 antes e depois do processo de irradiação

FIGURA 21 - Difratogramas de raios X para as amostras de POSS 1163 antes e depois do processo de irradiação. .50

FIGURA 22 - Imagens de microscopia eletrônica de varredura das amostras de POSS 1163 antes e depois do processo de irradiação

FIGURA 23 - Curvas TG e DTG obtidas para as amostras de POSS 1160 irradiada e não irradiada

FIGURA 24 - Difratogramas de raios X para as amostras de POSS 1160 irradiada e não irradiada.

FIGURA 25 - Imagens de microscopia eletrônica de varredura de POSS 1160 antes e depois da irradiação

FIGURA 26 - Curvas TG e DTG obtidas para as amostras de POSS 1159 antes e depois da irradiação

FIGURA 27 - Difratogramas de raios X para as nanopartículas 1159 antes e depois da irradiação. .56

FIGURA 28 - Imagens de microscopia eletrônica de varredura das amostras de POSS 1159 antes e depois da irradiação.

FIGURA 29 - Curvas TG e DTG obtidas para o elastômero não vulcanizado antes e depois do processo de radiação .58

FIGURA 30 - Imagens de microscopia eletrônica de varredura das amostras de elastômero não vulcanizado antes e depois da irradiação

FIGURA 31 - TG e DTG do elastômero vulcanizado não irradiado e vulcanizado antes da irradiação.

FIGURA 32 - Curvas tensão x deformação dos filmes FKM não irradiado e vulcanizados antes da irradiação. 63

FIGURA 33 - Valores de dureza para o elastômero FKM não irradiado e vulcanizado antes da irradiação.

FIGURA 34 - Resultado de intumescimento do filme de elastômero FKM não irradiado e vulcanizado antes da irradiação, em diferentes solventes. 66 FIGURA 35 - Imagens de microscopia eletrônica de varredura das amostras de elastômero vulcanizado antes e depois da irradiação 
FIGURA 36 - Curvas de tensão $x$ deformação dos filmes FKM não irradiado e vulcanizados após a irradiação .68

FIGURA 37 - Dureza do elastômero FKM não irradiado e vulcanizado após a irradiação.

FIGURA 38 - Intumescimento dos filmes de FKM vulcanizados após a irradiação e do filme não irradiado em diferentes solventes .71 FIGURA 39 - Resultado do ensaio de dureza dos filmes FKM incorporados com argila Cloisite 15A, vulcanizados antes da irradiação e não irradiado. .77 FIGURA 40 - Resultado do ensaio de dureza dos filmes FKM incorporados com POSS 1159, vulcanizados antes da irradiação e não irradiado. .77 FIGURA 41 - Resultado do ensaio de dureza dos filmes FKM incorporados com POSS 1160, vulcanizados antes da irradiação e não irradiado. .78 FIGURA 42 - Resultado do ensaio de dureza dos filmes FKM incorporados com POSS 1163, vulcanizados antes da irradiação e não irradiado. .78 FIGURA 43 - Resultado do teste de intumescimento em MEK dos filmes FKM incorporados com argila Cloisite 15A vulcanizados antes da irradiação e não irradiado.

FIGURA 44 - Resultado do teste de intumescimento em MEK dos filmes FKM incorporados com POSS 1159 vulcanizados antes da irradiação e não irradiado.

FIGURA 45 - Resultado do teste de intumescimento em MEK dos filmes FKM incorporados com POSS 1160, vulcanizados antes da irradiação e não irradiado.

FIGURA 46 - Resultado do teste de intumescimento em MEK dos filmes FKM incorporados com POSS 1163 vulcanizados antes da irradiação e não irradiado.

FIGURA 47 - Imagens de microscopia eletrônica de varredura dos filmes FKM incorporados com argila Cloisite 15A vulcanizados antes da irradiação e não irradiado.

FIGURA 48 - Imagens de microscopia eletrônica de varredura dos filmes FKM incorporados com POSS 1159 vulcanizados antes da irradiação e não irradiado. 
FIGURA 49 - Imagens de microscopia eletrônica de varredura dos filmes FKM incorporados com POSS 1160 vulcanizados antes da irradiação e não irradiado.

FIGURA 50 - Imagens de microscopia eletrônica de varredura dos filmes FKM incorporados com POSS 1163 vulcanizados antes da irradiação e não irradiado.

FIGURA 51 - Resultado do ensaio de dureza dos filmes FKM incorporados com argila Cloisite 15A, vulcanizados após a irradiação e da amostra não irradiada. .92 FIGURA 52 - Resultado do ensaio de dureza dos filmes FKM incorporados com POSS 1159 vulcanizados após a irradiação e da amostra não irradiada .93 FIGURA 53 - Resultado do ensaio de dureza dos filmes FKM incorporados com POSS 1160 vulcanizados após a irradiação e da amostra não irradiada .93 FIGURA 54 - Resultado do ensaio de dureza dos filmes FKM incorporados com POSS 1163 vulcanizados após a irradiação e da amostra não irradiada .94 FIGURA 55 - Resultado do teste de intumescimento em MEK dos filmes FKM incorporados com argila Cloisite 15A vulcanizados após a irradiação e do filme não irradiado

FIGURA 56 - Resultado do teste de intumescimento em MEK dos filmes FKM incorporados com POSS 1159 vulcanizados após a irradiação e do filme não irradiado .96

FIGURA 57 - Resultado do teste de intumescimento em MEK dos filmes FKM incorporados com POSS 1160 vulcanizados após a irradiação e do filme não irradiado.

FIGURA 58 - Resultado do teste de intumescimento em MEK dos filmes FKM incorporados com POSS 1163 vulcanizados após a irradiação e do filme não irradiado .98

FIGURA 59 - Imagens das membranas após a reação de sulfonação (menor tamanho) e após o intumescimento em água (maior tamanho). 104 


\section{ÍNDICE DE TABELAS}

TABELA 1: Monômeros utilizados para a produção do fluoroelastômero [1]. 4

TABELA 2 - Resultados da análise térmica sob atmosfera da argila Cloisite 15A irradiada e não irradiada.

TABELA 3: Resultados da análise termogravimétrica em nitrogênio para o POSS 1163 antes e depois do processo de irradiação.

TABELA 4 - Resultados da análise termogravimétrica em nitrogênio para o POSS 1160 antes e depois do processo de irradiação.

TABELA 5 - Resultados da análise termogravimétrica em nitrogênio para o POSS 1159 antes e depois do processo de irradiação.

TABELA 6 - Resultados da análise termogravimétrica em nitrogênio para 0 elastômero não vulcanizado antes e depois do processo de irradiação. .58 TABELA 7 - Resultados da difração de raios $X$ para o fluoroelastômero não vulcanizado antes e depois irradiação.

TABELA 8 - Resultados da análise termogravimétrica em nitrogênio para o elastômero vulcanizado (FKM) antes e depois do processo de irradiação.

TABELA 9: Valores de tensão e alongamento na ruptura e do módulo a $25 \%$ para os filmes não irradiado e vulcanizados antes da irradiação

TABELA 10: Valores de tensão e alongamento na ruptura e módulo a $25 \%$ dos filmes FKM não irradiado e vulcanizados após a irradiação 69

TABELA 11 - Valores de tensão e alongamento na ruptura para os filmes FKM incorporados com argila Cloisite 15A, vulcanizados antes da irradiação e não irradiado.

TABELA 12 - Valores de tensão e alongamento na ruptura para os filmes FKM incorporados com POSS 1159 vulcanizados antes da irradiação e não irradiado.

TABELA 13 - Valores de tensão e alongamento na ruptura para os filmes FKM incorporados com POSS 1160 vulcanizados antes da irradiação e não irradiado.

TABELA 14 - Valores de tensão e alongamento na ruptura para os filmes FKM incorporados com POSS 1163, vulcanizados antes da irradiação e não irradiado. 
TABELA 15 - Valores de tensão e alongamento na ruptura para os filmes FKM incorporados com argila Cloisite 15A, vulcanizados após a irradiação e não irradiado. .88

TABELA 16 - Valores de tensão e alongamento na ruptura para os filmes FKM incorporados com POSS 1159, vulcanizados após a irradiação e não irradiado.. 89 TABELA 17 - Valores de tensão e alongamento na ruptura para os filmes FKM incorporados com POSS 1160, vulcanizados após a irradiação e não irradiado..90 TABELA 18 - Valores de tensão e alongamento na ruptura para os filmes FKM incorporados com POSS 1163, vulcanizados após a irradiação e não irradiado.. 91 TABELA 19 - Resultados obtidos do cálculo de GE, do IEC e do intumescimento em água dos filmes e membranas. 102 
Uma classe de polímero muito pesquisada é o elastômero ou borracha. Este polímero é caracterizado pelo alto alongamento e pela ausência da fase cristalina em sua estrutura sendo, portanto, um polímero amorfo. Por ser amorfo o elastômero possui alta mobilidade da cadeia polimérica que só é reduzida após a incorporação de cargas e do processo de vulcanização. Este processo de vulcanização é responsável pela formação da rede tridimensional que favorece a alta resistência mecânica inerente aos elastômeros. Existem diversos tipos de borrachas dependendo de sua estrutura química: nitrílica, butadieno, natural, clorada, hidrogenada, fluorada, dentre outras.

Para este trabalho foi escolhido 0 elastômero fluorado (fluoroelastômero, FKM) formado por três monômeros: hexafluoropropileno, fluoreto de vinilideno e tetrafluoroetileno. O FKM é conhecido por possuir boas propriedades térmicas, químicas e mecânicas e por isso é utilizado em diversos segmentos industriais, tais como: aeroespacial, naval, petroquímica, automobilístico, entre outros. Uma das vantagens deste polímero é sua resistência a alta temperatura em uso contínuo, o que faz desse material um dos mais utilizados como anéis de vedação e gaxetas.

Para aprimorar a resistência a combustíveis, a solventes orgânicos, a bases e a ácidos, muitos pesquisadores incorporaram cargas de diferentes funcionalidades. Com o avanço da pesquisa nessa área, verificou-se que a incorporação de nanopartículas inorgânicas contribuiu e aprimorou não somente as propriedades citadas, como também em muitos casos a resistência mecânica e a propriedade de barreira a gases.

A incorporação de nanopartículas inorgânicas em polímeros formam os nanocompósitos poliméricos (PNs) que possuem características de polímeros de 
alta performance quando comparados com os polímeros com cargas de tamanho micrométrico. Esta alta performance está relacionada com melhora das propriedades térmicas, de resistência à chama, decréscimo na permeabilidade e da resistência química. A nanopartícula incorporada na matriz polimérica possui tamanho de partícula na escala de nanômetro $\left(10^{-9} \mathrm{~m}\right)$ e com pelo menos uma de suas dimensões inferior a $100 \mathrm{~nm}$.

Estes nanocompósitos são utilizados em larga escala em diversas áreas da indústria como aeroespacial, automotiva, manufatura, petroquímica, entre outras. Esta utilização está relacionada com inúmeros grupos de pesquisas presentes dentro da indústria e em centros de pesquisa que desenvolveram ao longo dos últimos anos técnicas de caracterização que permitiu aos pesquisadores avaliarem as propriedades morfológicas, interfaciais e também possibilitou prever as propriedades adquiridas ou melhoradas dos nanocompósitos. A incorporação destas nanopartículas em FKM é facilitada pela solubilidade do elastômero, que possibilita uma distribuição homogênea destas no interior do fluoroelastômero.

A modificação de polímeros fluorados por meios tradicionais, como peróxidos ou processos químicos é difícil devido às fortes ligações C-F presentes na cadeia polimérica. Uma técnica muito utilizada para a modificação destas matrizes é a utilização da radiação ionizante, que para este tipo de polímero pode ser mais eficiente que os métodos tradicionais.

Este trabalho desenvolveu uma membrana de troca iônica pelo método da enxertia induzida por radiação gama, seguida de sulfonação. Para obtenção desta membrana, quatro diferentes tipos de nanopartículas foram incorporadas no composto de FKM e após a obtenção dos nanocompósitos foi realizado o processo de enxertia sob radiação gama. 


\section{REVISÃo BIBLIOGRÁFICA}

\subsection{Elastômero Fluorado}

As borrachas podem ser natural ou sintética e existem diferentes tipos como: copolímero estireno-butadieno, poliisopreno, polibutadieno, copolímero etileno-propileno, policloropreno, copolímero acrilonitrila-butadieno, polibutileno, poliuretano, polisulfida, policlorosulfonato, poliacrilato, polifluorocarbono (os fluoroelastômeros, FKM), silicones, etc. Para o desenvolvimento deste trabalho foi escolhido o elastômero do tipo fluorado (fluoroelastômero, FKM), por possuir propriedades químicas e físicas necessárias para atuar em condições agressivas de operação. Os fluoroelastômeros mais utilizados e produzidos são copolímeros de vinilideno fluorado $\left(\mathrm{VF}_{2}\right)$ com outro monômero fluorado como o hexafluoropropileno (HFP) e/ou o tetrafluoroetileno (TFE). Na TABELA 1 estão descritos alguns monômeros que são utilizados para a produção dos diferentes tipos de fluoroelastômeros,

Elastômero (ou borracha) é um polímero que apresenta deformação reversível quando submetido à tensão. Esta deformação depende da rotação de em torno de suas ligações que é alterada pelos ângulos diedros. Para que esta deformação ocorra o elastômero deve ser predominantemente amorfo para que a flexibilidade da cadeia não seja inibida pela cristalização.

Este polímero é constituído de moléculas flexíveis que se aglomeram aleatoriamente e formam 0 emaranhamento molecular da cadeia. Esta flexibilidade da cadeia polimérica depende do volume livre que possibilita 0 movimento dos segmentos da cadeia. Suas cadeias flexíveis podem se mover através de sucessivos deslocamentos de grupos de unidades ou segmentos. A energia necessária para a separação de sua cadeia é menor, e é superada pela 
energia liberada da interação polímero-solvente. Por isso polímeros flexíveis que são apolares são usualmente miscíveis em líquidos apolares.

TABELA 1: Monômeros utilizados para a produção do fluoroelastômero [1].

\begin{tabular}{|c|c|c|c|c|}
\hline Monômero & Nomenclatura & Fórmula & $\begin{array}{c}\% \\
\mathrm{CeH}\end{array}$ & $\begin{array}{c}\% \\
\text { C e F }\end{array}$ \\
\hline Fuoreto de vinilideno & $\mathrm{VF}_{2}$ & $\mathrm{CH}_{2}=\mathrm{CF}_{2}$ & 40,6 & 59,4 \\
\hline Perfluorometil vinil éter & PFMVE & $\mathrm{CF}_{2}=\mathrm{CF}-\mathrm{O}-\mathrm{CF}_{3}$ & 21,7 & 68,7 \\
\hline $\begin{array}{l}1- \\
\text { Hidropentafluoropropileno }\end{array}$ & HPFP & $\mathrm{CHF}=\mathrm{CF}-\mathrm{CF}_{3}$ & 28 & 72 \\
\hline Hexafluoropropileno & HFP & $\mathrm{CF}_{2}=\mathrm{CF}-\mathrm{CF}_{3}$ & 24 & 76 \\
\hline Tetrafluoroetileno & TFE & $\mathrm{CF}_{2}=\mathrm{CF}_{2}$ & 24 & 76 \\
\hline Trifluorocloroetileno & TFCIE & $\mathrm{CFCl}=\mathrm{CF}_{2}$ & 20,6 & 79,4 \\
\hline
\end{tabular}

Os fluoroelastômeros foram introduzidos no mercado no final dos anos 1950 e desde então diversas pesquisas têm sido feitas para oferecer FKM com diferentes níveis de resistência química e diferentes sistemas de cura que melhoram suas propriedades mecânicas e de sua resistência ao calor permitindo temperatura de uso continuo de $205^{\circ} \mathrm{C}$. Durante o processo de cura ou vulcanização, o elastômero cria uma estrutura tridimensional (reticulação), devido às ligações cruzadas, o que faz com que o material seja adequado para suportar longos períodos de estresse e de tensão. Além dessas propriedades, outras características podem ser atribuídas ao FKM, tais como: resistência à chama e à oxidação; resistência a combustíveis, solvente e óleos; e resistência a ambientes quimicamente agressivos como em meio básico e com hidrocarbonetos aromáticos. Esta resistência química e ao calor pode ser atribuída a alta energia de ligação do $\mathrm{C}-\mathrm{F}$, que é mais forte que as ligações $\mathrm{C}-\mathrm{C}, 480 \mathrm{~kJ}^{\mathrm{mol}}{ }^{-1}$, e $370 \mathrm{~kJ} \cdot \mathrm{mol}^{-1}$, respectivamente.

Devido a estas características citadas, o FKM é muito utilizado nas indústrias petroquímica, de manufatura, automotiva e aeroespacial, sendo 
extensivamente utilizado como gaxetas e anéis de vedação (O-ring) por causa de sua ótima resistência à compressão.

O fluoroelastômero também pode ser utilizado como selo inflável em reator nuclear. Os pesquisadores Sinha e Raj [2 - 6] do Centro de Pesquisa Atômica Indira Ghandi, da Índia, publicaram diversos trabalhos relatando os resultados obtidos após os testes deste material em substituição à borracha de silicone.

A utilização do FKM na indústria de petróleo como anel de vedação enfrenta a grande dificuldade de controlar a desorção do gás absorvido, pois durante esta desorção ocorre a formação de rachaduras o que pode resultar em graves acidentes. Os pesquisadores Cadambi e Ghassemieh [7] depositaram uma fina camada de cromo ( $\mathrm{Cr}$ ) e de carboneto de tungstênio (WC) como revestimento em três diferentes tipos de borracha butadieno-nitrila-hidrogenada (HNBR), fluoroelastômero (FKM) e silicone. Os autores obtiveram bom resultado de adesão da camada de metal nas matrizes estudadas quando avaliadas em baixa temperatura $\left(-125^{\circ} \mathrm{C}\right)$, o que foi confirmado pelos resultados dos testes mecânicos. Após os testes de permeabilidade a gases, os pesquisadores verificaram uma redução de transmissão de gás e de resistência ao desgaste, representando um aumentou em mais de $40 \%$ na resistência à permeabilidade, os pesquisadores concluíram que esses materiais estudados podem ser utilizados em contato com gases químicos.

Wei et al. [8] estudaram os efeitos da incorporação de óxido de grafeno (GO) em fluoroelastômero para diminuir a perda de propriedade mecânica (resistência à tensão) e de barreira a líquido quando o material é utilizado como selante na indústria de petróleo. A incorporação foi realização pelas técnicas de ultrassom e de co-coagulação e eles concluíram que o GO efetivamente contribuiu para melhorar as propriedades mecânicas e de barreira de acordo com os resultados obtidos após os ensaios de tensão e de intumescimento.

Bouzek e colaboradores [9] estudaram e prepararam membranas heterogêneas pela mistura de partículas de Amberlite 252 (poliestireno sulfonado) 
como trocador de íons em quatro matrizes poliméricas com diferentes estruturas e propriedades mecânicas. As matrizes poliméricas estudadas foram polietileno linear com alta flexibilidade de cadeia, fluoroelastômero com média flexibilidade, poliestireno rígido e hidrofóbico, e celulose hidrofílica. Os pesquisadores investigaram o comportamento destas matrizes como membranas trocadora de íons para uma futura utilização em célula a combustível a metanol. Pela análise de microscopia eletrônica de transmissão, eles verificaram a existência de cavidades adicionais nas membranas de polietileno e do fluoroelastômero que indicaram a não interação com o ionômero. Os autores concluíram que as membranas de polietileno com Amberlite e do fluoroelastômero com Amberlite foram as que obtiveram melhores resultados devido à penetração das partículas trocadoras de íons nas finas camadas dos polímeros, porém pela avaliação das propriedades mecânicas a membrana de polietileno apresentou melhores resultados quando comparada à de fluoroelastômero.

Uma de muitas aplicações industriais, incluindo em célula a combustível, da borracha é como anel de vedação. Um estudo feito por Li et al. [10] mostrou o efeito de degradação química nesta borracha quando exposta à cinco diferentes soluções ácidas a temperatura de $70^{\circ} \mathrm{C}$. Pela análise gravimétrica verificaram que a perda de massa das amostras é proporcional ao aumento da concentração da solução e do tempo de exposição, o que foi corroborado pela análise de microscopia com a qual foi observado o aparecimento de rachaduras e rugosidades.

Liu e Wilson [11] investigaram o impacto dos solventes n-decano, isoparafina e decalin, geralmente utilizados em combustível de aeronaves, nas propriedades de anés de vedação (o-ring). Os autores testaram os três solventes em três tipos de anéis fabricados a partir de borracha nitrílica, fluorocarbono e fluorosilicone. O teste de resistência consistiu na compressão do anel até reduzílo em $25 \%$ do tamanho original, em seguida os solventes com 25 composições diferentes foram injetados no sistema. $O$ teste realizado para caracterizar esses anéis foi o de relaxação de tensões e tanto os anéis de fluorocarbono quanto de fluorosilicone apresentaram boa compatibilidade com estes solventes, sendo que o processo de relaxação não foi afetado nestes sistemas. Enquanto que os anéis 
produzidos com borracha nitrílica durante o contato com os solventes apresentou dissolução de material da borracha nitrílica em decorrência da interação com os solventes.

Kundera e Bochnia [12] fabricaram dois tipos de anéis de vedação utilizando o programa 3D CAD e depois de confeccionados, os anéis foram submetidos a testes de relaxação. Após analisar os resultados, os autores concluíram que a quantidade de carga e o tempo de estabilização (relaxação) são dependentes das propriedades viscoelásticas e da forma geométrica dos anéis, além da tensão e da força de fricção aplicados durante os testes.

Para aumentar a resistência mecânica do fluoroelastômero sob ambientes agressivos quimicamente, muitos trabalhos foram reportados na literatura sobre a incorporação de nanopartículas nesta matriz polimérica. Valsecchi e colaboradores [13] utilizaram um elastômero terpolímero como base e incorporaram argila montmorilonita organomodificada utilizando dois processamentos: no estado fundido e em solução. Os resultados de DRX e das medidas reológicas sugeriram a formação de nanocompósitos esfoliados e delaminados, respectivamente.

Righetti e colaboradores [14] investigaram o comportamento da temperatura de transição vítrea $\left(T_{g}\right)$ em elastômeros reticulados e com diferentes concentrações de negro de fumo. Eles concluíram que a interação entre borracha e carga não influencia na $T_{g}$ desde que a concentração de negro de fumo não ultrapasse $35 \%$.

No Centro de Tecnologia em Borracha, Instituto de Tecnologia da Índia, diversos pesquisadores têm estudado a interação da borracha com argila e com outros polímeros e como essa interação afeta as propriedades físicas e químicas dos polímeros [15 - 18]. Kader e Bhowmick [17] estudaram a correlação entre as propriedades reológicas e a morfologia resultante da separação de fase em blendas de poliacrilato/fluoroelastômero/borracha por meio de ensaios mecânicos. Após analisarem os resultados eles concluíram que o módulo de armazenamento decresce com o aumento do fluoroelastômero na blenda. Porém, o módulo de 
cisalhamento aumenta com o aumento da quantidade de poliacrilato presente na blenda.

Maiti e colaboradores [18] estudaram a degradação térmica de fluoroelastômero incorporados com argila utilizando a análise termogravimétrica em atmosfera de oxigênio e de nitrogênio. Eles concluíram que sob atmosfera de nitrogênio as amostras não vulcanizadas exibem estabilidade térmica maior em relação à análise feita em atmosfera de oxigênio. As análises dos nanocompósitos mostraram que com o aumento da quantidade de argila incorporada há aumento na energia de ativação durante a degradação das amostras.

O grupo de pesquisadores do Departamento de Engenharia Química e do Petróleo, localizado na Universidade de Calgary (Canadá), possuem diversos trabalhos publicados sobre a interação de polímeros com argilas, utilizando o processamento por extrusão no estado fundido [19-23]. Em um dos trabalhos deste grupo foram estudadas as propriedades mecânicas de nanocompósitos a base de fluoroelastômero vulcanizados por peróxidos. As propriedades mecânicas, como alongamento, tensão, módulo de armazenamento apresentaram decréscimo em seus resultados devido a presença de excesso do surfactante na argila não modificada. Porém, como vantagem, houve a redução da taxa de vulcanização dos compostos desenvolvidos [23].

Em outro trabalho deste grupo, Lakshminarayanan et. al [24] compararam o efeito da adição da argila não modificada e da organofílica em matriz de fluoroelastômero. Os compostos foram preparados com diferentes quantidades de argila e foram caracterizados por DRX, reologia e microscopia eletrônica de transmissão. Um dos compósitos foi preparado com a argila organofílica Cloisite 15A e após a análise dos resultados mecânicos foi relatado o aumento do módulo deste compósito, indicando boa dispersão da argila na matriz, e também o aumento do reforço quando este compósito foi comparado com os compósitos feitos com argila não modificada. Este aumento de reforço foi atribuído à redução da tensão superficial da argila organofílica pela presença do seu surfactante. 


\subsection{Nanopartícula POSS}

O silsesquioxano oligomérico poliédrico ou poliedro oligomérico silsesquioxano (Polyhedral oligomeric silsesquioxanes, POSS, FIGURA 1) é um composto híbrido de moléculas de silicone do tipo gaiola compreendidas de átomos de silício ligados em átomos de oxigênio. Sua estrutura é $\left(\mathrm{RSiO}_{3 / 2}\right) \mathrm{n}$ sendo $\mathrm{R}$ um grupo funcional, que é responsável por sua solubilidade em solventes orgânicos e por sua polimerização por meio de técnicas convencionais de polimerização.

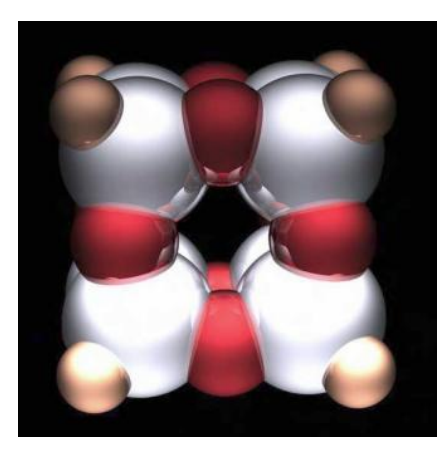

FIGURA 1 - Representação do POSS $®$ Octahíbrido (SH 1311), o modelo de gaiola com hidrogênio nos cantos [25].

As partículas de POSS possuem tamanho entre 1 e $3 \mathrm{~nm}$ de diâmetro e são consideradas as de menor tamanho do grupo dos silicatos. Mas ao contrário da sílica, cada molécula de POSS pode conter diferentes substituintes orgânicos que auxiliam na compatibilização desta nanopartícula com polímeros e também auxiliam no controle da mobilidade da cadeia polimérica. A ligação com o polímero pode ser feita pela copolimerização $[26,27]$ deste composto com um ou mais grupos $\mathrm{R}$ ou pela enxertia do POSS em outra cadeia polimérica [28, 29].

O POSS incorporado em um polímero resulta numa nanoestrutura híbrida orgânica - inorgânica e causa algumas mudanças nas propriedades do fluoroelastômero. As cadeias de POSS atuam como fibras de reforço em nanoescala, melhorando as propriedades mecânicas, densidade (peso leve) e temperatura de uso, devido ao seu tamanho em escala nano e sua relação com 
as dimensões do polímero. Algumas destas alterações provocadas pela adição de nanopartículas de POSS em fluoroelastômero são: a formação de ligações cruzadas na estrutura polimérica, melhorando a propriedade mecânica (resistência à tração e alongamento) da matriz polimérica; a viscosidade do polímero pode ser alterada, porém não o suficiente para interferir em suas propriedades; a permeabilidade pode ser reduzida, pois, o POSS atua como uma carga não permeável e quando está ligado ao elastômero é formada uma estrutura com partes que serão e outras que não serão intumescidas.

O POSS tem diferentes aplicações, como aditivo em polímero, reforço mecânico e retardante de chama. Trabalhos reportados na literatura demonstraram que a incorporação de pouca quantidade do POSS na rede polimérica melhorou significantemente as propriedades mecânicas do elastômero [30, 31] e também suas propriedades térmicas [32]. Lewicki et al. [30], verificaram que a incorporação de pouca quantidade de POSS fisicamente dispersos $(0,1$ a 4\%) em PDMS (polidimetilsiloxano) e após o teste de propriedade mecânica verificaram aumento na resistência à compressão das amostras incorporadas com $3 \%$ de POSS.

A incorporação de POSS em matrizes poliméricas também foi feita para reduzir os valores da constante dielétrica e para aumentar a tenacidade de polímeros em materiais compósitos. Porém para se atingir esse efeito é necessária a incorporação de grandes quantidade de POSS, o que afetaria as propriedades mecânicas e térmicas dos compósitos. Para minimizar o efeito negativo nestas propriedades Jiao e colaboradores [33] estudaram a incorporação de POSS e de sílica mesoporosa em matriz de epóxi. A utilização da sílica foi para diminuir o espaço vazio na matriz, pois assim diminuiria a constante dielétrica sem afetar as propriedades mecânicas, possibilitando a utilização de menores quantidades de POSS. Após analisarem os resultados de DRX, de infravermelho e de TEM, os pesquisadores concluíram que a incorporação simultânea das nanopartículas de POSS-sílica melhoraram as propriedades térmicas e mecânicas devido à forte interação superficial e também pela distribuição homogênea das partículas na matriz de epóxi. 
Pan e colaboradores [31] estudaram a incorporação de POSS em diferentes tipos de PDMS (polidimetilsiloxano), sendo que para o PDMS com terminação silano foi feita a incorporação por mistura física e para o PDMS com terminação vinil foi feita a incorporação química. Os compósitos contendo $2 \% \mathrm{e}$ $5 \%$ de POSS foram submetidos a ensaios mecânicos e constatou-se que tanto o módulo quanto a elongação destes compósitos foram muito reduzidos quando comparados ao PDMS não modificados; eles concluíram que ocorre agregação do POSS ou interferência com a cadeia de PDMS que foi formada.

Liu et al., [32] estudaram a incorporação por métodos químico e físico de quatro tipos diferentes de POSS em resinas de metilsilicone que são utilizadas para aplicações em alta temperatura devido à sua excelente estabilidade térmica. A amostra com a incorporação de $5 \%$ de POSS (triSilanolsobutil) apresentou melhora na propriedade térmica do nanocompósito em relação ao PDMS não modificado.

A incorporação do POSS em matrizes poliméricas pode ser feita por diferentes processos, como a mistura física sob agitação e em alguns casos o uso de solvente para dissolver o POSS e favorecer a dispersão da nanosílica [30, 31]. Outro processo utilizado é o casting que consiste em dissolver o POSS e a matriz polimérica em um solvente compatível a ambos e após a evaporação do solvente obtém-se o compósito (geralmente na forma de filme).

Yang e colaboradores sintetizaram nanocompósitos híbridos orgânicoinorgânico de poliestireno com silsesquioxano oligomérico octavinil-poliédrico (POSS) pelo método de polimerização via radical livre. De acordo com os resultados de análise térmica as temperaturas de transição vítrea e de decomposição aumentam com o aumento na quantidade de POSS. Este fato confirmou que a incorporação do POSS em uma matriz polimérica é uma eficiente maneira de melhorar a estabilidade térmica dos materiais poliméricos [34].

Chen e Shimizu [35] estudaram a funcionalização de nanotubos de carbono com POSS e utilizaram o método de casting para obtenção do polímero 
funcionalizado. Neste trabalho eles utilizaram clorofórmio como solvente para processar todos os reagentes.

Hayakawa e colaboradores [36] realizaram a incoporação do POSS no polímero em solução pelo método casting para obtenção de microestruturas ordenadas híbridas (orgânico-inorgânico).

Uma das principais vantagens do nanocompósito é a combinação da grande área superficial gerada pela nanopartícula inorgância e pela matriz polimérica que permite a melhora nas propriedades mecânicas como tensão, tração e módulo. A segunda maior vantagem é a propriedade de barreira a gases que o nanocompósito possibilita. A impermeabilidade da fase inorgânica força 0 gás a um caminho tortuoso para a permeação através do nanocompósito. A permeabilidade a gases pode ser reduzida entre 50 a 500 vezes com pouca carga de nanopartículas inorgânicas.

Männle et al. [37] pesquisaram a aplicação de revestimento de POSS funcionalizado atuando como barreira a gases e caracterizaram pelas taxas de emissão dos gases hélio e oxigênio para aplicação na indústria de embalagens.

Xiao e colaboradores [38] sintetizaram composto híbrido de epóxi POSS e obtiveram um material com alta densidade de reticulação. Após caracterização por análise térmica (TG e DSC) confirmaram a melhora na estabilidade térmica dos compostos híbridos em relação ao polímero puro. As propriedades mecânicas foram avaliadas por DMA (análise mecânico-dinâmica) a 30 e $200^{\circ} \mathrm{C}$ para analisar a dependência destes compostos com a temperatura e concluíram que o módulo de armazenamento não é dependente da temperatura, o que possibilitaria a aplicação deste material em ambientes com variação de temperatura.

Pesquisadores do grupo de pesquisa da Universidade de Massachusetts Amherst desenvolveram nanocompósitos baseados em poliolefinas e POSS e estudaram a interação dos domínios inorgânicos em escala 
nanométrica com a matriz polimérica. Waddon e Coughlin estudaram a estrutura cristalina e a morfologia do POSS por difração de raios X (DRX) e microscopia eletrônica de transmissão (MET). O POSS pode ser considerado como esferas de formato cristalográfico hexagonal e possuem dimensões laterais da ordem de poucos micrômetros e espessura em torno de mil angstrom [39].

Em outros trabalhos, Waddon e colaboradores estudaram POSS com polietileno e determinaram que o compósito no estado fundido pode conter domínios cristalinos de PE e de POSS e que o grau de cristalização do POSS e sua nanoestrutura formada são altamente dependente da história térmica e do tipo de processamento à qual o compósito foi submetido [40, 41].

A aplicação de nanocompósito como membranas para célula a combustível foi reportada por Pan e colaboradores [42]. Os autores sintetizaram poliimida sulfonada contendo benzimidazol com diferentes graus de sulfonação e incoporaram POSS (contendo grupo éter glicidil) para obtenção de membranas trocadoras de prótons. As propriedades térmicas, mecânicas e de capacidade de troca iônica foram avaliadas e os pesquisadores concluíram que as membranas reticuladas obtiveram melhores resultados de propriedades mecânicas e de estabilidade dimensional e também boa capacidade de troca protônica em relação à membrana produzida com polímero puro.

\subsection{Nanopartícula argila}

A definição clássica designa argila como um material natural, terroso, de granulação fina que quando umedecido com água apresenta plasticidade. Os minerais constituintes das argilas são os argilominerais que possuem estrutura em camadas constituídas por folhas contínuas formadas por tetraedros de silício (ou alumínio) e oxigênio, e folhas formadas por octaedros de alumínio (magnésio ou ferro) e oxigênio e hidroxilas [43, 44]. A seguir a classificação mais comum das argilas:

$\checkmark$ Caulins

$\checkmark$ Argilas plásticas para cerâmica branca 
$\checkmark$ Argilas refratárias

$\checkmark$ Bentonitas

$\checkmark$ Terras fuller

$\checkmark$ Diversas

A classificação das argilas é diferente da classificação dos argilominerais que a constituem. A classificação simplificada dos argilominerais é:

I. Não cristalina

II. Cristalina: duas camadas (1:1), três camadas (2:1), camadas mistas e tipos estruturais em cadeia.

Os grupos de argilomirais, as espécies mineralógicas e suas respectivas composições químicas apresentam variações em propriedades causadas pelas substituições isomórficas e cátions trocáveis. Neste trabalho foi utilizada a argila bentonita cujo principal argilomineral é a montmorilonita ou esmectita (FIG. 2) composta além de silício, por alumínio, magnésio, ferro e algumas vezes cálcio e sódio.

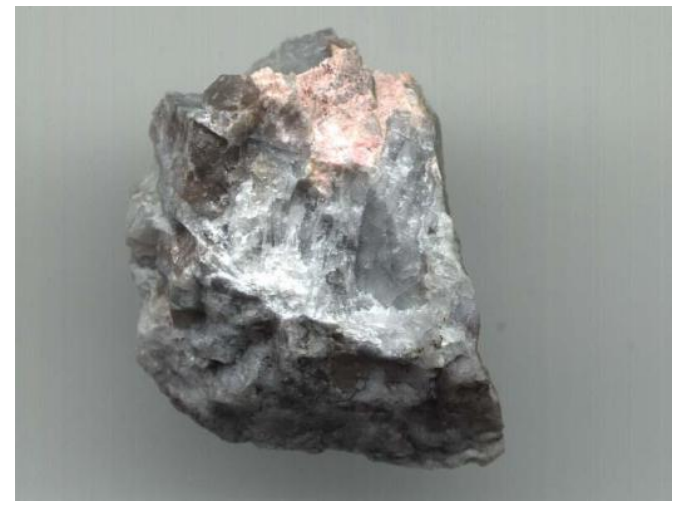

FIGURA 2 - Imagem da argila montmorilonita [45].

As bentonitas podem ser classificadas como as que incham e as que não incham. 
> Bentonitas que incham: sua propriedade específica é de inchar até vinte vezes o volume da argila seca, quando imersas em água; o sódio é o cátion trocável predominante nesta argila (argila sódica).

Bentonitas que não incham: os cátions trocáveis são o cálcio e o magnésio. A troca do sódio por cálcio e magnésio destrói a propriedade da bentonita sódica de inchar. Expostas à umidade atmosférica, as bentonitas cálcicas adsorvem água até uma quantidade correspondente a três camadas moleculares; as partículas se depositam (se precipitam ou floculam) rapidamente quando em dispersões aquosas.

As argilas organofílicas são hidrofóbicas, diferentemente das sódicas que são hidrofílicas. Os sais quaternários de amônio são os responsáveis pela transformação da argila esmectítica sódicas em organofílica, pois eles introduzem hidrofobicidade. Os sais utilizados na modificação possuem um ou dois grupos de hidrocarbonetos de cadeia longa (derivados geralmente de ácidos graxos) ligados diretamente a um átomo de nitrogênio onde se situa a parte catiônica da molécula. Ao adicionar esses sais às dispersões aquosas de argila esmectíticas, esses cátions orgânicos substituem os cátions de sódio que são facilmente trocáveis; assim, os cátions quaternários de amônio, com longas cadeias de hidrocarbonetos livres se acomodam entre as camadas 2:1 do argilomineral, tornando-a organofílica.

A montmorilonita pertence ao grupo dos filossilicatos $2: 1$ que é constituído por duas folhas de silicato tetraédricas com uma folha central octaédrica e unidas entre si por átomos de oxigênios comuns às folhas (FIG. 3). A fórmula estrutural deste argilomineral é $\mathrm{M}_{\mathrm{x}}\left(\mathrm{Al}_{4}-\mathrm{XMg}_{\mathrm{x}}\right) \mathrm{Si}_{8} \mathrm{O}_{20}(\mathrm{OH})_{4}$, possui partículas de pequeno diâmetro aproximadamente $100 \mathrm{~nm}$ e extremamente finas (de $2 \mu \mathrm{m}$ a 0,1 $\mu \mathrm{m}$ ). Estas partículas possuem formato de placas ou lâminas, sua espessura pode chegar até $1 \mathrm{~nm}$ e as dimensões laterais podem variar de $30 \mathrm{~nm}$ a várias micra, o que resulta em uma elevada razão de aspecto, podendo atingir aproximadamente 1000 [46 - 48]. 


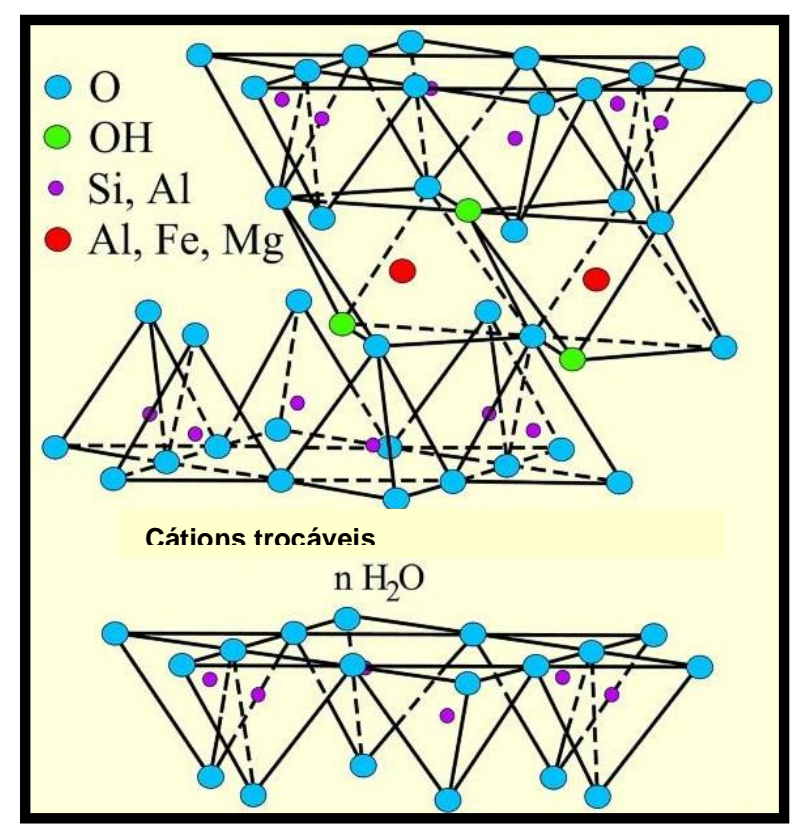

FIGURA 3 - Estrutura cristalográfica octaédrica da argila montmorilonita, adaptado de [49]

A montmorilonita é uma das argilas mais utilizadas como reforço em matrizes poliméricas a nível nanométrico. A forte interação entre o polímero e a argila resulta em fases orgânicas e inorgânicas dispersas em escala nanométrica com diferentes tipos de estrutura do nanocompósito. As estruturas resultantes estão representantadas na FIG. 4 e descritas a seguir $[50,51]$.

Nanocompóstio intercalado: a inserção da argila na matriz polimérica ocorre de forma regular cristalograficamente e com distâncias repetidas de poucos nanômetros.

Nanocompósito esfoliado: as camadas individuais de argilas estão separadas ao longo da matriz por uma distância média que depende da quantidade adicionada de argila. 


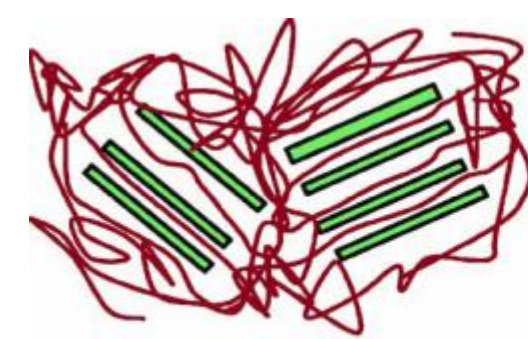

Intercalado

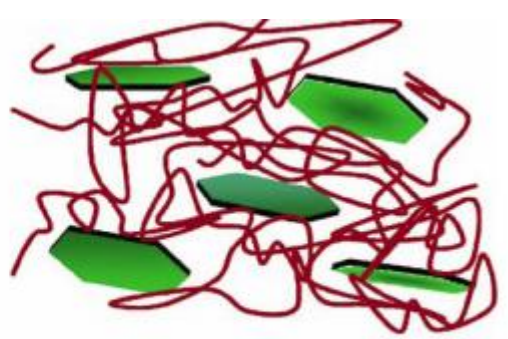

Esfoliado

FIGURA 4 - Representação esquemática dos dois tipos de nanocompósitos de argila-polímero [50].

A incorporação de argila sódica e organofílica em matrizes poliméricas tem sido estudada devido à melhora de propriedades que o nanocompósito apresenta, tais como: aumento de resistência mecânica e térmica, decréscimo na permeabilidade a gases e na inflamabilidade e também, aumento na biodegradação de polímeros biodegradáveis.

Os nanocompósitos podem ser preparados por diferentes métodos: esfoliar as camadas de sílica utilizando um solvente que também seja solúvel para o polímero; intumescer a argila com monômero e iniciar a polimerização in situ com o uso de aquecimento; por radiação ionizante; pela difusão de um iniciador orgânico; e também pelo processo de mistura da argila com um polímero sob força mecânica. Alguns trabalhos reportados na literatura sobre os diferentes tipos de modificação estão descritos a seguir.

Wang e colaboradores [52] utilizaram a radiação gama para enxertar o polímero nas camadas da argila. Antes da irradiação, eles prepararam a montmorilonita pela reação de troca catiônica com solução aquosa de bromo cetiltrimetilamonio (CTAB) e depois enxertaram acrilato de etila nas partículas da argila organofílica.

Moet e Akelah [53] estudaram o processo de enxertia pela polimerização via radical do estireno entre as camadas da argila (montmorinolita) 
e conseguiram identificar pela técnica de microscopia o tamanho das partículas esféricas entre $150-400 \mu \mathrm{m}$.

Laus e colaboradores [54] prepararam argilas enxertadas pelo processo de polimerização em emulsão. A argila funcionalizada foi sintetizada pela troca dos cátions orgânicos da estrutura interna da argila natural com o sal quartenário de (aminometil)estireno. Neste trabalho eles concluíram que as propriedades mecânicas melhoraram parcialmente e que a massa molar da matriz polimérica diminuiu com o aumento da quantidade de argila incorporada.

Algumas patentes da Eastman-Kodak, referentes a nanocompósitos com argilas, têm aplicação como barreira para gases, na fabricação de embalagens para alimentos, medicamentos e bebidas. Estes materiais são formados por poliamida ou poliéster, podendo ou não conter um reagente catalítico para eliminação de oxigênio sequestrado [55].

Um estudo publicado por Gopi e colaboradores [56] verificou a influência da substituição parcial de negro de fumo por Cloisite 15A na composição de borracha de estireno butadieno (SBR), a qual é utilizada na fabricação de pneus. A quantidade de argila vairou de 0 a 10 phr e a de negro de fumo de 0 a 30phr. Os pesquisadores determinaram que 6 phr de cloisite e 25 phr de negro de fumo foram as quantidades que apresentaram melhores resultados de reforço, com diminuição do calor gerado na mistura e melhores propriedades dinâmicas.

Diversos estudos foram publicados referentes à obtenção de nanocompósitos argila - borracha, utilizando diferentes tipos de borracha como matriz polimérica, tais como: borracha natural [57 - 59], estireno-butadieno [6062 ], butadieno-acrilonitrila [63 - 65], entre outros.

A incorporação de argila em fluoroelastômero foi estudada por Mali et al [66]. Os autores estudaram o efeito da incorporação de argila organofílica e de argila sódica em Viton (fluoroelastômero). Após realizarem análises mecânicas e térmicas, eles concluíram a incorporação de até $9 \%$ (em peso) de argila 
organofílica melhora essas propriedades devido à uniformidade da dispersão, formando estrutura intercalada de Viton e argila, o que contribuiu para diminuir a degradação estrutural da matriz polimérica.

\subsection{O processo de enxertia induzida por radiação ionizante}

O processo de enxertia por radiação ionizante é um método muito conhecido e utilizado para a modificação de polímeros pela inclusão de um monômero em uma matriz polimérica. Durante a irradiação o polímero em seu estado excitado, dissipa seu excesso de energia por meio da cisão das ligações da cadeia polimérica, dando origem aos radicais livres. Na FIGURA 5 está representado um mecanismo simplificado da interação da radiação ionizante com o polímero e as consequências causadas na estrutura polimérica.

A interação da radiação com a matéria gera espécies ionizadas e excitadas, as quais produzem os radicais livres. Os radicais livres são átomos ou moléculas que possuem um ou mais elétrons livres (desemparelhados) disponíveis para reagirem quimicamente. Os radicais são formados quando uma ligação covalente da molécula é rompida de forma que uma parte da molécula continua com cada parte dividida. Este processo é reversível, pois a reação de volta representa a combinação de dois radicais que originam uma molécula estável.

Estes radicais são gerados na região amorfa do polímero. Os radicais da fase amorfa podem reagir entre si e com o monômero, no caso de reações de enxertia induzida pela radiação gama. A reação dos radicais produzidos na cadeia polimérica com os radicais produzidos no monômero origina um polímero enxertado. A enxertia gera um copolímero com ligações covalentes, em lugar de simplesmente uma camada de revestimento na matriz polimérica. Este novo polímero apresenta propriedades do monômero enxertado enquanto mantém a maior parte das propriedades da matriz. 


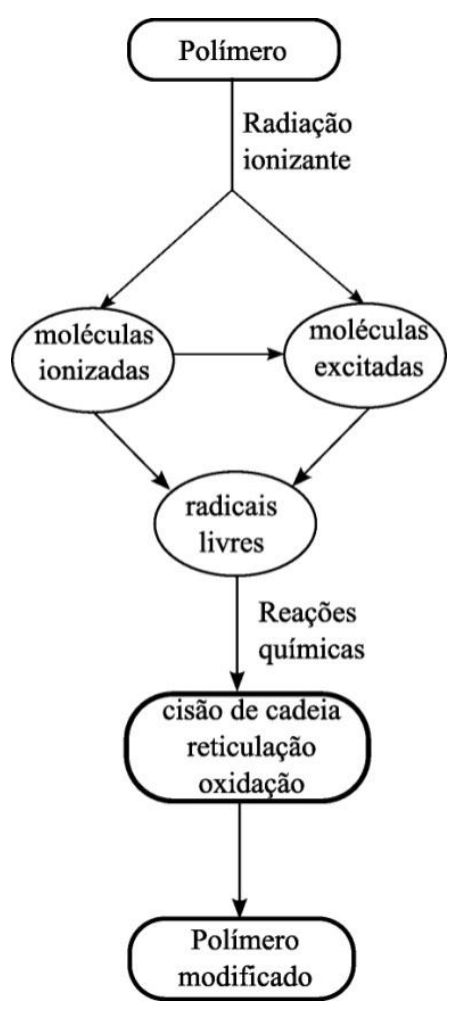

FIGURA 5 - Mecanismo simplificado da interação da radiação ionizante com a matriz polimérica.

O método de enxertia via radiação é o mais eficaz para a introdução do monômero na cadeia polimérica porque as cadeias moleculares podem propagarse através das espécies de radicais que são geradas dentro e fora do filme por irradiação. O mecanismo de fronteira é o que rege a enxertia em polímeros fluorados semicristalinos (estes são pouco solúveis), pois, no início da irradiação a superfície é enxertada e durante o processamento as camadas interiores do polímero serão atingidas uma a uma, conforme a camada anterior torna-se mais solúvel devido à presença do monômero.

Os efeitos da irradiação em polímeros são reticulação, degradação (por oxidação ou por cisão de cadeia) e enxertia [67, 68]. Estes efeitos ocorrem simultaneamente e a predominância de um deles depende de diversos fatores, como: matriz polimérica, dose de radiação, atmosfera e temperatura durante a irradiação, taxa de dose de radiação, entre outros. 
Reticulação: ocorre quando as cadeias poliméricas são interligadas e forma uma rede de ligações cruzadas;

Degradação: a consequência é a diminuição da massa molar do polímero devido à cisão (quebra) de cadeias;

Enxertia: ocorre quando um novo monômero é polimerizado e enxertado na cadeia polimérica. Quando os monômeros são irradiados, a sua polimerização também pode ser iniciada.

Muitos trabalhos na literatura relatam os efeitos da interação da radiação com a cadeia polimérica [69-78]. A cadeia polimérica que possui ligações $\mathrm{C}-\mathrm{H}$ tendem a reticulação como, por exemplo, o polietileno, enquanto que a cadeia que possui átomos halogenados como os polímeros fluorados, tendem a degradação.

Os principais trabalhos sobre os efeitos da radiação em polímeros fluorados foram reportados pelos pesquisadores do Departamento de Energia Nuclear do Japão [69 - 74], liderados pelo professor Yoneho Tabata. Nestes trabalhos, foi confirmado que o principal efeito da interação da radiação com o PTFE é a degradação da cadeia, quando o processamento é feito a temperatura ambiente. A radiação ao interagir com o PTFE ocasiona a quebra das ligações CC e C-F formando os radicais livres, por causa do raio atômico do flúor ser muito grande há o impedimento desses radicais formados de se recombinem entre si. Para transpor essa dificuldade esse grupo de pesquisadores desenvolveu o processo de reticulação por radiação do PTFE no estado fundido, a $330^{\circ} \mathrm{C}$, e sob atmosfera inerte.

A estrutura do PTFE a temperatura ambiente é rígida e cristalina, porém contém uma parte amorfa. Quando o PTFE é aquecido até sua temperatura de fusão é criada outra região amorfa devido à fusão dos cristais existentes em sua estrutura. Devido a essas estruturas amorfas, sem cristais, há o aumento da mobilidade da cadeia polimérica que possibilita a recombinação dos radicais entre $\mathrm{si}$, originando as ligações cruzadas e consequentemente o PTFE reticulado por radiação ionizante [75 - 78]. 
Banik et.al [79] estudaram a interação de monômeros polifuncionais com matriz de fluorcarbono (terpolímero com $68 \%$ de flúor e 1,4\% de hidrogênio) sob radiação de feixe de elétrons. Neste trabalho os pesquisadores demonstraram os efeitos da radiação na cadeia polimérica. Os autores relataram que cadeia de fluoreto de vinila (VF) possui hidrogênio lábil, o qual durante a irradiação foi subtraído da cadeia, gerando radicais livres nos átomos de carbono, estes radicais reagiram com o oxigênio presente no ar ocorrendo a formação de grupos carbonila (FIG 6), e como consequência ocorreu a degradação oxidativa da cadeia polimérica, Porém, estes radicais formados nos átomos de carbono também reagiram entre si formando ligações cruzadas, a reticulação da cadeia (FIG. 7). Além desses efeitos citados também ocorreu a degradação por cisão de cadeia, durante a irradiação houve a quebra das ligações C-F que geraram radicais livres que se recombinaram formando pequenos segmentos de cadeias poliméricas de menor peso molecular (FIG. 8).

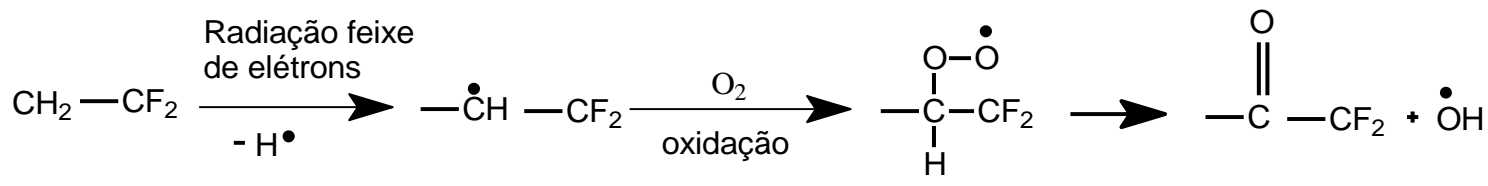

FIGURA 6 - Mecanismo da reação de degradação oxidativa como resultado da Interação da radiação ionizante com o fluoreto de vinilideno (adaptado de 79)

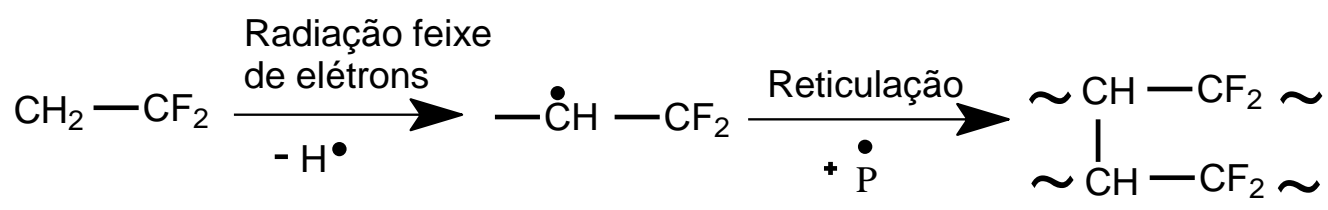

FIGURA 7- Mecanismo da reação de reticulação como resultado da Interação da radiação ionizante com o fluoreto de vinilideno (adaptado de 79) 


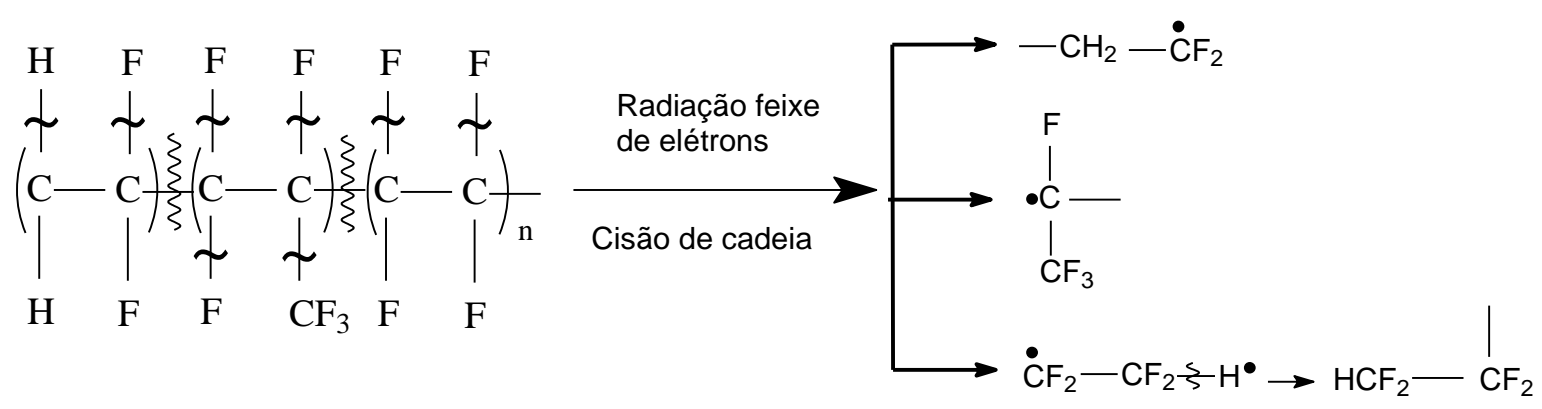

FIGURA 8 - Mecanismo da reação de degradação por cisão de cadeia como resultado da Interação da radiação ionizante com o FKM (adaptado de 79)

O efeito da radiação ionizante no processo de enxertia foi estudado por diversos pesquisadores. Cataldo e colaboradores [80] estudaram a enxertia de Fulereno (C60) em borrachas de poliisopreno utilizando hexano e tolueno como solvente. Esta solução foi submetida à irradiação gama. Eles observaram que o fulereno disponível foi incorporado na matriz polimérica como reticulado.

Peng e colaboradores [81] estudaram a enxertia induzida por radiação gama de anidrido maleico (MAH) e de ácido maleico (MA) para funcionalizar pó ultrafino de borracha de estireno-butadieno. Neste trabalho eles constataram que com o aumento da dose absorvida (4 a $12 \mathrm{kGy}$ e taxa de $40 \mathrm{~Gy} \cdot \mathrm{min}^{-1}$ ) e a diminuição da quantidade de monômero utilizado na solução formaram a melhor condição para um aumento no rendimento de enxertia de ambos os monômeros.

Haldar e Singha [82] pesquisaram a enxertia de acrilato de butila e de metil-metacrilato (MMA) em borracha butílica via feixe de elétrons. Neste trabalho eles analisaram a viscosidade dos polímeros não modificados e dos enxertados e constataram que em altas doses a viscosidade do enxerto diminuiu em relação ao puro, indicando alta degradação do material. 


\subsection{Reação de sulfonação dos filmes enxertados}

Para que a membrana desenvolvida tenha a propriedade de troca iônica é necessário realizar a reação de sulfonação do elastômero enxertado. A reação de sulfonação é definida como uma reação de substituição eletrofílica, na qual o grupamento $\mathrm{SO}_{3} \mathrm{H}$ ligando-se à cadeia do polímero, via ligação química do carbono, ou menos frequentemente, do átomo de nitrogênio de um composto orgânico, originando os ionômeros poliméricos. Os ionômeros são definidos como compostos macromoleculares contendo grupamentos sulfônicos.

De acordo com a literatura existem diferentes processos para se alcançar um bom grau de sulfonação em polímeros. Além da condutividade esta reação pode aumentar ou inserir a propriedade de hidrofilicidade no polímero. Um dos métodos reportados é fazer uma solução de anidrido acético com ácido sulfúrico para formar o agente de sulfonação sulfato de acetila e também o ácido acético como produto. O polímero é então imerso no agente de sulfonação e depois lavado com água até pH constante [67, 68].

Outro método consiste em imergir a membrana enxertada em uma solução de ácido clorosulfônico em 1,2-dicloroetano a temperatura ambiente em diferentes tempos de reação até que se obtenha uma membrana com alta capacidade de troca iônica e que mantenha sua integridade física, química e mecânica [83 - 85].

\subsection{Membranas de troca iônica}

Membranas trocadoras de íons são muito utilizadas em diversas áreas: microfiltração, osmose, pervaporação e também em processos eletroquímicos. Nestes processos eletroquímcos, as membranas podem atuar como:

a) separadores do analito e catalito, em células eletrolíticas e baterias; 
b) separadores entre o eletrólito e o eletrodo, para evitar corrosão deste último ou evitar adsorção de substâncias indesejáveis ou, ainda, na coleta de substâncias de interesse na sua superfície e proceder a uma fácil remoção;

c) constituintes de eletrodos íon-seletivos;

d) catalisadores em reações orgânicas;

e) carregadores de gases.

Uma das áreas em desenvolvimento das membranas para processos eletroquímicos é o uso em célula a combustível. Pesquisadores trabalharam para obter uma membrana com características similares à Nafion® (produzida pela DuPont), que é o estado da arte. Para atuar na célula a combustível a membrana tem que ter como principais características: estabilidade eletroquímica, resistência química e mecânica e alta condutividade iônica.

Grupos na Inglaterra [86, 87], Itália [88, 89] e Finlândia [90] investigaram membranas à base de: fluoropolímeros como ETFE (polietileno- alt tetrafluoroetileno) e PTFE (politetrafluoroetileno); de poliolefinas como PP (polipropileno) e PE (polietileno); PSF (polisulfona); e outras aplicadas em célula a combustível.

Um dos principais grupos de pesquisa em membrana polimérica de troca iônica desenvolvida pelo método da enxertia induzida por radiação ionizante é o Instituto Paul Scherrer na Suíça. Eles trabalharam com membranas fluoradas à base de ETFE [91] e FEP (poli(tetrafluoretileno - co - hexafluoropropileno)) [92] para uso em célula a combustível.

No Brasil alguns grupos trabalham na área de célula a combustível pesquisando diferentes tipos de membranas de troca iônica. Geraldes e colaboradores estudaram os efeitos da pós-radiação em membranas fluoradas, à base de ETFE modificados pelo processo de enxertia induzida por radiação gama. [85]. 
Pesquisadores do Instituto de Química de São Carlos (USP) há muitos anos desenvolvem trabalhos na área de eletrocatalisadores com o intuito de obter catalisadores feitos à base de liga de platina com outros metais e que mantenham o mesmo rendimento. Um dos estudos [93] deste grupo foi um teste de envelhecimento em membranas Nafion com espessuras diferentes. Este trabalho avaliou também o efeito de diferentes condições (pressão, temperatura e umidificação dos gases) durante a operação de uma célula a combustível unitária.

O trabalho mais recente deste grupo, reportado por Hassan et al. [94] foi a modificação do eletrodo anodo de platina modificada com carbeto de tungstênio (WC) para aplicação em célula a combustível. Os pesquisadores depositaram platina no catalisador carbeto-tungstênio (Pt-WC) pelo método de redução em ácido fórmico e compararam os resultados com o eletrodo formado pela deposição de carbono em catalisador de platina-tungstênio (C-PtW). Após testes eletroquímicos eles concluíram que Pt-WC apresentou maior atividade eletroquímica de oxidação de hidrogênio do que o eletrodo C-PtW.

No Instituto de Química da Universidade de São Paulo, o pesquisador Kawano e colaboradores estudaram a membrana Nafion®. Um de seus trabalhos [95] foi o estudo da decomposição térmica da Nafion® na forma ácida e da membrana substituída por cátions mono-valentes e bi-valentes, eles relataram que a estabilidade térmica, o resíduo e a quantidade de água na membrana dependem do raio iônico para a troca catiônica e os efeitos destes cátions foram analisados por intumescimento, espectroscopia vibracional e estabilidade térmica. 


\section{OBJETIVO E ORIGINALIDADE DO TEMA}

O objetivo deste trabalho foi desenvolver e caracterizar uma membrana polimérica híbrida, por meio da incorporação de nanopartículas inorgânicas em matriz de fluoroelastômero. O filme de FKM foi submetido à reação de enxertia induzida por radiação, seguida de sulfonação, para obtenção de uma membrana trocadora de prótons.

\subsection{Originalidade do tema}

O desenvolvimento de membranas de troca iônica à base de fluoroelastômero tem como vantagem a mobilidade da cadeia polimérica devido a ausência de cristais. Esta ausência de cristais facilita a incorporação de nanopartículas e a enxertia de monômeros funcionais. A incorporação de nanopartículas inorgânicas por mistura em cilindro prevê melhor dispersão das nanopartículas, o que possibilita a obtenção de um filme com enxertos distribuídos homogeneamente.

O método de desenvolvimento desta membrana à base de fluoroelastômero que incluiu as etapas de incorporação de nanopartículas inorgânicas e do processo de enxertia via radiação ionizante seguida de sulfonação é inédito na literatura até esse momento. 


\section{PARTE EXPERIMENTAL}

\subsection{Matérias primas e reagentes}

As matérias primas e reagentes utilizados neste trabalho estão descritos a seguir. Como carga inorgânica foram utilizadas quatro nanopartículas com diferentes estruturas moleculares.

As nanopartículas POSS com diferentes configurações foram adquiridadas da Hybrid Plastics Lt (FIG.9-11) [25]:

1. POSS OL1159 - POSS octaciclohexenildimetilsilil - $\mathrm{C}_{80} \mathrm{H}_{152} \mathrm{O}_{20} \mathrm{Si}_{16}$ CAS no 136849-03-1. Esta nanopartícula possui peso molecular $1883,42 \mathrm{~g} \mathrm{~mol}^{-1} \mathrm{e}$ ponto de fusão entre $67-71^{\circ} \mathrm{C}$.<smiles>[R]O[Si]12O[Si]3([R])O[Si]4([R])O[Si]([R])([R])O[Si]5([R])O[Si]([R])(O3)O[Si]([R9])(O[Si]([R])(O5)O[Si]([R])(O4)O1)O2</smiles>

FIGURA 9 - Estrutura molecular do POSS OL1159 
2. POSS OL1160 - Octavinilpentaciclo-octasiloxano - $\mathrm{C}_{16} \mathrm{H}_{24} \mathrm{O}_{12} \mathrm{Si}_{8}-\mathrm{CAS} \mathrm{n}^{\circ}$ 69655-76-1. Esta nanopartícula possui peso molecular 633,05 g.mol ${ }^{-1}$, ponto de fusão acima de $350{ }^{\circ} \mathrm{C}$ e é indicado como agente de reticulação pelo fabricante.<smiles>[R][Si]12O[Si]3([R])O[Si]4([R])O[Si]([R])(O1)O[Si]1([R])O[Si]([R])(O2)O[Si]([R])(O3)O[Si]([R])(O4)O1</smiles>

FIGURA 10 - Estrutura molecular do POSS OL1160

3. OL1163 - POSS octavinildimetilsilil $-\mathrm{C}_{32} \mathrm{H}_{72} \mathrm{O}_{20} \mathrm{Si}_{16}$. Esta nanopartícula possui peso molecular 1226,27 g. $\mathrm{mol}^{-1}$ e é indicado pelo fabricante como agende de reticulação para borracha.

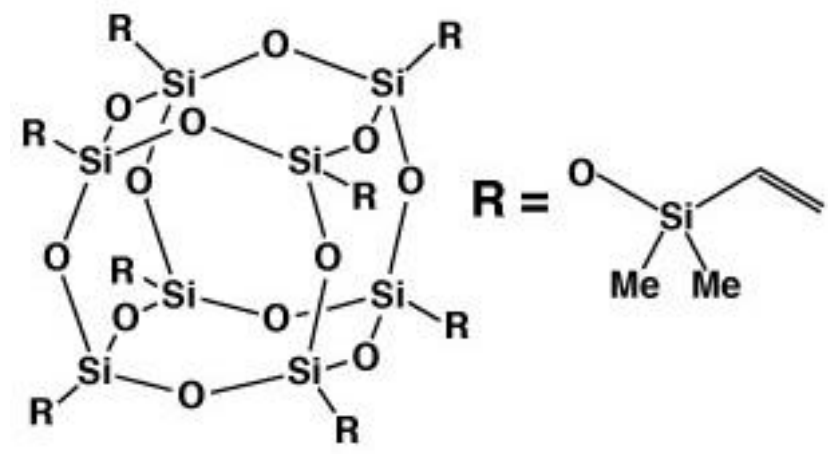

FIGURA 11 - Estrutura molecular do POSS OL1163 
A nanopartícula argila - Cloisite® 15 A (organofílica) foi fornecida já modificada com sal quartenário de amônio (2M2HT: dimetil, cauda dehidrogenada, sendo que HT com composição: $\sim 65 \%$ C18; 30\% C16; 5\% C14) pela Southern Clay. Sua fórmula estrutural é $(\mathrm{Na}, \mathrm{Ca})_{0,33}(\mathrm{Al}, \mathrm{Mg})_{2} \mathrm{Si}_{4} \mathrm{O}_{10}(\mathrm{OH})_{2} \cdot \mathrm{nH}_{2} \mathrm{O}$ e sua estrutura cristalográfica é do tipo octaédrica. De acordo com o fabricante a argila possui 125 meq. $100 \mathrm{~g}^{-1}$ de surfactante.

O composto do elastômero Viton F605C (DuPont®) foi adquirido da empresa Croslin Compostos de Borracha Ltda. Este elastômero é um terpolímero formado por hexafluoropropileno (HFP), fluoreto de vinilideno $\left(\mathrm{VF}_{2}\right)$ e tetrafluoroetileno (TFE) (FIG. 12), com aproximadamente $70 \%$ de flúor em sua composição. A formulação básica utilizada para confecção deste composto foi feita baseada em partes por cem (phr) de borracha e contem: 6 phr de hidróxido de cálcio $\left(\mathrm{Ca}(\mathrm{OH})_{2}\right), 3$ phr de óxido de magnésio $(\mathrm{MgO}), 30 \mathrm{phr}$ de negro de fumo (N990) e o Bisfenol foi utilizado agente de cura. A densidade desse material é $1,90 \mathrm{~g} \cdot \mathrm{cm}^{-3}$, a visosidade Mooney é $60 \mathrm{ML} 1+10$ a $121^{\circ} \mathrm{C}$ e dureza de 70 Shore A.

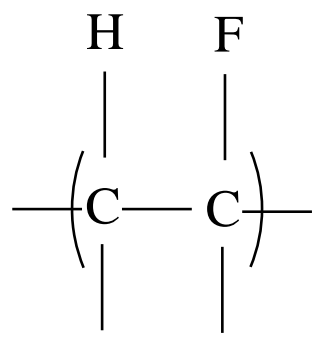

$\mathrm{H} \quad \mathrm{F} \quad \mathrm{VF}_{2}$

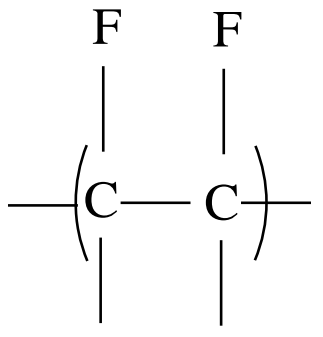

$\mathrm{CF}_{3}$

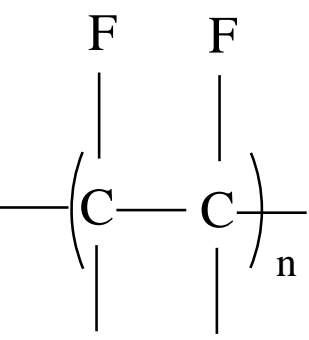

F F TFE

FIGURA 12 - Estrutura molecular do fluoroelastômero terpolímero formado por, $\mathrm{VF}_{2}$, HFP e TFE.

O monômero estireno 99,7\% foi adquirido da Maxepoxi Industrial e Comercial Ltda. com até 25ppm de inibidor 4-tert-butilcateco. 
Os solventes grau PA tolueno, acetona e metiletilcetona (MEK) foram adquiridos de diversos fornecedores.

\subsection{Metodologia}

\subsubsection{Obtenção dos filmes de FKM incorporados com nanopartícula}

As mantas de borracha incorporadas com as nanopartículas foram preparadas em um misturador de cilindro aberto (Copê), com dois rolos com capacidade para 40kg, segundo norma ASTM D-3182 [96]. Este método foi escolhido por ser o mais comum e amplamente utilizado na indústria de borracha.

Para a obtenção dos nanocompósitos (FKM incorporados com nanopartícula), as nanopartículas foram incorporadas nas seguintes composições em relação ao peso do composto da borracha: 0,5\%; 1\%; e $2 \%$

Após a obtenção de mantas, com $1 \mathrm{~mm}$ de espessura, de elastômeros incorporadas com nanopartículas de argila e de POSS, foram realizados dois procedimentos para preparação dos filmes elastoméricos:

1) As mantas não vulcanizadas foram submetidas à irradiação e em seguida vulcanizadas para obtenção de filmes.

2) As mantas foram vulcanizadas para a obtenção de filmes e posteriormente irradiadas.

\subsubsection{Processamento por irradiação}

A irradiação das amostras foi feita no Irradiador Multipropósito de Cobalto-60 localizado no IPEN. As doses às quais o material foi submetido foram de 5, 10 e 20 kGy. Neste trabalho foram testados os três métodos de irradiação descritos a seguir e todos foram processados em duas temperaturas diferentes: $25^{\circ} \mathrm{C}$ e $-78^{\circ} \mathrm{C}$, conforme procedimentos desenvolvidos no laboratório de polímeros do CQMA (Centro de Química e Meio Ambiente, IPEN) [97]. 
> Método simultâneo: o polímero fluorado foi adicionado à solução de enxertia (sob atmosfera inerte) e ambos submetidos à irradiação ionizante.

> Método da pré-irradiação: neste método o elastômero foi mantido em atmosfera inerte durante a irradiação e após este processo a solução de enxertia foi adicionada ao polímero. A reação de enxertia foi realizada em diferentes temperaturas.

> Método da peroxidação: o elastômero foi mantido em oxigênio durante a irradiação e após este processo o polímero foi adicionado à solução de enxertia, a qual também foi realizada em diferentes temperaturas.

\subsubsection{Processo de enxertia induzida por radiação gama, seguida de sulfonação}

Depois da obtenção dos nanocompósitos (elastômeros incorporados com nanopartícula), o material foi submetido ao processo de enxertia induzida por radiação ionizante.

A preparação das amostras para esta etapa foi a mesma independente do procedimento utilizado para a obtenção dos filmes de nancompósitos. As amostras foram cortadas em triplicatas, pesadas (massa inicial, $\mathrm{m}_{\mathrm{i}}$ ) e colocadas em um frasco de vidro. Para as soluções de enxertia foram utilizadas a seguintes composições:

$\checkmark$ Monômero estireno e solvente tolueno, nas proporções 4:1 e 1:1, respectivamente;

$\checkmark$ Monômero estireno e solvente MEK, nas proporções 4:1 e 1:1, respectivamente;

$\checkmark$ Solução contendo $40 \%$ monômero estireno e $60 \%$ isopropanol em volume e adição de $1 \% 0,2 \mathrm{M} \mathrm{H}_{2} \mathrm{SO}_{4}$ (ácido sulfúrico);

$\checkmark$ Monômero estireno purificado e solvente MEK, nas proporções 4:1 e $1: 1$, respectivamente.

Após finalizado o processo de enxertia, as amostras foram lavadas para remoção do homopolímero formado, secas em estufa e novamente pesadas 
(massa final, $m_{\mathrm{f}}$ ). A equação 1 foi utilizada para o cálculo do grau de enxertia (GE).

$$
G E=\left(\frac{m_{f}-m_{i}}{m_{i}}\right) * 100
$$

eq. 1

Todas as amostras vulcanizadas antes e depois da irradiação, assim como as amostras de borracha não vulcanizada irradiada e não irradiada foram submetidas a reação de enxertia induzida por radiação gama, nos diferentes parâmetros. Abaixo estão descritos os tipos de processamento para obtenção dos filmes de FKM até a reação de enxertia.

1) As mantas não vulcanizadas foram submetidas ao processo de enxertia induzida por radiação gama de acordo com os parâmetros e métodos de irradiação já descritos.

2) As mantas não vulcanizadas foram irradiadas e depois submetidas ao processo de enxertia induzida por radiação gama de acordo com os parâmetros e métodos de irradiação já descritos.

3) As mantas não vulcanizadas foram irradiadas, depois foram vulcanizadas para obtenção de filmes de FKM e posteriormente submetidas ao processo de enxertia induzida por radiação gama.

4) As mantas foram vulcanizadas, depois foram irradiadas e posteriormente submetidas ao processo de enxertia induzida por radiação gama.

Para a obtenção das membranas trocadoras de íons foi necessária a reação de sulfonação nos filmes enxertados. A reação de sulfonação consistiu na imersão dos filmes enxertados em solução de ácido sulfúrico ou de ácido clorosulfônico em diferentes temperaturas e diferentes tempos de reação. Após a sulfonação, os filmes foram lavados com água até pH neutro.

Para a reação de sulfonação foram testados três sistemas, relatados a seguir: 
1. Solução de $2 \mathrm{~mol}_{\text {.L- }}{ }^{1}$ de ácido sulfúrico a $90^{\circ} \mathrm{C}$ por 3,6 e $9 \mathrm{~h}$;

2. Solução de $2 \%$ em volume de ácido clorosulfônico em 1,2dicloroetano a temperatura ambiente por 3, 6 e 9h;

3. Solução de $20 \%$ em volume de ácido clorosulfônico em 1,2dicloroetano a temperatura ambiente por 3, 6 e 9h;

Os filmes expostos a 6 e $9 \mathrm{~h}$ de reação de sulfonação não mantiveram estabilidade dimensional, todos os filmes quebraram e/ou apresentaram rachaduras. Portanto, o tempo de imersão na solução de sulfonação ficou determinado por $3 \mathrm{~h}$.

\subsection{Caracterização}

\subsubsection{Ensaio de tração}

Para realização de ensaio de tração foram confeccionados corpos-deprova a partir dos filmes obtidos por termoprensagem Os corpos-de-prova consistiram de tiras retangulares com as dimensões de $8 \mathrm{~cm}$ de altura, $1 \mathrm{~cm}$ de largura e $0,2 \mathrm{~mm}$ de espessura, foram utilizados 5 corpos de prova de cada amostra para realização deste teste. Os ensaios mecânicos de tensão e alongamento foram realizados no equipamento Texturômetro TA.XT da marca Stable Micro System, com carga de $50 \mathrm{kN}$ e velocidade de $500 \mathrm{~mm} \cdot \mathrm{min}^{-1}$.

\section{Tensão de Ruptura}

Este valor é definido como a força aplicada por unidade de área da seção transversal de um corpo de prova, no momento da ruptura, coforme ASTM D 412 [98].

Alongamento 
Este valor é definido como a diferença em porcentagem entre o tamanho da amostra (distância inicial) até sua ruptura (distância final). $\mathrm{O}$ valor obtido é o alongamento no momento da ruptura [98].

\subsubsection{Dureza}

Os índices numéricos de dureza representam a profundidade da penetração [99]. A dureza é uma das propriedades mais medidas da borracha e o durômetro é o instrumento utilizado. $O$ aparelho empregado foi um durômetro Shore A, marca Instrutemp modelo digital portátil Dp-100, que possui uma agulha de formato tronco cônico. Para esta análise foi confeccionado um molde com dimensões de $6 \mathrm{~cm} \times 3 \mathrm{~cm} \times 3 \mathrm{~cm}$ para obtenção de corpos de prova, de acordo com ASTM D2240.

\subsubsection{Reometria}

Por meio desta técnica, determinaram-se os parâmetros de vulcanização de acordo com ASTM D 2084 [100]. O equipamento utilizado foi o Reômetro Alpha Technologies R100 com frequência de $1,67 \mathrm{~Hz}$, amplitude de oscilação $\pm 3^{\circ}$. Os parâmetros avaliados foram:

$T_{S x}$ - tempo de início da vulcanização;

$\mathrm{MH}$ - torque máximo, que indica o grau de reticulação do composto vulcanizado;

$\mathrm{ML}$ - torque mínimo que representa a viscosidade do composto à temperatura de vulcanização considerada;

$\mathrm{T}_{90}$ - chamado de tempo ótimo de vulcanização, é o tempo necessário para atingir 90 \% do torque máximo e que foi calculado de acordo com a equação 2.

$$
\mathrm{T}_{90}=(\mathrm{MH}-\mathrm{ML}) \times 0,9+\mathrm{ML}
$$

eq. 2

A FIG. 13 representa uma curva típica obtida pela análise reométrica do composto de borracha. 


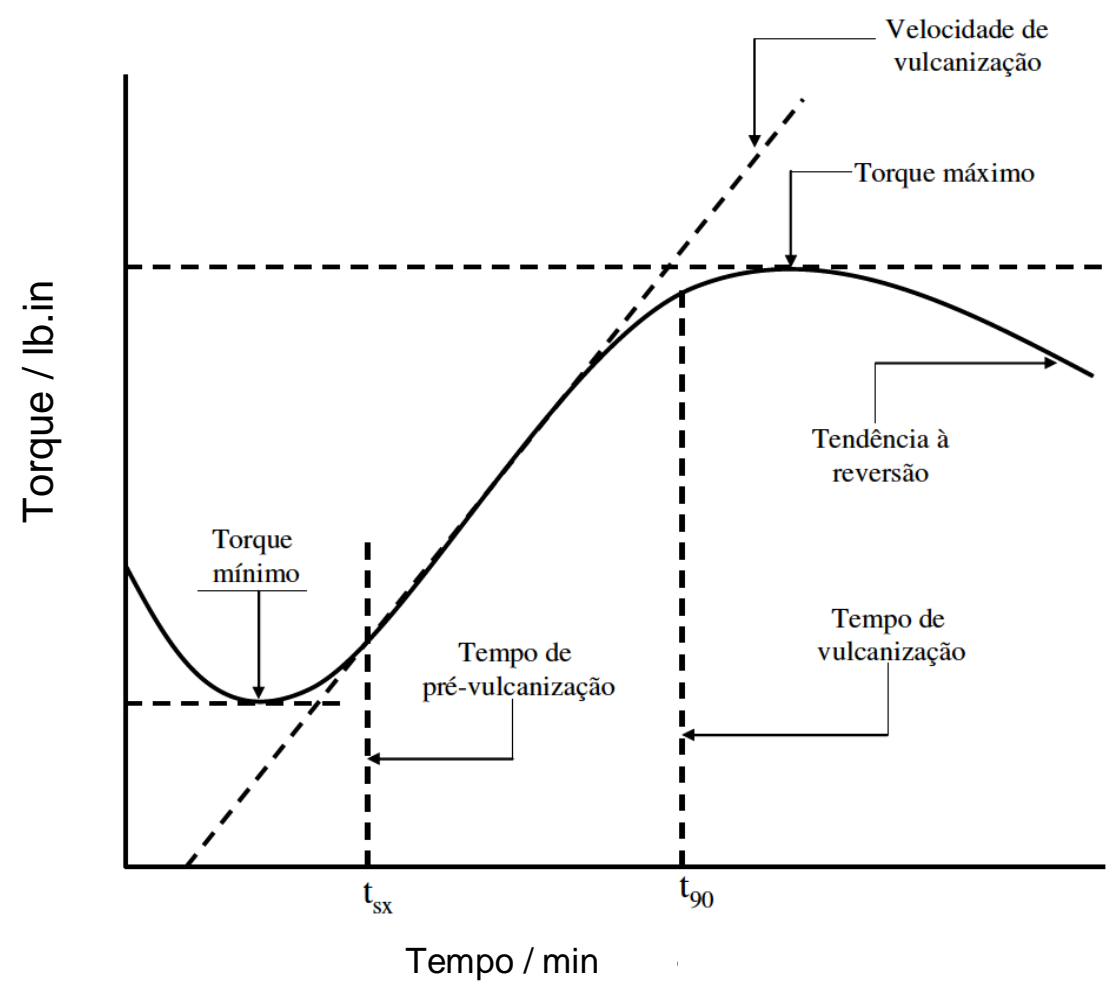

FIGURA 13 - Representação da curva obtida pela análise de reometria, adaptado de $[100]$

\subsection{4 Índice de Intumescimento (Swelling)}

O índice de intumescimento foi determinado pela imersão dos filmes nos solventes tolueno (polar) e MEK (apolar). As amostras (em triplicata) foram pesadas (massa inicial, $\mathrm{m}_{\mathrm{i}}$ ) e imersas no solvente, a partir de então a cada 24 horas foi feita a pesagem destas amostras até que o peso fosse constante (massa final, $m_{f}$ ). Este teste foi realizado de acordo com os procedimentos descritos na ASTM D 3616 [101]. O cálculo deste índice foi realizado por diferença gravimétrica, de acordo com a equação 3.

$$
\%=\left(\frac{m_{f}-m_{i}}{m_{i}}\right) * 100
$$


Os resultados obtidos para o teste de intumescimento em tolueno foram inconclusivos. Como o tolueno não é solvente para FKM, os valores obtidos de intumescimento não mostraram tendência para os efeitos de degradação nem para reticulação. Os resultados obtidos utilizando este solvente estão ilustrados nos apêndices $\mathrm{A}$ e $\mathrm{B}$.

\subsubsection{Intumescimento de Foster}

Para se determinar o intumescimento das argilas foi realizado o teste de intumescimento desenvolvido por Margareth D. Foster [102] que consistiu em adicionar lentamente $1 \mathrm{~g}$ de argila em uma proveta (com capacidade de $100 \mathrm{~mL}$ ) contendo $50 \mathrm{~mL}$ de solvente. Após $24 \mathrm{~h}$ de repouso à temperatura ambiente a argila foi agitada por 5 minutos e deixada em repouso por mais $24 \mathrm{~h}$, depois deste tempo decorrido foi feita a leitura do intumescimento. A medida de intumescimento é representada por concentração $\left(\mathrm{mL} . \mathrm{g}^{-1}\right)$ da argila em relação ao solvente. Para este teste os solventes utilizados foram: água destilada, metiletilcetona e tolueno.

O grupo do Laboratório de Matérias-Primas Particuladas e Sólidos Não Metálicos (LMPSol) da Escola Politécnica da Universidade de São Paulo (EPUSP), baseados em diversos estudos com argilas [103, 104] desenvolveu índices para quantificar o resultado do teste de intumescimento de Foster, conforme a seguir:

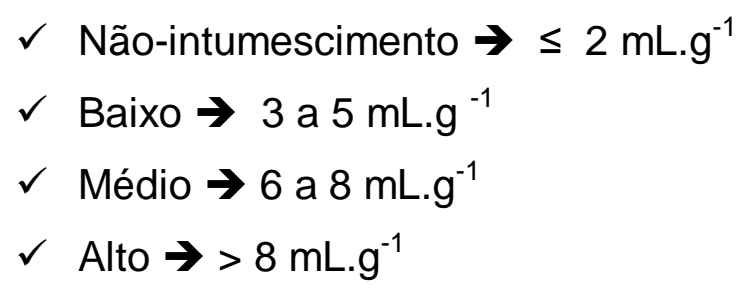

\subsubsection{Termogravimetria (TG)}

As curvas termogravimétricas foram obtidas em um equipamento TGA / SDTA 851 da Mettler-Toledo com termobalança utilizando-se faixa de temperatura de 25 a $700{ }^{\circ} \mathrm{C}$, com razão de aquecimento de $10{ }^{\circ} \mathrm{C} \mathrm{min}^{-1}$ sob atmosfera inerte. 
As amostras foram pesadas entre $4-4,5 \mathrm{mg}$ e acondicionadas em cadinhos de alumina. A aferição deste aparelho foi feita com as amostras de Índio.

O gás nitrogêni utilizado nas análises possuía grau de pureza 99,999\% com nível de oxigênio menor que 1 ppm, da empresa White Martins. Para purga durante a análise foi utilizado o gás nitrogênio com grau de pureza 99,996\% com nível de oxigênio menor que 5 ppm, da empresa White Martins. Ambos com fluxo de $40 \mathrm{~mL} \cdot \mathrm{min}^{-1}$.

\subsubsection{Microscopia eletrônica de varredura (MEV)}

Esta técnica é utilizada para a caracterização de microestruturas em polímeros devido à alta resolução espacial $(0,2 \mathrm{~nm})$ na obtenção de imagens superficiais e internas dos materiais em estudo. O microscópio eletrônico de varredura da marca PHILIPS XR-30 e também o da marca HITACHI Tabletop TM3000 alocados no Centro de Ciência e Tecnologia de Materiais (CCTM) do IPEN-CNEN/SP foram utilizados para analisar a superfície do material.

\subsubsection{Titulometria}

Após a sulfonação foi analisada a capacidade de troca iônica (em inglês IEC, ion exchange capacity) a partir da metodologia de titulação potenciométrica.

Esta análise consistiu em deixar a membrana, obtida após a reação de sulfonação e que está com o pH neutro, imersa em uma solução de cloreto de sódio $(\mathrm{NaCl}) 3 \mathrm{~mol}^{\mathrm{L}} \mathrm{L}^{-1}$ por um período de 15 horas sob agitação constante. Durante este período os prótons $\left(\mathrm{H}^{+}\right)$da membrana sulfonada devem ser trocados pelos íons $\mathrm{Na}^{+}$da solução.

Em seguida a membrana foi retirada da solução ácida. Esta solução ácida foi titulada com uma solução alcalina de concentração conhecida (hidróxido de sódio, $\mathrm{NaOH}$ 0,05 mol..-1 ${ }^{-1}$. A relação entre o volume de $\mathrm{NaOH}\left(\mathrm{V}_{\mathrm{NaOH}}\right)$ consumido na titulação e a massa final da membrana enxertada forneceu a capacidade de troca iônica, conforme a equação 4 , sendo $\mathrm{C}_{\mathrm{NaOH}}$ a concentração 
de hidróxido de sódio e $m_{f}$ a massa final da membrana seca após a reação de enxertia.

$$
\mathrm{IEC}=\frac{\mathrm{V}_{\mathrm{NaOH}} \mathrm{C}_{\mathrm{NaOH}}}{\mathrm{m}_{\mathrm{f}}}
$$

eq. 4

\subsubsection{Difração de Raios X (DRX)}

Esta análise foi realizada em um Difratômetro de raios $X$ Rigaku Miniflex II, $\lambda\left(\right.$ CuK $\alpha-1,54 \AA$ ) na configuração $\theta / \theta$ de $0,5-80^{\circ}$, a $0,05^{\circ} . \mathrm{s}^{-1}$ do Laboratório de Química Supramolecular e Nanotecnologia do Centro de Química e Meio Ambiente do IPEN. A variação do espaço interplanar das matérias primas antes e depois da irradiação foi verificada por esta análise. 
5 RESULTADOS E DISCUSSÃO

\subsection{Irradiação das matérias primas}

A primeira etapa deste trabalho foi submeter todas as matérias primas (elastômero e nanopartículas) à irradiação para verificar as alterações induzidas pela radiação ionizante.

As amostras foram irradiadas sob atmosfera de ar e temperatura ambiente nas doses de 5, 10 e $20 \mathrm{kGy}$. Estas doses baixas foram escolhidas para diminuir o efeito degradativo nos materiais.

\subsubsection{Efeito da radiação ionizante em argila - Cloisite 15A}

O intumescimento da bentonita é em função do cátion trocável (sódio ou cálcio) predominante entre as camadas. No caso do sódio, a argila quando imersa em água pode aumentar várias vezes em relação ao volume da argila seca [105]. Este procedimento teve como objetivo confirmar o caráter hidrofóbico da argila organofílica dispersando-as em três solventes: água, acetona e MEK, seguindo os procedimentos do teste de intumescimento de Foster.

O resultado obtido para o intumescimento em água confirmou o caráter hidrofóbico para a argila Cloisite 15A pela ausência de intumescimento. Este tipo de argila teve o sódio substituído pelos cátions quaternários de alquilamônio, fazendo com que a argila não apresentasse intumescimento ou dispersabilidade em contato com a água (FIGURA 14). A argila permaneceu na superfície da água após $24 \mathrm{~h}$ em repouso e depois de forte agitação por mais $24 \mathrm{~h}$ em repouso, houve uma pequena quantidade de argila dispersa na água, porém a maior quantidade permaneceu na superfície. 

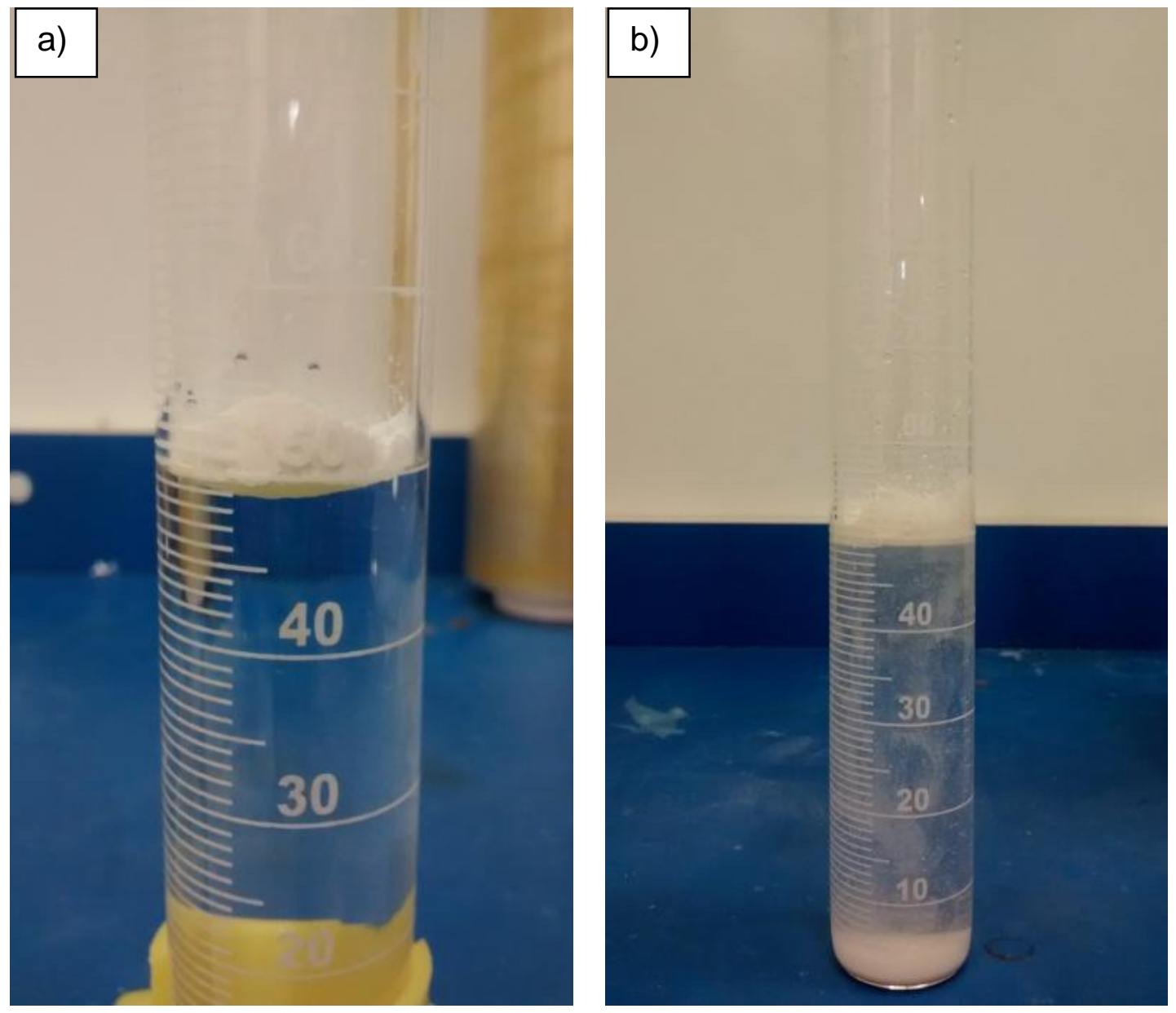

FIGURA 14 - Resultado do intumescimento de Foster para argila Cloisite 15A em água a) após $24 \mathrm{~h}$ e b) após $48 \mathrm{~h}$

Os resultados obtidos para o teste de Intumescimento de Foster em tolueno (FIG. 15) confirmou o caráter apolar da argila organofílica. Após 24h em repouso a argila apresentou alteração de cor (de branco para amarelo) e permaneceu suspensa na superfície do solvente. Após forte agitação e mais 24h em repouso ocorreu a dispersão da argila no solvente tolueno, definindo assim a afinidade da argila organofílica com solvente orgânico. 


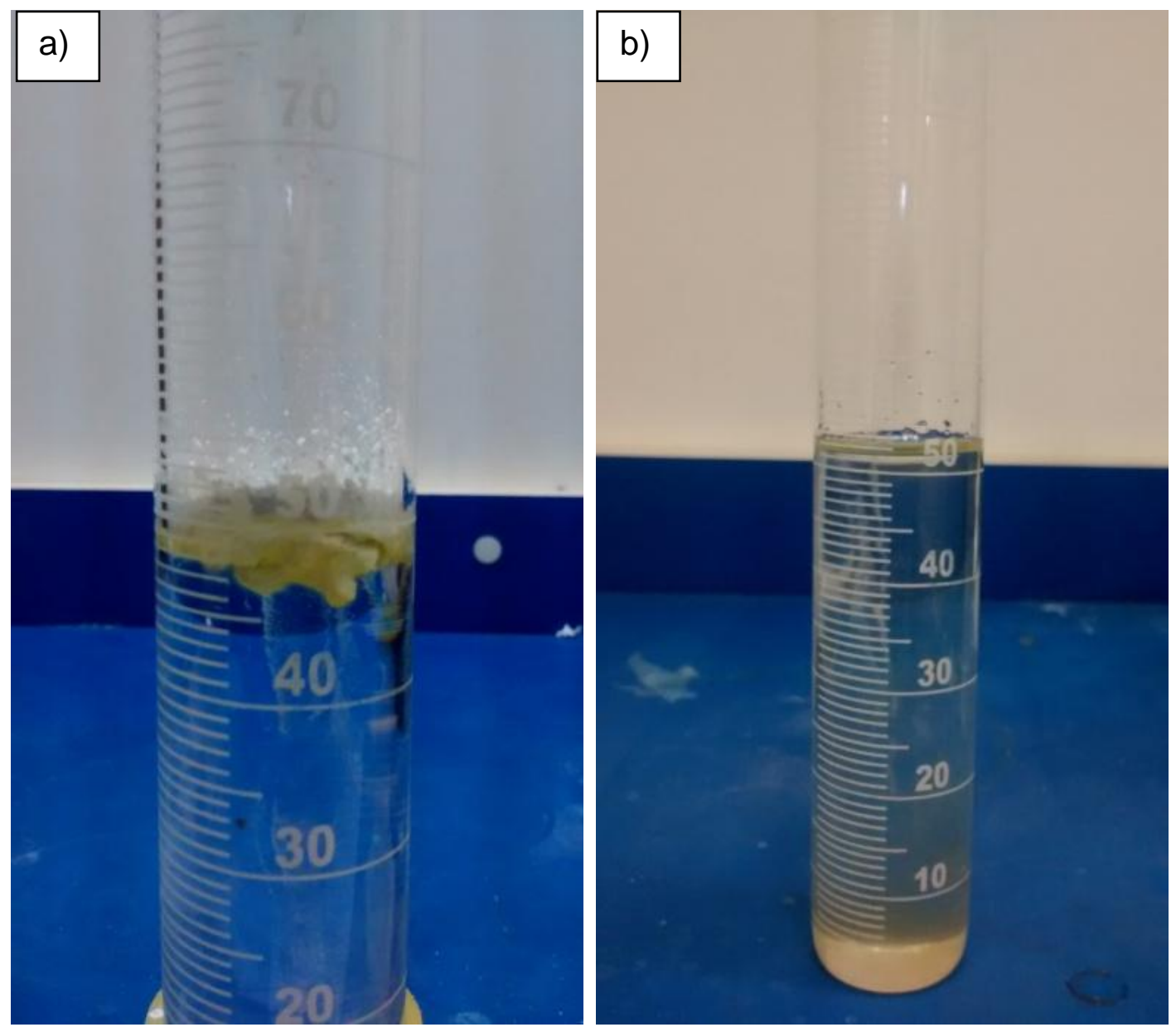

FIGURA 15 - Resultado do intumescimento de Foster para argila em tolueno: a) após $24 \mathrm{~h}$ e b) após $48 \mathrm{~h}$

Os resultados obtidos para o intumescimento em MEK estão ilustrados na FIG. 16. Após $24 \mathrm{~h}$ em repouso verificou-se a dispersão da argila Cloisite 15A no MEK e após 48h houve a argila continuou dispersa porém com a presença de sedimentado. 

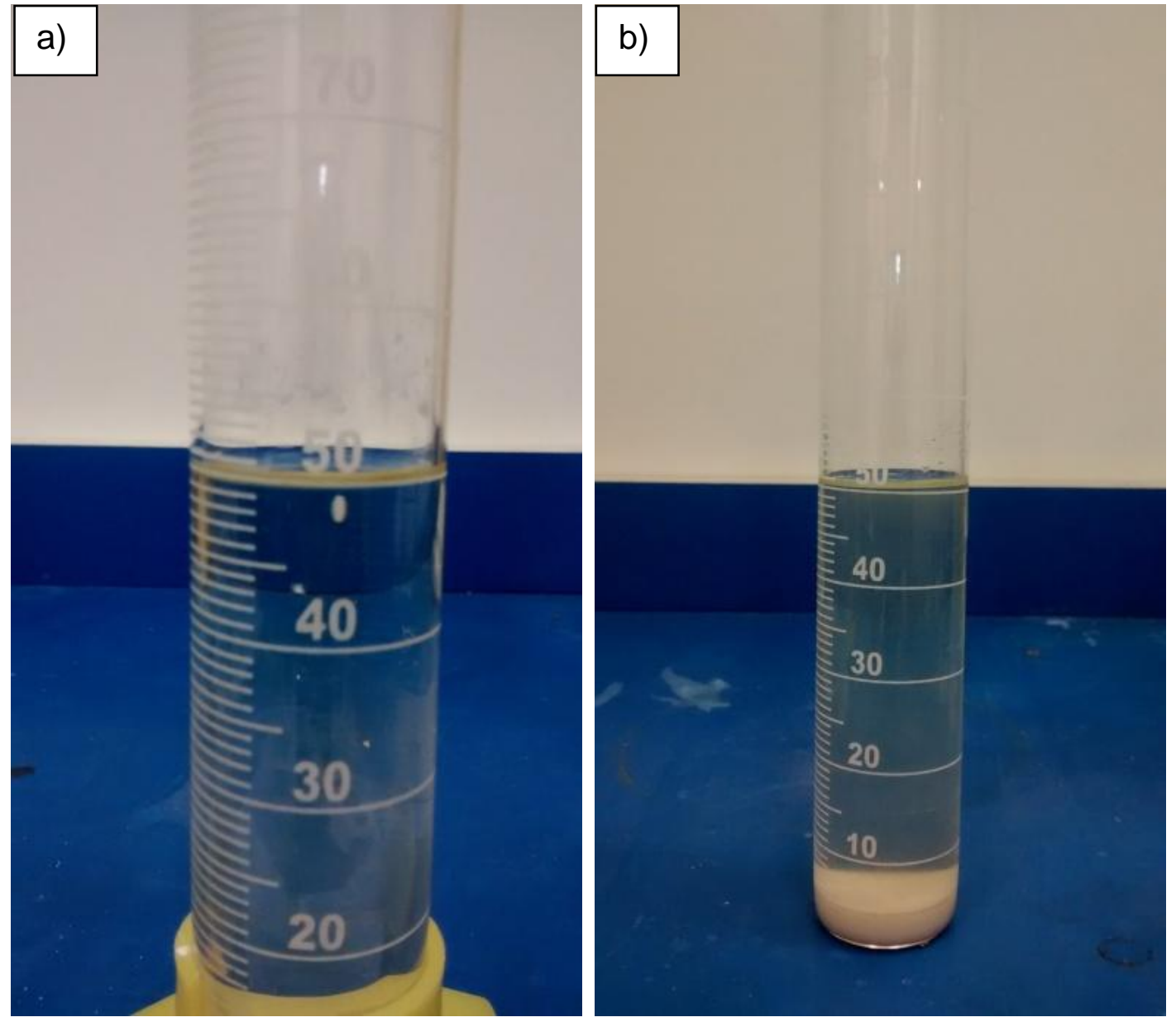

FIGURA 16 - Resultado do intumescimento de Foster para argila em MEK: a) após $24 \mathrm{~h}$ e b) após $48 \mathrm{~h}$

As curvas termogravimétricas obtidas para a argila não irradiada e irradiada estão representadas na FIG. 17. Os perfis de decomposição das amostras mostram que sua estabilidade térmica não foi alterada pela irradiação.

As etapas 3 e 4 referem-se à decomposição dos sais alquil amônio presentes na estrutura da argila [106]. A etapa 5 representa a perda de massa pela desidroxilação das camadas de argila devido a perda de água estrutural [107, 108]. 


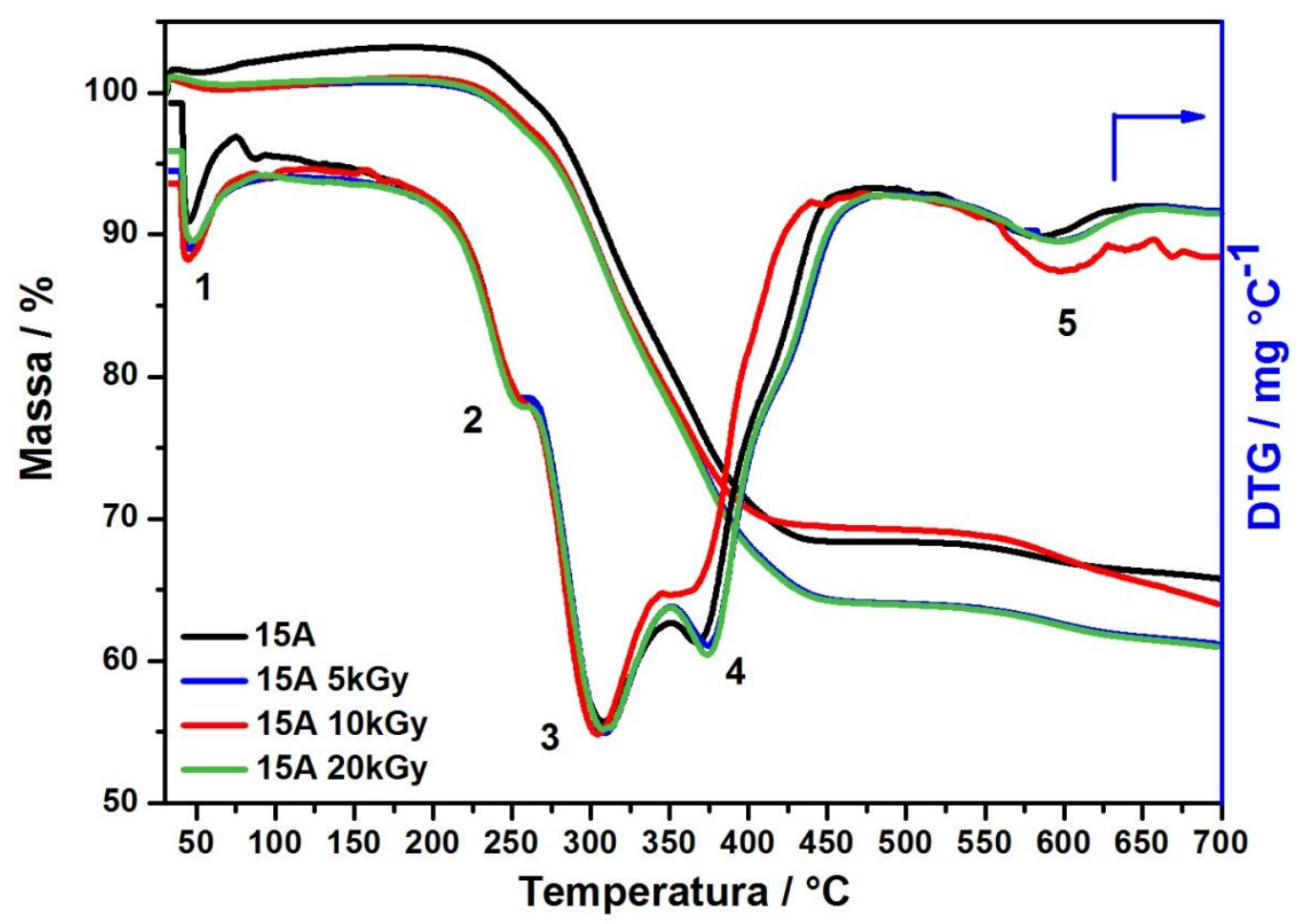

FIGURA 17 - Curvas TG e DTG obtidas em atmosfera de $\mathrm{N}_{2}$ para as amostras de argila Cloisite 15A antes e depois da irradiação.

A diferença verificada nas curvas termogravimétricas foi a quantidade de resíduo apresentada pelas amostras que diminuiu após o processamento por irradiação. As amostras não irradiada e irradiada a 5, 10 e 20kGy apresentaram a seguinte quantidade de resíduo: $66 \%, 61 \%, 61 \%$ e $64 \%$, respectivamente. Essa diferença pode estar relacionada com a degradação oxidativa das amostras como efeito direto da radiação que foi realizada em atmosfera de ar.

Os valores da temperatura inicial de decomposição, sua respectiva perda de massa e sua correlação com a estrutura do material estão descritos na TAB. 2. 
TABELA 2 - Resultados da análise térmica sob atmosfera da argila Cloisite 15A irradiada e não irradiada.

\begin{tabular}{c|c|c|c}
\hline Etapa & $\mathbf{T}_{\text {onset }} /{ }^{\circ} \mathbf{C}$ & $\begin{array}{c}\text { Perda de massa } / \\
\%\end{array}$ & Referências \\
\hline $\mathbf{1}$ & 35 & 0,8 & Perda de água \\
\hline $\mathbf{2}$ & 190 & 0,8 & $\begin{array}{c}\text { Perda de água de } \\
\text { cristalização }\end{array}$ \\
\hline $\mathbf{3}$ & 260 & 3,4 & $\begin{array}{c}\text { Decomposição de sais } \\
\text { orgânicos }\end{array}$ \\
\hline $\mathbf{4}$ & 345 & 18 & Perda de água estrutural \\
\hline $\mathbf{5}$ & 487 & 13 & \\
\hline
\end{tabular}

Os resultados da análise de difração de raios $X$ referentes às amostras de argila não irradiada e irradiadas estão representado na FIG. 18. Nesta mesma figura estão representados em forma de barra os valores correspondentes ao padrão da montmorilonita (ICCD número: 00-029-1498).

A estrutura cristalográfica da argila foi mantida mesmo após a radiação os espaçamentos basais característicos $[109,110]$ da argila foram mantidos em: $2 \theta \sim 7^{\circ}, d_{001}: 12,6-13,3 \AA \hat{A}$ e $2 \theta \sim 20^{\circ}, d_{020}: 4,5 \AA \hat{~}$. 


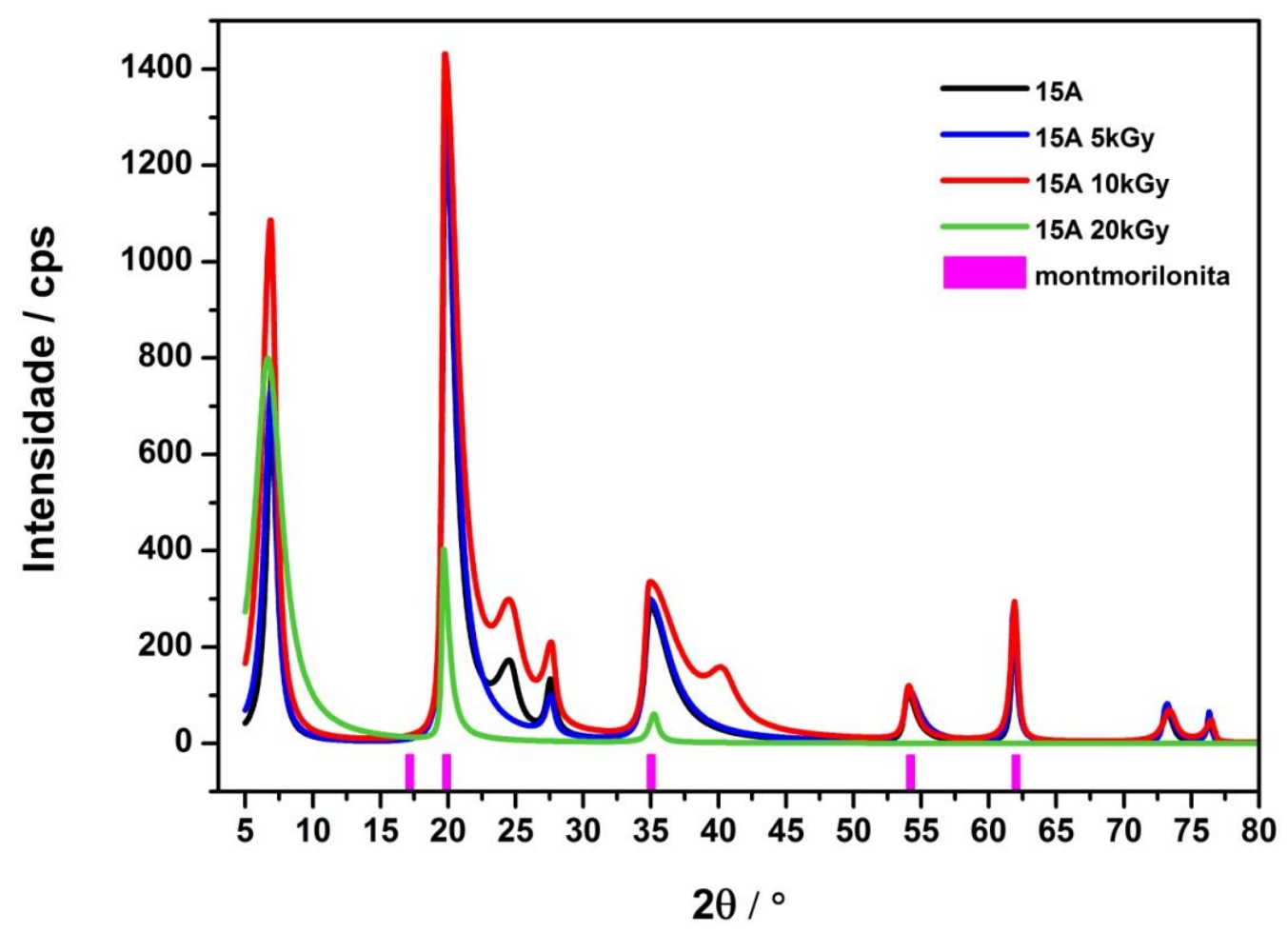

FIGURA 18 - Difratogramas de raios X das amostras de argila Cloisite 15A antes e depois da irradiação e em barras da montmorilonita.

As imagens obtidas pela técnica de microscopia eletrônica de varredura estão demonstradas na FIG. 19 e foram ampliadas em 1000x. Verificouse que as diferentes doses de irradiação não influenciaram no tamanho de partícula e também a tendência da argila de formar aglomerados foi observada em todas as amostras. A argila organofílica apresentou aparência desfolhada de formato irregular conforme reportado na literatura $[46,110]$. 

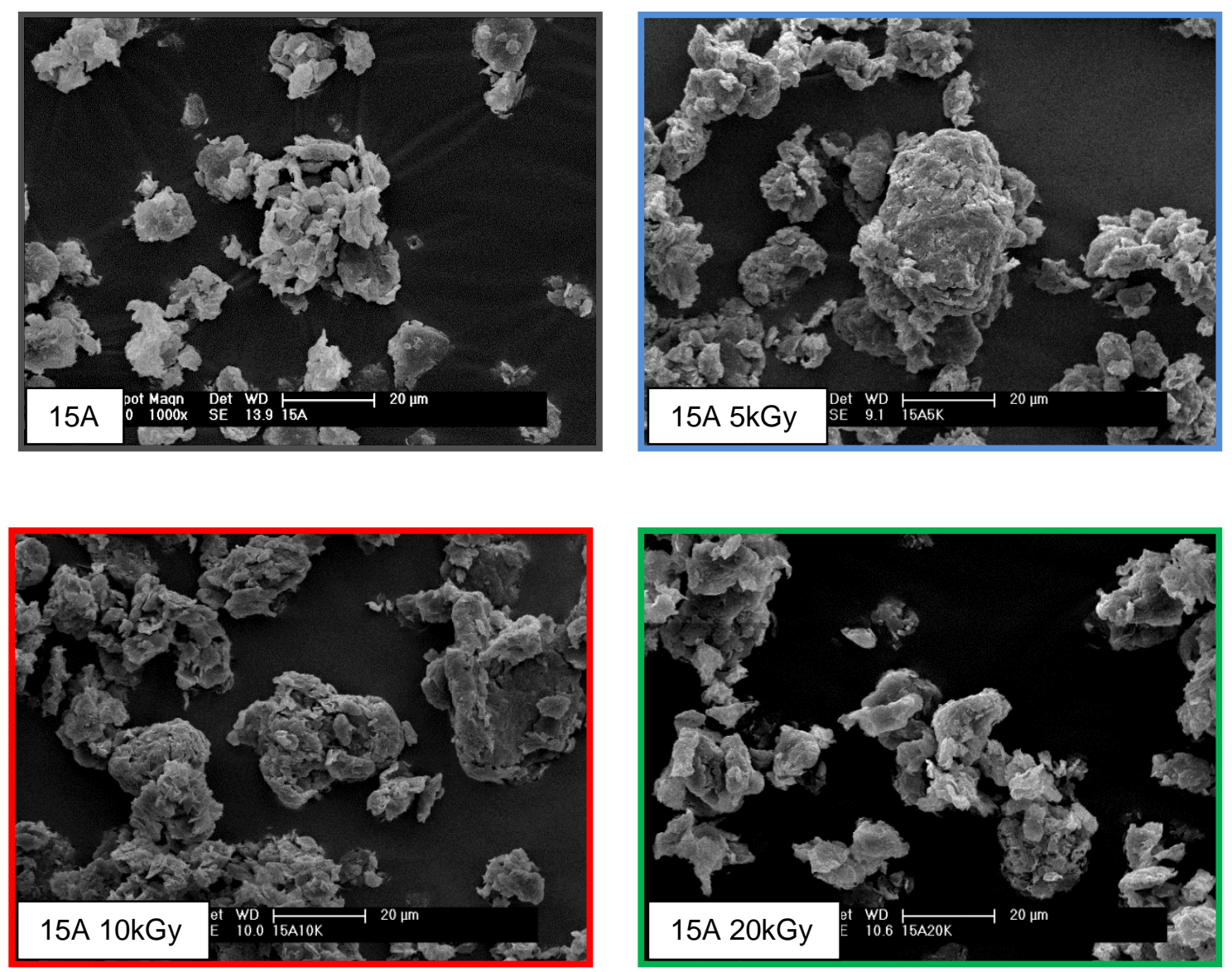

FIGURA 19 - Imagens de microscopia eletrônica de varredura das amostras de argila Cloisite 15A antes e depois da irradiação.

\subsubsection{Efeito da radiação ionizante em POSS 1163}

Os resultados das análises termogravimétricas estão descritos na TABELA 3 e as respectivas curvas estão representadas na FIG. 20. A diminuição de $T_{\text {onset }}$ das amostras irradiadas em relação à não irradiada está relacionada diretamente com a degradação da cadeia polimérica como efeito direto da irradiação em atmosfera de ar. 


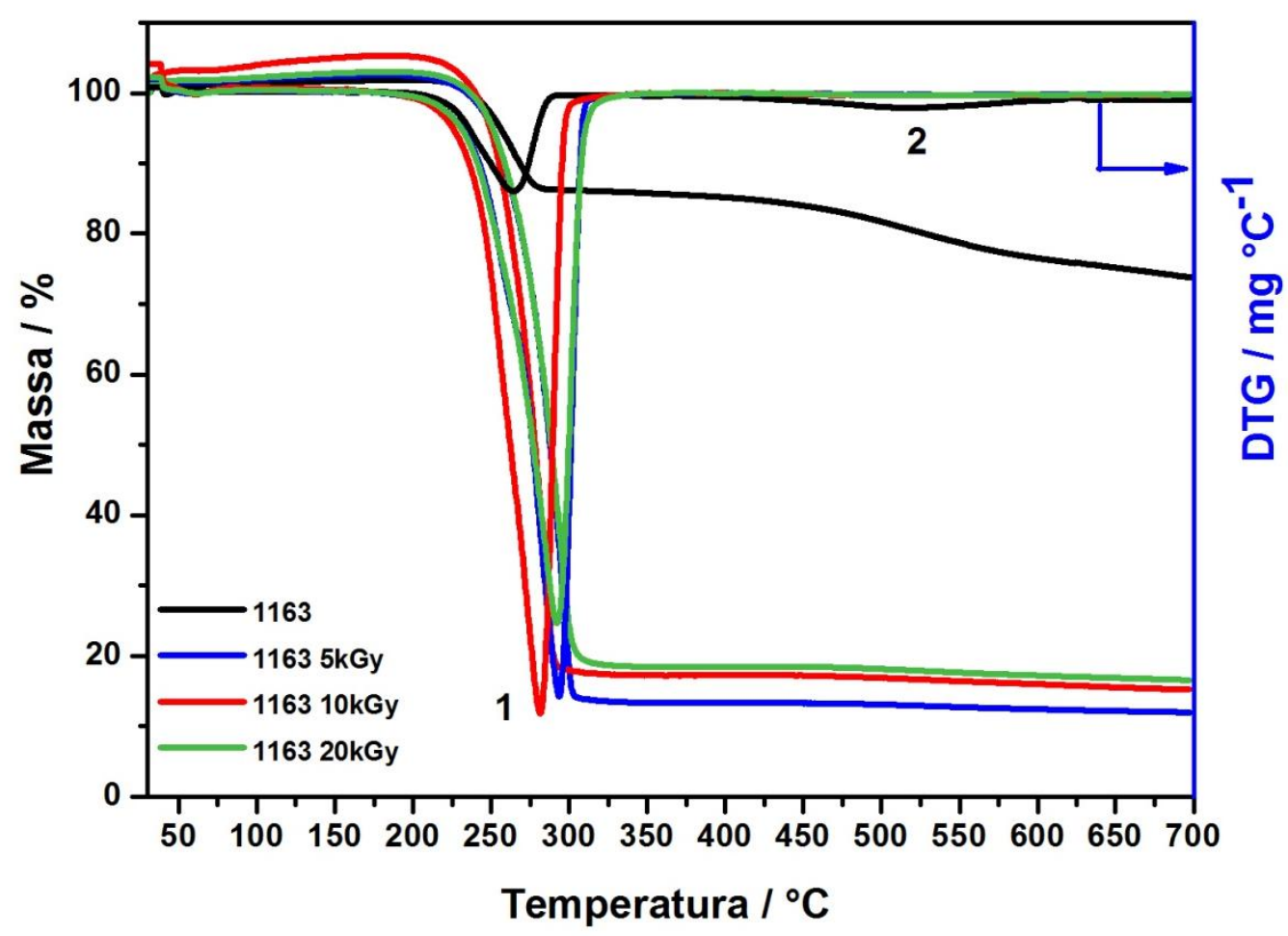

FIGURA 20 - Curvas TG e DTG obtidas para as amostras de POSS 1163 antes e depois do processo de irradiação

Para a amostra de POSS 1163 não irradiada verificou-se um valor residual muito alto, enquanto que após a irradiação as amostras apresentaram valores baixos de resíduos ao término da análise térmica. A diminuição da quantidade de resíduo (TAB. 3) da amostra não irradiada para as amostras irradiadas pode estar relacionada com as ligações $\mathrm{C}=\mathrm{C}$ da cadeia do POSS que foram oxidadas no processamento pela irradiação e durante a análise foi liberada devido ao aquecimento da amostra. O resíduo destas amostras indicou que provavelmente está ocorrendo a formação de óxido de silício. 
TABELA 3: Resultados da análise termogravimétrica em nitrogênio para o POSS 1163 antes e depois do processo de irradiação.

\begin{tabular}{c|c|c|c}
\hline Amostras & $\mathbf{T}_{\text {onset }} /{ }^{\circ} \mathbf{C}$ & $\begin{array}{c}\text { Perda de } \\
\text { massa / \% }\end{array}$ & Resíduo / \% \\
\hline $\mathbf{1 1 6 3}$ & 275 & 16 & $72 \%$ \\
\hline $\mathbf{1 1 6 3}$ 5kGy & 258 & 88 & $12 \%$ \\
\hline $\mathbf{1 1 6 3}$ 10kGy & 259 & 88 & $12 \%$ \\
\hline $\mathbf{1 1 6 3}$ 20kGy & 265 & 84 & $16 \%$ \\
\hline
\end{tabular}

Os resultados da análise de difração de raios $X$ referentes às amostras de POSS 1163 não irradiado e irradiados estão representados na FIG. 21 e após avaliação foi verificado que não apresentaram mudança significativa nos difratogramas [41]. Para este POSS as curvas mostraram o pico de maior intensidade em $2 \theta=6,5^{\circ} \mathrm{d}=13,5 \AA \hat{\text { e }}$ outros em: $2 \theta=6^{\circ}, \mathrm{d}_{110} \sim 14,5 \hat{\AA} ; 2 \theta=8^{\circ}$, $\mathrm{d}_{001} \sim 11 \AA \hat{\AA} ;$ e $2 \theta=24^{\circ}, \mathrm{d}_{511} \sim 3,7 \AA$ r referentes à ligação Si-O, de acordo com ICCD número 01-072-6106. 


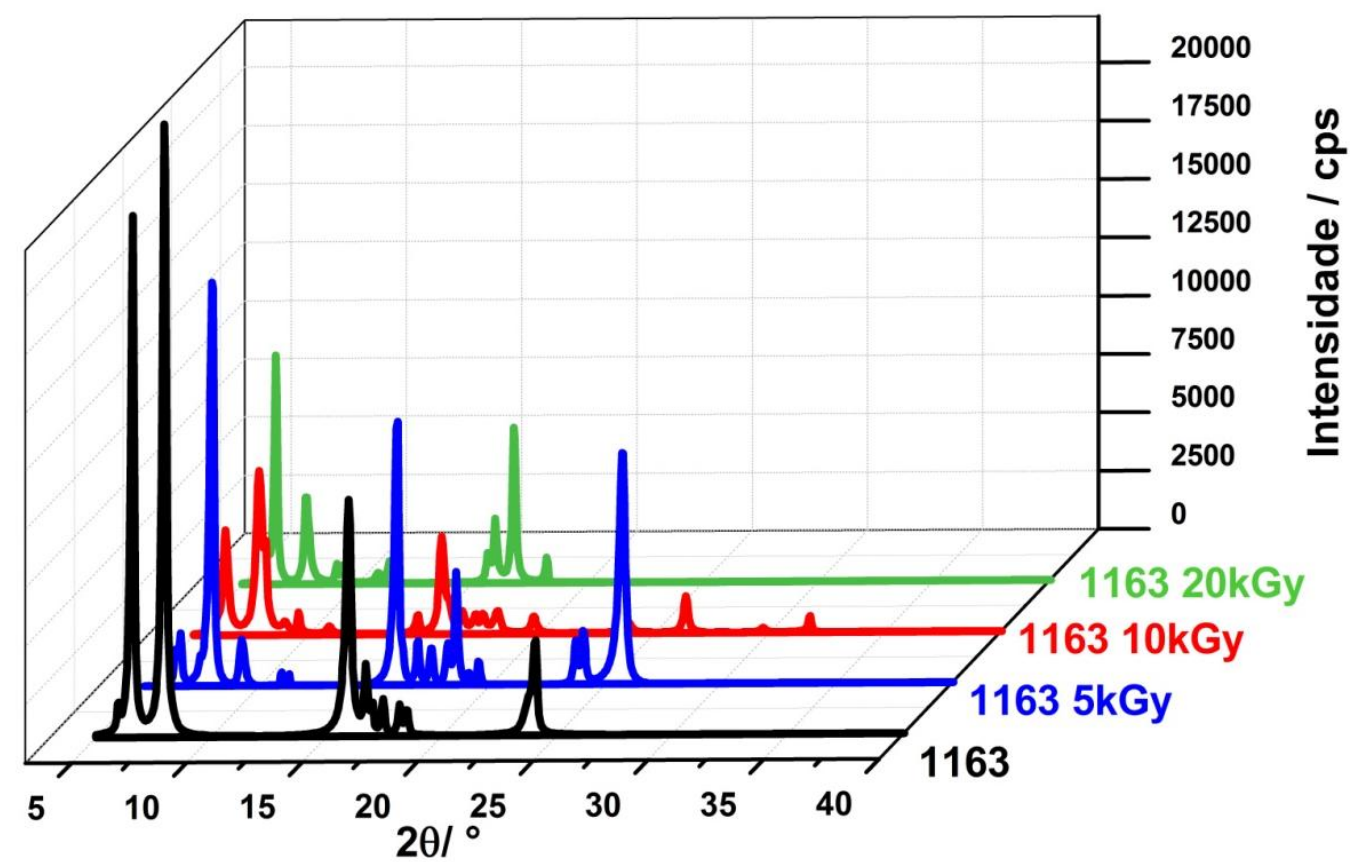

FIGURA 21 - Difratogramas de raios X para as amostras de POSS 1163 antes e depois do processo de irradiação.

As imagens de microscopia estão na FIG. 22 e foram ampliadas em 1000x. Verificou-se que a irradiação não influenciou no tamanho de partícula e que o formato de lâminas sobrepostas permaneceu após o processamento por irradiação. Porém, verificou-se uma tendência à destruição destes formatos pelo aparecimento de estruturas irregulares após a irradiação. Este efeito de degradação corroborou o que foi analisado pelas curvas termogravimétricas. 

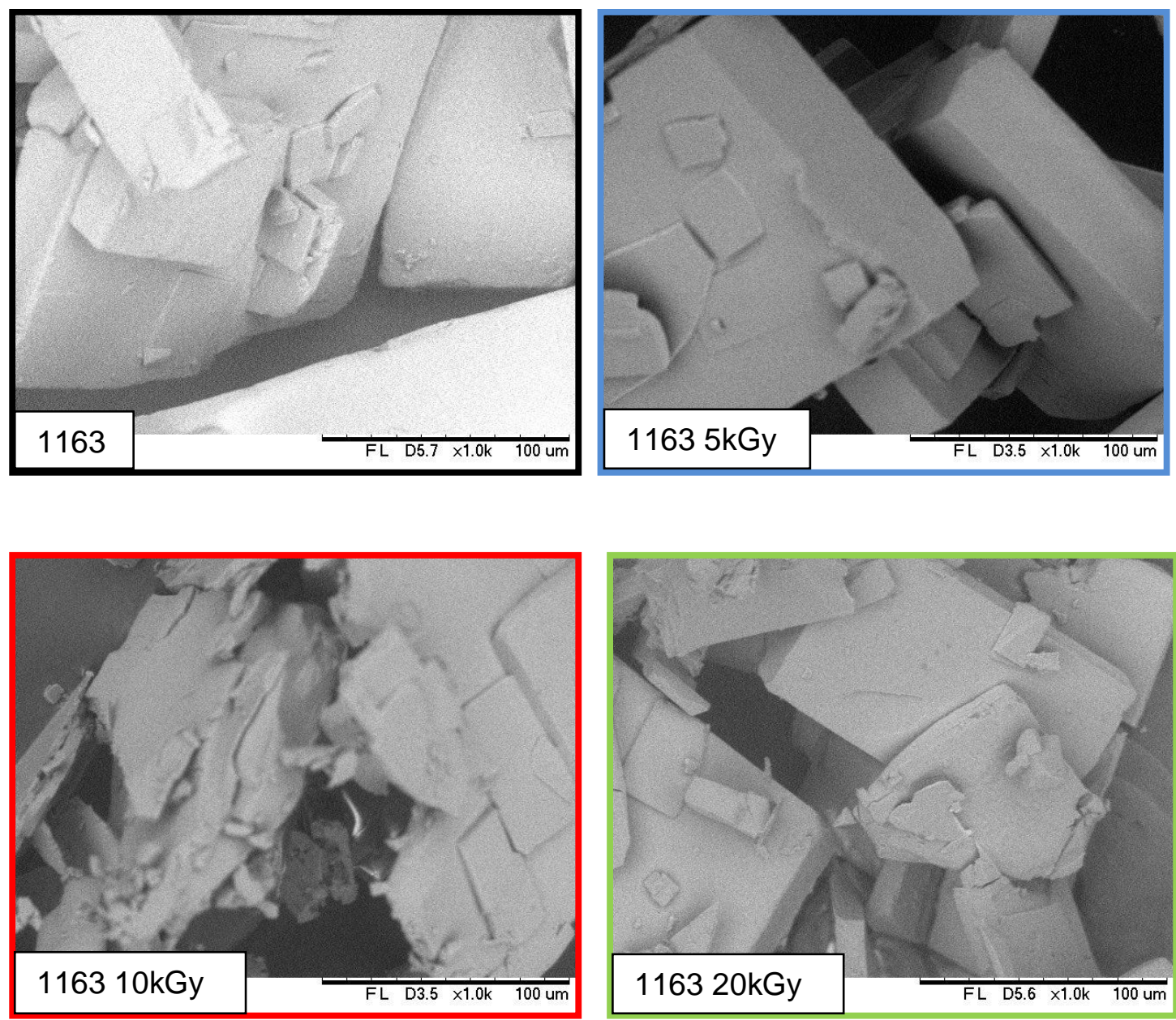

FIGURA 22 - Imagens de microscopia eletrônica de varredura das amostras de POSS 1163 antes e depois do processo de irradiação

\subsubsection{Efeito da radiação ionizante POSS 1160}

As curvas termogravimétricas referentes à decomposição do polímero POSS 1160 estão representadas na FIG. 23. Tanto o perfil das curvas como a temperatura inicial de decomposição $\left(272^{\circ} \mathrm{C}\right)$ não sofreram alteração significativa após o processamento por irradiação. A alteração mais significativa foi na quantidade do resíduo que aumentou com o aumento da dose irradiada, conforme descrito na TABELA 4. Este aumento de resíduo relaciona-se com a cisão de cadeia sofrida pela amostra durante a irradiação o que pode ter ocasionado um rearranjo da estrutura polimérica, resultando em mais ligações do tipo $\mathrm{Si}-\mathrm{O}$, mais estáveis. 


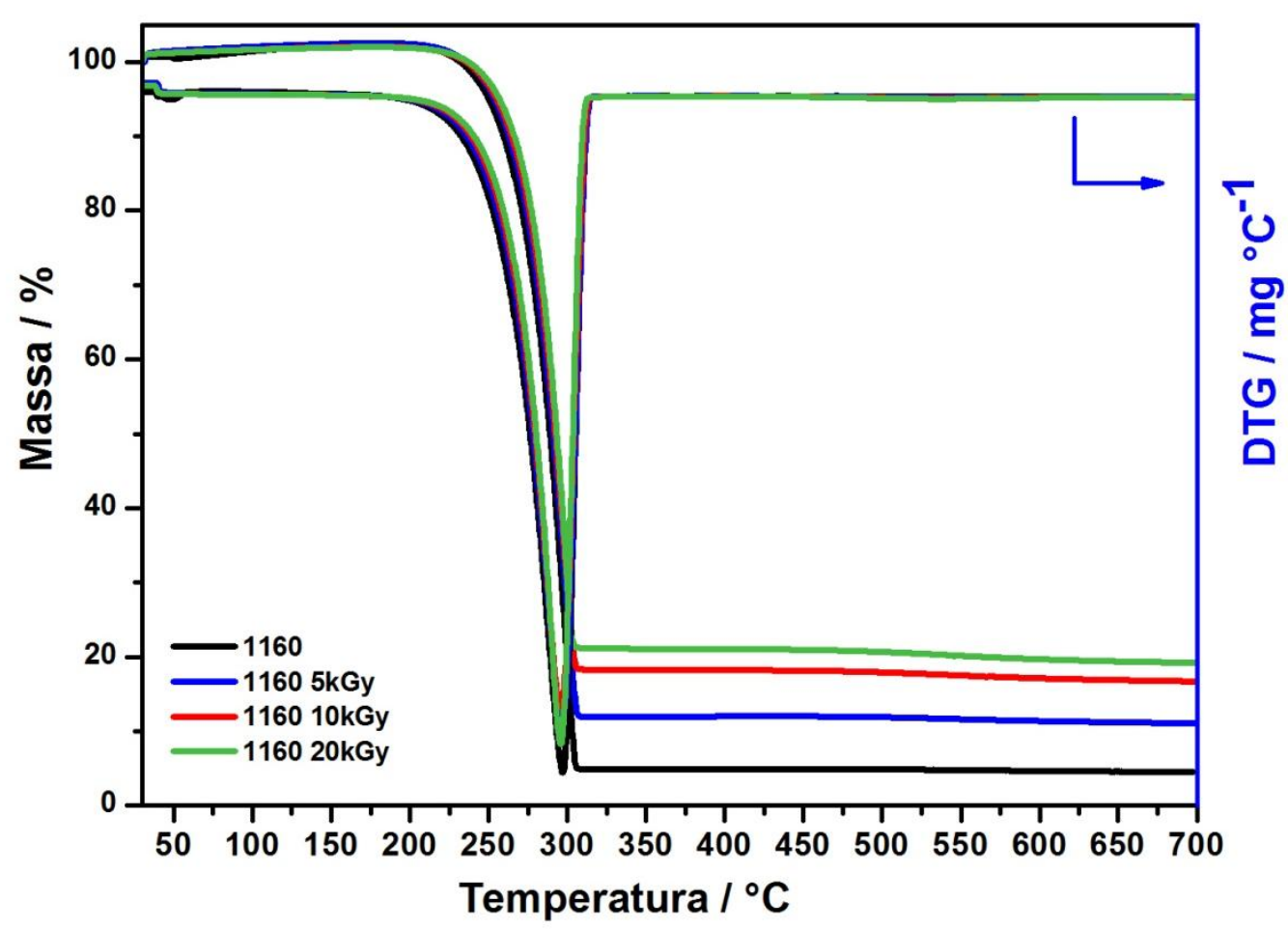

FIGURA 23 - Curvas TG e DTG obtidas para as amostras de POSS 1160 irradiada e não irradiada

TABELA 4 - Resultados da análise termogravimétrica em nitrogênio para o POSS 1160 antes e depois do processo de irradiação.

\begin{tabular}{c|c|c|c}
\hline Amostra & $\mathbf{T}_{\text {onset }} /{ }^{\circ} \mathbf{C}$ & $\begin{array}{r}\text { Perda de } \\
\text { massa / \% }\end{array}$ & Resíduo / \% \\
\hline $\mathbf{1 1 6 0}$ & 272 & 95 & 5 \\
\hline $\mathbf{1 1 6 0 ~ 5 ~ k G y ~}$ & 273 & 63 & 11 \\
\hline $\mathbf{1 1 6 0 ~ 1 0 ~ k G y}$ & 273 & 63 & 17 \\
\hline $\mathbf{1 1 6 0 ~ 2 0 ~ k G y}$ & 270 & 62 & 19 \\
\hline
\end{tabular}

Os resultados da análise de difração de raios $X$ referentes às amostras de POSS 1160 não modificado e modificados pela irradiação estão representados na FIG. 24 e de acordo com os resultados obtidos, verificou-se que a estrutura 
cristalográfica do polímero permaneceu inalterada. Para este polímero as curvas mostraram o pico de maior intensidade em $2 \theta=9,8^{\circ}$ com espaçamento basal $\left(\mathrm{d}_{120}\right)$ de $9 \AA$ [111], de acordo com ICCD número 01-072-6106.

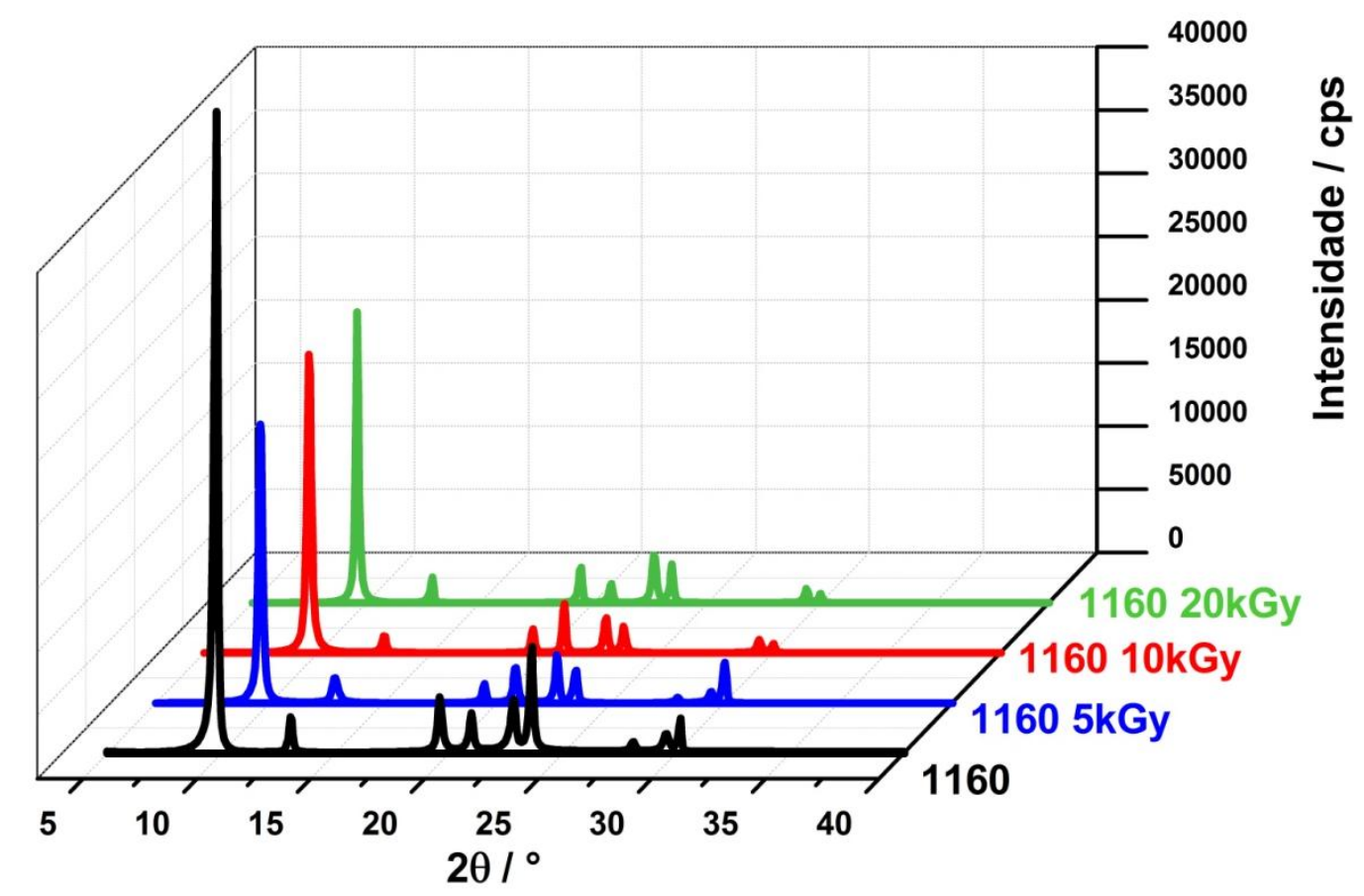

FIGURA 24 - Difratogramas de raios X para as amostras de POSS 1160 irradiada e não irradiada.

As imagens de microscopia representadas na FIG. 25 foram ampliadas em 1000x. Verificou-se que a irradiação não influenciou no tamanho de partícula e que houve a tendência da amostra de formar blocos sobrepostos. As partículas possuem formato de lâminas que foi observado em todas as amostras antes e depois da irradiação. 

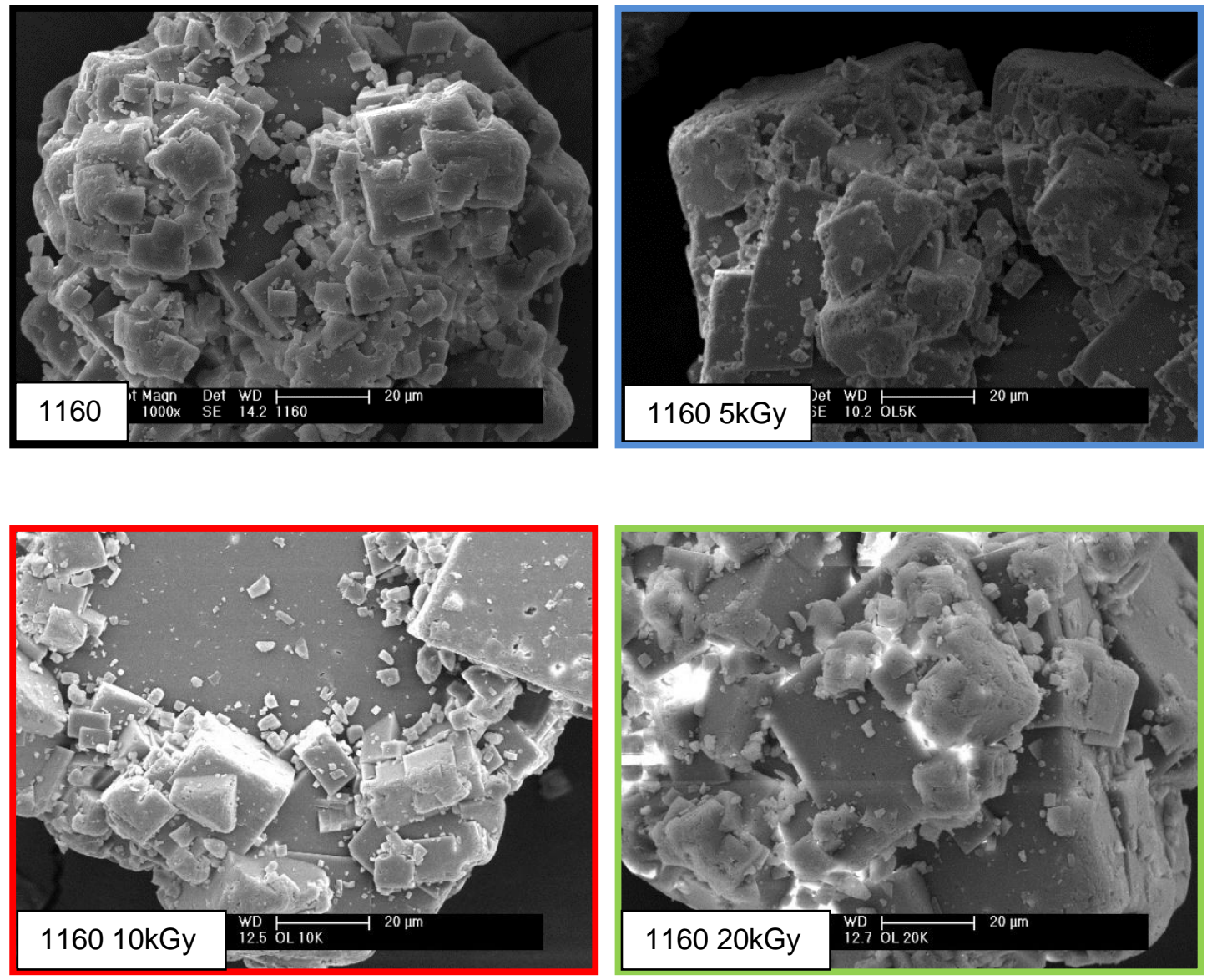

FIGURA 25 - Imagens de microscopia eletrônica de varredura de POSS 1160 antes e depois da irradiação

\subsubsection{Efeito da radiação ionizante em POSS 1159}

As curvas termogravimétricas da partícula POSS 1159 estão representadas na FIG. 26 e seus resultados na TAB. 5. As amostras apresentaram duas etapas de decomposição e resíduo em torno de $25 \%$, exceto a amostra irradiada a 5 kGy que apresentou resíduo de 35\%.

$>$ Etapa 1: de 50 a $80{ }^{\circ} \mathrm{C}$ refere-se à perda de água

$>$ Etapa 2: temperatura inicial decomposição referente à cadeia polimérica. 
Este polímero possui o grupo benzeno em sua terminação de cadeia, que pode ter causado um efeito de proteção na cadeia polimérica evitando assim, a cisão ou a oxidação que poderiam ser causadas pelo processamento de irradiação.

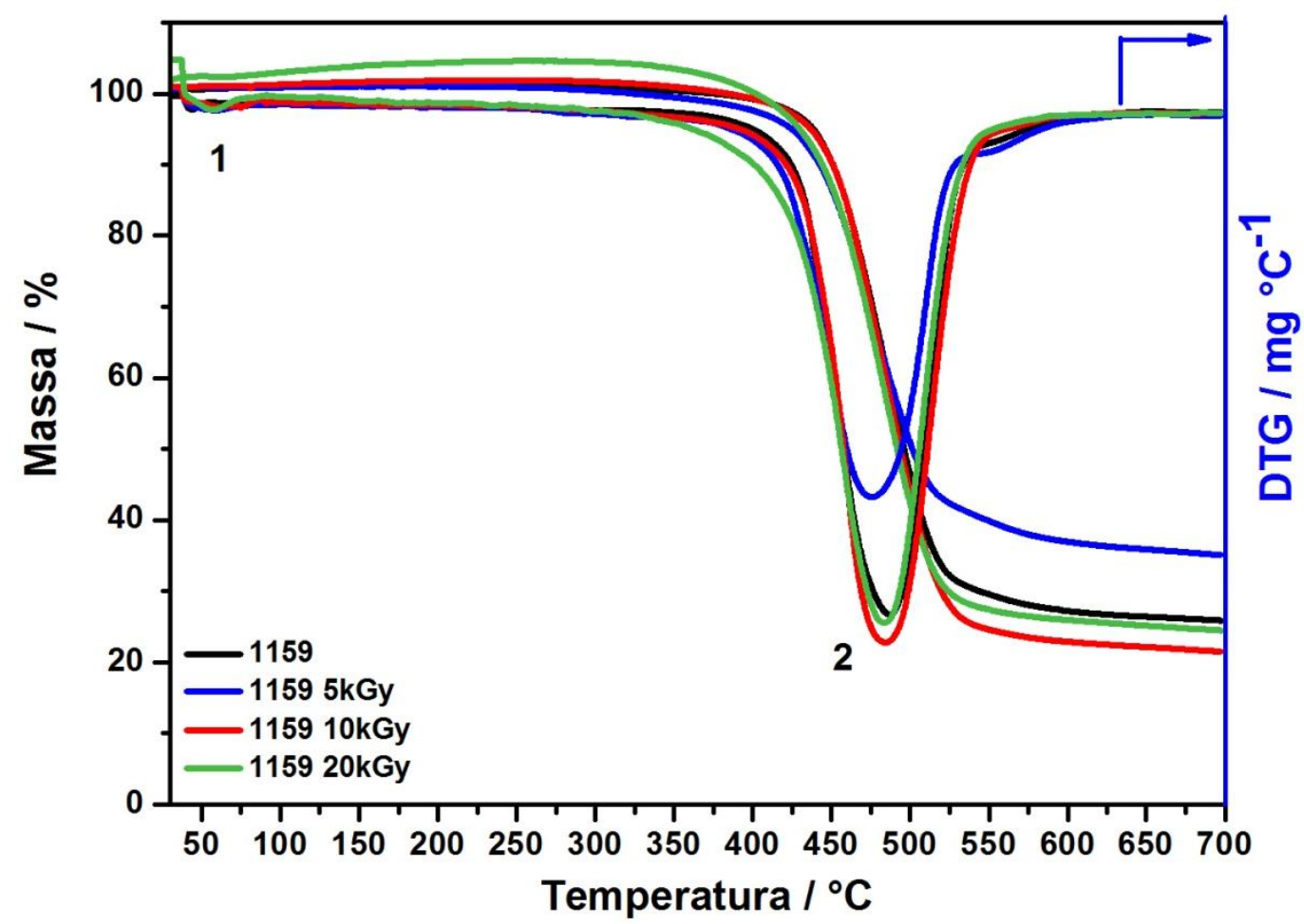

FIGURA 26 - Curvas TG e DTG obtidas para as amostras de POSS 1159 antes e depois da irradiação

TABELA 5 - Resultados da análise termogravimétrica em nitrogênio para o POSS 1159 antes e depois do processo de irradiação.

\begin{tabular}{c|c|c|c}
\hline Amostra & $\mathbf{T}_{\text {onset }} \mathbf{2} /{ }^{\circ} \mathbf{C}$ & $\begin{array}{c}\text { Perda de } \\
\text { massa / \% }\end{array}$ & Resíduo / \% \\
\hline $\mathbf{1 1 5 9}$ & 447 & 74 & 29 \\
\hline $\mathbf{1 1 5 9 5}$ kGy & 439 & 58 & 35 \\
\hline $\mathbf{1 1 5 9 1 0}$ kGy & 446 & 79 & 22 \\
\hline $\mathbf{1 1 5 9 ~ 2 0 ~ k G y}$ & 431 & 78 & 27 \\
\hline
\end{tabular}


Os resultados da análise de difração de raios $X$ referentes às amostras de POSS 1159 antes e depois do processo de irradiação estão representados na FIG. 27 e de acordo com os resultados obtidos, não apresentaram mudança significativa nos difratogramas. Para este polímero as curvas mostraram o pico de maior intensidade em $2 \theta=18^{\circ}, d_{040}=4,8 \AA \hat{~ e ~ o u t r o ~ e m: ~} 2 \theta=6,5^{\circ}, d_{110} \sim 13,5 \AA \hat{~ d e ~}$ acordo com ICCD número 01-072-6106.

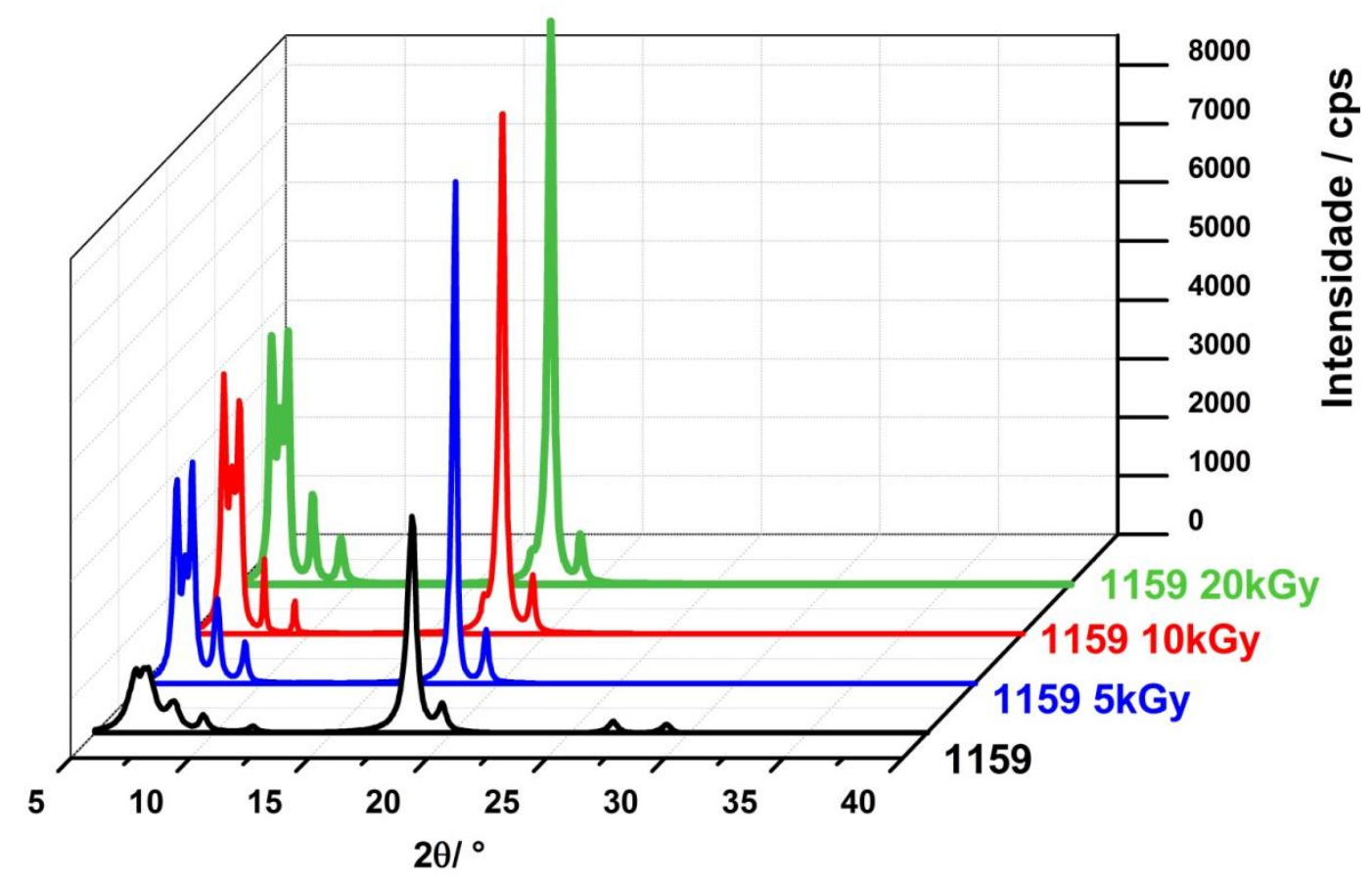

FIGURA 27 - Difratogramas de raios X para as nanopartículas 1159 antes e depois da irradiação

As imagens de microscopia estão representadas na FIG. 28 e foram ampliadas em 1000x. Verificou-se que a irradiação não influencia no tamanho de partícula e que a tendência deste POSS de formar aglomerados foi observada em todas as amostras. Nestas amostras as partículas não possuem formato bem definido. 

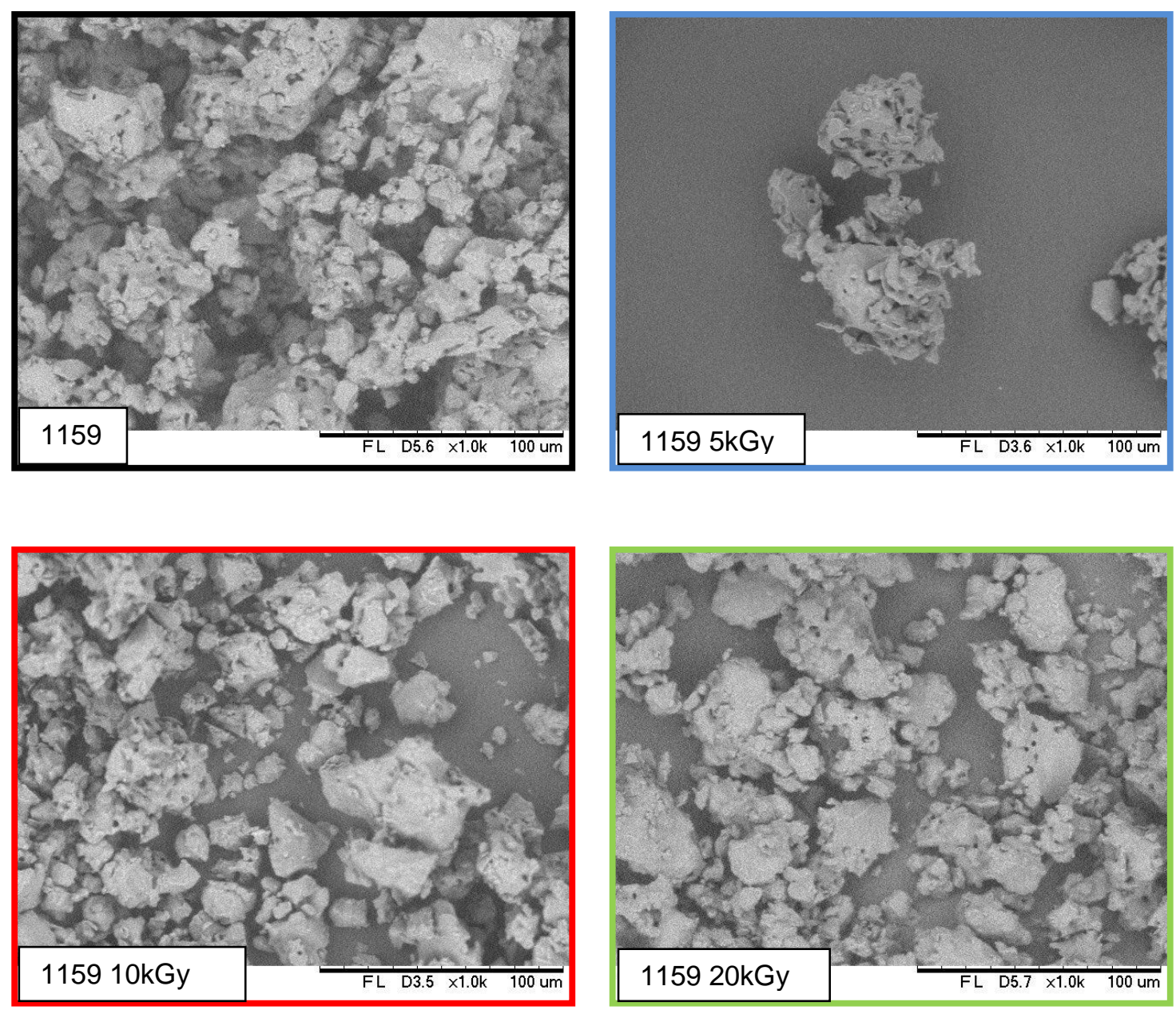

FIGURA 28 - Imagens de microscopia eletrônica de varredura das amostras de POSS 1159 antes e depois da irradiação.

\subsubsection{Efeito da radiação ionizante em elastômero não vulcanizado}

As curvas termogravimétricas referentes à decomposição do composto elastomérico não vulcanizado de fluoroelastômero estão representadas na FIG. 29. O perfil das curvas de decomposição não sofreu alteração significativa após o processamento por irradiação. O perfil de decomposição mostrou duas etapas: a primeira em torno de $190^{\circ} \mathrm{C}$ referente aos compostos voláteis presentes no material e a segunda etapa referente à decomposição da cadeia polimérica. $\mathrm{A}$ alteração mais significativa foi o decréscimo de $10^{\circ} \mathrm{C}$ da temperatura inicial de decomposição ( $T_{\text {onset}}$ ) das amostras irradiadas em relação à não irradiada. Os valores de $T_{\text {onset }}$ e de resíduo estão identificados na TABELA 66 . 


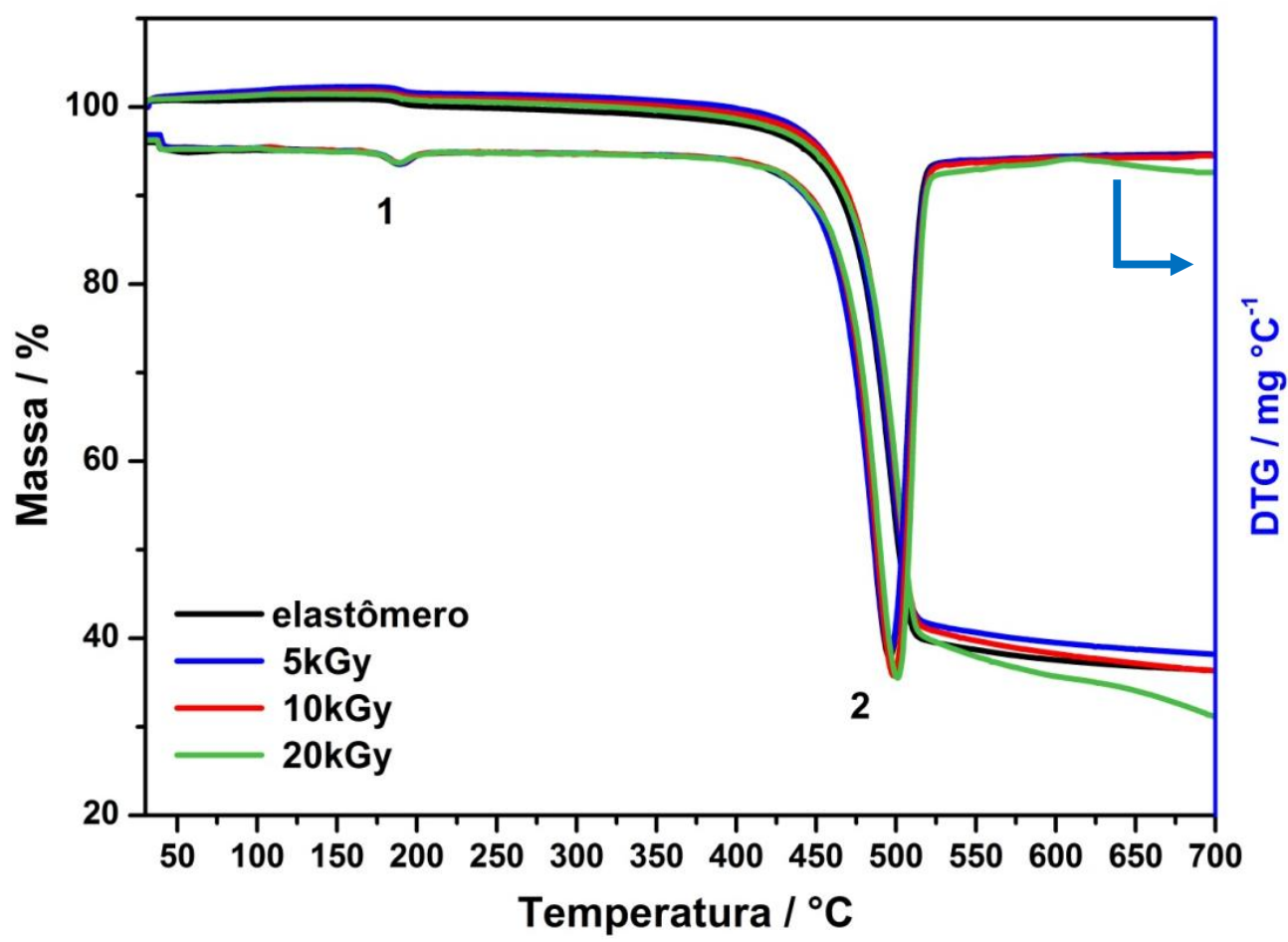

FIGURA 29 - Curvas TG e DTG obtidas para o elastômero não vulcanizado antes e depois do processo de radiação

TABELA 6 - Resultados da análise termogravimétrica em nitrogênio para o elastômero não vulcanizado antes e depois do processo de irradiação.

\begin{tabular}{c|c|c|c}
\hline Amostra & $\mathbf{T}_{\text {onset 2 }} /{ }^{\circ} \mathbf{C}$ & $\begin{array}{c}\text { Perda de } \\
\text { massa / \% }\end{array}$ & Resíduo / \% \\
\hline Elastômero & 473 & 63 & 36 \\
\hline 5kGy & 463 & 62 & 34 \\
\hline 10 kGy & 465 & 65 & 27 \\
\hline 20kGy & 467 & 62 & 34
\end{tabular}

Os resultados da análise de difração de raios $X$ de elastômero não irradiado e irradiado revelaram que os picos de maior intensidade sofreram um deslocamento para esquerda de acordo com o aumento da dose, e também os 
valores do espaçamento basal (d) aumentaram com o aumento da dose, conforme descrito na TABELA 7.

TABELA 7 - Resultados da difração de raios X para o fluoroelastômero não vulcanizado antes e depois irradiação.

\begin{tabular}{c|c|c}
\hline Amostras & $\mathbf{2 \theta}$ / $^{\circ}$ & $\mathbf{d} / \mathbf{A}$ \\
\hline Elastômero & 17,8 e 18,8 & 5 e 4,7 \\
\hline $\mathbf{5}$ kGy & 17,4 & 5,1 \\
\hline $\mathbf{1 0}$ kGy & 16,7 e 18 & 5,3 e 4,9 \\
\hline $\mathbf{2 0}$ kGy & 16,1 e 17,3 & 5,5 e 5,2 \\
\hline
\end{tabular}

As imagens de microscopia (FIG. 30) revelaram que não houve alteração superficial das amostras. As amostras irradiadas e não irradiadas apresentaram superfície irregular em decorrência do próprio processamento no cilindro para obtenção das mantas de elastômero. 

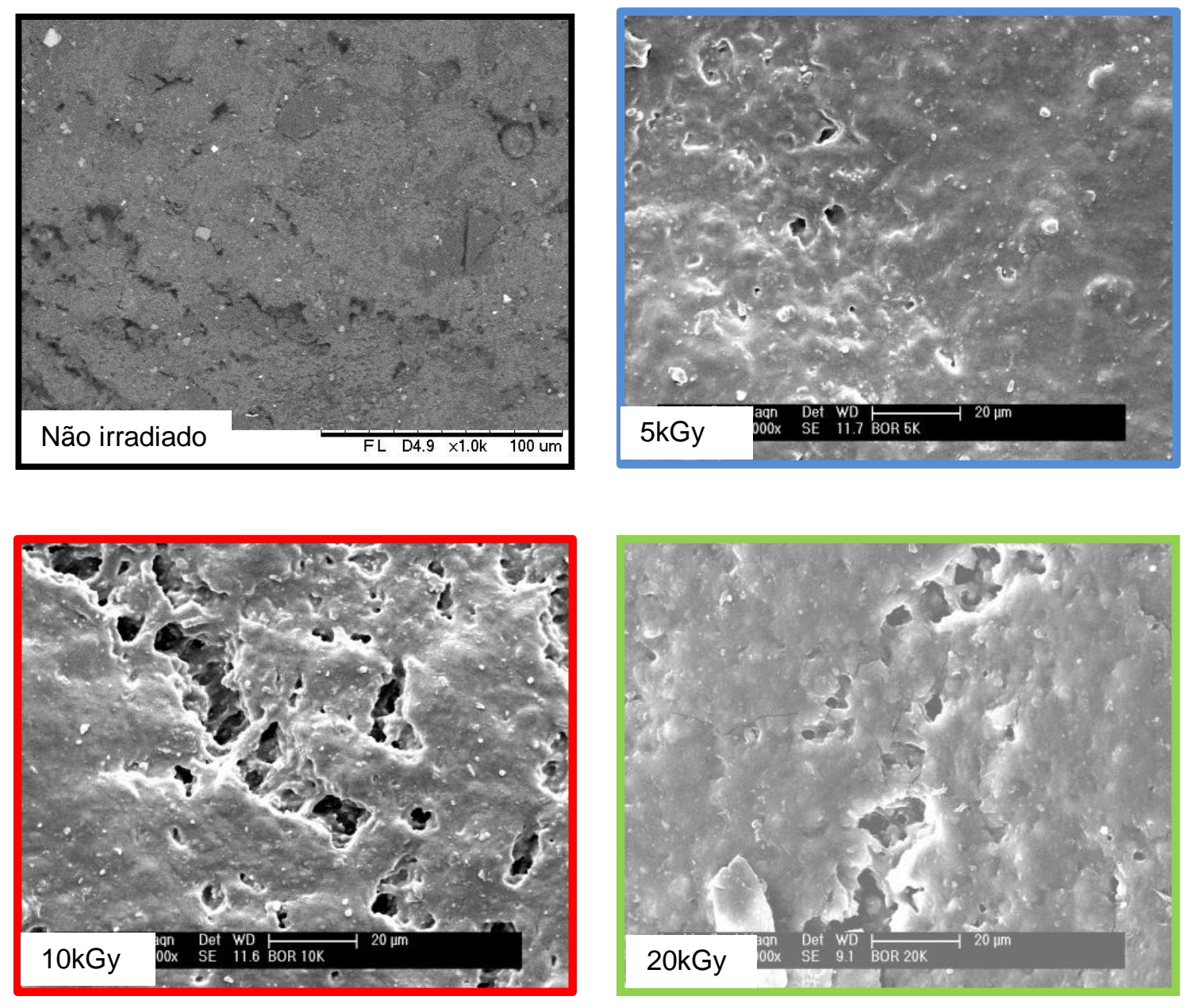

FIGURA 30 - Imagens de microscopia eletrônica de varredura das amostras de elastômero não vulcanizado antes e depois da irradiação

O cálculo para determinação do grau de intumescimento das amostras não vulcanizadas tanto antes quanto depois da irradiação não foi possível. Nas primeiras horas do teste as amostras intumesceram muito e começaram a apresentar resíduo depositado no fundo do béquer, indicando que pedaços da borracha se desprenderam e precipitaram, não sendo possível a pesagem do material.

A avaliação das propriedades mecânicas não foi possível nas amostras de borracha não vulcanizada, por isso foi realizada a vulcanização (processo de cura) destes elastômeros antes e depois da irradiação para avaliação destas propriedades. 


\subsubsection{Efeito da radiação ionizante em elastômero vulcanizado}

O processo de vulcanização consiste em unir quimicamente as cadeias poliméricas individuais, por meio das ligações cruzadas, visando à obtenção de uma rede tridimensional elástica que irá exibir as propriedades elastoméricas desejadas no produto final.

Para se determinar os parâmetros de vulcanização, foi realizada a análise reométrica em todas as amostras de elastômero: irradiado, não irradiado, incorporado e não incorporado com nanopartícula. Os resultados mostraram que as curvas de vulcanização não sofreram alterações significantes e que os valores tanto de torque quanto de tempo de vulcanização não foram afetados pelas modificações a que foi submetida a matriz polimérica. Para todas as amostras o tempo ótimo de vulcanização $\left(T_{90}\right)$ foi 1,5 minutos. Assim, os parâmetros de vulcanização foram fixados em 5 minutos a $195^{\circ} \mathrm{C}$ com pressão de 80 bar. Com os parâmetros definidos as borrachas foram vulcanizadas e foram obtidos filmes (FKM) com 0,2mm de espessura com superfície lisa, sem bolhas ou rugosidade.

De acordo com os resultados obtidos pela análise térmica (FIG. 31 e TAB. 8) verificou-se que não ocorreu a etapa de perda dos compostos voláteis. Este resultado era esperado, pois a liberação destes compostos ocorreu em torno de $190^{\circ} \mathrm{C}$ para o elastômero não vulcanizado e o processo de vulcanização foi realizado a $195^{\circ} \mathrm{C}$. Sendo assim, observou-se apenas a etapa de decomposição da cadeia polimérica, em torno de $470^{\circ} \mathrm{C}$. As temperaturas iniciais de decomposição das amostras vulcanizadas e a quantidade de resíduo do material vulcanizado variaram, respectivamente, em mais ou menos $1^{\circ} \mathrm{C}$ e $2 \%$ em relação ao elastômero não vulcanizado. 


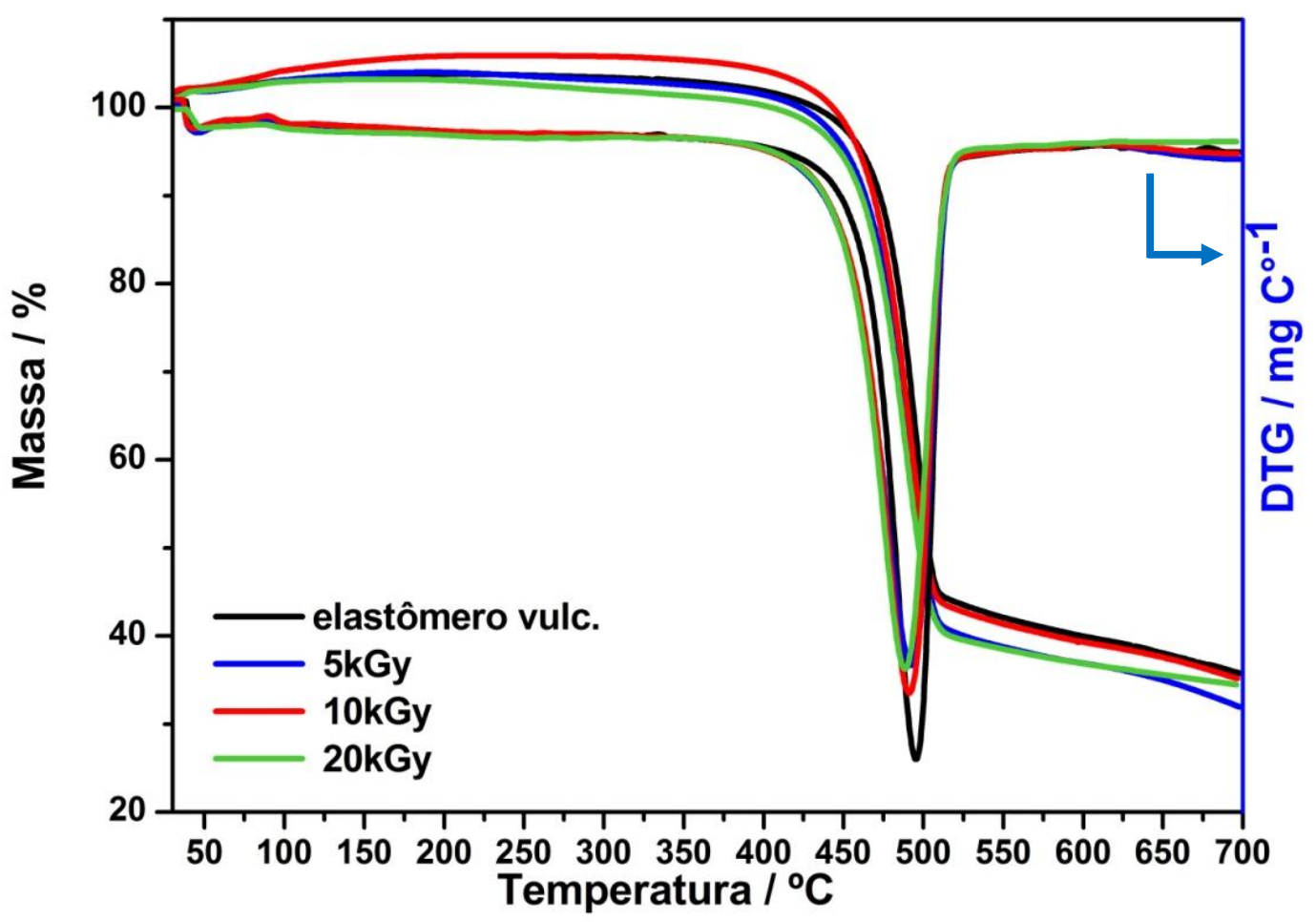

FIGURA 31 - TG e DTG do elastômero vulcanizado não irradiado e vulcanizado antes da irradiação

TABELA 8 - Resultados da análise termogravimétrica em nitrogênio para 0 elastômero vulcanizado (FKM) antes e depois do processo de irradiação.

\begin{tabular}{c|c|c|c}
\hline Amostra & $\mathbf{T}_{\text {onset }} \mathbf{2} /{ }^{\circ} \mathbf{C}$ & $\begin{array}{c}\text { Perda de } \\
\text { massa / \% }\end{array}$ & Resíduo / \% \\
\hline FKM & 473 & 61 & 36 \\
\hline FKM 5 kGy & 464 & 68 & 32 \\
\hline FKM 10 kGy & 465 & 63 & 35 \\
\hline FKM 20 kGy & 463 & 63 & 35
\end{tabular}


A irradiação pode causar três efeitos distintos, mas simultâneos no polímero: reticulação, cisão de cadeia e oxidação, a predominância de um desses efeitos está relacionada com os parâmetros de irradiação: dose irradiada, atmosfera durante a irradiação, temperatura; e também com os grupos funcionais presentes na cadeia polimérica. Um dos efeitos diretos da irradiação em presença de ar é a degradação da cadeia polimérica, tanto em decorrência de cisão como em decorrência da oxidação do filme. A degradação da cadeia polimérica resulta em diminuição do volume livre do elastômero e consequentemente na mobilidade da cadeia.

As propriedades mecânicas foram avaliadas quanto à tensão, deformação, alongamento e dureza. As curvas tensão x deformação do FKM antes e depois da irradiação estão representadas na FIG. 32. Analisando-se as curvas verificou-se o aumento do alongamento, o que indicou a tendência à degradação dos filmes como efeito direto da radiação ionizante.

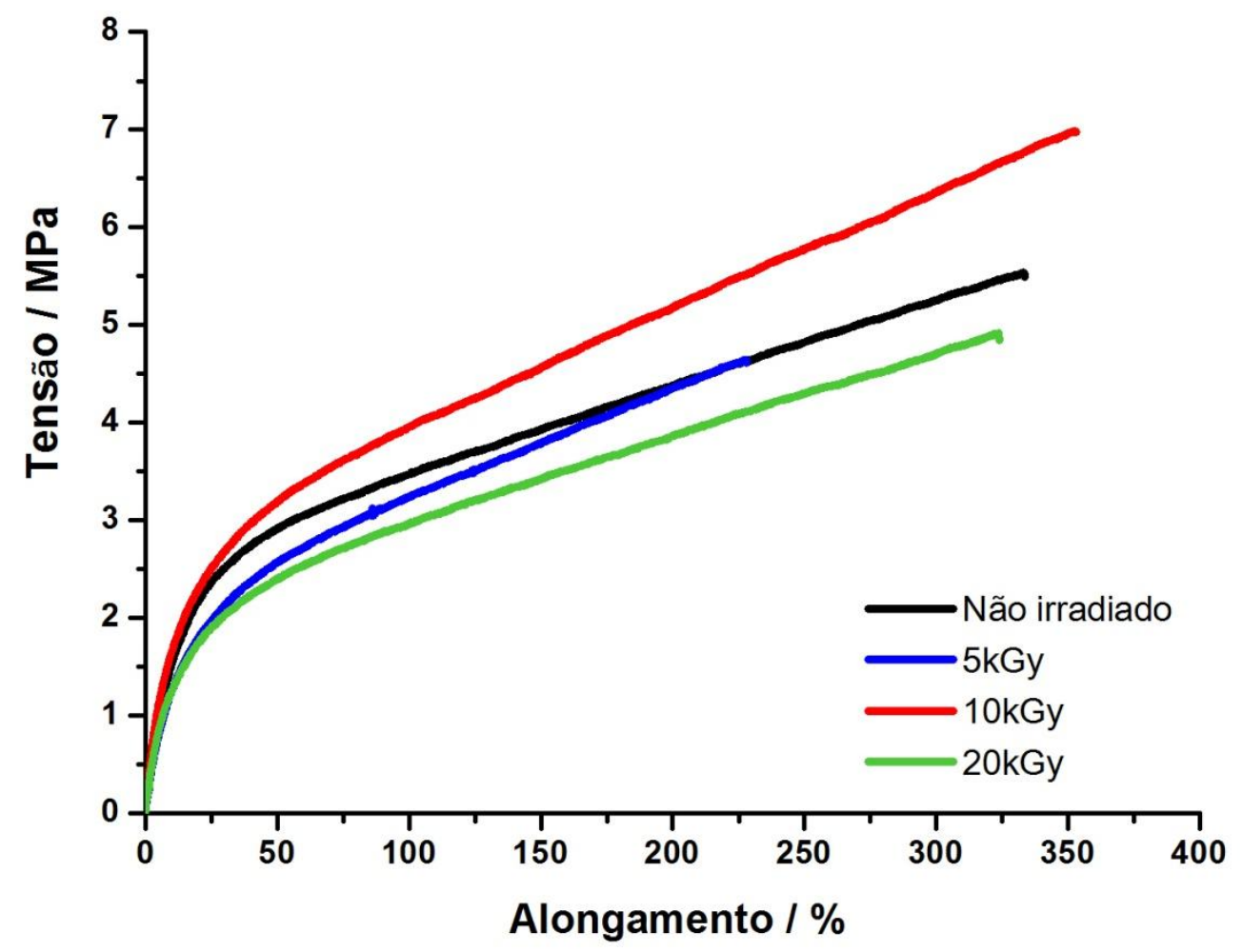

FIGURA 32 - Curvas tensão $x$ deformação dos filmes FKM não irradiado e vulcanizados antes da irradiação. 
A seguir estão demonstrados na

TABELA 99 os valores de tensão de ruptura, de alongamento na ruptura e módulo a 25\%. O filme irradiado a 10kGy apresentou aumento de alongamento em relação ao filme não irradiado. Este fato indicou o equilíbrio das reações de reticulação e de degradação ocorridas simultaneamente durante 0 processamento por irradiação.

TABELA 9: Valores de tensão e alongamento na ruptura e do módulo a 25\% para os filmes não irradiado e vulcanizados antes da irradiação

\begin{tabular}{c|c|c|c}
\hline Amostra & $\begin{array}{c}\text { Tensão de } \\
\text { ruptura / MPa }\end{array}$ & $\begin{array}{c}\text { Alongamento na } \\
\text { ruptura / MPa }\end{array}$ & $\begin{array}{c}\text { Módulo a } \\
\mathbf{2 5 \%} / \mathbf{~ M P a}\end{array}$ \\
\hline FKM & $5,5 \pm 0,7$ & $332 \pm 1,3$ & 2,35 \\
\hline FKM 5kGy & $4,7 \pm 1,0$ & $229 \pm 2,4$ & 1,99 \\
\hline FKM 10kGy & $7 \pm 1,6$ & $353 \pm 6,6$ & 1,91 \\
\hline FKM 20kGy & $5 \pm 0,32$ & $324 \pm 4,2$ & 2,51 \\
\hline
\end{tabular}

Para o ensaio de dureza Shore A, o elastômero foi vulcanizado em molde específico e posteriormente submetido à irradiação. Os valores determinados por este ensaio estão representados na FIG. 33. Observando-se os valores obtidos, verificou-se que os valores de dureza tendem a aumentar de acordo com a dose irradiada, indicando que o aumento da rigidez foi proporcional ao aumento da dose irradiada. Este aumento da rigidez está diretamente relacionado com a diminuição da mobilidade da cadeia confirmando o efeito de degradação na cadeia polimérica como consequência da radiação. 


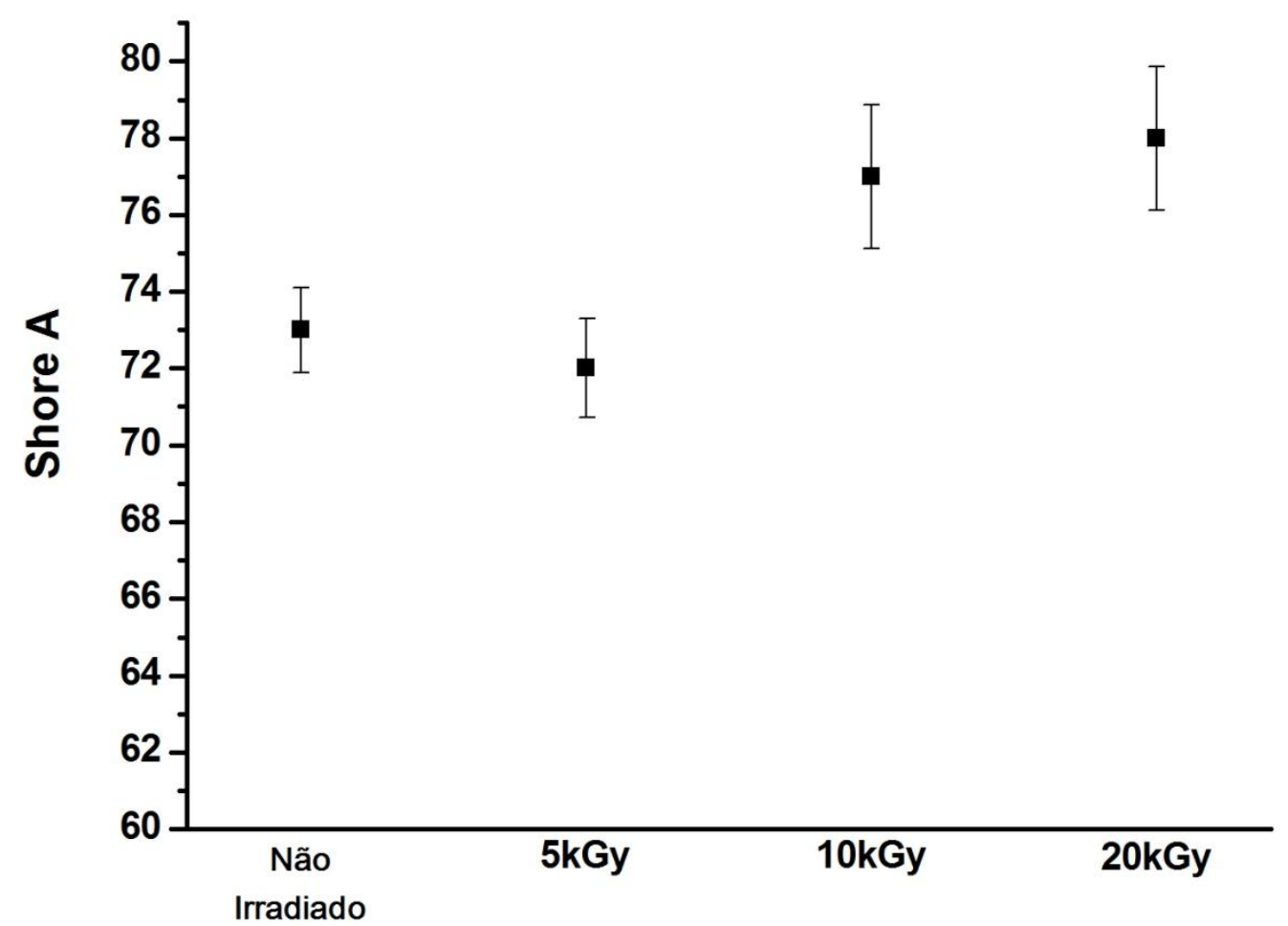

FIGURA 33 - Valores de dureza para o elastômero FKM não irradiado e vulcanizado antes da irradiação

Para se confirmar a predominância da degradação das amostras irradiadas foi realizado $o$ teste de intumescimento em solvente polar (metileilcetona - MEK) e solvente apolar (tolueno). Os resultados obtidos estão representados na FIG. 34FIGURA e a degradação dos filmes foi confirmada, como efeito direto da irradiação, pelo aumento do intumescimento das amostras. Por esta análise também foi possível determinar o perfil polar do material pela maior afinidade dos filmes FKM com o solvente MEK, visto que os filmes intumesceram acima de $60 \%$ enquanto que o intumescimento em tolueno foi menor de $10 \%$. 


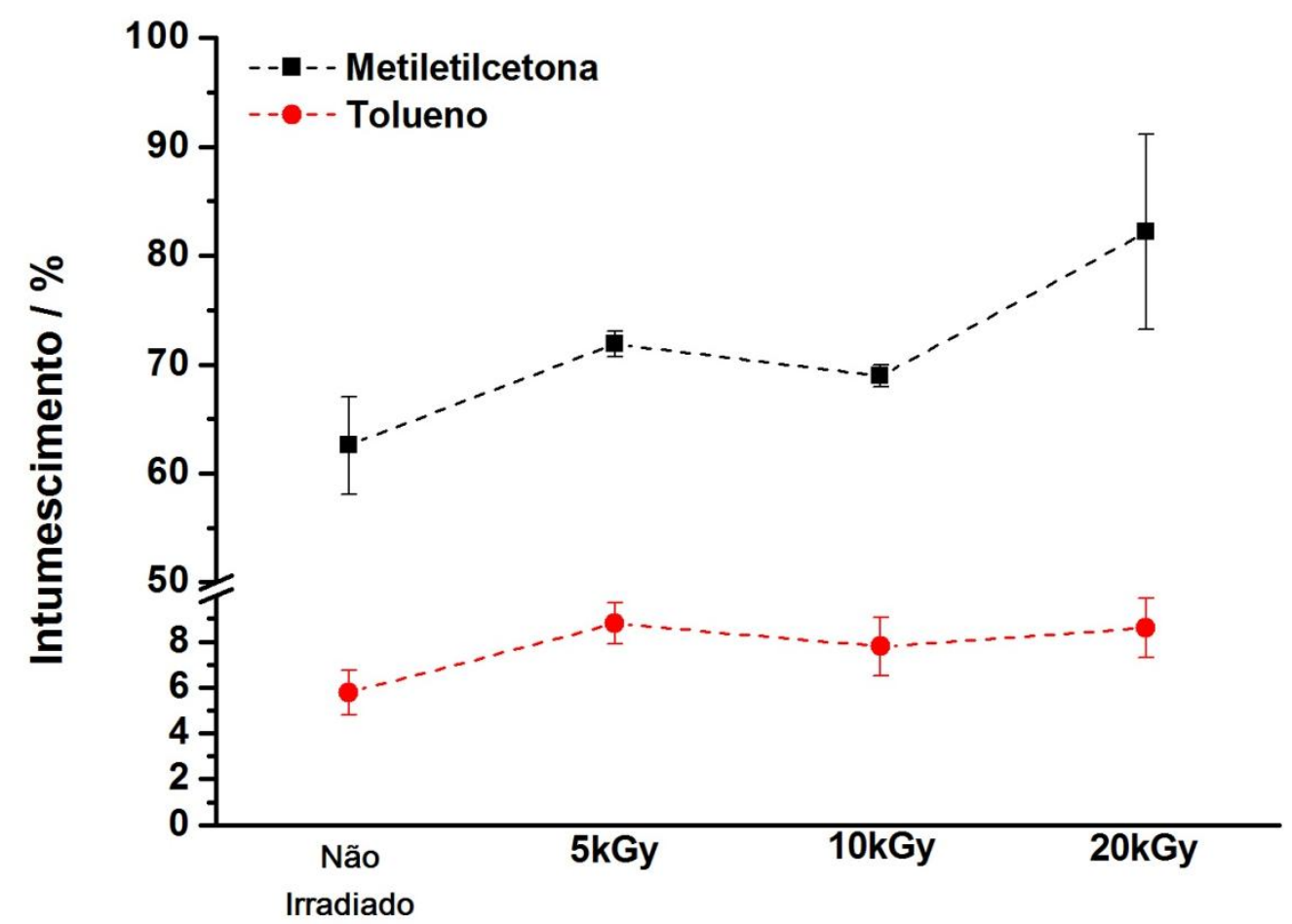

FIGURA 34 - Resultado de intumescimento do filme de elastômero FKM não irradiado e vulcanizado antes da irradiação, em diferentes solventes.

As imagens de microscopia (FIG. 35) revelaram que não houve alteração superficial das amostras. As amostras vulcanizadas antes da irradiação e a não irradiada apresentaram superfície menos irregular, mais homogênea (em relação ás amostras não vulcanizadas) em decorrência do processo de vulcanização para obtenção dos filmes elastoméricos. 

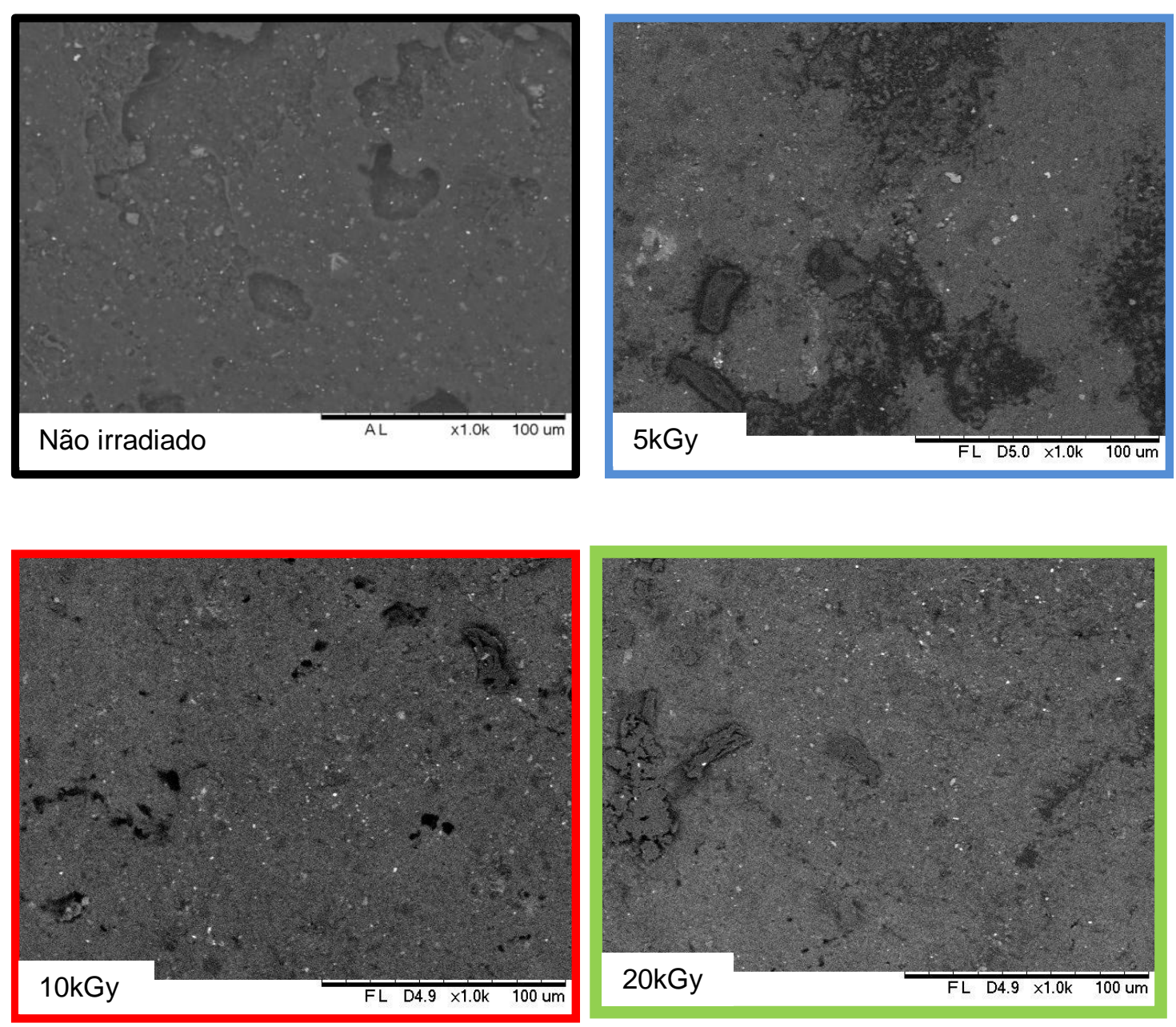

FIGURA 35 - Imagens de microscopia eletrônica de varredura das amostras de elastômero vulcanizado antes e depois da irradiação

\subsubsection{Efeito da radiação ionizante antes da vulcanização do elastômero}

Para se avaliar o efeito da irradiação nas amostras não vulcanizadas procedeu-se o processo de irradiação e posteriormente a vulcanização utilizandose os mesmos parâmetros mencionados anteriormente.

As curvas de tensão $x$ deformação para os filmes de elastômeros estão representadas na FIG. 36. A predominância do efeito de reticulação pelo processamento de irradiação em elastômero foi evidenciado pelo aumento do módulo e pela diminuição do alongamento. A amostra não vulcanizada possui maior mobilidade na cadeia polimérica e quando foi irradiada obteve uma maior concentração de radicais livres gerados na matriz polimérica, o que facilitou as 
reações de recombinação desses radicais, gerando ligações cruzadas e consequentemente a reticulação. Porém, os radicais que não se recombinaram continuaram disponíveis na cadeia até que durante o processo de vulcanização (pelo aquecimento) foi possível a recombinação destes radicais aumentando a densidade de reticulação da matriz polimérica e consequentemente a rigidez do FKM.

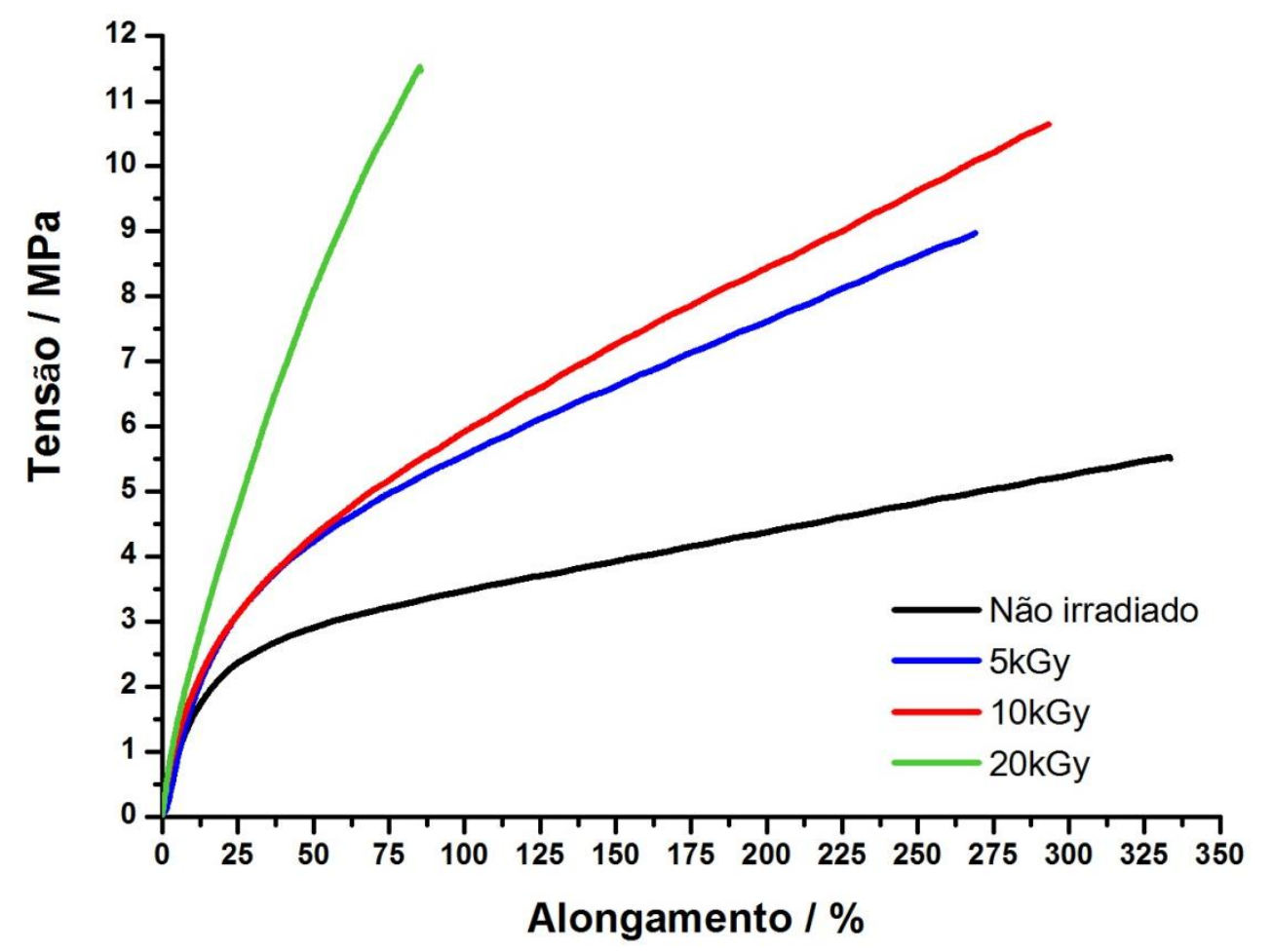

FIGURA 36 - Curvas de tensão x deformação dos filmes FKM não irradiado e vulcanizados após a irradiação

Os valores de tensão e alongamento na ruptura e também do módulo a $25 \%$ estão descritos na TAB. 10. 
TABELA 10: Valores de tensão e alongamento na ruptura e módulo a $25 \%$ dos filmes FKM não irradiado e vulcanizados após a irradiação

\begin{tabular}{c|c|c|c}
\hline Amostra & $\begin{array}{c}\text { Tensão na } \\
\text { ruptura / MPa }\end{array}$ & $\begin{array}{c}\text { Alongamento } \\
\text { na ruptura / \% }\end{array}$ & $\begin{array}{c}\text { Módulo a 25\% } \\
/ \mathbf{M P a}\end{array}$ \\
\hline FKM & $5,5 \pm 0,7$ & $332 \pm 1,3$ & 2,4 \\
\hline FKM 5kGy & $9 \pm 1,4$ & $269 \pm 1,9$ & 3,1 \\
\hline FKM 10kGy & $11 \pm 0,9$ & $293 \pm 3,2$ & 3,1 \\
\hline FKM 20kGy & $11,5 \pm 1,8$ & $86 \pm 3,5$ & 4,8 \\
\hline
\end{tabular}

Para determinação da dureza, o elastômero foi vulcanizado após a irradiação em molde específico, conforme citado na parte experimental. Os valores resultantes desta análise estão representados na FIG. 37. De acordo com os resultados obtidos foi verificado que as amostras irradiadas de 5 e 20 kGy apresentaram os maiores valores de dureza, corroborando o efeito da reticulação e o aumento da rigidez do FKM. 


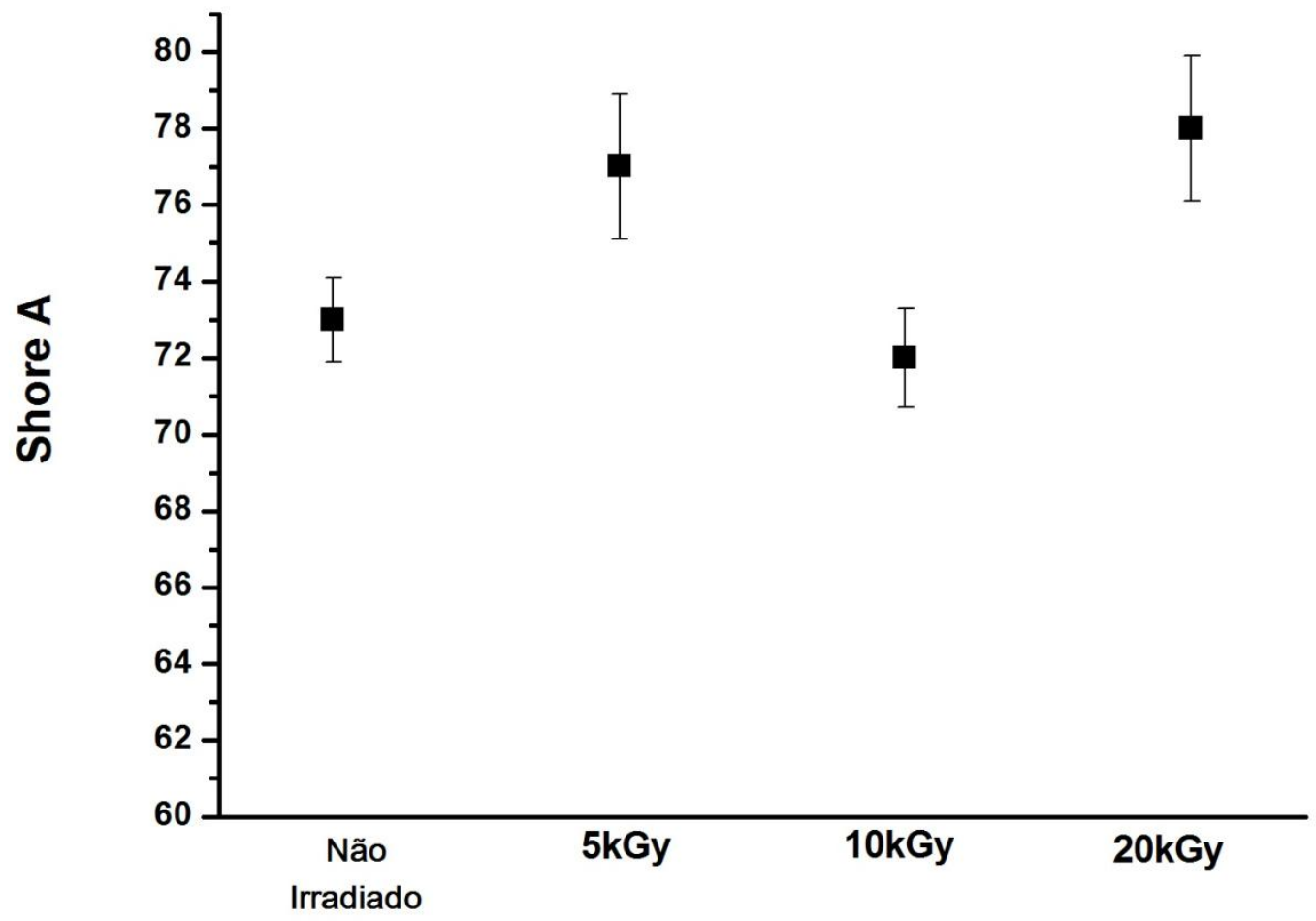

FIGURA 37 - Dureza do elastômero FKM não irradiado e vulcanizado após a irradiação.

Além do aumento no módulo o efeito da reticulação pode ser verificado também pelo teste de intumescimento, quanto menor o intumescimento maior a densidade de reticulação, o fenômeno de intumescimento é inversamente proporcional à densidade de ligações cruzadas [112]. Os filmes de FKM irradiados e vulcanizados foram imersos em metiletilcetona e tolueno (FIG. 38) e confirmaram o efeito da reticulação pela diminuição do intumescimento quando comparados com o filme apenas vulcanizado. 


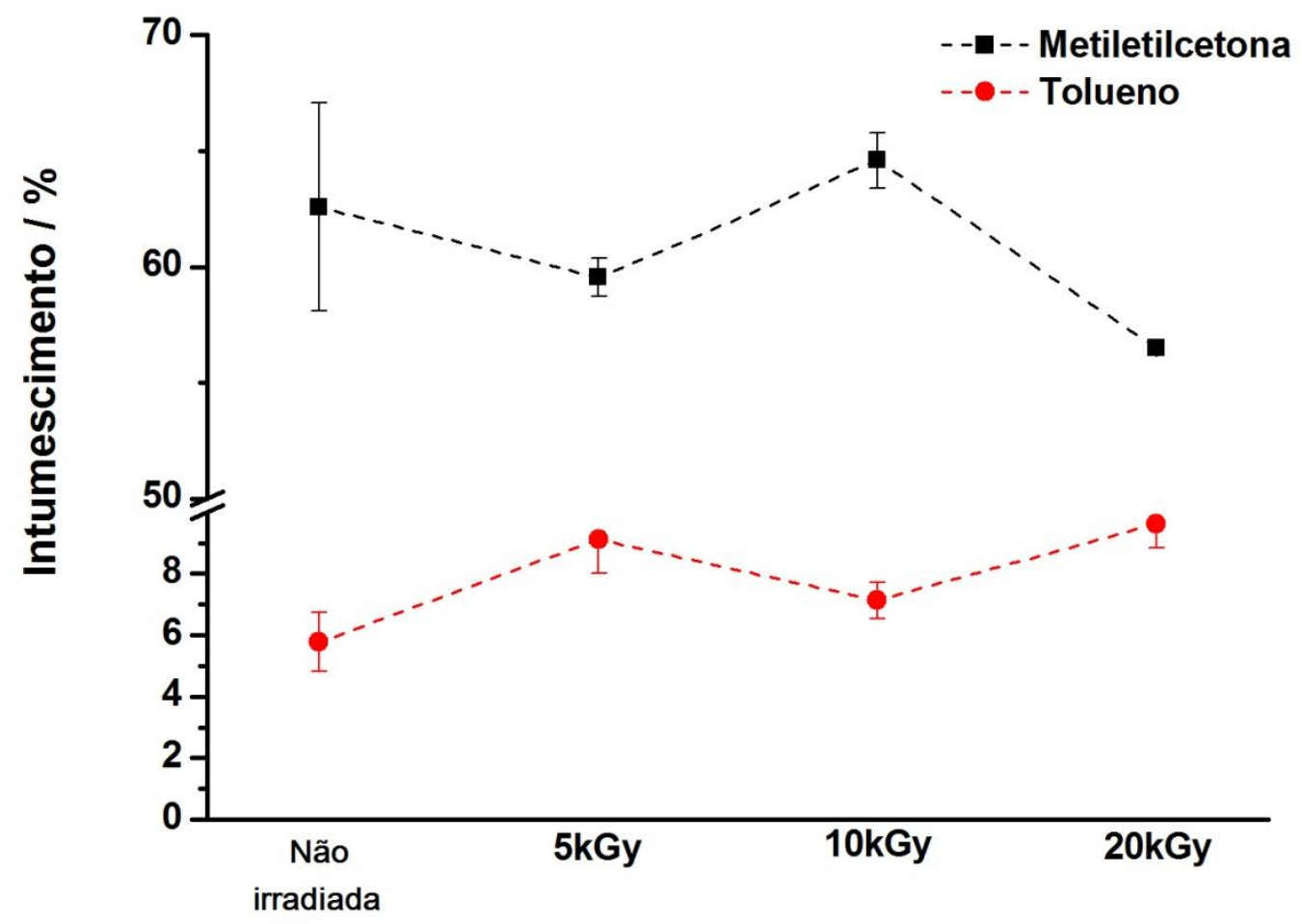

FIGURA 38 - Intumescimento dos filmes de FKM vulcanizados após a irradiação e do filme não irradiado em diferentes solventes

\subsection{Efeito da radiação ionizante nos filmes de nanocompósitos após o processo de vulcanização.}

Nesta etapa do trabalho os filmes de FKM incorporados com nanopartículas foram vulcanizados e em seguida submetidos ao processamento por irradiação. Durante a vulcanização do elastômero ocorreu a formação de uma rede tridimensional, a reticulação da cadeia polimérica que é a responsável pelas propriedades mecânicas do elastômero.

Para determinar o efeito da irradiação posterior à vulcanização, as amostras foram caracterizadas quanto às suas propriedades mecânicas de tensão, alongamento e dureza e também quanto ao intumescimento.

Como nesta etapa os filmes foram submetidos à irradiação já vulcanizados, a cadeia polimérica não possuía mobilidade suficiente para que os 
radicais se recombinassem entre si para formar as ligações cruzadas. Nesta etapa os radicais livres gerados na cadeia polimérica se recombinaram com os radicais livres presentes na atmosfera criando radicais peroxidícos e hidroxilas, causando a degradação por oxidação da cadeia polimérica. Além desse efeito também houve a cisão de cadeia que pode ter sido causada pela perda do flúor presente na cadeia polimérica que se recombinou formando outras pequenas cadeias poliméricas [113, 114]. As degradações por oxidação e por cisão de cadeia aumentam com a dose de irradiação devido ao aumento de radicais disponíveis.

De acordo com os valores apresentados na TAB. 11 de alongamento e de tensão verificou-se a predominância da degradação como efeito direto da irradiação nestes filmes. Os valores de alongamento para os filmes FKM incorporados e vulcanizados antes da irradiação, aumentaram com o aumento da dose irradiada, conforme descrito nas TAB 9 a 12, quando comparados aos filmes não irradiados. As curvas de tensão x deformação obtidas após a análise de ensaio mecânico estão apresentadas no apêndice C.

$\mathrm{Na}$ TAB. 11 estão descritos os valores de alongamento e de tensão na ruptura para os filmes incorporados com argila e vulcanizados antes da irradiação. As amostras incorporadas com 0,5\% e irradiadas a 10 e 20kGy apresentaram valores de alongamento inferiores ao filme não irradiado. Este comportamento pode estar relacionado com a boa dispersão de pequena quantidade de argila que contribuiu para o equilíbrio das reações de reticulação e de degradação durante o processamento por radiação. 
TABELA 11 - Valores de tensão e alongamento na ruptura para os filmes FKM incorporados com argila Cloisite 15A, vulcanizados antes da irradiação e não irradiado.

\begin{tabular}{c|c|c|c}
\hline Filme & $\begin{array}{c}\text { Tensão na } \\
\text { ruptura / MPa }\end{array}$ & $\begin{array}{c}\text { Alongamento } \\
\text { na ruptura / } \%\end{array}$ & $\begin{array}{c}\text { Módulo a } \\
\mathbf{2 5} \%\end{array}$ \\
\hline $\begin{array}{c}\text { 0,5 - 15A - Não } \\
\text { irradiado }\end{array}$ & $7,3 \pm 1,9$ & $335 \pm 1,23$ & 2,5 \\
\hline $\mathbf{0 , 5}$ - 15A - 5kGy & $6,4 \pm 0,8$ & $368 \pm 1,15$ & 2,0 \\
\hline $\mathbf{0 , 5}$ - 15A - 10kGy & $5,4 \pm 0,6$ & $236 \pm 1,14$ & 2,5 \\
\hline $\mathbf{0 , 5}$ - 15A - 20kGy & $4,3 \pm 0,48$ & $250 \pm 2,88$ & 1,9 \\
\hline $\begin{array}{c}\text { 1 - 15A - Não } \\
\text { irradiado }\end{array}$ & $3,5 \pm 0,9$ & $190 \pm 3,9$ & 1,6 \\
\hline $\mathbf{1}$ - 15A - 5kGy & $7 \pm 1,5$ & $295 \pm 4,5$ & 2,6 \\
\hline 1 - 15A - 10kGy & $4,9 \pm 0,5$ & $233 \pm 3,2$ & 2,1 \\
\hline 1 - 15A - 20kGy & $5,4 \pm 0,9$ & $290 \pm 2,8$ & 2,3 \\
\hline 2 - 15A - Não & $4,7 \pm 0,7$ & $83 \pm 1,1$ & 3,1 \\
\hline irradiado & & $205 \pm 2,1$ & 1,9 \\
\hline - 15A - 5kGy & $4,4 \pm 0,1$ & $196 \pm 3,2$ & 2,9 \\
\hline 2 - 15A - 10kGy & $6,4 \pm 0,4$ & $278 \pm 3,7$ & 2,2 \\
\hline 2 - 15A - 20kGy & $5 \pm 0,9$ & & \\
\hline
\end{tabular}

Na TAB. 12 estão descritos os resultados de propriedades mecânicas obtidas para o FKM incorporado com POSS 1159. De acordo com os resultados apresentados, confirmou-se o efeito da degradação devido a irradiação pelo aumento do alongamento dos filmes FKM irradiados em relação ao não irradiado. 
TABELA 12 - Valores de tensão e alongamento na ruptura para os filmes FKM incorporados com POSS 1159 vulcanizados antes da irradiação e não irradiado.

\begin{tabular}{c|c|c|c}
\hline Filme & $\begin{array}{c}\text { Tensão na } \\
\text { ruptura / MPa }\end{array}$ & $\begin{array}{c}\text { Alongamento } \\
\text { na ruptura / } \%\end{array}$ & $\begin{array}{c}\text { Módulo a } \\
\mathbf{2 5 \%}\end{array}$ \\
\hline $\begin{array}{c}\mathbf{0 , 5} \text { - 1159 - Não } \\
\text { irradiado }\end{array}$ & $8,3 \pm 2,1$ & $330 \pm 1,1$ & 3,0 \\
\hline $\mathbf{0 , 5}$ - 1159 - 5kGy & $6 \pm 2,2$ & $305 \pm 8,1$ & 2,3 \\
\hline $\mathbf{0 , 5}$ - 1159 - 10kGy & $5,4 \pm 0,7$ & $336 \pm 3,9$ & 1,7 \\
\hline $\mathbf{0 , 5}$ - 1159 - 20kGy & $5 \pm 0,4$ & $344 \pm 3,2$ & 2,1 \\
\hline $\begin{array}{c}\text { 1 - 1159 - Não } \\
\text { irradiado }\end{array}$ & $4,6 \pm 0,4$ & $316 \pm 4,3$ & 1,7 \\
\hline $\mathbf{1}$ - 1159 - 5kGy & $5,5 \pm 0,5$ & $322 \pm 4,4$ & 2,0 \\
\hline $\mathbf{1}$ - 1159 - 10kGy & $5,7 \pm 0,6$ & $359 \pm 2,8$ & 1,9 \\
\hline $\mathbf{1 ~ - ~ 1 1 5 9 ~ - ~ 2 0 k G y ~}$ & $5 \pm 0,5$ & $308 \pm 3,6$ & 2,1 \\
\hline $\mathbf{2}$ - 1159 - Não & $4,3 \pm 0,4$ & $135 \pm 2,1$ & 2,5 \\
\hline irradiado & & & 1,4 \\
\hline $\mathbf{2}$ - 1159 - 5kGy & $3,2 \pm 0,7$ & $211 \pm 4,1$ & 1,5 \\
\hline $\mathbf{2 1 1 5 9}$ - 10kGy & $3,3 \pm 0,7$ & $250 \pm 1,2$ & 1,8 \\
\hline
\end{tabular}

Na TAB. 13 estão descritos os resultados obtidos após a avaliação das propriedades mecânicas dos filmes FKM incorporados com POSS 1160. As amostras incorporadas com $2 \%$ desta nanopartícula apresentaram comportamentos muito parecidos em todas as doses irradiadas. As amostras irradiadas tiveram uma diminuição no alongamento em relação ao não irradiado e também não houve variação significante dos valores de módulo a $25 \%$ entre essas amostras. Uma das aplicações indicadas pelo fabricante desta nanopartícula é como agente de reticulação, portanto, este fato pode estar 
atribuído à maior quantidade de POSS incorporado que protegeu a cadeia polimérica, diminuindo o efeito de degradação causado pela irradiação após a vulcanização.

TABELA 13 - Valores de tensão e alongamento na ruptura para os filmes FKM incorporados com POSS 1160 vulcanizados antes da irradiação e não irradiado.

\begin{tabular}{|c|c|c|c|}
\hline Filme & $\begin{array}{c}\text { Tensão na } \\
\text { ruptura / MPa }\end{array}$ & $\begin{array}{l}\text { Alongamento } \\
\text { na ruptura / \% }\end{array}$ & $\begin{array}{c}\text { Módulo a } \\
25 \%\end{array}$ \\
\hline $\begin{array}{l}\text { 0,5 - } 1160 \text {-Não } \\
\text { irradiado }\end{array}$ & $10,2 \pm 0,6$ & $185 \pm 1,6$ & 4,7 \\
\hline $0,5-1160-5 k G y$ & $4,7 \pm 1,1$ & $236 \pm 4,5$ & 2,0 \\
\hline $0,5-1160-10 k G y$ & $5,7 \pm 0,4$ & $278 \pm 1,2$ & 2,3 \\
\hline $0,5-1160$ - 20kGy & $3,4 \pm 0,1$ & $168 \pm 1,2$ & 1,8 \\
\hline $\begin{array}{c}1 \text { - } 1160 \text { - Não } \\
\text { irradiado }\end{array}$ & $5,7 \pm 0,7$ & $177 \pm 3,9$ & 2,7 \\
\hline 1 - 1160 - 5kGy & $5,2 \pm 0,5$ & $191 \pm 1,7$ & 3,1 \\
\hline 1 - 1160 - 10kGy & $4 \pm 0,2$ & $168 \pm 1,8$ & 3,1 \\
\hline 1 - 1160 - 20kGy & $4,4 \pm 1,1$ & $189 \pm 4,3$ & 3,1 \\
\hline $\begin{array}{c}2 \text { - } 1160 \text { - Não } \\
\text { irradiado }\end{array}$ & $6 \pm 0,4$ & $218 \pm 0,9$ & 2,7 \\
\hline $2-1160-5 k G y$ & $5,4 \pm 1,4$ & $138 \pm 2,8$ & 3,0 \\
\hline $2-1160-10 k G y$ & $5,3 \pm 0,6$ & $188 \pm 1,8$ & 2,7 \\
\hline $2-1160-20 k G y$ & $4,8 \pm 1,2$ & $193 \pm 1,2$ & 2,6 \\
\hline
\end{tabular}

Na TAB.14 estão descritos os resultados obtidos após a análise das propriedades mecânicas dos filmes FKM incorporados com POSS 1163. A nanopartícula POSS 1163 é indicada pelo fabricante como agente de reticulação específico para borracha e após a avaliação dos resultados mecânicos, verificouse que esta nanopartícula protegeu a cadeia polimérica do efeito da degradação 
por irradiação mesmo com a incorporação de pequena quantidade $(0,5$ e 1\%) de carga. A diminuição do efeito da degradação foi confirmada pela diminuição dos valores de alongamento na ruptura.

TABELA 14 - Valores de tensão e alongamento na ruptura para os filmes FKM incorporados com POSS 1163, vulcanizados antes da irradiação e não irradiado.

\begin{tabular}{|c|c|c|c|}
\hline Filme & $\begin{array}{c}\text { Tensão na } \\
\text { ruptura / MPa }\end{array}$ & $\begin{array}{l}\text { Alongamento } \\
\text { na ruptura / \% }\end{array}$ & $\begin{array}{c}\text { Módulo a } \\
25 \%\end{array}$ \\
\hline $\begin{array}{c}0,5 \text { - } 1163 \text { - Não } \\
\text { irradiado }\end{array}$ & $6 \pm 1,1$ & $306 \pm 1,0$ & 2,1 \\
\hline 0,5 - 1163 - 5kGy & $6,2 \pm 1,0$ & $243 \pm 2,7$ & 2,4 \\
\hline 0,5 - 1163 - 10kGy & $5 \pm 0,2$ & $279 \pm 3,7$ & 1,8 \\
\hline 0,5 - 1163 - 20kGy & $6,1 \pm 0,6$ & $250 \pm 2,4$ & 2,7 \\
\hline $\begin{array}{c}1 \text { - } 1163 \text { - Não } \\
\text { irradiado }\end{array}$ & $4,9 \pm 0,6$ & $271 \pm 3,2$ & 2,1 \\
\hline 1 - 1163 - 5kGy & $4,3 \pm 1,1$ & $171 \pm 3,5$ & 1,7 \\
\hline 1 - 1163 - 10kGy & $5,4 \pm 0,1$ & $259 \pm 2,5$ & 1,9 \\
\hline 1 - 1163 - 20kGy & $6,9 \pm 0,9$ & $271 \pm 2,0$ & 2,5 \\
\hline $\begin{array}{c}2 \text { - } 1163 \text { - Não } \\
\text { irradiado }\end{array}$ & $4,3 \pm 0,3$ & $180 \pm 1,6$ & 1,9 \\
\hline 2 - 1163 - 5kGy & $4 \pm 0,9$ & $232 \pm 1,9$ & 2,0 \\
\hline 2 - 1163 - 10kGy & $6 \pm 1,5$ & $265 \pm 1,5$ & 2,1 \\
\hline 2 - 1163 - 20kGy & $4,7 \pm 1,1$ & $244 \pm 1,2$ & 2,7 \\
\hline
\end{tabular}

Os resultados obtidos após o ensaio de dureza estão representados nas FIG. 39 a 42. A dureza também é uma propriedade que depende da mobilidade da cadeia polimérica. O aumento da dureza indica maior rigidez do material que pode ter ocorrido devido à presença de reações do oxigênio na superfície do FKM. 


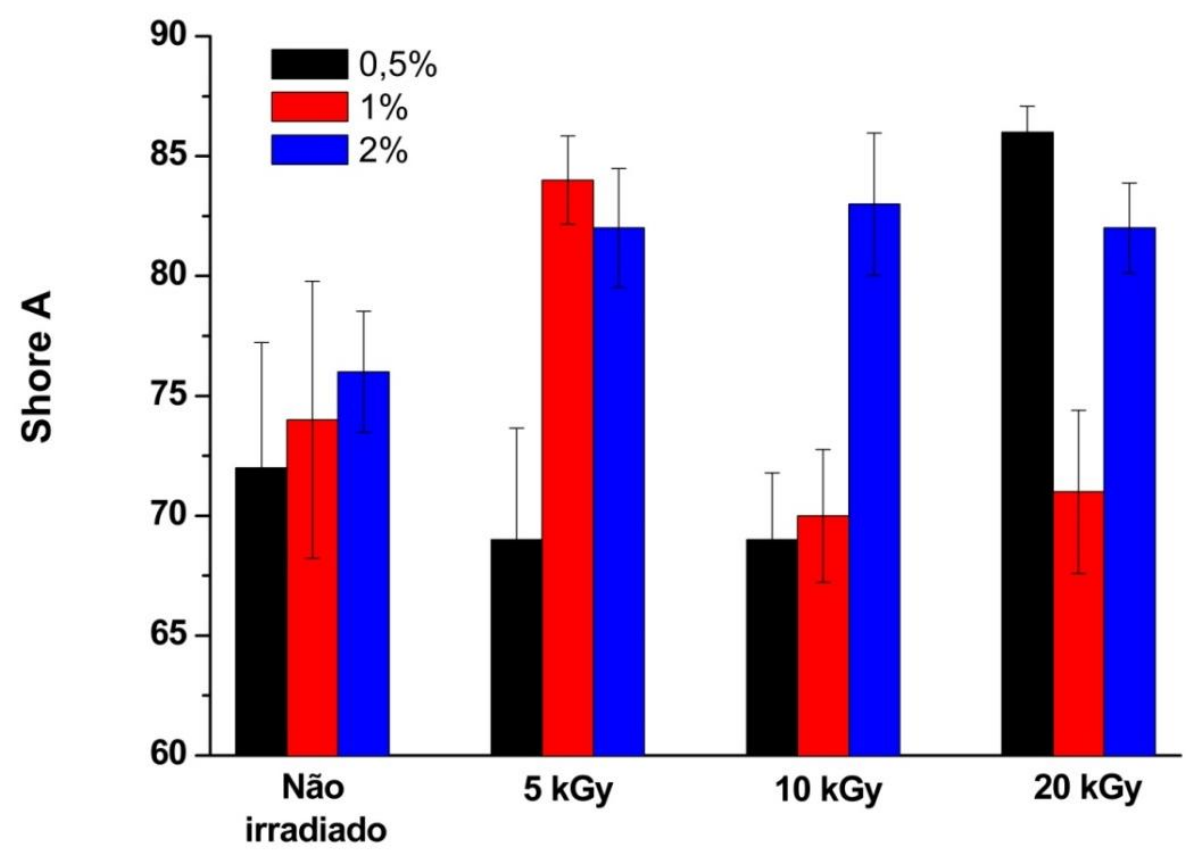

FIGURA 39 - Resultado do ensaio de dureza dos filmes FKM incorporados com argila Cloisite 15A, vulcanizados antes da irradiação e não irradiado.

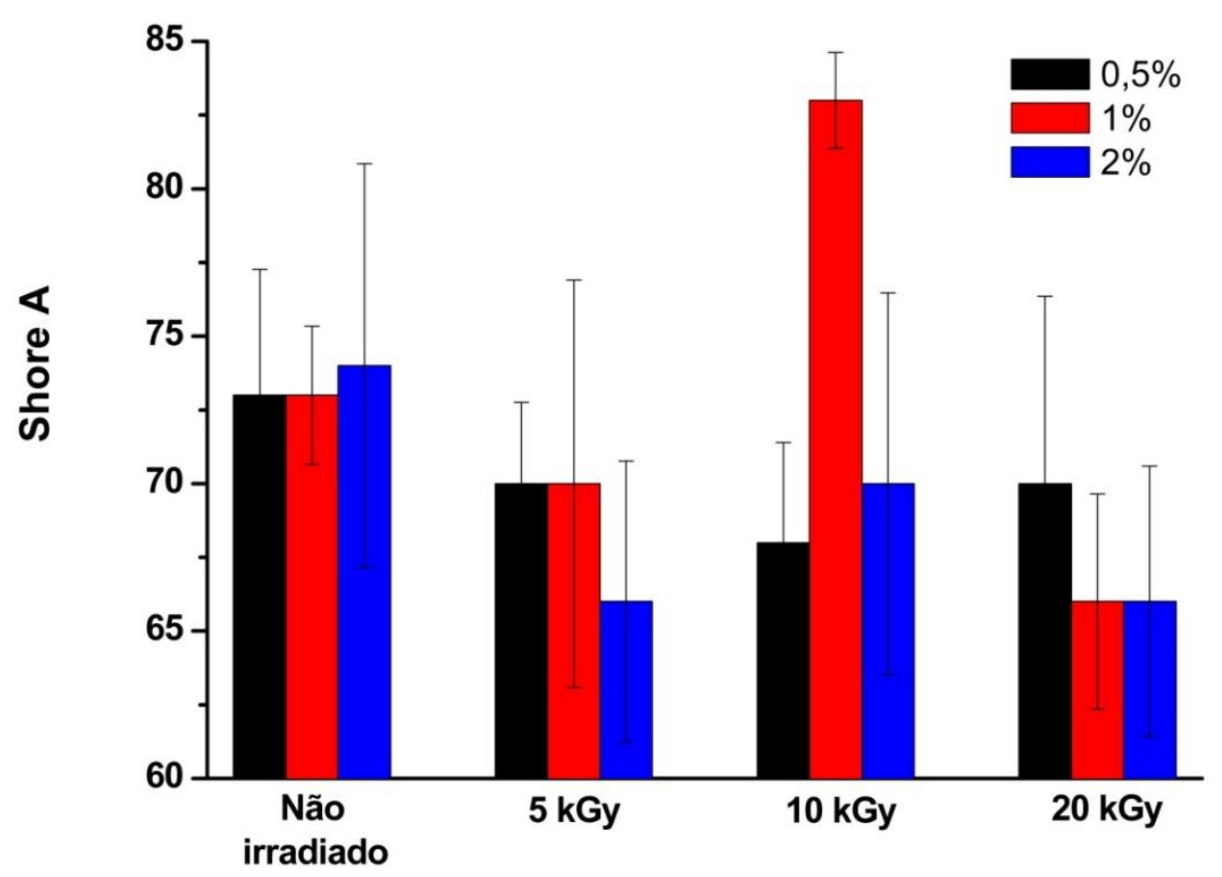

FIGURA 40 - Resultado do ensaio de dureza dos filmes FKM incorporados com POSS 1159, vulcanizados antes da irradiação e não irradiado. 


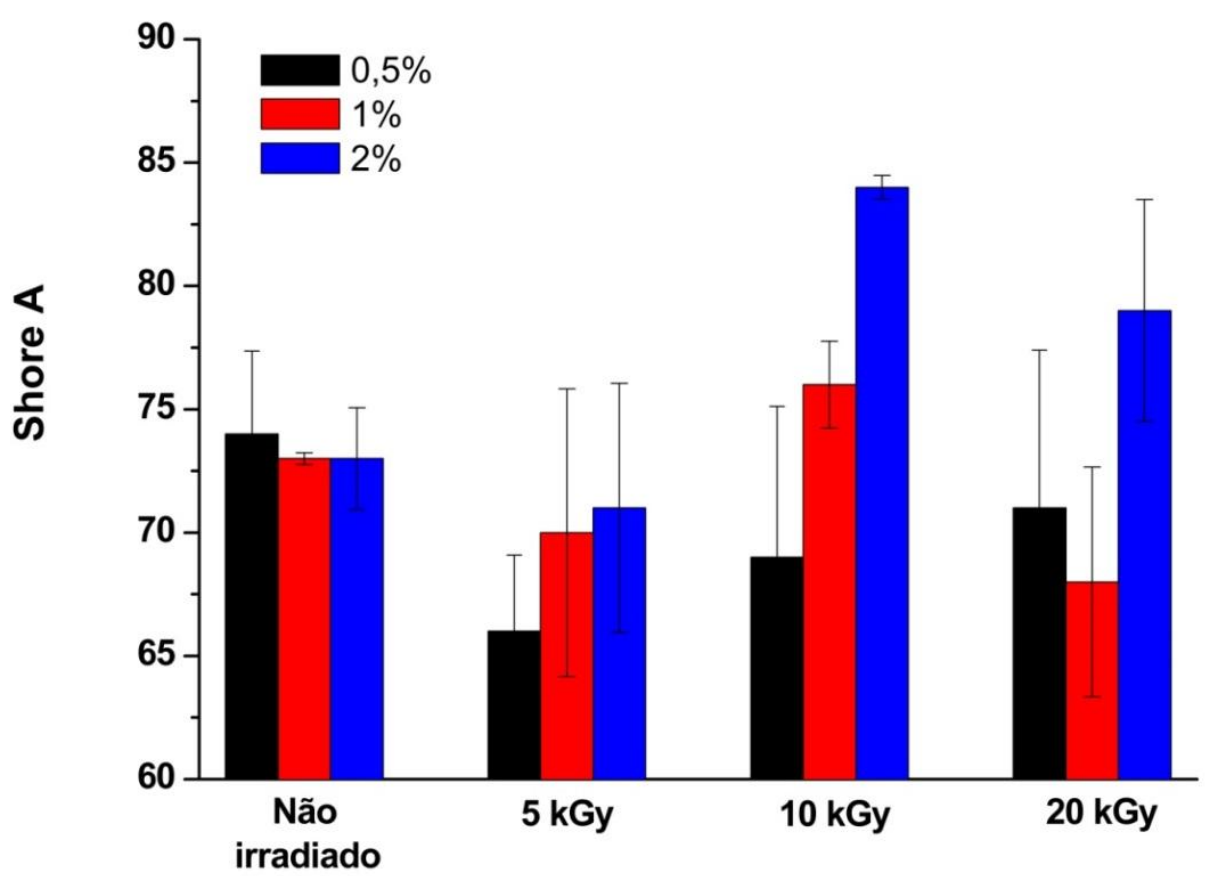

FIGURA 41 - Resultado do ensaio de dureza dos filmes FKM incorporados com POSS 1160, vulcanizados antes da irradiação e não irradiado.

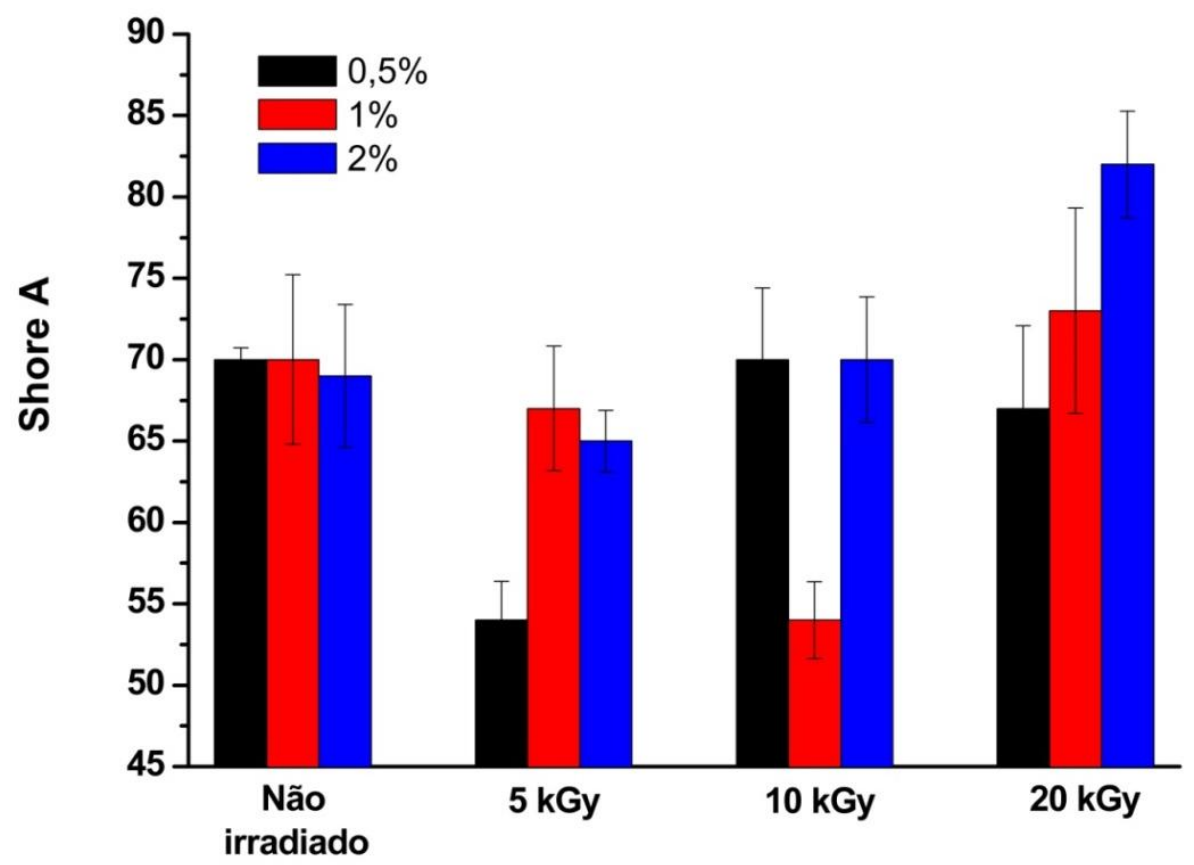

FIGURA 42 - Resultado do ensaio de dureza dos filmes FKM incorporados com POSS 1163, vulcanizados antes da irradiação e não irradiado. 
Nas FIG. 43 e 44 estão representados os resultados de intumescimento em MEK para os filmes incorporados com argila Cloisite 15A e POSS 1159, respectivamente. O aumento do intumescimento foi verificado em todos os filmes irradiados quando comparados ao filme não irradiado. Nestas amostras foi observado aumento de mais de $15 \%$ nos valores de intumescimento, este aumento está diretamente relacionado com o efeito da degradação da cadeia polimérica em decorrência da irradiação, o que está coerente com os resultados obtidos na análise das propriedades mecânicas.

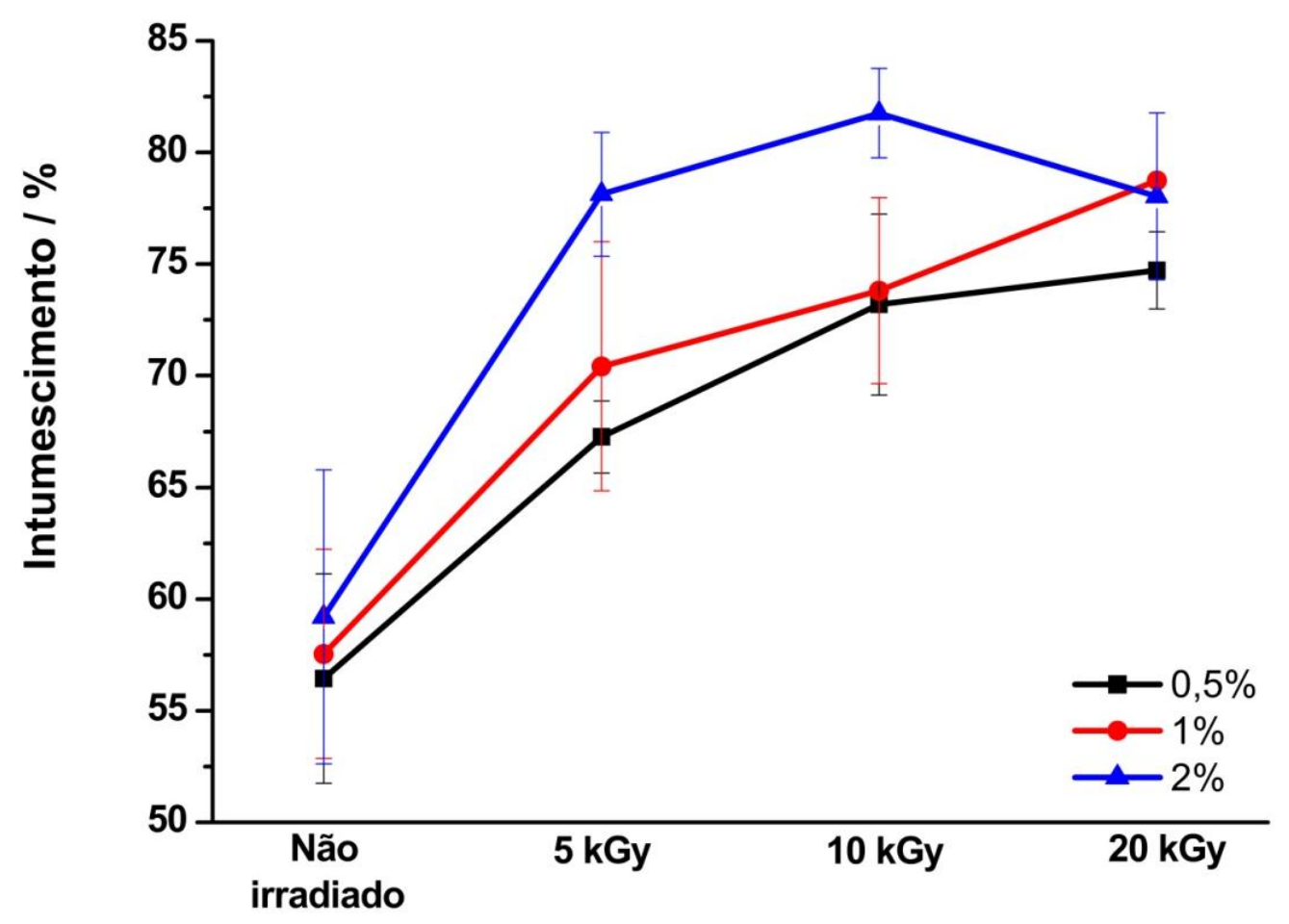

FIGURA 43 - Resultado do teste de intumescimento em MEK dos filmes FKM incorporados com argila Cloisite $15 \mathrm{~A}$ vulcanizados antes da irradiação e não irradiado. 


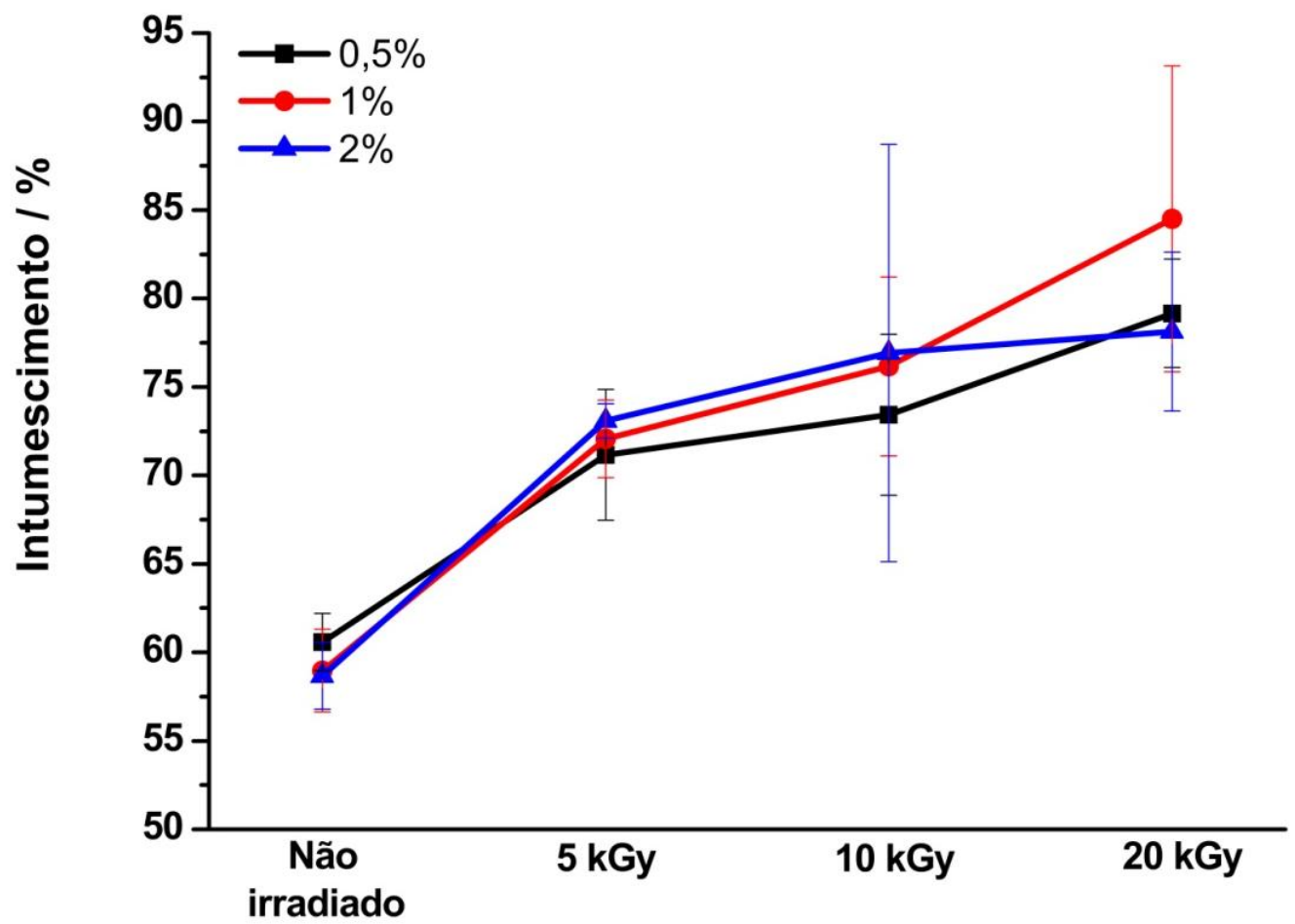

FIGURA 44 - Resultado do teste de intumescimento em MEK dos filmes FKM incorporados com POSS 1159 vulcanizados antes da irradiação e não irradiado.

Nas FIG. 45 e 46 estão representados os resultados obtidos para os filmes incorporados com POSS 1160 e 1163, respectivamente, que foram imersos em MEK. Os valores de intumescimento das amostras irradiadas foram maiores quando comparados com a não irradiada. Porém o aumento do intumescimento foi de menor intensidade quando comparado com as duas outras nanopartículas, visto o efeito de proteção da cadeia polimérica realizado pelas nanopartículas POSS 1160 e POSS 1163, corroborando os resultados obtidos de análise mecânica. 


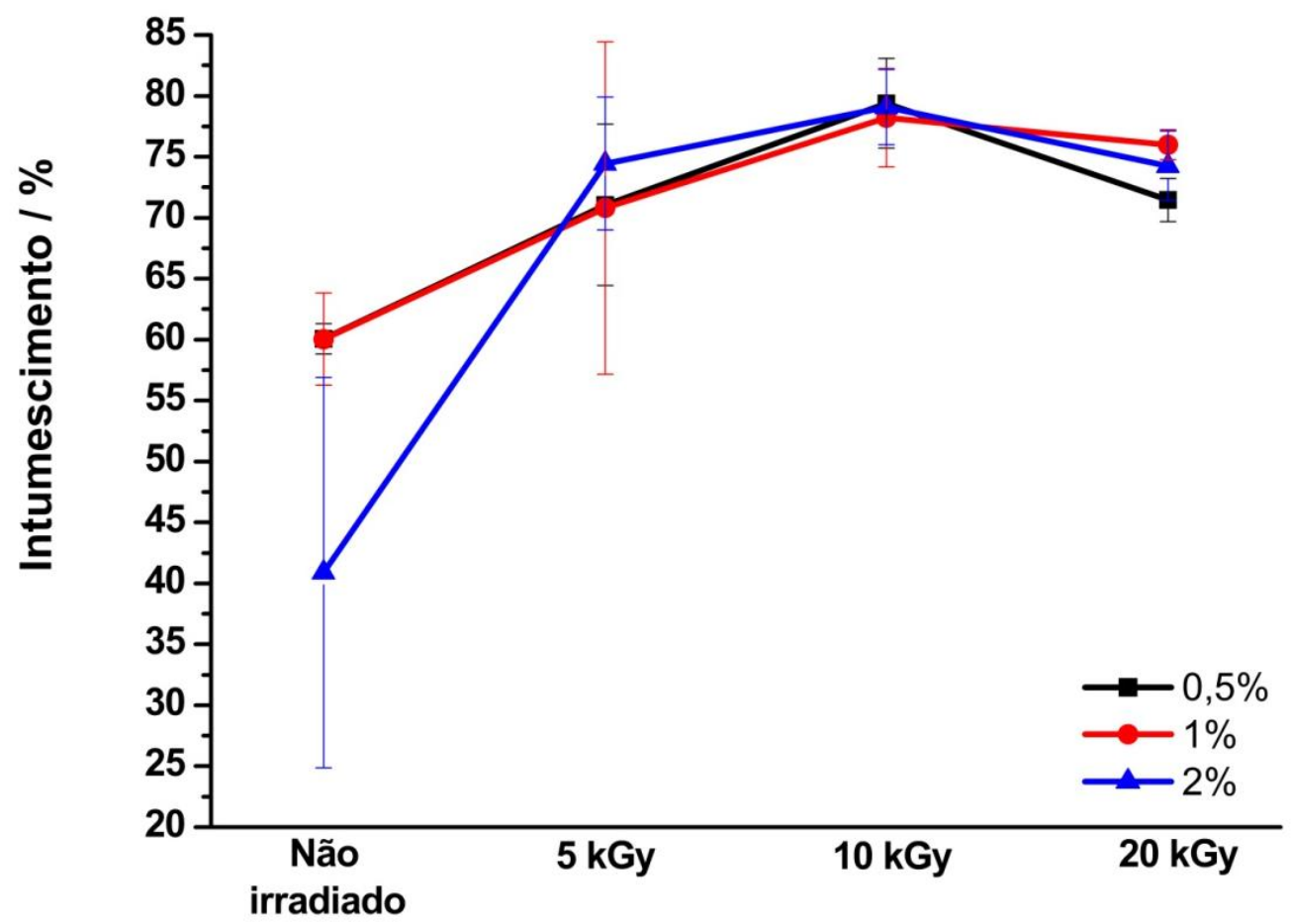

FIGURA 45 - Resultado do teste de intumescimento em MEK dos filmes FKM incorporados com POSS 1160, vulcanizados antes da irradiação e não irradiado.

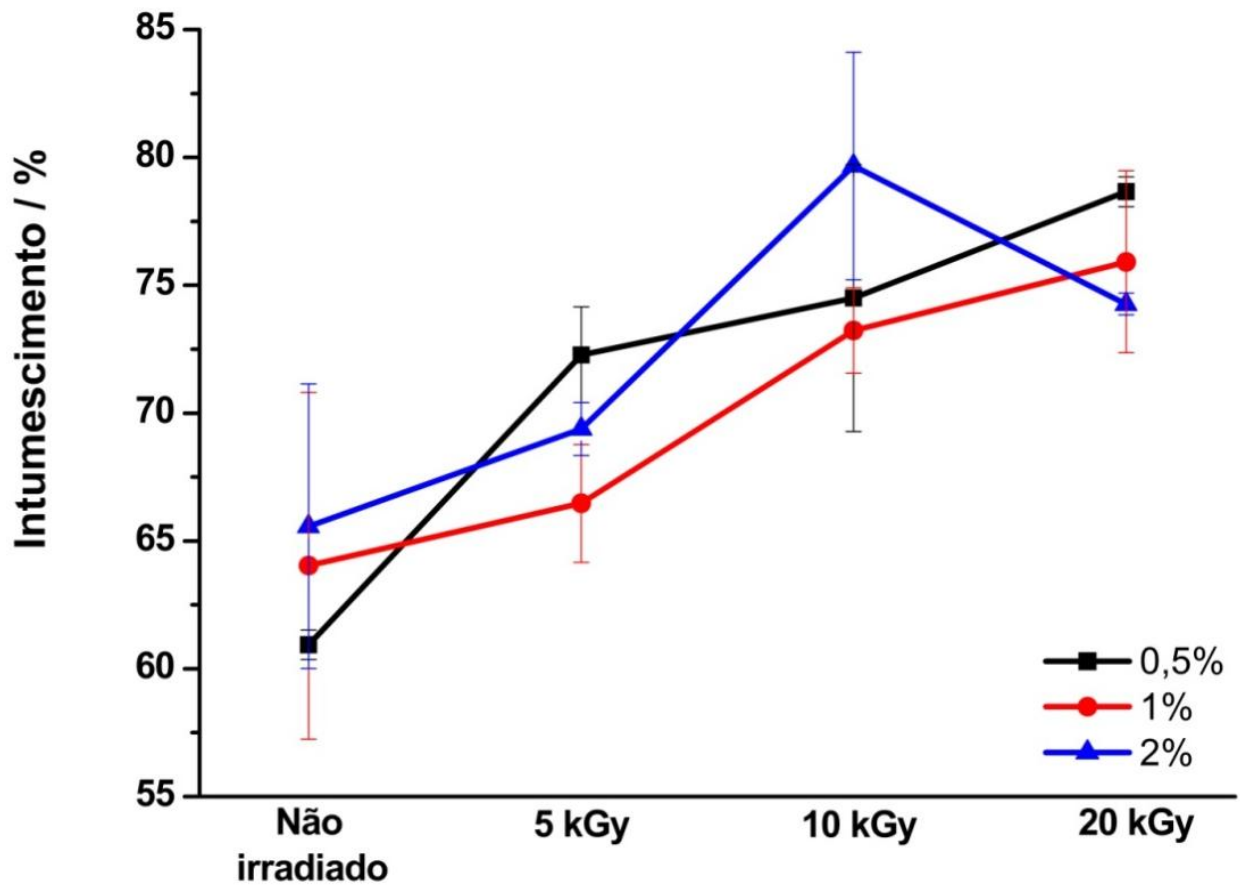

FIGURA 46 - Resultado do teste de intumescimento em MEK dos filmes FKM incorporados com POSS 1163 vulcanizados antes da irradiação e não irradiado. 
As imagens de microscopia eletrônica de varredura foram obtidas com aumento de 1000x. Os filmes FKM incorporados com nanopartícula não irradiados e irradiados a 10 e 20kGy estão reportadas nas FIG. 47 a 50. As amostras incorporadas com argila Cloisite 15A estão representadas na FIG. 47 e o efeito da irradiação foi observado nas amostras irradiadas devido à degradação superficial destes filmes.
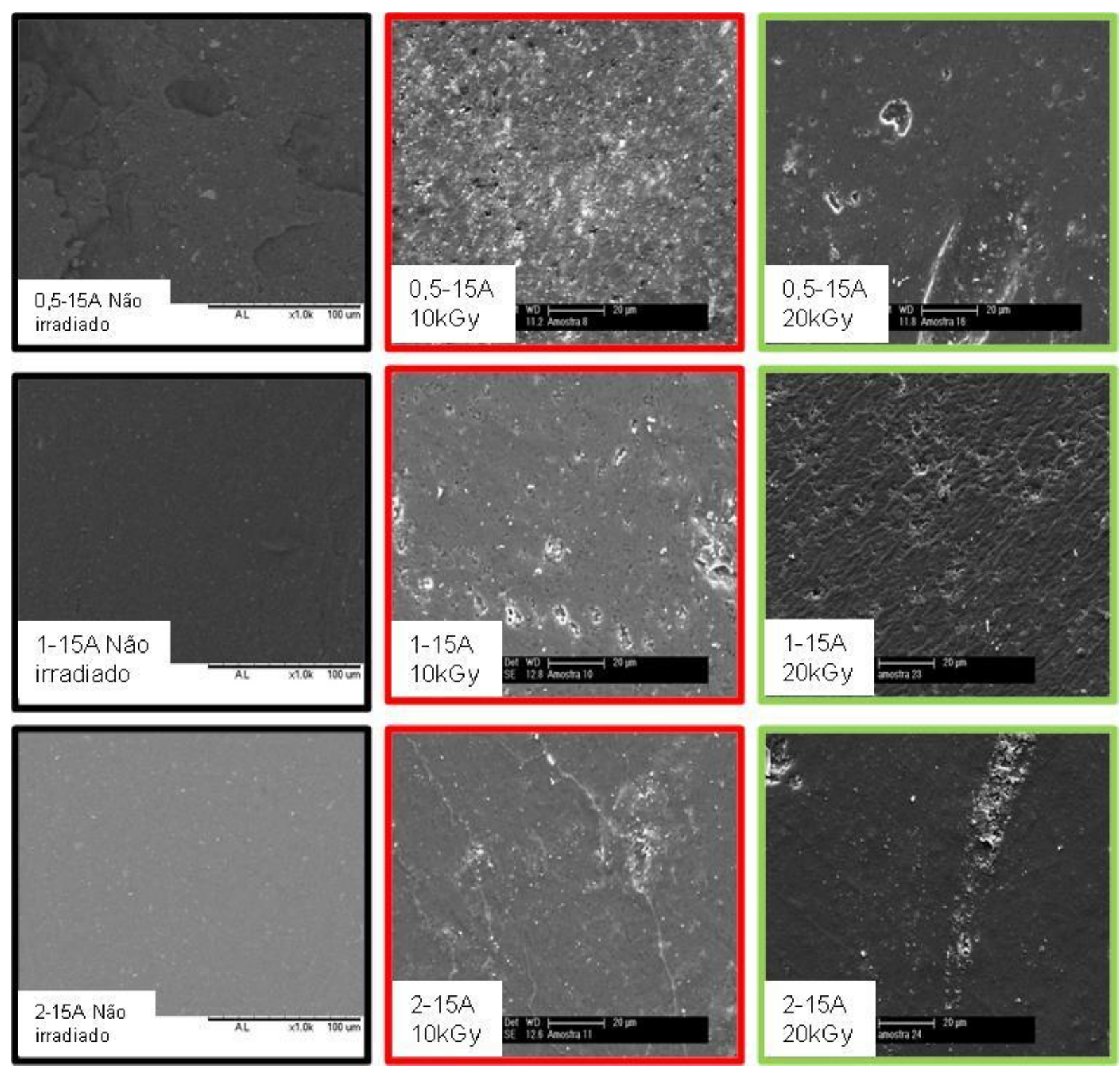

FIGURA 47 - Imagens de microscopia eletrônica de varredura dos filmes FKM incorporados com argila Cloisite 15A vulcanizados antes da irradiação e não irradiado. 
As imagens de microscopia dos filmes FKM incorporados com POSS 1159 estão representadas na FIG. 48. A degradação superficial foi observada nos filmes em decorrência da irradiação a 10 e 20kGy e confirmaram os resultados obtidos pela análise mecânica.
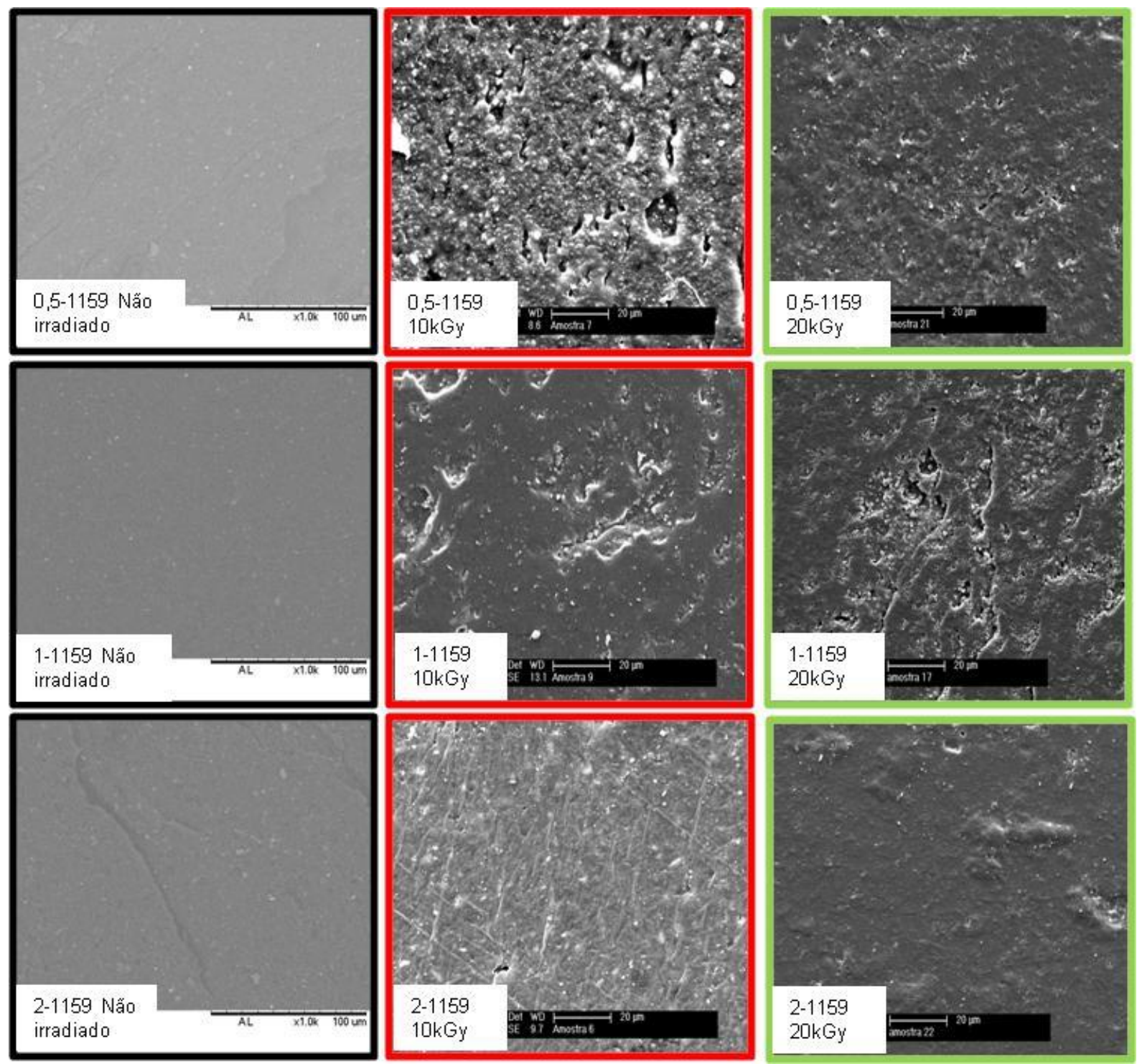

FIGURA 48 - Imagens de microscopia eletrônica de varredura dos filmes FKM incorporados com POSS 1159 vulcanizados antes da irradiação e não irradiado. 
As imagens de microscopia dos filmes FKM incorporados com POSS 1160 estão representadas na FIG. 49. A degradação superficial foi observada nos filmes em decorrência da irradiação a 10 e 20kGy, com o aparecimento de buracos e rachaduras na superfície dos filmes.
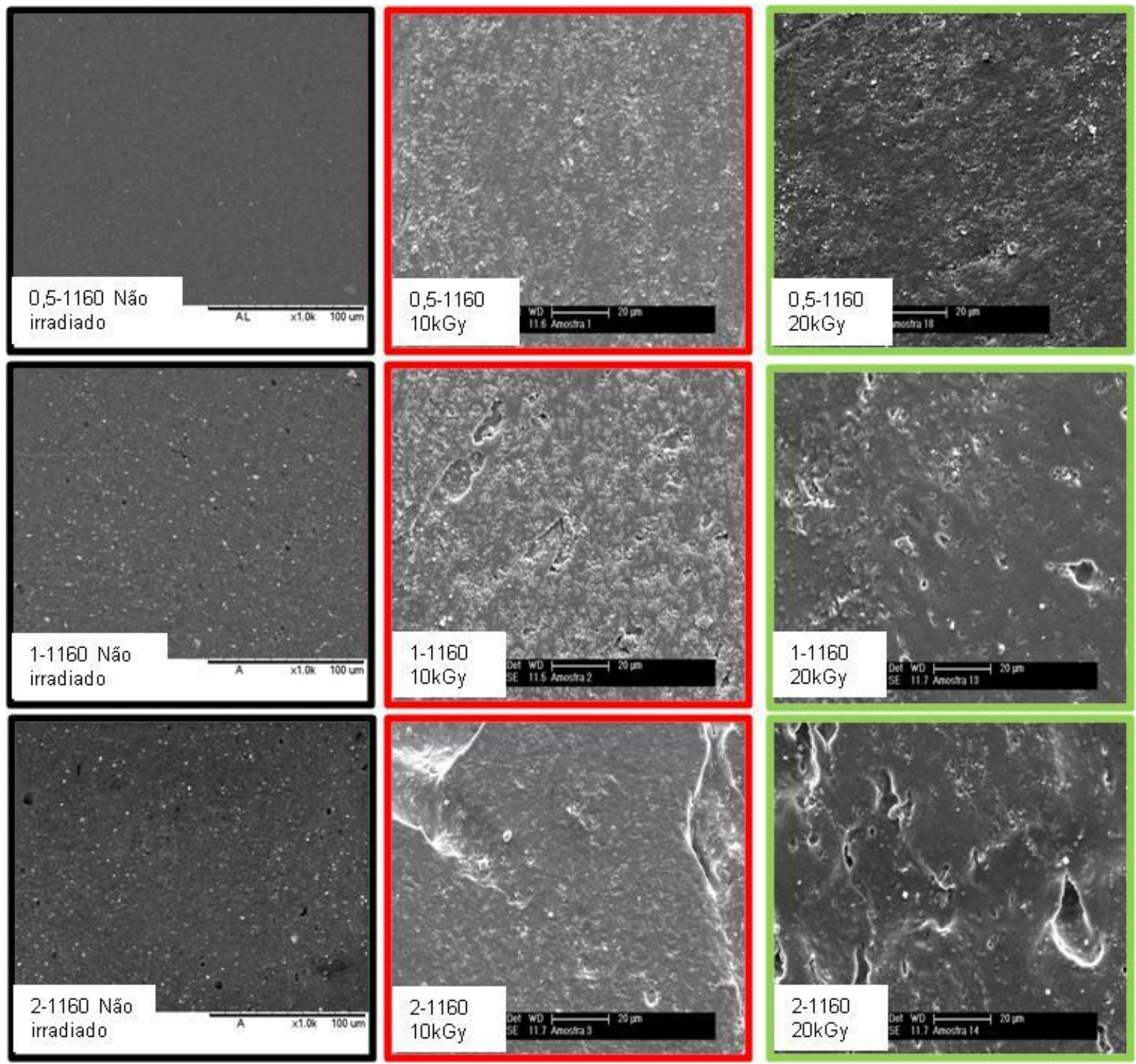

FIGURA 49 - Imagens de microscopia eletrônica de varredura dos filmes FKM incorporados com POSS 1160 vulcanizados antes da irradiação e não irradiado. 
As imagens de microscopia dos filmes FKM incorporados com POSS 1163 estão representadas na FIG. 50. A degradação superficial foi observada nos filmes em decorrência da irradiação a 10 e 20kGy, com o aparecimento de rachaduras e tortuosidades superficiais. A amostra incorporada com 1\% e irradiada a 20kGy foi a que apresentou modificação total em sua superfície.
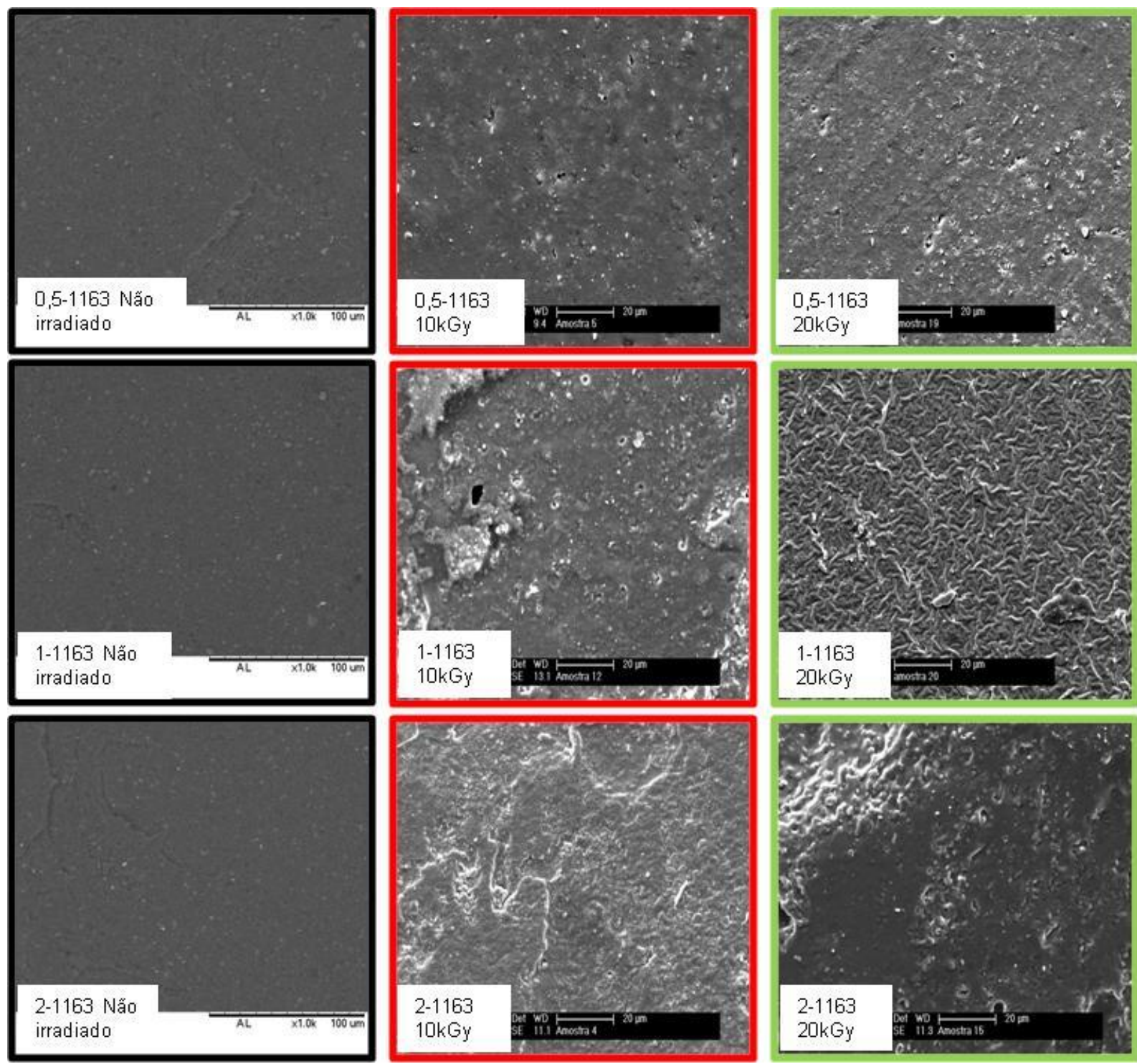

FIGURA 50 - Imagens de microscopia eletrônica de varredura dos filmes FKM incorporados com POSS 1163 vulcanizados antes da irradiação e não irradiado. 


\subsection{Efeito da radiação ionizante nos filmes de nanocompósitos antes do processo de vulcanização}

A incorporação de cargas está diretamente relacionada com a variação do volume e consequente mobilidade da cadeia polimérica. O volume ocupado pela carga devido à interação carga-elastômero afeta diretamente as propriedades mecânicas da cadeia polimérica. A incorporação de cargas na composição da borracha contribui para alterar o volume da cadeia polimérica, essa alteração é devido à interação hidrodinâmica, que é baseada na variação da viscosidade do polímero pela adição de partículas [115 - 117].

O modelo descrito por Witten [118] para as propriedades de tensão $x$ deformação nas borrachas reforçadas com cargas relata uma compressão lateral dos grupos agregados. O reforço com negro de fumo é conhecido por atuar como reforço mecânico mesmo em pequena quantidade no composto de borracha, este reforço é atribuído à estrutura ramificada desta carga na cadeia polimérica e pela forte interação com o polímero.

Alongamento é a habilidade da borracha vulcanizada de estirar sem romper. Todas as borrachas são formadas por cadeia de hidrocarbonetos que contem um grande número de átomos de carbono formando a estrutura da cadeia polimérica. Quando uma força é aplicada na direção uniaxial estas cadeias tendem a se endireitar (alongar). Entretanto, a extensão que essas cadeias estiram é limitada pelo ângulo da ligação C-F. A presença de pequenas partículas sólidas na borracha altera o campo de tensões, aumentam a tensão local das cadeiras ocasionando heterogeneidade nestes locais. As propriedades mecânicas destes materiais dependem da topologia superficial da carga e da adsorção destas cargas pela cadeia polimérica. Com a adição de carga na borracha o espaço livre (volume vazio) no material é preenchido, o que reduz o movimento das cadeias e seu alongamento. O aumento da quantidade de carga pode acarretar no aumento da área específica, aprisionando as extremidades livres da cadeia polimérica o que aumenta a imobilização desta cadeia. Além disso, a interface polímero-carga possui forte ligação de hidrogênio, que pode-se assumir 
que pedaços de segmentos da cadeia polimérica estão ancoradas na superfície da partícula, o que também reduz a mobilidade [119].

A incorporação de nanopartícula rígida em uma matriz polimérica flexível resulta em aumento do módulo de Young [120, 121]. Esse fato pode ser observado para os valores do módulo a $25 \%$, que aumentaram com a incorporação da nanopartícula conforme foram relatados nas TAB. 15 a 18.

Ao comparar os resultados obtidos para os filmes irradiados e o filme não irradiado foi verificado um aumento na tensão de ruptura em função da dose irradiada; enquanto que os valores de alongamento na ruptura tiveram um comportamento oposto, houve diminuição deste valor com o aumento da dose irradiada. Este comportamento está relacionado com a prévia reticulação das amostras, pois durante a irradiação pode ser iniciado o processo de cura (vulcanização) da borracha, aumentando a quantidade de radicais livres que favorece o aumento da reticulação pela interação da radiação com a amostra e pelo processo de vulcanização. Por causa do aumento da reticulação da cadeia ocorreu a diminuição do alongamento da cadeia e o aumento do módulo. Os valores de tensão e de alongamento na ruptura estão descritos na TAB. 15 a 18 .

A adição de pequena quantidade de argila organofílica (montmorilonita) em FKM pode resultar em melhora de propriedade mecânica devido à forte interação polímero-carga. Porém ao aumentar a quantidade de argila incorporada, aumenta-se também a interação polímero-carga o que ocasiona a redução da mobilidade da cadeia polimérica, resultando em aumento da tensão e diminuição do alongamento [122, 123]. Este fato foi observado para os filmes incorporados com $0,5 \%$ e $1 \%$ de argila que apresentaram diminuição do alongamento e aumento do módulo (TAB. 15).

Para os filmes incorporados com $2 \%$ de argila (TAB.15) e vulcanizados após a irradiação verificou-se que a maior quantidade de argila incorporada contribuiu para a diminuição da mobilidade da cadeia polimérica resultando em aumento de tensão até a ruptura do material. Entretanto, o efeito da degradação 
pelo processo de irradiação foi determinante para o aumento do alongamento destas amostras.

TABELA 15 - Valores de tensão e alongamento na ruptura para os filmes FKM incorporados com argila Cloisite 15A, vulcanizados após a irradiação e não irradiado.

\begin{tabular}{|c|c|c|c|}
\hline Filme & $\begin{array}{c}\text { Tensão na } \\
\text { ruptura / MPa }\end{array}$ & $\begin{array}{l}\text { Alongamento } \\
\text { na ruptura / \% }\end{array}$ & $\begin{array}{c}\text { Módulo a } \\
25 \%\end{array}$ \\
\hline $\begin{array}{c}\text { 0,5 - 15A - Não } \\
\text { irradiado }\end{array}$ & $7,3 \pm 1,9$ & $335 \pm 1,23$ & 2,5 \\
\hline 0,5 - 15A - 5kGy & $8 \pm 1,3$ & $200 \pm 1,5$ & 3,2 \\
\hline 0,5 - 15A - 10kGy & $8,1 \pm 1,1$ & $165 \pm 1,1$ & 2,7 \\
\hline 0,5 - 15A - 20kGy & $16 \pm 1,1$ & $136 \pm 2,4$ & 4,5 \\
\hline $\begin{array}{c}1 \text { - 15A - Não } \\
\text { irradiado }\end{array}$ & $3,5 \pm 0,9$ & $190 \pm 3,9$ & 1,7 \\
\hline 1 - 15A - 5kGy & $8,5 \pm 1,2$ & $229 \pm 3,9$ & 3,2 \\
\hline 1 - 15A - 10kGy & $15,5 \pm 0,8$ & $119 \pm 1,1$ & 4,0 \\
\hline 1 - 15A - 20kGy & $15,4 \pm 1,1$ & $105 \pm 1,3$ & 5,0 \\
\hline $\begin{array}{c}2 \text { - 15A - Não } \\
\text { irradiado }\end{array}$ & $4,7 \pm 0,7$ & $83 \pm 1,1$ & 3,1 \\
\hline 2 - 15A - 5kGy & $8,7 \pm 1,4$ & $168 \pm 1,1$ & 3,7 \\
\hline 2 - 15A - 10kGy & $10,3 \pm 2,1$ & $100 \pm 2,0$ & 3,8 \\
\hline 2 - 15A - 20kGy & $25,2 \pm 2,1$ & $121 \pm 1,1$ & 5,5 \\
\hline
\end{tabular}

$\mathrm{Na}$ TAB.16 estão descritos os valores de tensão e alongamento obtidos após análise dos filmes incorporados com POSS 1159 vulcanizados após a irradiação. As amostras incorporadas com 0,5 e $1 \%$ e irradiadas obtiveram valores de alongamento inferiores e de módulo superiores ao da amostra não irradiada, indicando a predominância da reticulação da matriz polimérica. 
As amostras incorporadas com $2 \%$ de nanopartícula e irradiadas a 5 e 10kGy apresentaram aumento do alongamento em relação à amostra não irradiada, indicando uma tendência à degradação da cadeia polimérica. Esta degradação pode estar associada degradação por oxidação da matriz polimérica, pois os radicais formados durante a radiação não recombinaram entre si devido a baixa mobilidade da cadeia pela presença da nanopartícula. Como não houve essa recombinação os radicais formados reagiram com o oxigênio presente no ar causando a degradação oxidativa.

TABELA 16 - Valores de tensão e alongamento na ruptura para os filmes FKM incorporados com POSS 1159, vulcanizados após a irradiação e não irradiado.

\begin{tabular}{c|c|c|c}
\hline Filme & $\begin{array}{c}\text { Tensão na } \\
\text { ruptura / MPa }\end{array}$ & $\begin{array}{c}\text { Alongamento } \\
\text { na ruptura / } \%\end{array}$ & $\begin{array}{c}\text { Módulo a } \\
\mathbf{2 5 \%}\end{array}$ \\
\hline $\begin{array}{c}\mathbf{0 , 5} \text { - 1159 - Não } \\
\text { irradiado }\end{array}$ & $8,3 \pm 2,1$ & $330 \pm 1,1$ & 3,0 \\
\hline $\mathbf{0 , 5}$ - 1159 - 5kGy & $8,2 \pm 1,9$ & $209 \pm 2,2$ & 3,3 \\
\hline $\mathbf{0 , 5}$ - 1159 - 10kGy & $10 \pm 1,4$ & $169 \pm 1,8$ & 3,6 \\
\hline $\mathbf{0 , 5}$ - 1159 - 20kGy & $17,2 \pm 2,4$ & $93 \pm 4,1$ & 4,7 \\
\hline $\begin{array}{c}\text { 1 - 1159 - Não } \\
\text { irradiado }\end{array}$ & $4,6 \pm 0,4$ & $316 \pm 4,3$ & 2,8 \\
\hline $\mathbf{1}$ - 1159 - 5kGy & $8,4 \pm 0,2$ & $255 \pm 4,4$ & 3,5 \\
\hline $\mathbf{1 ~ - 1 1 5 9 ~ - ~ 1 0 k G y ~}$ & $7,7 \pm 1,4$ & $200 \pm 2,5$ & 4,3 \\
\hline $\mathbf{1}$ - 1159 - 20kGy & $8 \pm 2,3$ & $113 \pm 1,3$ & 3,2 \\
\hline $\mathbf{2}$ - 1159 - Não & $4,3 \pm 0,4$ & $135 \pm 2,1$ & 2,4 \\
\hline irradiado & & & 3,3 \\
\hline $\mathbf{2}$ - 1159 - 5kGy & $8,4 \pm 0,2$ & $255 \pm 4,4$ & 3,3 \\
\hline $\mathbf{2}$ - 1159 - 10kGy & $7,7 \pm 1,4$ & $200 \pm 2,5$ & 3,9 \\
\hline $\mathbf{2}$ - 1159 - 20kGy & $8 \pm 2,3$ & $113 \pm 1,3$ & \\
\hline
\end{tabular}


Na TAB. 17 estão descritos os valores de tensão e alongamento para as amostras incorporadas com POSS 1160 vulcanizadas após a irradiação. Todas as amostras processadas com esta nanopartícula apresentaram diminuição do alongamento e aumento do módulo, confirmando a predominância da reticulação da cadeia polimérica, mesmo após o processo de irradiação.

TABELA 17 - Valores de tensão e alongamento na ruptura para os filmes FKM incorporados com POSS 1160, vulcanizados após a irradiação e não irradiado.

\begin{tabular}{|c|c|c|c|}
\hline Filme & $\begin{array}{c}\text { Tensão na } \\
\text { ruptura / MPa }\end{array}$ & $\begin{array}{l}\text { Alongamento } \\
\text { na ruptura / \% }\end{array}$ & $\begin{array}{c}\text { Módulo a } \\
25 \%\end{array}$ \\
\hline $\begin{array}{c}0,5 \text { - } 1160 \text { - Não } \\
\text { irradiado }\end{array}$ & $10,2 \pm 0,6$ & $185 \pm 1,6$ & 4,7 \\
\hline $0,5-1160-5 k G y$ & $6,2 \pm 0,6$ & $161 \pm 1,5$ & 2,8 \\
\hline $0,5-1160$ - 10kGy & $12,4 \pm 0,7$ & $131 \pm 2,4$ & 4,1 \\
\hline $0,5-1160$ - 20kGy & $16,6 \pm 1,1$ & $89 \pm 3,2$ & 4,5 \\
\hline $\begin{array}{c}1 \text { - } 1160 \text { - Não } \\
\text { irradiado }\end{array}$ & $5,7 \pm 0,7$ & $177 \pm 3,9$ & 1,7 \\
\hline $1-1160-5 k G y$ & $8 \pm 0,5$ & $162 \pm 2,3$ & 2,9 \\
\hline 1 - 1160 - 10kGy & $8 \pm 1,4$ & $85 \pm 3,1$ & 2,8 \\
\hline 1 - 1160 - 20kGy & $10,2 \pm 0,9$ & $85 \pm 1,8$ & 2,6 \\
\hline $\begin{array}{c}2 \text { - } 1160 \text { - Não } \\
\text { irradiado }\end{array}$ & $6 \pm 0,4$ & $218 \pm 0,9$ & 2,8 \\
\hline $2-1160-5 k G y$ & $4,4 \pm 1,5$ & $131 \pm 2,6$ & 2,2 \\
\hline $2-1160-10 k G y$ & $13 \pm 1,2$ & $139 \pm 1,1$ & 4,9 \\
\hline $2-1160-20 k G y$ & $13,5 \pm 0,6$ & $99 \pm 1,9$ & 4,3 \\
\hline
\end{tabular}


$\mathrm{Na}$ TAB. 18 estão descritos os valores de tensão e alongamento para as amostras incorporadas com POSS 1163 vulcanizadas após a irradiação. Todas as amostras processadas com esta nanopartícula apresentaram o mesmo comportamento das amostras incorporadas com POSS 1160 diminuição do alongamento e aumento do módulo, confirmando a predominância da reticulação da cadeia polimérica, mesmo após o processo de irradiação.

TABELA 18 - Valores de tensão e alongamento na ruptura para os filmes FKM incorporados com POSS 1163, vulcanizados após a irradiação e não irradiado.

\begin{tabular}{|c|c|c|c|}
\hline Filme & $\begin{array}{c}\text { Tensão na } \\
\text { ruptura / MPa }\end{array}$ & $\begin{array}{l}\text { Alongamento } \\
\text { na ruptura / \% }\end{array}$ & $\begin{array}{c}\text { Módulo a } \\
25 \%\end{array}$ \\
\hline $\begin{array}{c}0,5 \text { - } 1163 \text { - Não } \\
\text { irradiado }\end{array}$ & $6 \pm 1,1$ & $306 \pm 1,0$ & 2,2 \\
\hline 0,5 - 1163 - 5kGy & $6 \pm 0,8$ & $308 \pm 1,5$ & 1,9 \\
\hline 0,5 - 1163 - 10kGy & $11 \pm 0,9$ & $174 \pm 1,2$ & 3,7 \\
\hline 0,5 - 1163 - 20kGy & $15 \pm 3,4$ & $78 \pm 4,7$ & 4,5 \\
\hline $\begin{array}{c}1 \text { - } 1163 \text { - Não } \\
\text { irradiado }\end{array}$ & $4,9 \pm 0,6$ & $271 \pm 3,2$ & 2,0 \\
\hline 1 - 1163 - 5kGy & $5,9 \pm 1,2$ & $253 \pm 1,5$ & 2,1 \\
\hline 1 - 1163 - 10kGy & $10,4 \pm 1,1$ & $246 \pm 2,6$ & 2,7 \\
\hline 1 - 1163 - 20kGy & $5,2 \pm 0,6$ & $54 \pm 1,1$ & 2,8 \\
\hline $\begin{array}{c}2 \text { - } 1163 \text { - Não } \\
\text { irradiado }\end{array}$ & $4,3 \pm 0,3$ & $180 \pm 1,6$ & 2,1 \\
\hline 2 - 1163 - 5kGy & $6,7 \pm 1,6$ & $209 \pm 1,0$ & 2,5 \\
\hline 2 - 1163 - 10kGy & $9,6 \pm 1,5$ & $178 \pm 3,1$ & 3,2 \\
\hline 2 - 1163 - 20kGy & $16,5 \pm 0,9$ & $152 \pm 2,7$ & 3,7 \\
\hline
\end{tabular}


Na FIG. 51 estão demonstrados os valores de dureza para os filmes incorporados com argila e vulcanizados após a irradiação. Pela análise dos resultados foi observado o aumento da dureza do material com o aumento da dose e da quantidade de argila incorporada. Este aumento está relacionado com a uniformidade da dispersão das camadas de argila na matriz polimérica, que ocasionou o aumento da interação entre as camadas de argila e a borracha, aumentando a rigidez da cadeia polimérica.

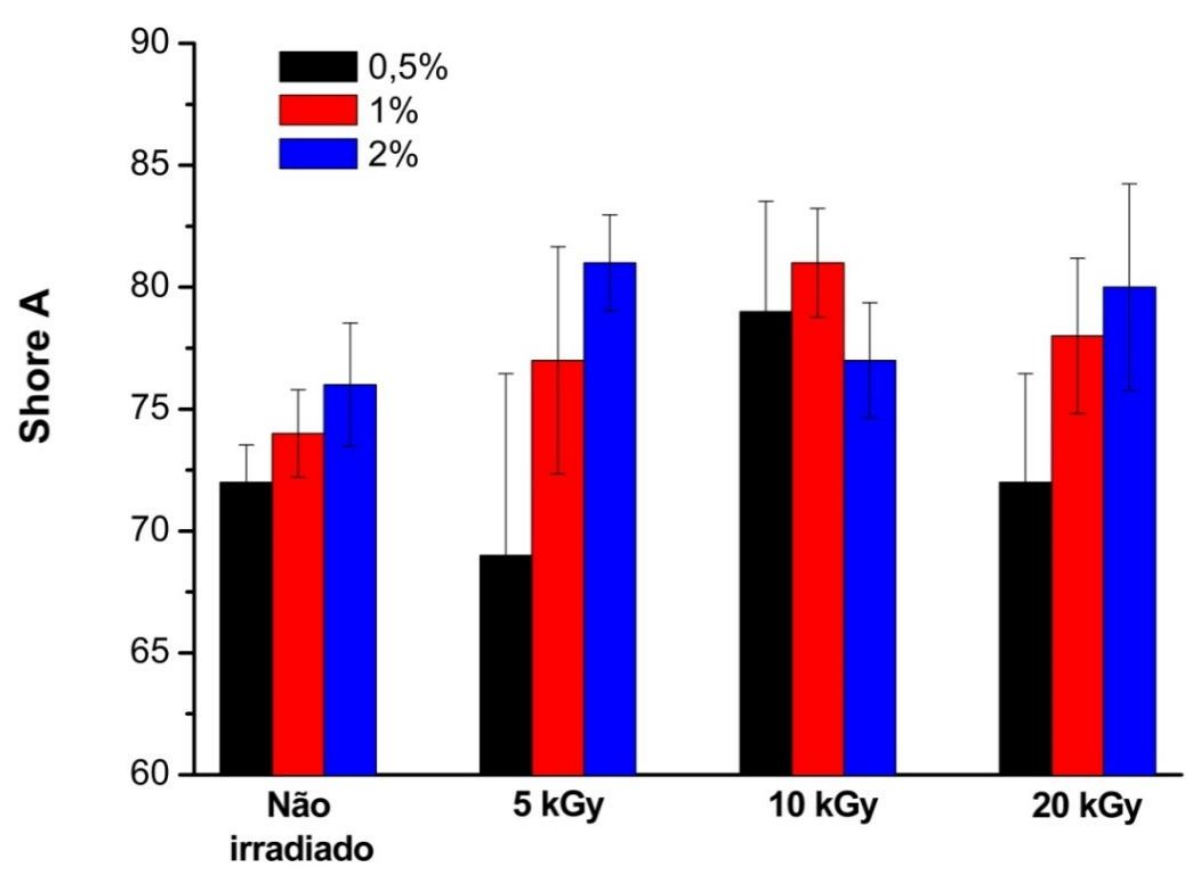

FIGURA 51 - Resultado do ensaio de dureza dos filmes FKM incorporados com argila Cloisite 15A, vulcanizados após a irradiação e da amostra não irradiada.

Nas FIG. 52 a 54 estão representados os valores de dureza obtidos para as amostras incorporadas com POSS. Observou-se que houve uma tendência de aumento da dureza com o aumento da quantidade de nanopartícula incorporada e com a dose irradiada. Este aumento de dureza está relacionado com o aumento de rigidez da cadeia do elastômero ocasionada pela diminuição da mobilidade da cadeia, causada pela estrutura nanométrica tipo gaiola do POSS. 


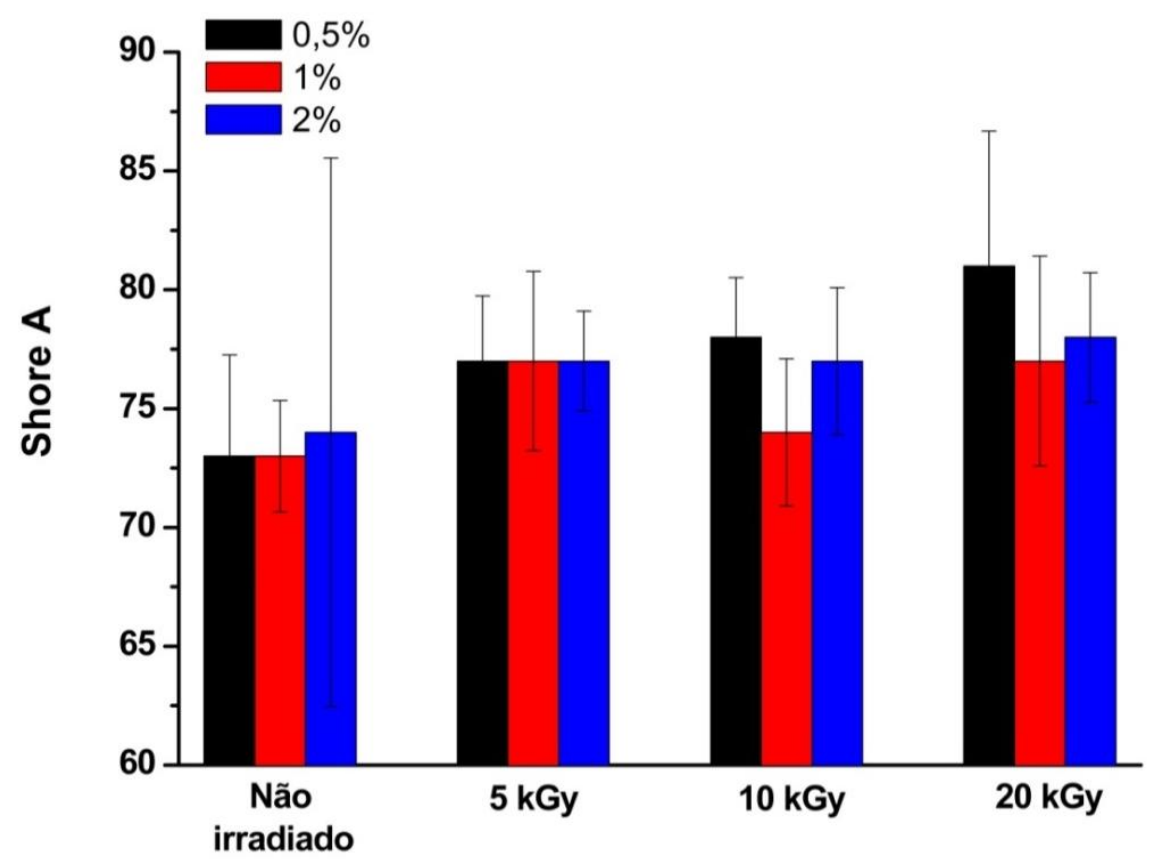

FIGURA 52 - Resultado do ensaio de dureza dos filmes FKM incorporados com POSS 1159 vulcanizados após a irradiação e da amostra não irradiada

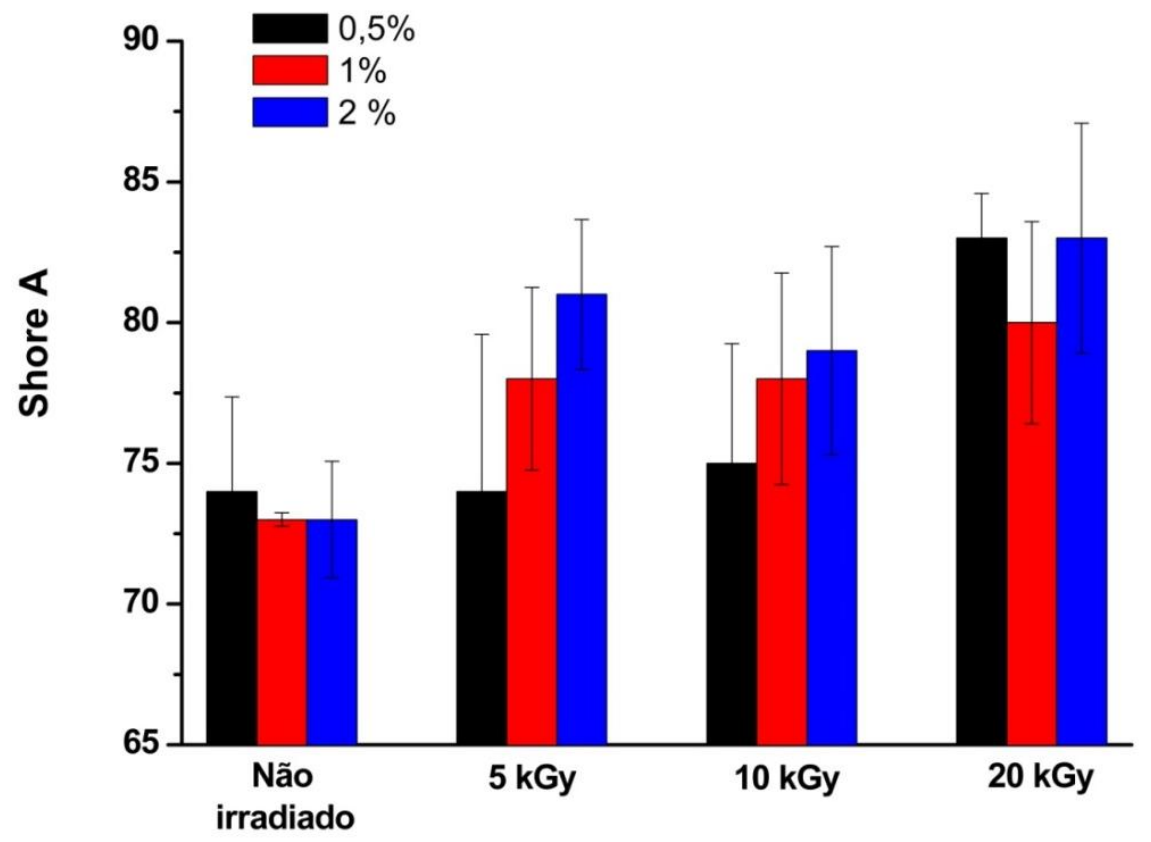

FIGURA 53 - Resultado do ensaio de dureza dos filmes FKM incorporados com POSS 1160 vulcanizados após a irradiação e da amostra não irradiada 


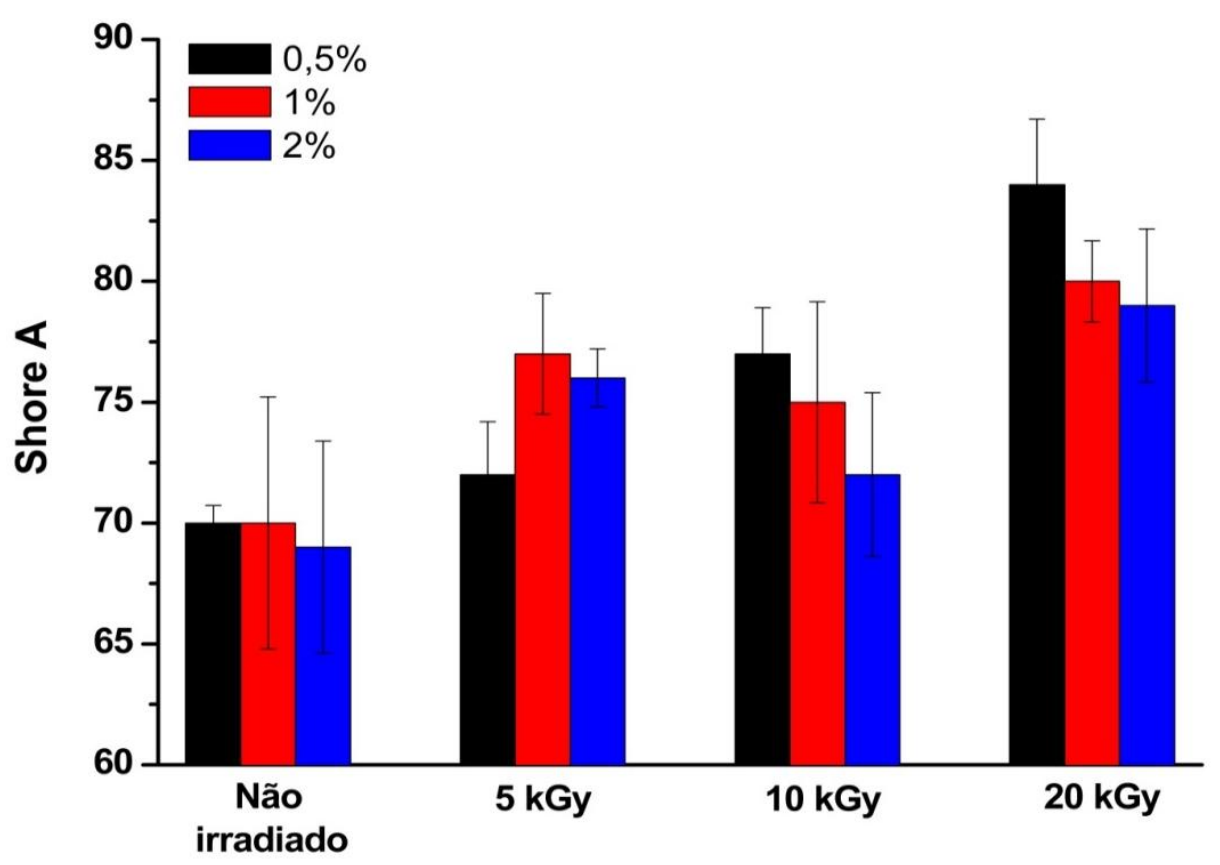

FIGURA 54 - Resultado do ensaio de dureza dos filmes FKM incorporados com POSS 1163 vulcanizados após a irradiação e da amostra não irradiada

O efeito da uniformidade da dispersão e da forte interação argilaborracha também foi confirmado pela redução dos valores de intumescimento em MEK, que estão apresentados nas FIG. 55 a 58. Estes resultados corroboraram o aumento da densidade de reticulação nestes filmes em decorrência do processamento prévio de irradiação, seguido da vulcanização.

Na FIG. 55 estão representados os valores de intumescimento dos filmes incorporados com argila e vulcanizados após a irradiação. Em todos os filmes foi confirmado o aumento na densidade de reticulação pela diminuição de intumescimento destes filmes. 


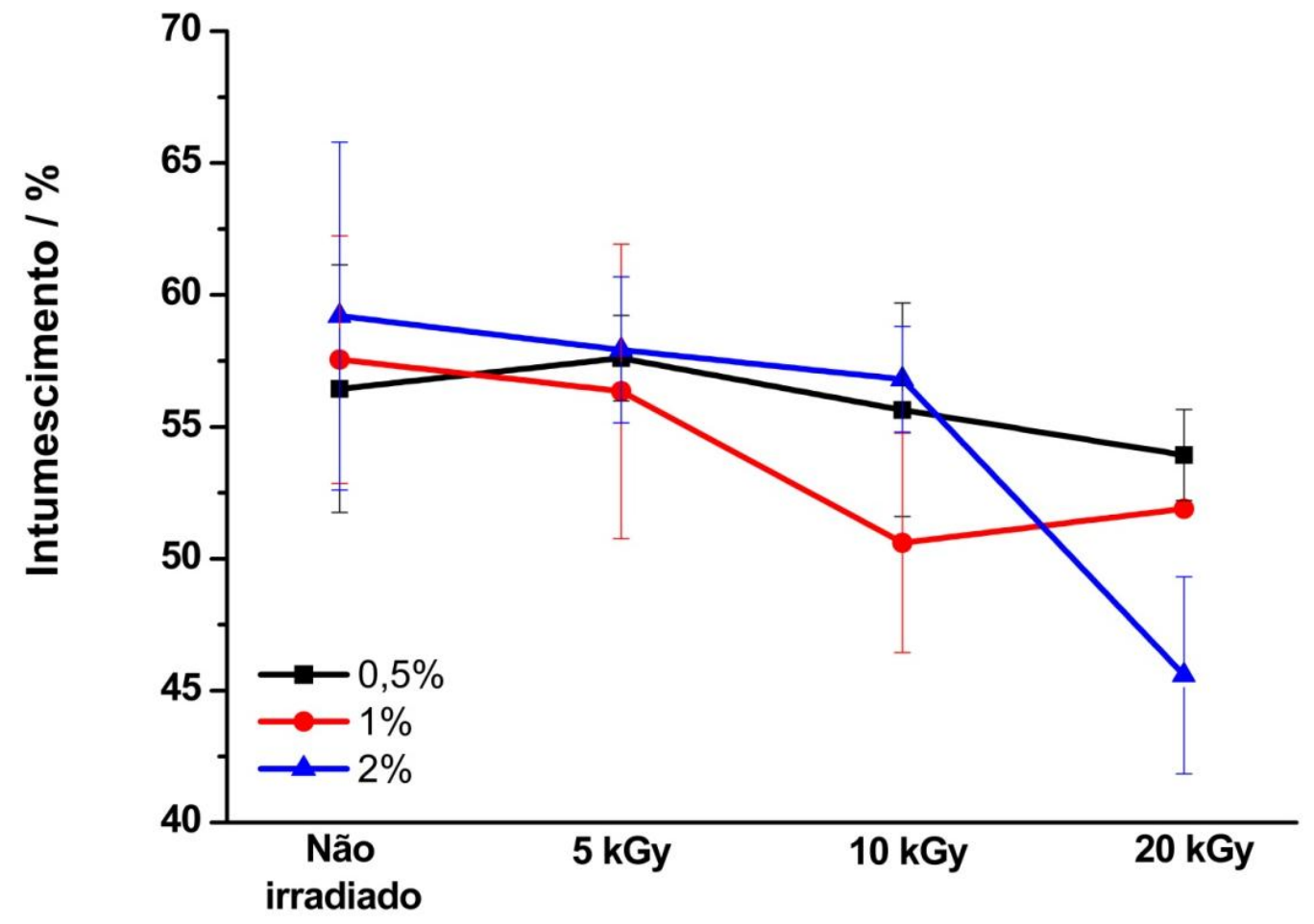

FIGURA 55 - Resultado do teste de intumescimento em MEK dos filmes FKM incorporados com argila Cloisite 15A vulcanizados após a irradiação e do filme não irradiado

$\mathrm{Na}$ Fig. 56 estão demonstrados os resultados obtidos de intumescimento para os filmes incorporados com POSS 1159. Os filmes incorporados com $1 \%$ de nanopartícula e irradiados apresentaram diminuição do intumescimento em relação ao filme não puro, confirmando a predominância da reticulação da matriz polimérica. Porém, os filmes incorporados com $0,5 \%$ apresentaram comportamento variável, sem indicar predominância de um dos efeitos da irradiação.

Os filmes incorporados com $2 \%$ de nanopartícula apresentaram aumento de intumescimento até a dose de 10kGy e a 20kGy houve uma diminuição no intumescimento, confirmando a predominância do efeito da degradação da cadeia polimérica pelo processo de irradiação. Estes valores estão em acordo com os resultados de tensão e alongamento, que também revelaram 
aumento do alongamento até a dose de 10kGy e depois a diminuição quando irradiado a 20kGy.

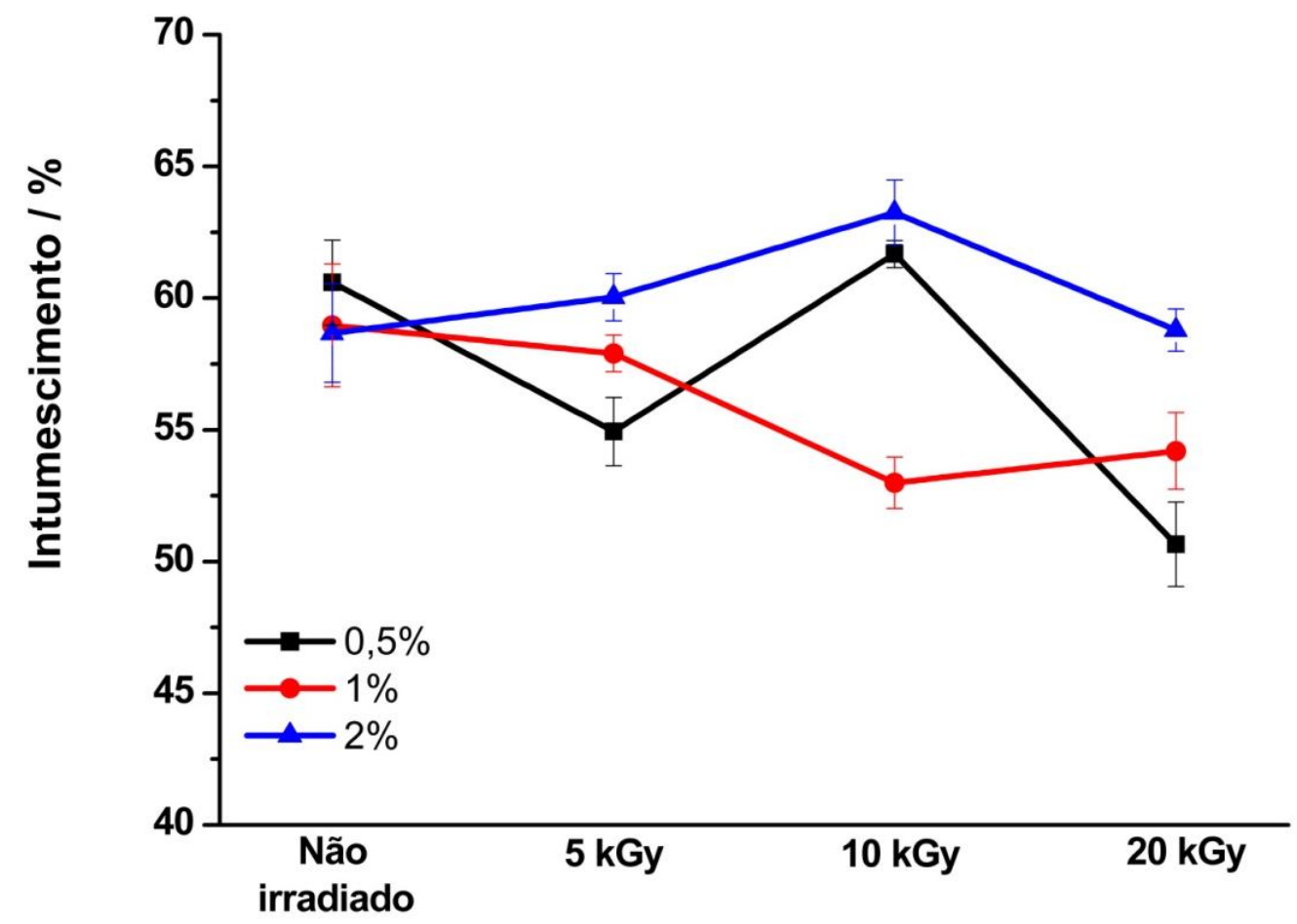

FIGURA 56 - Resultado do teste de intumescimento em MEK dos filmes FKM incorporados com POSS 1159 vulcanizados após a irradiação e do filme não irradiado

Na FIG. 57 estão demonstrados os valores de intumescimento para as amostras incorporadas com POSS 1160. Os filmes incorporados com 0,5 e 1\% tiveram decréscimo dos valores de intumescimento, confirmando os resultados de análise mecânica da predominância da reticulação da cadeia de fluoroelastômero. Entretanto, os filmes incorporados com $2 \%$ tiveram aumento de intumescimento, revelando tendência à degradação do $\mathrm{FKM}$, porém este fato não foi observado pelos resultados de análise mecânica. 


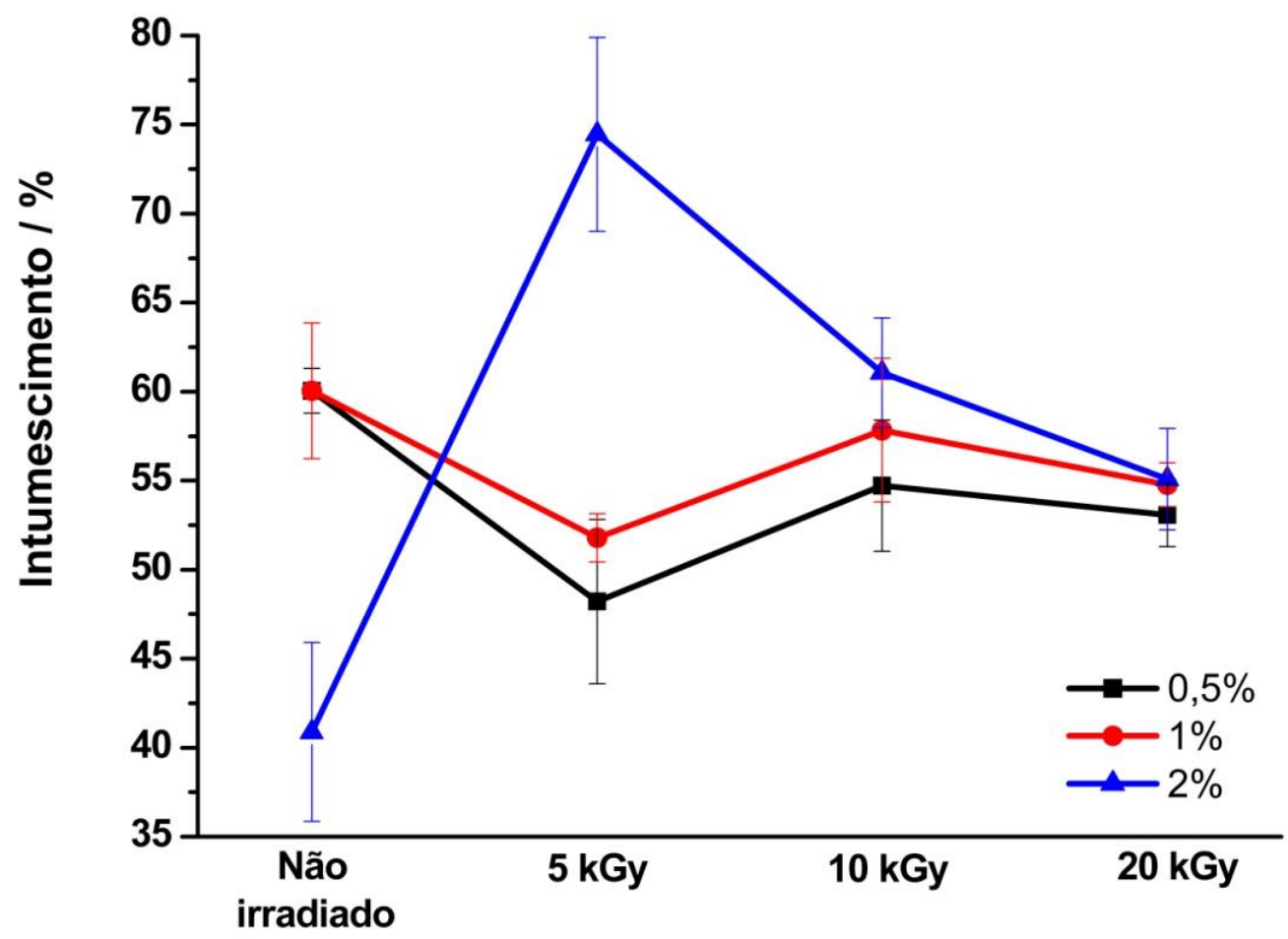

FIGURA 57 - Resultado do teste de intumescimento em MEK dos filmes FKM incorporados com POSS 1160 vulcanizados após a irradiação e do filme não irradiado.

A nanopartícula POSS 1163 foi indicada como agente de reticulação para borracha e conforme demonstrado na FIG. 58, esta aplicação foi confirmada pela diminuição do intumescimento dos filmes incorporados e vulcanizados após a irradiação. 


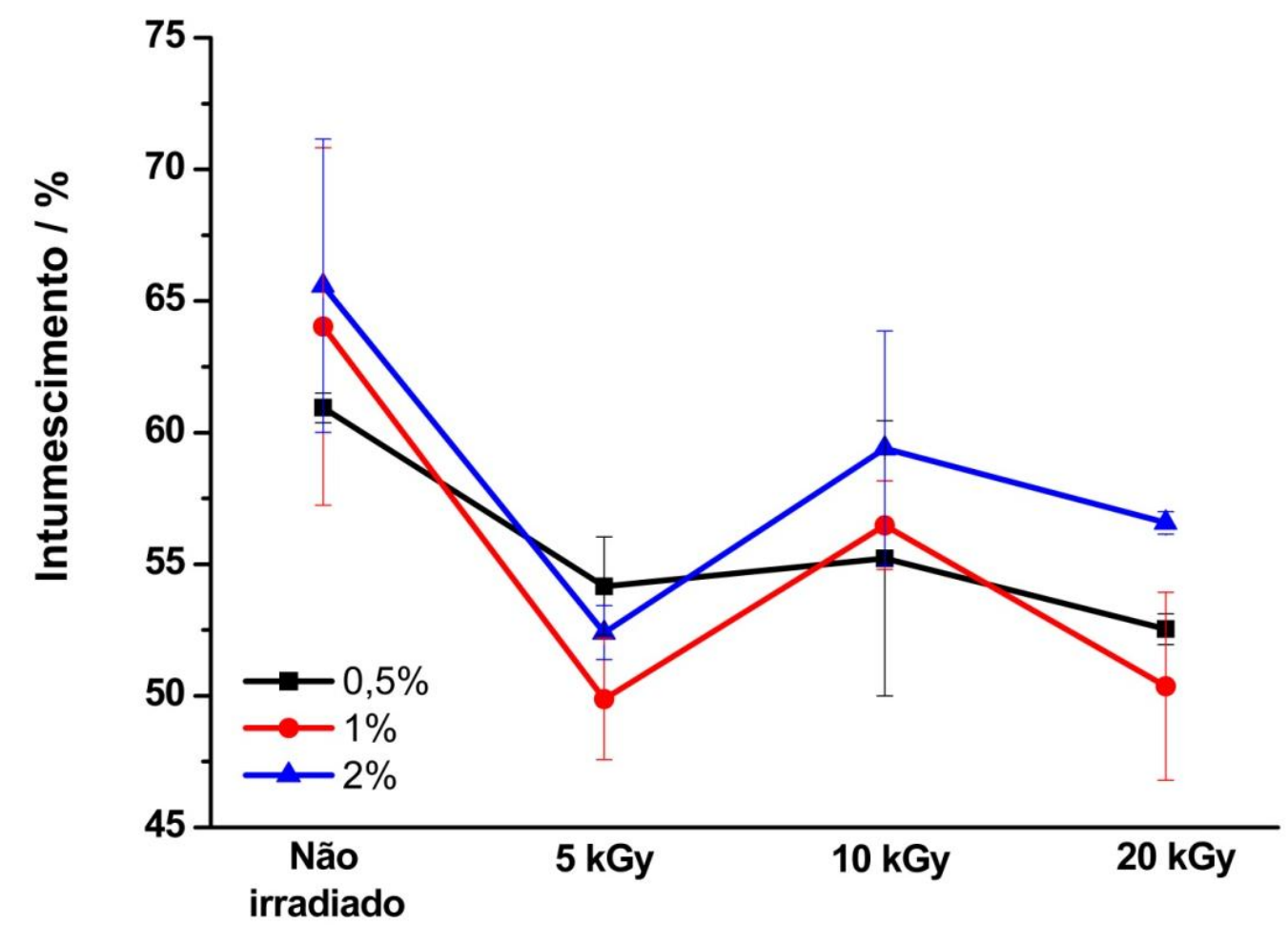

FIGURA 58 - Resultado do teste de intumescimento em MEK dos filmes FKM incorporados com POSS 1163 vulcanizados após a irradiação e do filme não irradiado

\subsection{Enxertia induzida por radiação gama seguida de sulfonação}

Para a reação de enxertia induzida por radiação gama foram realizados diferentes métodos de irradiação, diferentes soluções de enxertia, diferentes temperaturas de reação de enxertia e diferentes doses de irradiação. As doses de irradiação foram determinadas em 5, 10 e 20kGy para diminuir o efeito da degradação por cisão de cadeia e por oxidação causado pela irradiação. Todas as soluções descritas na parte experimental foram testadas nos três métodos de irradiação e em duas condições de temperatura durante a irradiação. Os métodos de irradiação avaliados também foram descritos na parte experimental, no item 4.2.3. 
A obtenção de rendimentos de enxertia em polímeros parcialmente cristalino está relacionada com cristalinidade da cadeia polimérica e também com a estabilidade e acessibilidade dos radicais livres gerados na cadeia polimérica. A irradiação em polímeros fluorados parcialmente cristalino a temperatura ambiente produz radicais tanto na fase cristalina quanto na fase amorfa destes polímeros. Durante o processo de enxertia induzida por radiação ionizante alguns radicais se recombinam ou se transferem; alguns radicais da fase amorfa se recombinam com os radicais gerados no monômero originado os enxertos na cadeia polimérica; e os radicais gerados na fase cristalina são preservados e com o passar do tempo estarão acessíveis na interface com a fase amorfa para que novas reações de enxertia aconteçam [124].

A influência da cristalinidade da cadeia polimérica foi reportada em trabalhos publicados por Tabata et al [69 - 74]. Os pesquisadores irradiaram polímero fluorado semicristalino (PTFE) na temperatura de fusão, $330^{\circ} \mathrm{C}$, para obter o polímero sem a fase cristalina durante a irradiação, o que ocasionou o aumento da mobilidade da cadeia polimérica. Este aumento da mobilidade possibilita a recombinação dos radicais livres entre si, causando a reticulação da cadeia, apesar da temperatura elevada $\left(330^{\circ} \mathrm{C}\right)$ também ter causado alguma cisão de cadeia.

Com relação à estabilidade dos radicais Dargaville [124] irradiou PFA (poli(tetrafluoroetileno-co-perfluoro alquil vinil éter) a temperatura ambiente e verificou que nos primeiros 50 dias após a irradiação, os radicais se decompõem rapidamente até atingir $60 \%$ de sua quantidade original. Este decaimento foi devido às reações de recombinação dos radicais livres que se formaram no final das cadeias. Estes radicais gerados no final das cadeias que recombinaram estavam disponíveis região amorfa ou na interface dos cristais.

As amostras não vulcanizadas irradiadas e não irradiadas não apresentaram rendimentos de enxertia em nenhum sistema estudado e, portanto, não foram submetidas à reação de sulfonação. Este resultado pode ser explicado pela enorme mobilidade das cadeias poliméricas que facilitam a recombinação dos radicais livres gerados e também pela possibilidade do sistema de 
vulcanização (ainda não ligado à cadeia) ter atuado como estabilizante, capturando os radicais e impedindo suas reações.

As amostras vulcanizadas (antes e depois da irradiação) que foram imersas em solução de estireno e tolueno, apresentaram rendimentos abaixo de $2 \%$, o que também não foi suficiente para propiciar a reação de sulfonação. Nesse sistema a presença de mobilidade da cadeia polimérica propiciou o rápido decaimento dos radicais livres, e, além disso, a solução de enxertia estireno/tolueno se mostrou ineficiente para o intumescimento dos filmes e para a penetração do monômero na cadeia polimérica.

Os resultados de grau de enxertia (GE) obtidos para os filmes irradiados a 10 e 20kGy pelo método simultâneo com solução de enxertia 4:1 (estireno não purificado:MEK) sob atmosfera de nitrogênio e temperatura ambiente durante irradiação variaram de 2 a $7 \%$, portanto, essas amostras foram submetidas à reação de sulfonação. Após o tempo decorrido de 3 h de reação de sulfonação dos filmes, foi realizada a titulação ácido-base para determinação da capacidade de troca iônica (IEC). Os filmes que ficaram imersos em ácido sulfúrico e $2 \%$ de clorosulfônico não apresentaram resultados de IEC; e os filmes imersos em 20\% de clorosulfônico apresentaram resultados insatisfatórios, menores que 0,03 meq.g ${ }^{-1}$.

A dificuldade da obtenção da enxertia utilizando estireno não purificado pode ser explicada pela diminuição da mobilidade da cadeia polimérica, que foi causada pela reticulação do elastômero durante o processo de vulcanização. A diminuição da mobilidade está diretamente relacionada com a diminuição das reações de recombinação dos radicais livres gerados durante a irradiação. Além da diminuição da mobilidade, a presença do inibidor do estireno na solução de enxertia atuou como capturador dos radicais livres que foram formados durante a irradiação, dificultando a enxertia do monômero na matriz polimérica.

Os filmes FKM incorporados com nanopartícula foram vulcanizados e imersos na solução de enxertia 4:1 (estireno purificado:MEK). Os filmes foram submetidos à irradiação utilizando o método simultâneo com doses totais de 5, 10 
e 20kGy. O rendimento de enxertia foi calculado e os resultados obtidos para a dose de 5kGy ainda foram insatisfatórios (entre 2 e 7\%). Esse baixo rendimento está relacionado com a menor quantidade de radicais livres gerados durante a irradiação, que é diretamente proporcional à dose irradiada. Este fato foi confirmado pelos resultados obtidos para os filmes irradiados a 10 e $20 \mathrm{kGy}$ que apresentaram rendimentos de enxertia superiores a $10 \%$.

Como os resultados obtidos de rendimento de enxertia foram satisfatórios, os filmes foram acondicionados para a reação de sulfonação e posteriormente submetidos ao teste de intumescimento em água para verificar a hidrofilicidade da membrana. Os resultados obtidos de grau de enxertia, de capacidade de troca iônica e de intumescimento estão descritos na TAB. 19. 
TABELA 19 - Resultados obtidos do cálculo de GE, do IEC e do intumescimento em água dos filmes e membranas.

\begin{tabular}{|c|c|c|c|}
\hline Amostra & GE / \% & IEC / meq.g ${ }^{-1}$ & Intumescimento / \% \\
\hline FKM - 10kGy & 16,2 & 0,53 & $42,1 \pm 1,2$ \\
\hline 0,5-15A - 10kGy & 14,6 & 0,31 & $44,0 \pm 2,5$ \\
\hline 1-15A - 10kGy & 13,6 & 2,68 & $40,6 \pm 1,3$ \\
\hline 2-15A - 10kGy & 16,1 & 0,2 & $33,8 \pm 2,3$ \\
\hline 0,5-1159 - 10kGy & 12,9 & 0,05 & $36,9 \pm 2,8$ \\
\hline 1-1159 - 10kGy & 14,6 & 0,12 & $40,6 \pm 2,6$ \\
\hline 2-1159 - 10kGy & 12,6 & 0,43 & $44,9 \pm 1,6$ \\
\hline 0,5-1160 - 10kGy & 14,9 & 0,43 & $33,9 \pm 3,7$ \\
\hline 1-1160 - 10kGy & 15,4 & 2,12 & $40,5 \pm 1,4$ \\
\hline 2-1160 - 10kGy & 12,4 & 0,001 & $17,0 \pm 2,2$ \\
\hline 0,5-1163 - 10kGy & 13,5 & 0,03 & $46,7 \pm 3,2$ \\
\hline 1-1163 - 10kGy & 14,2 & 0,17 & $38,9 \pm 2,7$ \\
\hline 2-1163 - 10kGy & 13,4 & 1,14 & $37,1 \pm 1,5$ \\
\hline FKM - 20kGy & 18,1 & 0,02 & $22,9 \pm 3,1$ \\
\hline 0,5-15A - 20kGy & 17,5 & 0,008 & $15,3 \pm 3,3$ \\
\hline 1-15A - 20kGy & 16,3 & 0,28 & $40,4 \pm 2,8$ \\
\hline 2-15A - 20kGy & 20,5 & 0,28 & $24,9 \pm 1,9$ \\
\hline 0,5-1159 - 20kGy & 16,4 & 0,02 & $28,9 \pm 2,9$ \\
\hline 1-1159 - 20kGy & 17,2 & 0,21 & $30,5 \pm 1,7$ \\
\hline 2-1159 - 20kGy & 16,2 & 0,24 & $40,7 \pm 0,8$ \\
\hline 0,5-1160 - 20kGy & 16,9 & 0,02 & $22,9 \pm 3,4$ \\
\hline 1-1160 - 20kGy & 17,5 & 0,07 & $39,2 \pm 1,4$ \\
\hline 2-1160 - 20kGy & 16,2 & 0,35 & $32,6 \pm 1,7$ \\
\hline 0,5-1163 - 20kGy & 17,1 & 0,67 & $42,0 \pm 2,3$ \\
\hline 1-1163 - 20kGy & 18,5 & 0,15 & $40,8 \pm 1,6$ \\
\hline 2-1163 - 20kGy & 16,8 & 0,19 & $34,6 \pm 1,5$ \\
\hline
\end{tabular}


Com a utilização do estireno purificado foi possível demonstrar que o inibidor do estireno atuava como capturador de radicais livres, diminuindo o rendimento de enxertia nos filmes desenvolvidos, pois, utilizando-se estireno purificado não houve sua participação na captura dos radicais livres gerados durante a reação e o grau de enxertia obtido foi satisfatório.

Os valores calculados de IEC foram insatisfatórios para a maioria das amostras, sendo que para os filmes FKM incorporados com nanopartícula e irradiados a 20kGy foram menores que os filmes irradiados a 10kGy. Estes baixos valores podem estar relacionados à degradação da cadeia polimérica como efeito direto da irradiação. E também a titulação para essa membrana desenvolvida pode não ser uma técnica confiável, visto que o elastômero possui em sua composição diversos outros cátions (como cálcio e magnésio) que podem ter reagido com alguns grupos $\mathrm{SO}_{3}$ do ácido clorofulfônico causando sua neutralização antes do contato com a solução de cloreto de sódio.

Apesar das membranas apresentarem em sua maioria valores de IEC baixo, todas as membranas desenvolvidas intumesceram em água, confirmando 0 caráter hidrofílico das membranas desenvolvidas. Além do intumescimento em água houve também alteração dimensional destas membranas, pois, para a reação de enxertia os filmes foram cortados em tamanho de $3 \mathrm{~cm} \times 3 \mathrm{~cm}$ e após a sulfonação o tamanho aumentou conforme a dose irradiada: os filmes irradiados a $10 \mathrm{kGy}$ apresentaram em média o tamanho $4,5 \mathrm{~cm} \times 4,5 \mathrm{~cm}$; enquanto que os filmes irradiados a 20kGy apresentaram em média o tamanho $4 \mathrm{~cm} \times 4 \mathrm{~cm}$. Na FIG. 59 estão representadas as imagens de dois filmes que ilustram a variação do tamanho dos filmes em decorrência do intumescimento em água, a imagem à direita é a amostra antes do intumescimento e a imagem à esquerda refere-se à amostra após o intumescimento em água. 

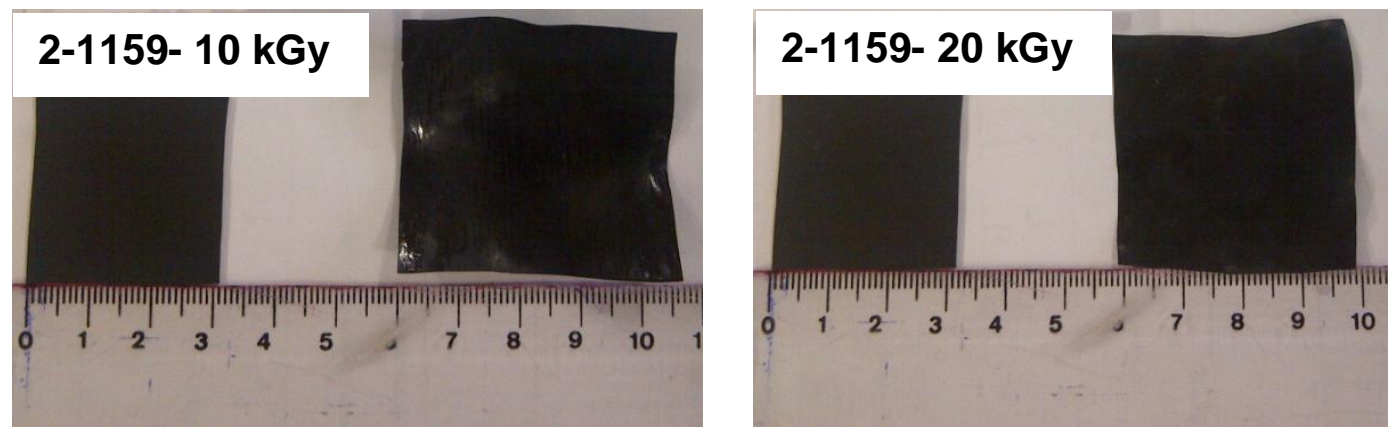

FIGURA 59 - Imagens das membranas após a reação de sulfonação (menor tamanho) e após o intumescimento em água (maior tamanho).

A manipulação das membranas após a reação de sulfonação revelou que as membranas incorporadas com POSS 1163 estavam mais rígidas que as outras membranas. Provavelmente este fato está relacionado com a indicação de uso desta nanopartícula como agente de reticulação para borracha, que aumentou a rigidez do FKM.

Apesar dos filmes terem sido submetidos a baixas doses para evitar a degradação da cadeia polimérica, as reações de enxertia e de sulfonação também contribuíram para aumento da fragilidade e da rigidez das amostras. Portanto, os ensaios para avaliação das propriedades mecânicas não foram realizados nos filmes enxertados e sulfonados. 


\section{CONCLUSÃO}

O processo de mistura em cilindro para a obtenção de nanocompósitos híbridos pelo foi realizada com sucesso. Os nanocompósitos obtidos não continham bolhas ou rachaduras superficiais.

O efeito da degradação como consequência direta do processamento por irradiação foi verificado nas amostras vulcanizadas antes da irradiação. Esta degradação ocorreu tanto por reações de oxidação como por cisão da cadeia polimérica; este efeito foi confirmado pelos resultados obtidos de ensaios mecânico, caracterizado pelo aumento do alongamento e também pelo aumento dos valores de intumescimento; como também pelas imagens de microscopia eletrônica de varredura que ratificaram a degradação superficial dos filmes.

Para amostras vulcanizadas após a irradiação, o efeito predominante foi o da reticulação. A reticulação dos filmes obtidos foi confirmada pelos resultados obtidos de ensaios mecânicos devido ao aumento do módulo e da tensão de ruptura, como também pela diminuição do intumescimento dos filmes.

O processo de enxertia induzida por radiação gama apresentou resultados satisfatórios quando foi utilizado o estireno purificado e em excesso com o MEK para a solução de enxertia. Além da purificação do monômero, os o solvente MEK também contribuiu para a obtenção de enxertos, pois foi 0 responsável pelo intumescimento do filme, facilitando o acesso do estireno aos radicais da cadeia polimérica que possuem rápido decaimento.

O teste de intumescimento em água após a sulfonação confirmou o caráter hidrofílico da membrana e, portanto, a reação de sulfonação foi efetuada com sucesso. Porém, os resultados de capacidade de troca iônica foram insatisfatórios. Sendo assim, novos testes deverão ser efetuados para melhorar a compreensão destes resultados. 
Apêndice A - Resultados de intumescimento em tolueno para os filmes de FKM incorporados com nanopartícula, vulcanizados antes da irradiação e do filme não irradiado.
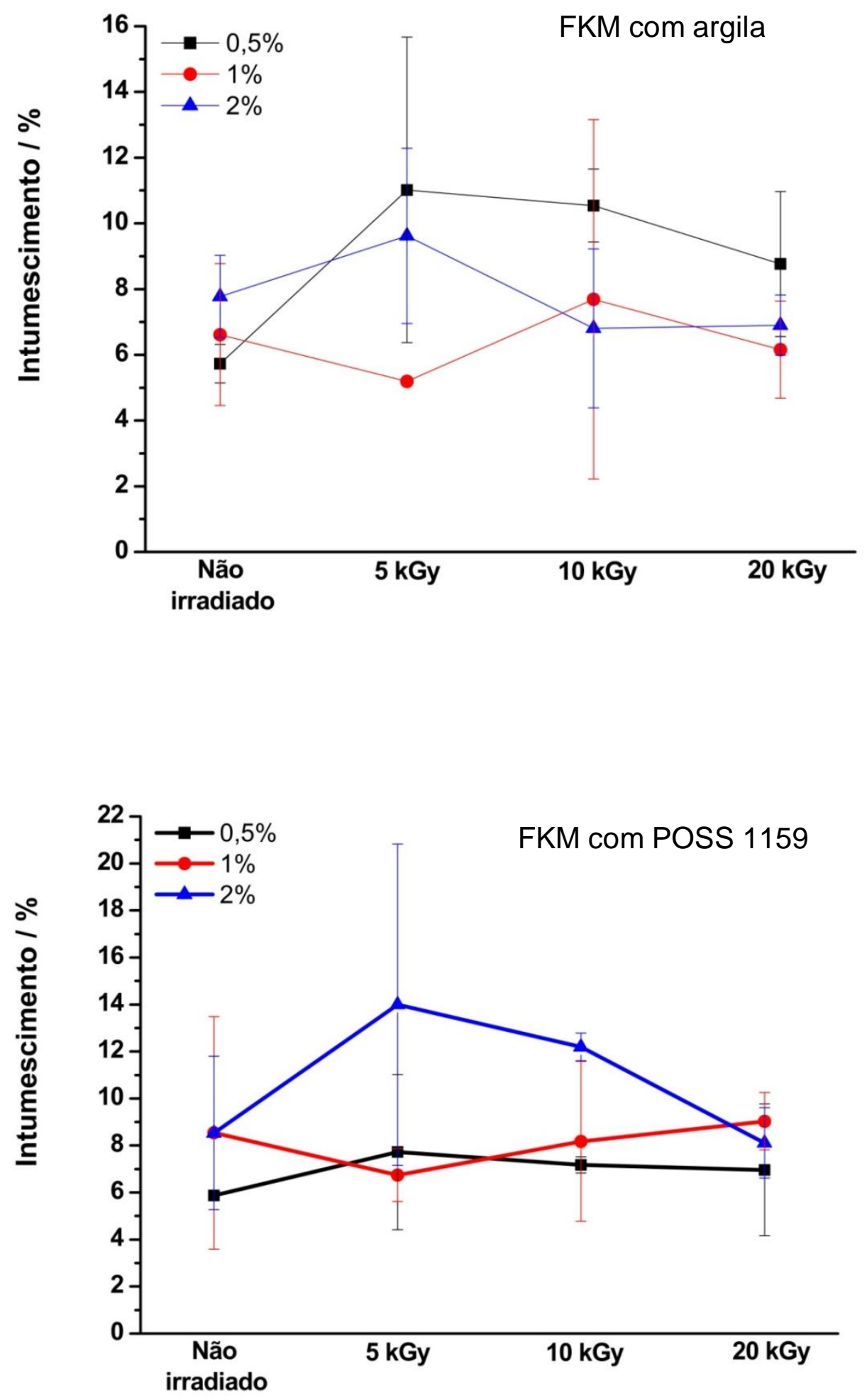

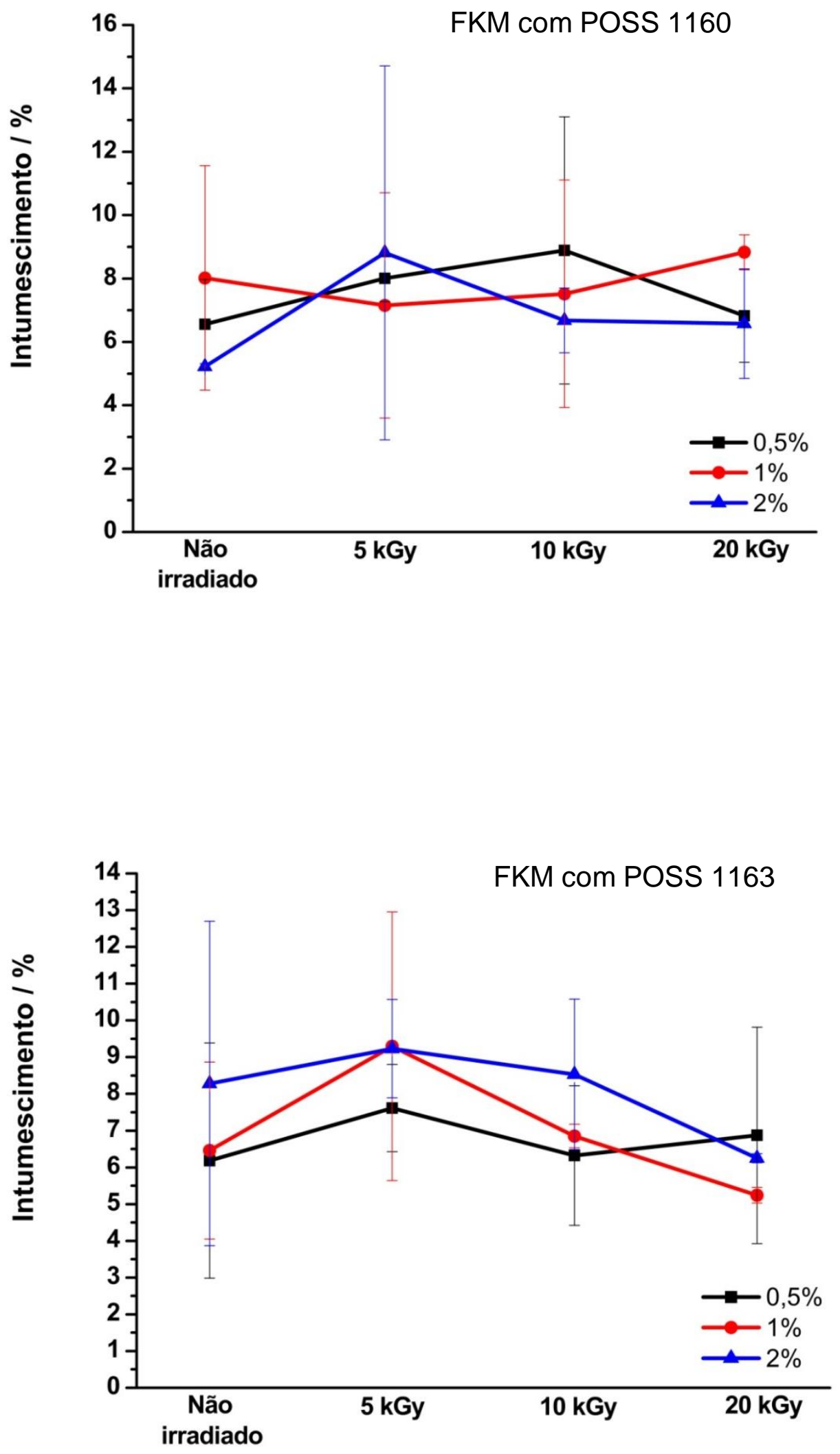
Apêndice B - Resultados de intumescimento em tolueno para os filmes de FKM incorporados com nanopartícula, vulcanizados após a irradiação e do filme não irradiado.
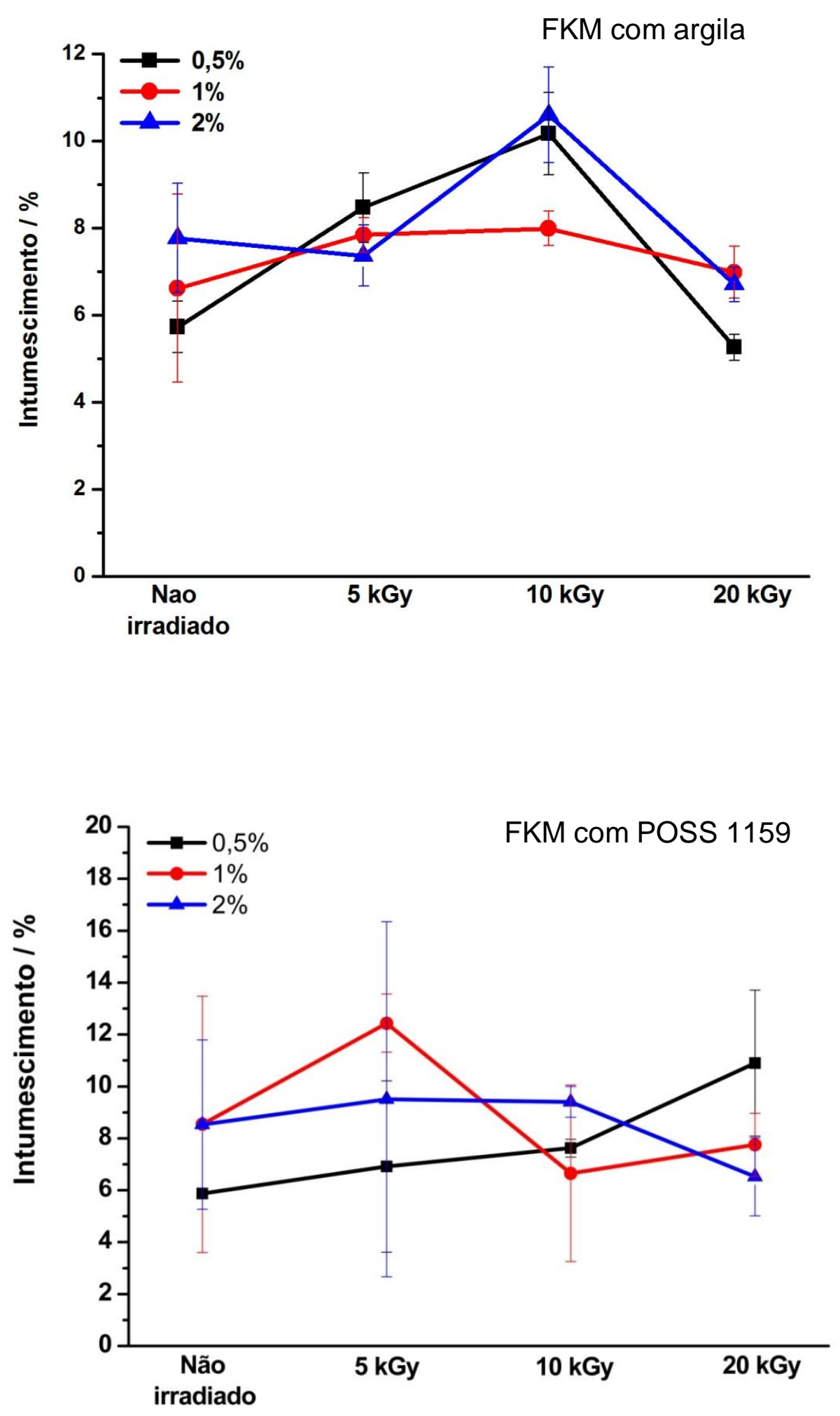

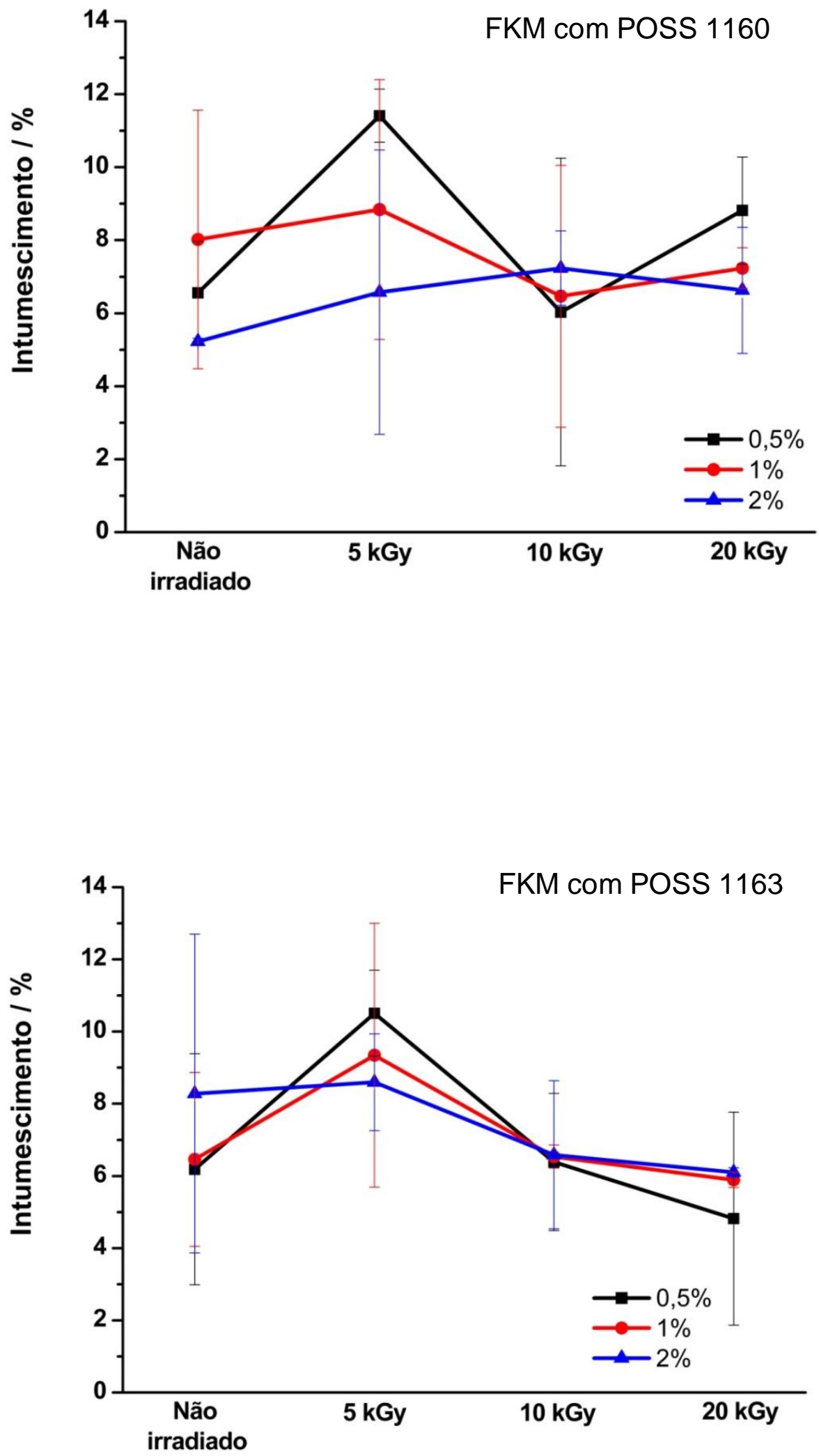


\section{APÊNDICE C - Curvas de tensão $x$ deformação para os filmes incorporados com nanopartícula, vulcanizados antes da irradiação e do filme não irradiado.}
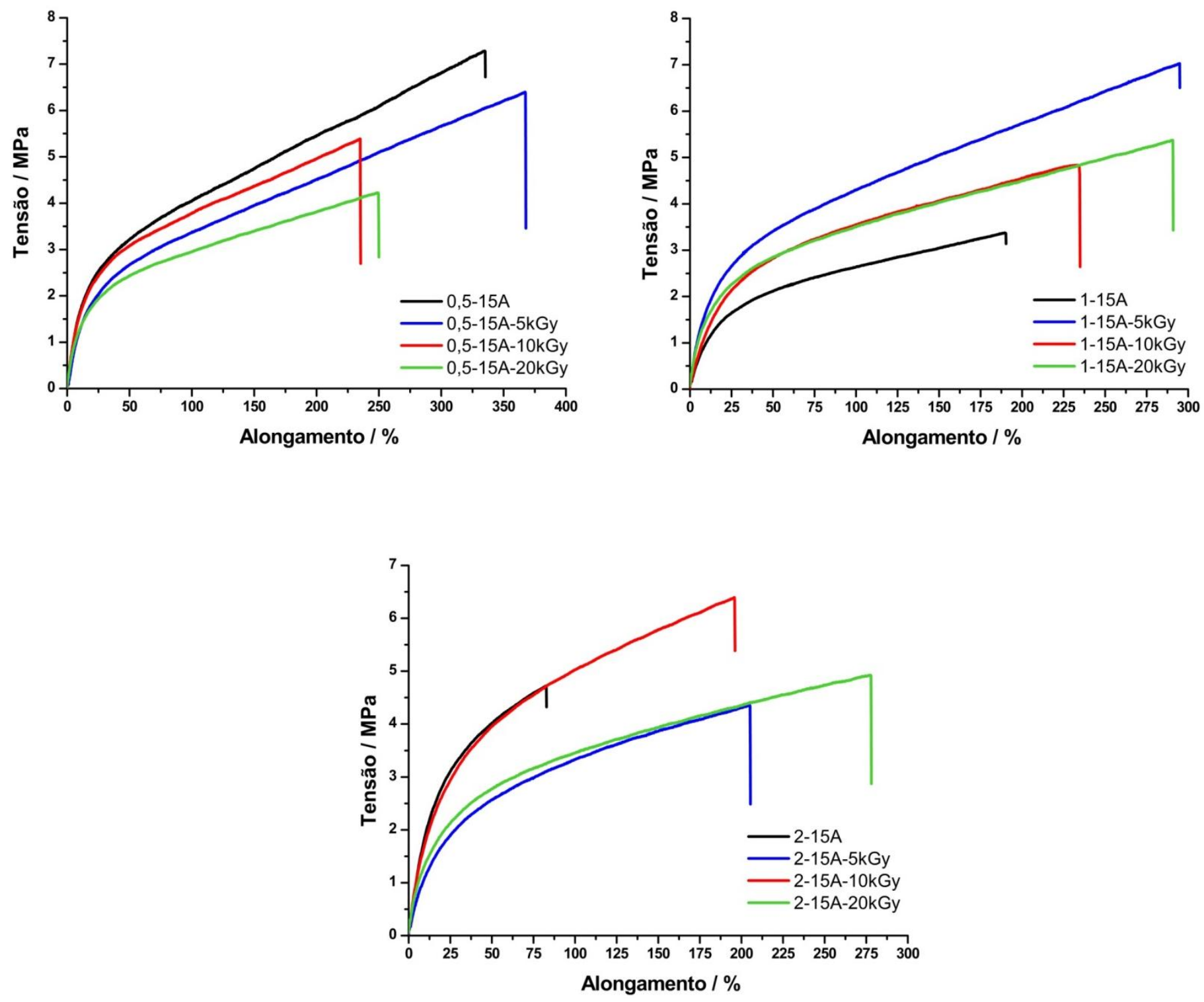

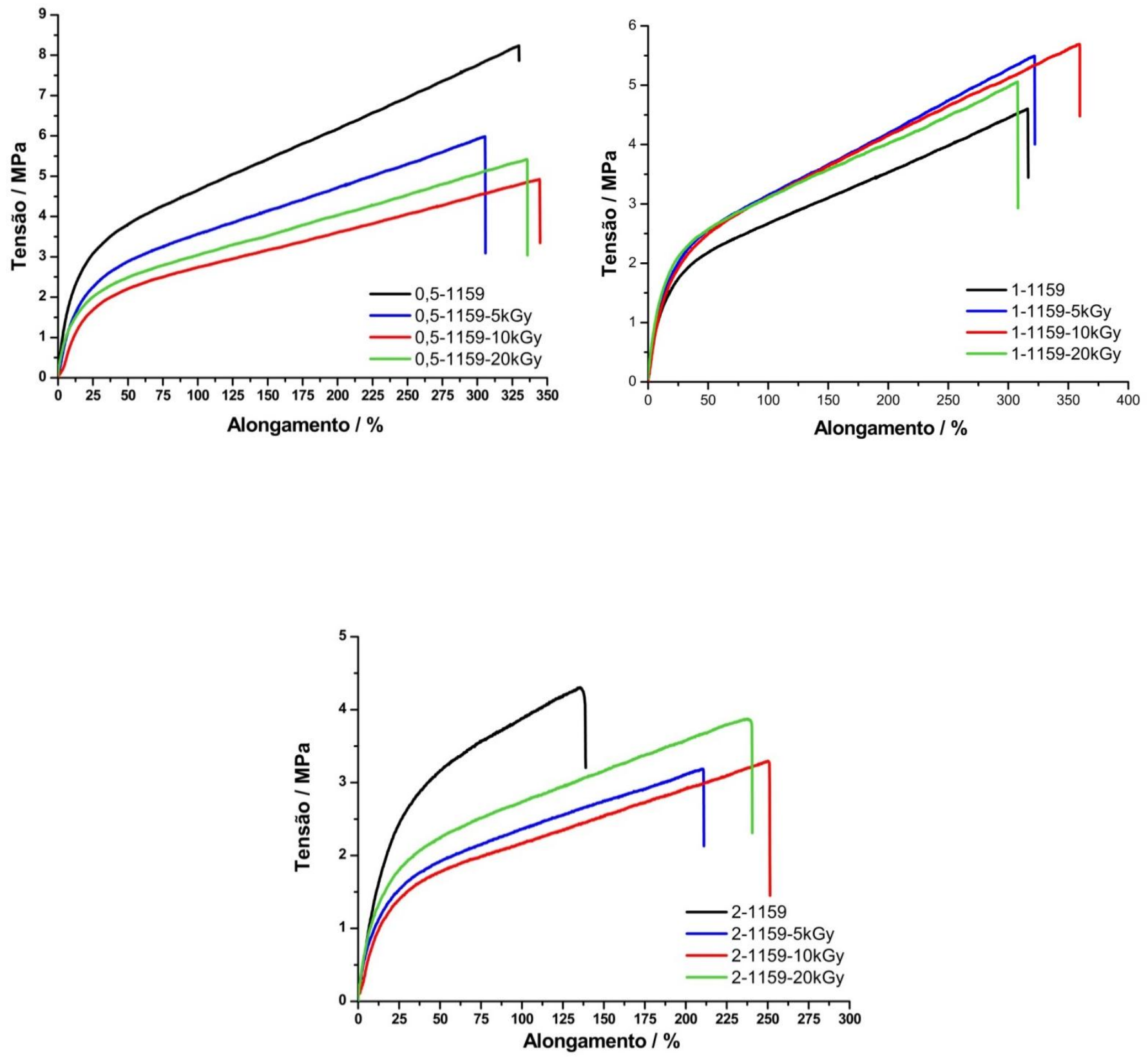

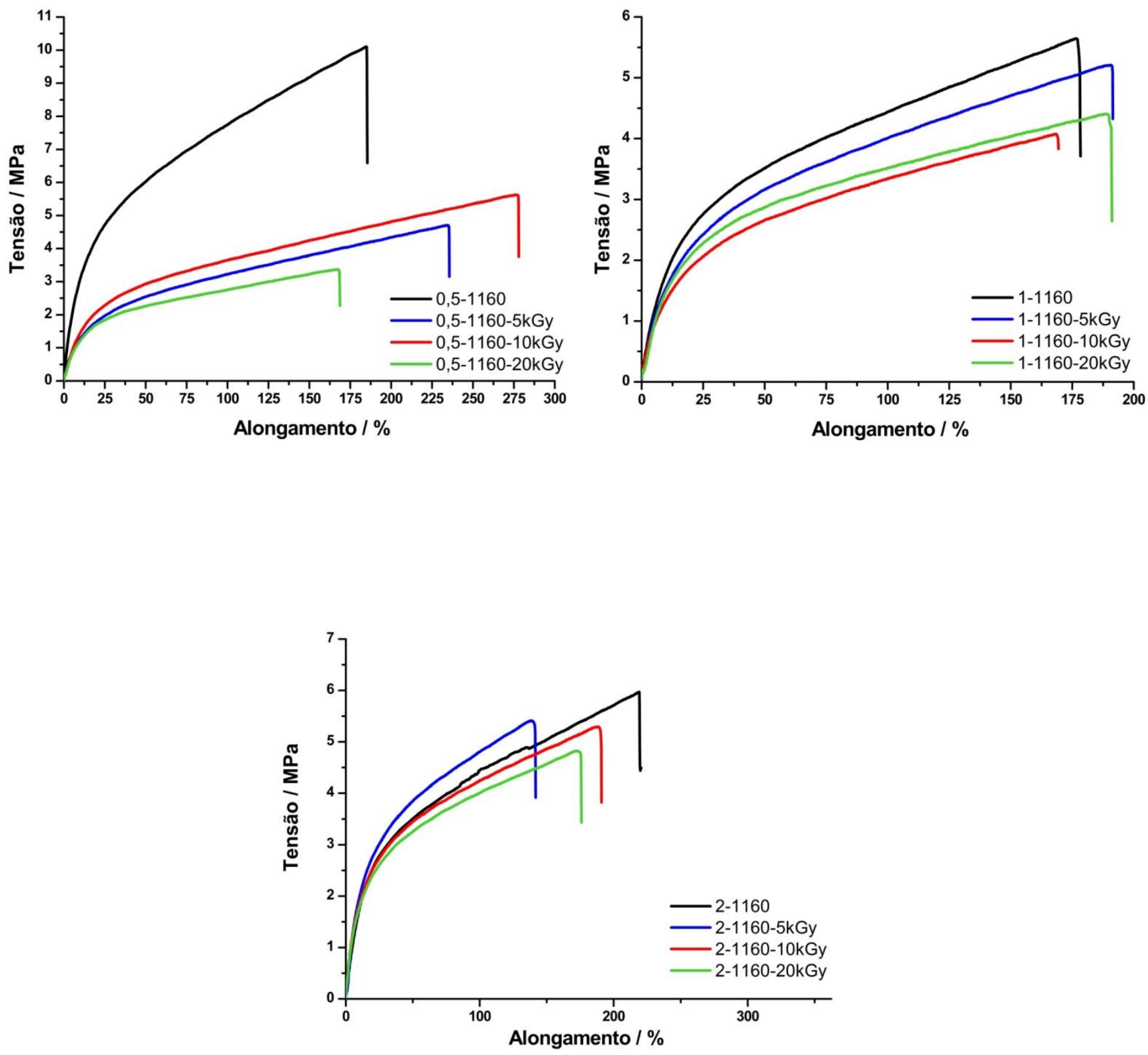

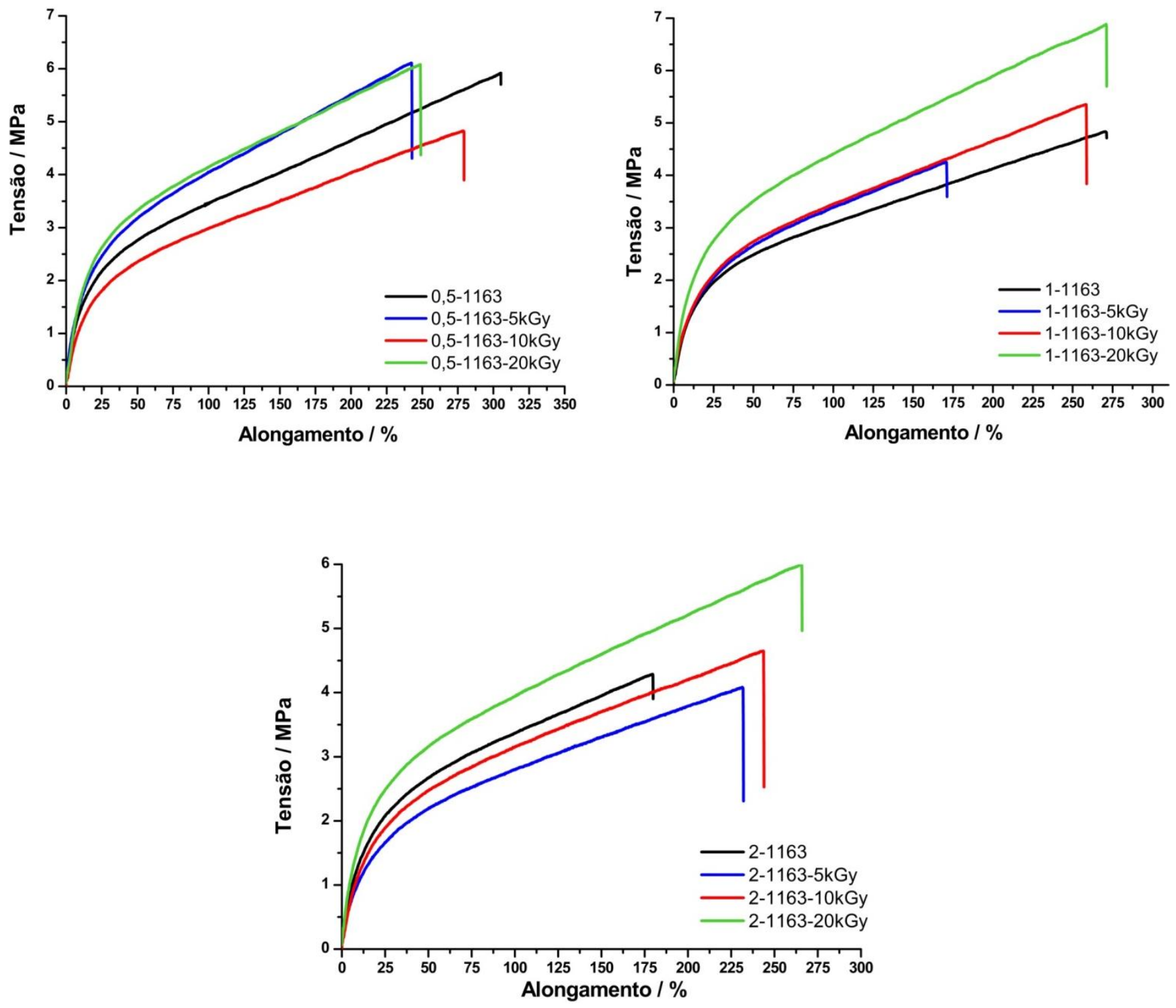


\section{APÊNDICE D - Curvas de tensão $x$ deformação para os filmes incorporados com nanopartícula, vulcanizados após a irradiação e do filme não irradiado.}
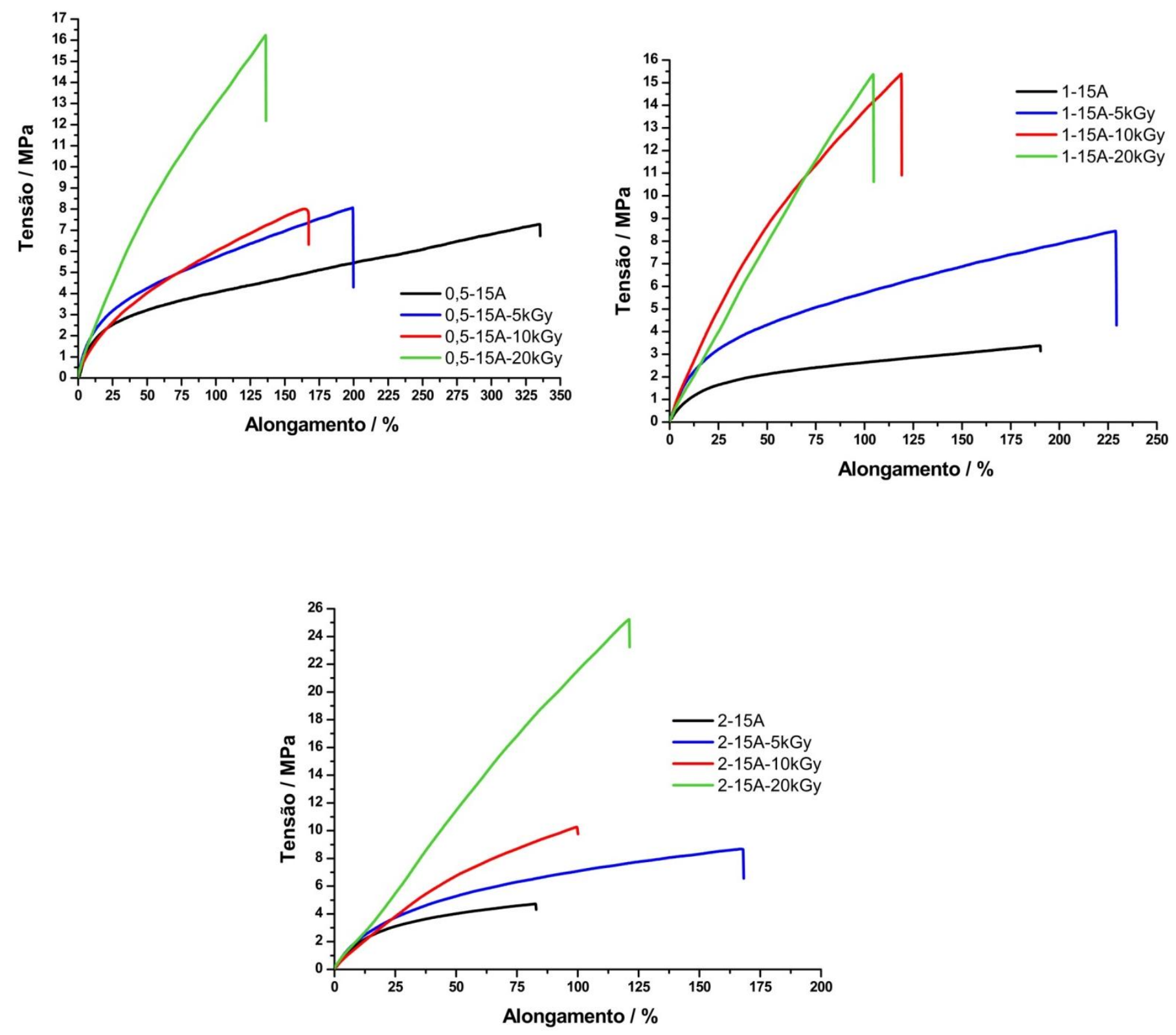

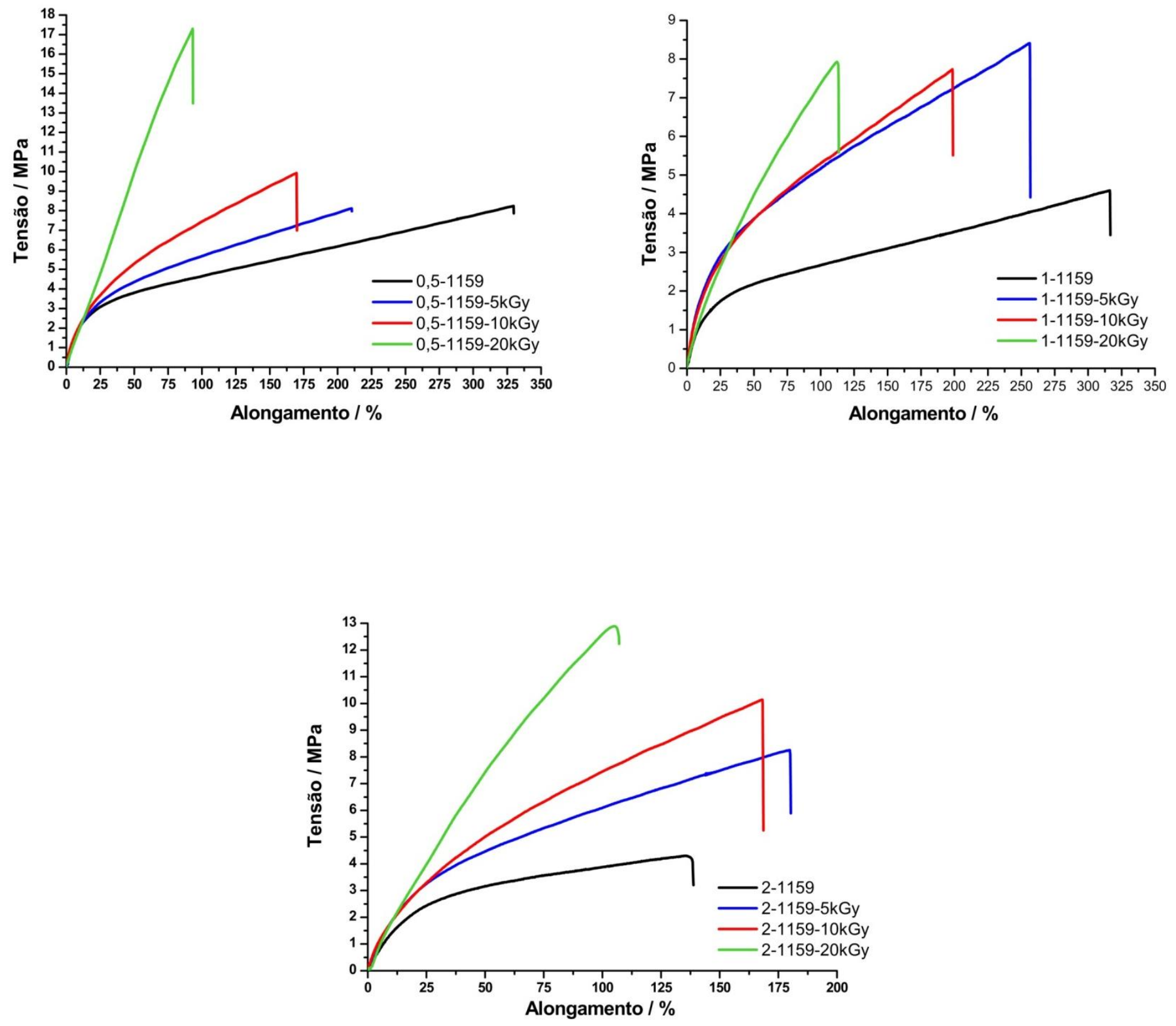

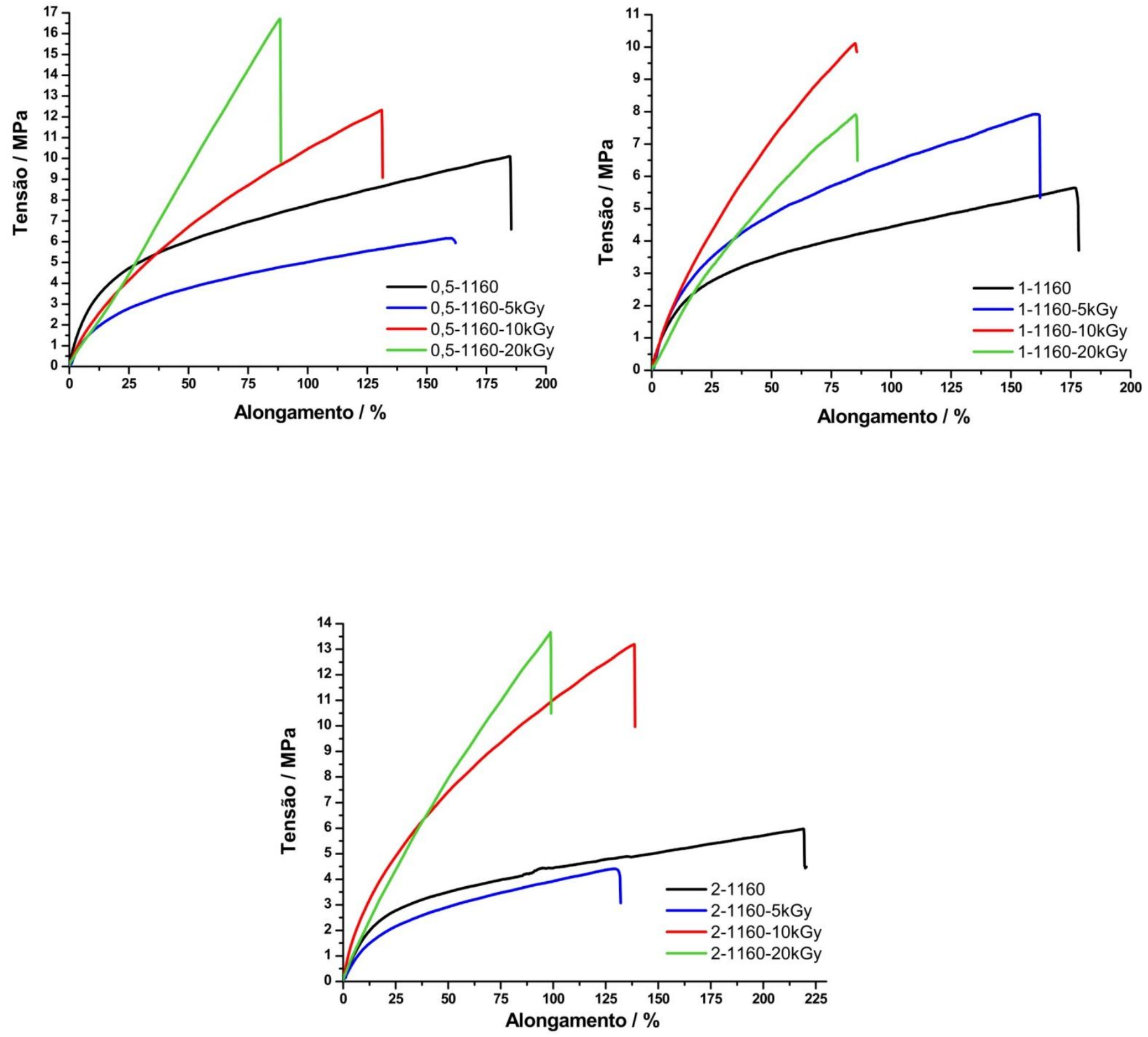

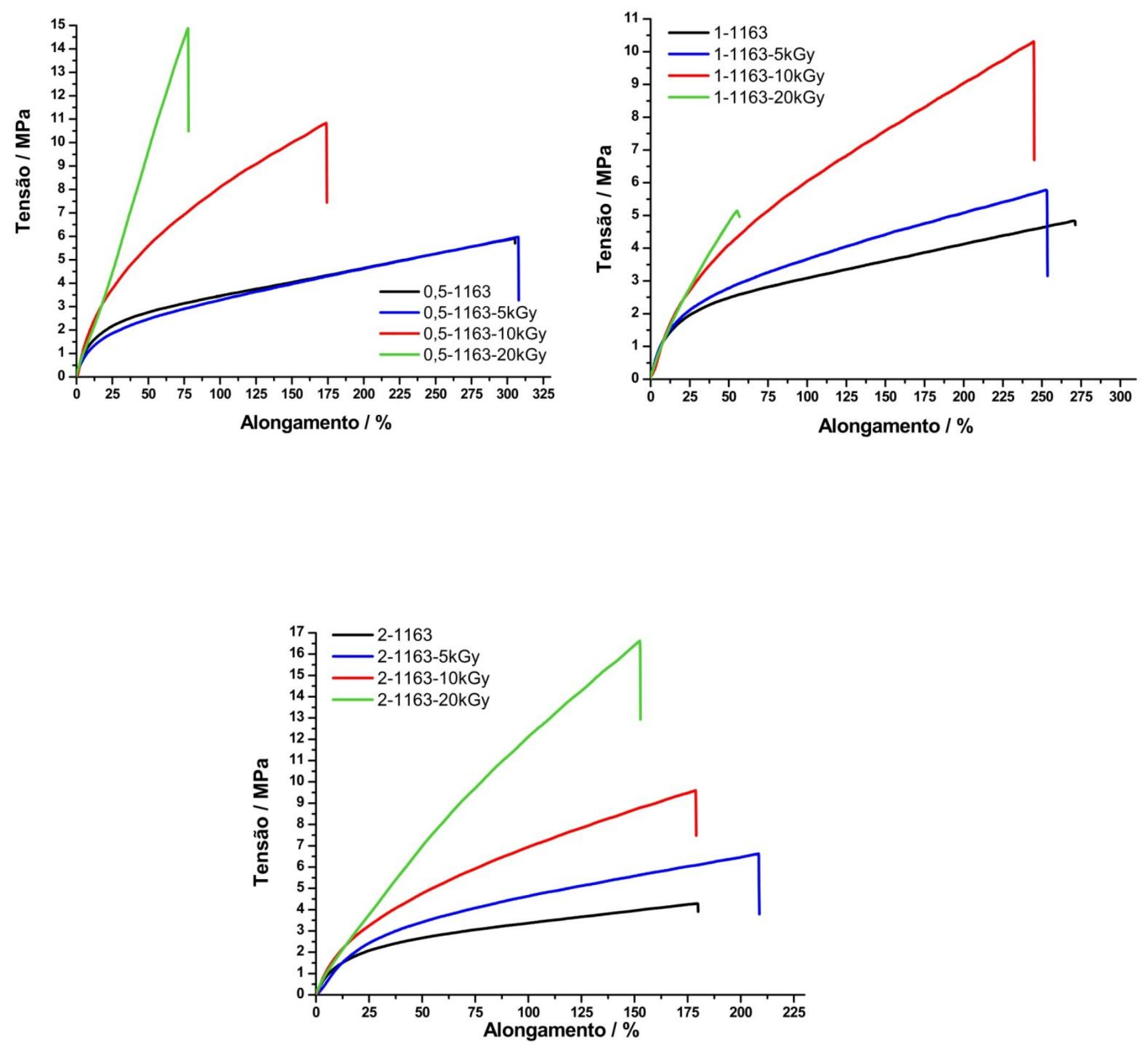


\section{REFERÊNCIAS BIBLIOGRÁFICAS}

1. FRANTA, I. Elastomers and rubbers compounding materials, Amsterdam, 1989, cap. 4. Ed. Elsevier.

2. SINHA N.K. e RAJ, B., PFBR backup seal development. Nucl. Eng. Int., p. 36-38. 2011.

3. SINHA, N.K. e RAJ, B.,. Optimization of material and production to develop fluoroelastômero inflatable seals for sodium cooled fast breeder reactor. Nucl. Eng. Des. v. 241 (3), p. 739-751. 2011.

4. SINHA N.K.; RAJ B.; Mukhopadhyay R., Development of fluoroelastômero backup seal: snapshots of a novel effort in rubber engineering for a critical application (Part I), Sealing Technol., p. 10-13, 2011.

5. SINHA, N.K., RAJ, B., MUKHOPADHYAY, R., Development of fluoroelastômero backup seal: snapshots of a novel effort in rubber engineering for a critical application (Part II). Sealing Technol., p. 9-12. 2011.

6. SINHA, N.K. e RAJ, B., Unification of reactor elastomeric sealing based on material, Nucl. Eng. Des. v. 243, p. 404- 418, 2012.

7. CADAMBI R. M. e GHASSEMIEH E. Hard coatings on elastomers for reduced permeability and increased wear resistance Plast., Rubber Compos. v. 41 (4/5), p. 169-174, 2012.

8. WEI J.; JACOB S.; QIU J., Graphene oxide-integrated high-temperature durable fluoroelastômero for petroleum oil sealing Compos. Sci. Technol., v. 92 , p. 126-133, 2014. 
9. BOUZEK K.; MORAVCOVA S.; SCHAUER J.; BROZ`OVA' L.; PIENTKA Z., Heterogeneous ion-selective membranes: the influence of the inert matrix polymer on the membrane properties, J. Appl Electrochem., v. 40, p. 10051018, 2010.

10. LI G.; TAN J.; GONG J.; Degradation of the elastomeric gasket material in a simulated and four accelerated proton exchange membrane fuel cell environments, J. Power Sources v. 205, p. 244- 251, 2012.

11. LIU Y. e WILSON C. W., Investigation into the Impact of n-Decane, Decalin, and Isoparaffinic Solvent on Elastomeric Sealing Materials, Adv. Mech. Eng., 2012.

12. KUNDERA C. e BOCHNIA J. Investigating the stress relaxation of photopolymer O-ring seal models Rapid Prototyping Journal v.20, p. 533540, 2014.

13. VALSECCHI R.; VIGANÒ M.; LEVI M.; TURRI S.; Dynamic mechanical and rheological behavior of fluoroelastomer-organoclay nanocomposites obtained from different preparation methods, J. Appl. Polym. Sci., v. 102, p. 4484 4487, 2006.

14. RIGHETTI M. C.; AJROLDI G.; VITALI M.; PEZZIN G.; Influence of solvent and filler on some physical properties of a fluoroelastomer, J. Appl. Polym. Sci., v. 73, p. 377-384, 1999.

15. MAITI M. e BHOWMICK A. K., Dynamic viscoelastic properties of fluoroelastomer/clay nanocomposites, Polym. Eng. Sci., v. 47 (11), p. 17771787, 2007. 
16. MAITI M. e BHOWMICK A. K.,Effect of polymer-clay interaction on solvent transport behavior of fluoroelastomer-clay nanocomposites and prediction of aspect ratio of nanoclay, J. Appl. Polym. Sci., v. 105, p. 435 - 445, 2007.

17. KADER M. A. e BHOWMICK A. K., Rheological and viscoelastic properties of multiphase acrylic rubber/fiuoroelastomer/poiyacrylate biends, Polym. Eng. Sci., v. 43 (4), p. 975-9862003.

18. MAITI M.; MITRA S.; BHOWMICK A. K., Effect of nanoclays on high and low temperature degradation of fluoroelastomers, Polym. Degrad. Stab., v. 93, p. $188-200,2008$.

19. ZHANG M.; LIN B.; SUNDARARAJ U., Effects of processing sequence on clay dispersion, phase morphology, and thermal and rheological behaviors of PA6-HDPE-clay nanocomposites, J. Appl. Polym. Sci., v. 125, p. E714 E724, 2012.

20. LAKSHMINARAYANAN S.; LIN B.; GELVES G. A.; SUNDARARAJ U., Effect of clay surfactant type and clay content on the rheology and morphology of uncured fluoroelastomer/clay nanocomposites prepared by melt-mixing, $J$. Appl. Polym. Sci., v. 112, p, 3597 - 3604, 2009.

21. ZHANG M. e SUNDARARAJ U., Thermal, rheological, and mechanical behaviors of LLDPE/PEMA/clay nanocomposites: effect of interaction between polymer, compatibilizer, and nanofiller, Macromol. Mater. Eng., v. 291, p. $697-706,2006$.

22. LAKSHMINARAYANAN S.; LIN B.; GELVES G. A., SUNDARARAJ U., Effect of clay surfactant type and clay content on the rheology and morphology of uncured fluoroelastomer/clay nanocomposites prepared by melt-mixing, $\boldsymbol{J}$. Appl. Polym. Sci., v. 112, p. 3597-3604, 2009. 
23. LAKSHMINARAYANAN S., GELVES G. A., SUNDARARAJ U., Vulcanization behavior and mechanical properties of organoclay fluoroelastomer nanocomposites, J. Appl. Polym. Sci., v. 124, p. 5056-5063, 2012.

24. LAKSHMINARAYANAN S.; LIN B.; GELVES G. A.; SUNDARARAJ U., Effect of clay surfactant type and clay content on the rheology and morphology of uncured fluoroelastomer/clay nanocomposites prepared by melt-mixing, $\boldsymbol{J}$. Appli. Polym. Sci., v. 112 (6), p. 3597-3604, 2009.

25. Hybrid Plastics. Disponível em http://www.hybridplastics.com/docs/userv2.06.pdf. Acessado em 09 de fev. de 2010

26. HADDAD T. S. e LICHTENHAN J. D., Hybrid Organic-Inorganic Thermoplastics: Styryl-Based Polyhedral Oligomeric Silsesquioxane Polymers, Macromolecules, v. 29, p. 7302-7304, 1996.

27. NANDA A. K.; WICKS D. A.; MADBOULY S. A.; OTAIGBE J. U., Nanostructured Polyurethane/POSS Hybrid Aqueous Dispersions Prepared by Homogeneous Solution Polymerization, Macromolecules, v. 39, p. 70377043, 2006.

28. CHOI J. H., JUNG C. H., KIM D. K., GANESAN R., Radiation-induced grafting of inorganic particles onto polymer backbone: A new method to design polymer-based nanocompósito, Nucl. Instrum. Methods Phys. Res. B, v. 266, p. 203-206, 2008.

29. FINA A.; TABUANI D.; PEIJS T.; CAMINO G., POSS grafting on PPgMA by one-step reactive blending, Polymer, v. 50, p. 218-226, 2009. 
30. LEWICKI J. P.; PATEL M.; MORRELL P., LIGGAT J.; MURPHY J.; PETHRICK R., The stability of polysiloxanes incorporating nano-scale physical property modifiers, Sci. technol. Adv. Mater., v. 9, p. 024403 (8pp), 2008.

31. PAN G.; MARK J. E.; SCHAEFER D. W., Synthesis and Characterization of Fillers of Controlled Structure Based on Polyhedral Oligomeric Silsesquioxane Cages and Their Use in Reinforcing Siloxane Elastomers, J. Appl. Polym. Sci. Part B: Polym. Phys., v. 41, p. 3314-3323, 2003.

32. LIU Y. R.; HUANG Y. D.; LIU L., Thermal stability of POSS/methylsilicone nanocomposites, Compos. Sci. Technol., v. 67, p. 2864-2876, 2007.

33. JIAO J.; WANG L.; PANPAN L. V.; CUI Y.; MIAO J., Improved dielectric and mechanical properties of silica/epoxy resin nanocomposites prepared with a novel organic-inorganic hybrid mesoporous silica: POSS-MPS, Mater. Lett., v. 129, p. 16-19, 2014.

34. YANG B., XU H., WANG J., GANG S., LI C., Preparation and thermal property of hybrid nanocomposites by free radical copolymerization of styrene with octavinyl polyhedral oligomeric silsesquioxane, J. Appl. Polym. Sci., v. 106, p. $320-326,2007$.

35. CHEN G. X. e SHIMIZU H., Multiwalled carbon nanotubes grafted with polyhedral oligomeric silsesquioxane and its dispersion in poly(L-lactide) matrix, Polymer, v. 49, p. $943-951,2008$. 
36. HAYAKAWA T.; SEINO M.; GOSEKI R.; HIRAI T.; KIKUCHI R.; KAKIMOTO M.; TOKITA M.; YOKOYAMA H.; HORIUCHI S., Fabrication of hierarchically ordered hybrid structures over multiple length scales via direct etching of selforganized polyhedral oligomeric silsesquioxane (POSS) functionalized block copolymer films, Polym. J., v. 38, p. 567-576, 2006.

37. MÄNNLE F.; TOFTEBERG T. R.; SKAUGEN M.; BU H., PETERS T.; DIETZEL P. D. C.; PILZ M., Polymer nanocomposite coatings based on polyhedral oligosilsesquioxanes: route for industrial manufacturing and barrier properties, J. Nanopart. Res., v. 13, p. 4691 - 4701, 2011.

38. XIAO F.; SUN Y.; XIU Y.; WONG C. P., Preparation, thermal and mechanical properties of POSS epoxy hybrid composites, J. Appl. Polym. Sci., v. 104, p. 2113-2121, 2007.

39. WADDON A. J. e COUGHLIN E. B., Crystal structure of polyhedral oligomeric silsequioxane (POSS) nano-materials: a study by x-ray diffraction and electron microscopy, Chem. Mater., v. 15 (24), 2003.

40. WADDON A. J.; ZHENG L.; FARRIS R. J.; COUGHLIN E. B., Nanostructured polyethylene-POSS copolymers: control of crystallization and aggregation, Nanoletters, v. 2 (10), p. 1149-1155, 2002.

41. ZHENG L.; WADDON A. J.; FARRIS R. J.; COUGHLIN E. B., X-ray characterizations of polyethylene polyhedral oligomeric silsesquioxane copolymers, Macromolecules, v. 35, p. 2375-2379, 2002.

42. PAN H.; ZHANG Y.; PU H.; CHANG Z., Organic-inorganic hybrid proton exchange membrane based on polyhedral oligomeric silsesquioxanes and sulfonated polyimides containing benzimidazole, J. Power Sources v. 263, p. 195-202, 2014. 
43. GUGGENHEIM S.; MARTIN R. T.; Definition of clay and clay mineral: joint report of the AIPEA nomenclature and CMS nomenclature committees, Clays Clay Miner., v. 43 (2), p. 255-256, 1995.

44. SANTOS, P. S., Ciência e Tecnologia de Argilas, , São Paulo, v. 1, $2^{\mathrm{a}}$ ed, 1989, Ed. Edgard Blücher

45. Imagem do mineral Montmorilonita. Disponível em http://www.geology.neab.net/minerals/montmori.htm Acessado em 22 de Nov. de 2014.

46. PAIVA L. B.; MORALES A. R.;. DÍAZ F. R. V, Argilas organofílicas: características, metodologias de preparação, compostos de intercalação e técnicas de caracterização, Cerâmica v. 54, p. 213-226. 2008.

47. BHARADWAJ R. K.; Modeling the Barrier Properties of Polymer-Layered Silicate Nanocomposites, Macromolecules, v. 34, p. 9189-9192, 2001

48. LAGALY G.; ZIESMER S., Colloid chemistry of clay minerals: the coagulation of montmorillonite dispersions, Adv. Colloid Interface Sci., v. $100-102$, p. 105-128. 2003

49. Estrutura da montmorilonita. Disponível em http://pubs.usgs.gov/of/2001/of01-041/htmldocs/clays/smc.htm Acessado em 20 de Nov. de 2014

50. SINHA RAY S. e BOUSMINA M., Biodegradable polymers and their layered silicate nanocomposites: In greening the 21st century materials world, Prog. Mater. Sci., v. 50, p. 962-1079, 2005.

51. CHOUDALAKIS G. e GOTSISA A. D., Permeability of polymer/clay nanocomposites: A review, Eur. Polym. J., v. 45 (4) p. 967-984, 2009. 
52. WANG T.; WANG M.; ZHANG Z.; GE X.; Fang Y., Grafting of polymers from clay nanoparticles via high-dose gamma-ray irradiation, Mater. Lett., v. 61, p. 3723-3727, 2007.

53. MOET A. S. e AKELAH A., Polymer-clay nanocomposites: polystyrene grafted onto montmorillonite interlayers, Mater. Lett., v. 18, p. 97-102, 1993.

54. LAUS M.; CAMERANI M.; LELLI M.; SPARNACCI K.; SANDROLINI F.; FRANCESCANGELI O., Hybrid nanocomposites based on polystyrene and a reactive organophilic clay, J. Mater. Sci., v. 33, p. 2883 - 2888, 1998.

55. GALEMBECK F. e RIPPEL M. M., Nanocompósitos poliméricos e nanofármacos: fatos, oportunidades e estratégias, In: Parcerias estratégicas, v. 18, p. $41-60,2004$.

56. GOPI J. A.; PATEL S. K.; CHANDRA A. K.; TRIPATHY D. K., SBR-claycarbon black hybrid nanocomposites for tire tread application, J. Polym. Res., v. 18, p. 1625-1634, 2011.

57. CARRETERO-GONZALEZ J.; VERDEJO R.; TOKI S.; HSIAO B. S.; GIANNELIS E. P.; LÓPEZ-MANCHADO M. A., Real-Time Crystallization of Organoclay Nanoparticle Filled Natural Rubber under Stretching, Macromolecules, v. 41 (7), 2008.

58. KARGER-KOCSIS J. e WU C.-M., Thermoset rubber/layered silicate nanocomposites. Status and future trends, Polym. Eng. Sci., v. 44 (6), p. 1083-1093, 2004.

59. ROOJ S.; DAS A.; WERNER K.; OCKELHUBER S.; WANG D-Y.; GALIATSATOS A.; HEINRICH G. Understanding the reinforcing behavior of expanded clay particles in natural rubber compounds, Soft Matter, v. 9, p. 3798-3808, 2013 
60. MOUSA A. e KARGER-KOCSIS J., Rheological and Thermodynamical Behavior of Styrene/Butadiene Rubber-Organoclay Nanocomposites, Macromol. Mater. Eng. v. 286 (4), p. 260-266, 2001.

61. QUAN Y.; WANG Y.; WU Y.; LU M.; ZHA C.; WU X.; ZHANG L. Network Transformations of Highly Dispersed MMT/SBR Nanocomposites During Processing , J. Appl. Polym. Sci, v. 130 (1), p. 113 -119, 2013.

62. HE S-J; WANG Y-Q.; XI M-M.; LIN J.; XUE Y.; ZHANG L-Q., Prevention of oxide aging acceleration by nano-dispersed clay in styrene-butadiene rubber matrix , Polym. Degrad.Stab., v. 98, p. 1773-1779, 2013.

63. ZHANG J.; WANG L.; ZHAO Y., Improving performance of low-temperature hydrogenated acrylonitrile butadiene rubber nanocomposites by using nanoclays, Mater. Design, v. 50, p. 322-331, 2013

64. RAZAVI-NOURI M. e KARAMI M., Effect of rubber content on morphology and thermal and rheological behaviors of acrylonitrile-butadiene rubber / poly(ethylene-co-vinylacetate) / organoclay nanocomposites, Polym., v. 55, p. $6940-6947,2014$.

65. DAS A. K.; SUIN S.; SHRIVASTAVA N. K.; MAITI S.; MISHRA J.K.; KHATUA B.B., Effect of Nanoclay on the Morphology and Properties of Acrylonitrile Butadiene Styrene Toughened Polyoxymethylene (POM)/Clay Nanocomposites, Polym. Comp., v. 35 (2), p. 273 -282, 2014

66. MALI A. D.; SHIMPI N. G.; MISHRA S., Thermal Mechanical and morphological properties of surface modified montmorillonit reinforced Viton rubber nanocomposites, Polym. Int., v. 63, p. 338-346, 2014 
67. ELABDA Y. A. e NAPADENSKY E., Sulfonation and characterization of poly(styrene-isobutylene-styrene) triblock copolymers at high ion-exchange capacities, Polym., v. 45, p. 3037-3043, 2004.

68. BISWAS A.; BANDYOPADHYAY A.; SINGHA N. K.; BHOWMICK A. K., Sulfonation of metallocene-based polyolefinic elastomers and its influence on physicomechanical properties: Effect of reaction parameters, styrene grafting, and pendant chain length, J. Polym. Sci.: Part A: Polym. Chem., v. 46, p. 8023-8040, 2008.

69. OSHIMA A.; IKEDA S.; KATOH E.; TABATA, Y., Chemical structure and physical properties of radiation-induced crosslinking of polytetrafluoroethylene. Rad. Phys. Chem., v. 62, p. 39-45, 2001.

70. OSHIMA A.; IKEDA S.; SEGUCHI T.; TABATA Y., Improvement of radiation resistance for polytetrafluoroethylene (PTFE) by radiation crosslinking Rad. Phys. Chem., v. 49 (2), p. 279-284, 1997.

71. OSHIMA A.; IKEDA S.; SEGUCHI T.; TABATA Y., Change of molecular motion of polytetrafluoroethylene (PTFE) by radiation induced crosslinking Rad. Phys. Chem., v. 49 (5), p. 581-588, 1997.

72. OSHIMA A.; TABATA Y.; KUDOH H.; SEGUCHI T., Radiation induced crosslinking of polytetrafluoroethylene, Rad. Phys. Chem., v. 45 (2), p. 2692730, 1995.

73. OSHIMA A.; IKEDA S.; KUDOH H.; SEGUCHI T.; TABATA Y., Temperature effects on radiation induced phenomena in polytetrafluoroetylene (PTFE)Change of G-value, Rad. Phys. Chem., v. 50 (6), p.611-615, 1997. 
74. OSHIMA A.; SEGUCHI T.; TABATA Y., Radiation-induced free radicals and their behaviour in crosslinked polytetrafluoroethylene (PTFE), Polym. Internat. v. 48, p. 996-1003, 1999.

75. SUN J.; ZHANG Y.; ZHONG X.; ZHU X., Modification of polytetrafluoroethylene by radiation - 1: Improvement in high temperature properties and radiation stability, Rad. Phys. Chem., v. 44, p. 655-659, 1994.

76. YAMAMOTO Y.; SETOGAWA A.; NISHI H., Crosslinked PTFE and applied products, J. Soc. Rubber Ind., Jpn., v. 76, p. 173-177, 2003.

77. FORSYTHE J. S. e HILL D. J. T., The radiation chemistry of fluoropolymers, Prog. Polym. Sci., v. 25, p. 101-136, 2000.

78. LUNKWITZ K.; LAPPAN U.; SCHELER U., Modification of perfluorinated polymers by high-energy irradiation, J. Fluorine Chem., v. 125, p. 863-873, 2004.

79. BANIK I.; DUTTA S.K.; CHAKI T.K.; BHOWMICK A. K., Electron beam induced structural modification of a fluorocarbon elastomer in the presence of polyfunctional monomers, Polym., v. 40, p. 447-458, 1999.

80. CATALDO F.; URSINI O.; ANGELINI G., Radiation-cured polyisoprene/C60 fullerene nanocomposite. Part 1: Synthesis in hexane and in toluene, Rad. Phys. Chem., v. 77, p. 734-741, 2008.

81. PENG J.; XIA H.; ZHAI M.; LI J.; QIAO J.; WEI G., Radiation-induced graft polymerization of maleic acid and maleic anhydride onto ultra-fine powdered styrene-butadiene rubber (UFSBR), Rad. Phys. Chem., v. 76, p. 1741$1745,2007$. 
82. HALDAR S. K. e SINGHA N. K., Grafting of Butyl Acrylate and Methyl Methacrylate on Butyl Rubber Using Electron Beam Radiation, J. Appl. Polym. Sci., v. 101, p. 1340-1346, 2006.

83. EL SAYED A. M., Evaluation of new conducting polymeric membrane based on sulfonation of compatibilized NR/EPDM blend, J. Appl. Polym. Sci., v. 104, p. 3804-3812, 2007.

84. LINARES I., ACOSTA J. L., RODRÍGUEZ S., Proton conducting blends based on polysulfones and elastomers J. Appl. Polym. Sci., v. 100, p. 3474-3482, 2006.

85. GERALDES A. N.; ZEN H. A.; RIBEIRO G.; FERREIRA H. P.; SOUZA C. P.; PARRA D. F.; SANTIAGO E. I.; LUGÃO A. B.; Post-irradiation time effects on the graft of poly(ethylene-alttetrafluoroethylene) (ETFE) films for ion exchange membrane application, Rad. Phys. Chem. , v. 79, p. 246-249, 2010.

86. SHEN M., ROY S., KUHLMANN J. W., SCOTT K., LOVELL K. V., Horsfall J. A., Grafted polymer electrolyte membrane for direct methanol fuel cells, J. Membrane Sci., v. 251, p. 121-130, 2005.

87. CHENGA H.; SCOTT K.; LOVELL K. V.; HORSFALL J. A.; WARING S. C., Evaluation of new ion exchange membranes for direct borohydride fuel cells, J. Membr. Sc., v. 288 (1-2), p. 168-174, 2007.

88. LUFRANO F.; BAGLIO V.; STAITIA P.; ARICO A. S.; ANTONUCCIA V., Polymer electrolytes based on sulfonated polysulfone for direct methanol fuel cells, J. Power Sources, v. 179 (1), p. 34-41, 2008. 
89. ARICÒ A. S.; BAGLIO V.; CRETì P.; DI BLASI A.; ANTONUCCI V.; BRUNEA J.; CHAPOTOT A.; BOZZI A.; SCHOEMANS J., Investigation of grafted ETFE-based polymer membranes as alternative electrolyte for direct methanol fuel cells, J. Power Sources, v. 123, p. 107-115, 2003.

90. SAARINEN V.; KALLIO T.; PARONEN M.; TIKKANEN P.; RAUHALA E.; KONTTURI K., New ETFE-based membrane for direct methanol fuel cell, Electrochim. Acta, v. 50, p. 3453-3460, 2005.

91. BEN YOUCEF H.; GUBLER L.; GÜRSEL S. A.; HENKENSMEIER D.; WOKAUN A.; SCHERER G. G., Novel ETFE based radiation grafted poly(styrene sulfonic acid-co-methacrylonitrile) proton conducting membranes with increased stability, Electrochem. Commun., v. 11 (5), p. 941-944, 2009.

92. GUBLER L.; SLASKIA M.; WALLASCH F.; WOKAUN A.; SCHERER G. G., Radiation grafted fuel cell membranes based on co-grafting of $\alpha$ methylstyrene and methacrylonitrile into a fluoropolymer base film, $J$. Membr. Sci., v. 339 (1-2), p. 68-77, 2009.

93. FERNANDES A. C. e TICIANELLI E. A., A performance and degradation study of Nafion 212 membrane for proton exchange membrane fuel cells, $\boldsymbol{J}$. Power Sources, v. 193, p. 547-554, 2009.

94. HASSAN A.; PAGANIN V. A.; TICIANELLI E. A., Pt modified tungsten carbide as anode electrocatalyst for hydrogen oxidation in proton exchange membrane fuel cell: CO tolerance and stability, Appl. Catal. B: Environ., v. 165, p. 611-619, 2015. 
95. LAGE L. G.; DELGADO P. G.; KAWANO Y., Thermal stability and decomposition of Nafion ${ }^{\circledR}$ membranes with different cations, J. Therm. Anal. Calorim., v. 75 (2), p. 521-530, 2004.

96. ANNUAL BOOK OF ASTM STANDARDS. Standard Practice for RubberMaterials, Equipment, and Procedures for Mixing Standart Compounds and Preparing Standard Vulcanized Sheets . v. 09.01, 2008 (ASTM D-3182).

97. PETROBRAS PETROLEO BRASIL SA. Ademar B. Lugão; Adriana N. Geraldes; Duclerc F. Parra; Heloísa A. Zen; Geise Ribeiro. Method for obtaining copolymer for grafting matrix polymer, involves mixing a monomer, diluents and na array of polymer in inert atmosphere, which contains nitrogen. BR 201105889 A2, 06 out. 2011.

98. ANNUAL BOOK OF ASTM STANDARDS. Standard Test Methods for Vulcanized Rubber and Thermoplastic Rubber and Thermoplastic Elastomers - Tension. v. 09.01, 2008 (ASTM D-412).

99. ANNUAL BOOK OF ASTM STANDARDS. Standard Test Method for Rubber Property - Durometer Hardness. v. 09.01, 2008 (ASTM D-2240).

100. ANNUAL BOOK OF ASTM STANDARDS. Standard Test Method for Rubber Property - Vulcanization Using Oscillating Disk Cure. v. 09.01, 2008 (ASTM D-2084).

101. ANNUAL BOOK OF ASTM STANDARDS. Standard Test Method for Rubber, Raw - Determination of Gel, Swelling Index, and Dilute Solution Viscosity. v.09.01, 2008 (ASTM D-3616).

102. FOSTER, M. D. Geochemical studies of clay minerals: II relation between ionic substitution and swelling in montmorillonite. Am. Mmineral, v. 38, p. 994-1006, 1953 
103. PEREIRA K. R. O.; RODRIGUES M. G. F; DIAZ F. R. V., Síntese e caracterização de argilas organofílicas: comparação no uso de dois métodos, Revista Eletrônica de Materiais e Processos, v. 2 (2), p. 01-08, 2007.

104. VALENZUELA-DÍAZ F. R.; Preparation of organophilic clays from a Brazilian smectitic clay Key Eng Mat, v. 189-191, p. 203-207, 2001.

105. ARAúJo A. L. P.; SilVA M. C. C.; GIMENES M. L.; BARROS M. A. S. D., Estudo termodinâmico da adsorção de zinco em argila bentonita calcinada, Scientia Plena, v. 5, p. 124-201, 2009.

106. LEITE I. F.; RAPOSO C. M. O.; SILVA S. M. L., Caracterização estrutural de argilas bentoníticas nacional e importada: antes e após o processo de organofilização para utilização como nanocargas, Cerâmica, v. 54, p. 303308, 2008.

107. XIE W.; GAO Z.; LIU K.; PAN W. P.; VAIA R.; HUNTER D.; SINGH A., Thermal characterization of organically modified montmorillonite, Thermochim. Acta , v. 367, p. $339-350,2001$

108. ANAdÃO P.; HILdebRANDO E. A.; PAJOLLI I. L. R.; PEREIRA K. R. O.; WIEBECK H.; DÍAZ F. R. V., Montmorillonite/carbon nanocomposites prepared from sucrose for catalytic applications, Appl. Clay Sci. v. 53, p. 288-296, 2011.

109. CHIGWADA G.; JIANG D. D.; WILKIE C. A., Polystyrene nanocomposites based on carbazole-containing surfactants, Thermochim. Acta v. 436, p. 113-121, 2005.

110. BHARADWAJ R. K.; Modeling the Barrier Properties of Polymer-Layered Silicate Nanocomposites, Macromolecules, v. 34, p. 9189-9192, 2001 
111. CHEN C.; HUANG S.; CHEN M.; LU Q., Synthesis and characterization of three kinds of bifunctionalized polyhedral oligomeric silsesquioxanes with the same cage structure, High Perform. Polym. v. 24 (2), p. 119-124, 2012.

112. ADACHI, K.; NAKAMOTO, T.; KOTAKA, T. Swelling Equilibrium of Solution Cross-Linked Polybutadieno Networks in Polyisoprene Solutions, Macromolecules. v. 22, p. 3106-3111, 1989.

113. MITRA S.; GHANBARI-SIAHKALI A.; KINGSHOTT P.; HVILSTED S.; ALMDAL K., Chemical Degradation of an Uncrosslinked Pure Fluororubber in an Alkaline Environment, J. Polym. Sci.: Part A: Polym. Chem., v. 42, p. 6216-6229, 2004.

114. ITO M., Radiation induced degradation of fluorine containing elastomers at various temperatures, Radiat. Phys. Chem. v. 47 (4), p. 607-610, 1996.

115. EDWARDS S. F. e VILGIS T. A., The tube model theory os rubber elasticity, Rep. Prog. Phy. v. 51, p. 243-297, 188

116. ZHEN S. J., The effect of chain flexibility and chain mobility on radiation crosslinking of polymers, Radiat. Phys. Chem. v.60, p. 445-451, 2001.

117. ZHANG W. I., ZHANG Y. F., QI C. Z., SUN J. Z., The effect of chain flexibility of fluoropolymers on their radiation crosslinking behavior, Radiat. Phys. Chem. v. 31, p. 575-578, 1988.

118. WITTEN T. A.; RUBINSTEIN M.; COLBY R. H., Reinforcement of rubber by fractal aggregates, J. Phys. II France, v. 3, p. 367-383, 1993.

119. STRAT D. L.; DALMAS F.; RANDRIAMAHEFA S.; JESTIN J.; WINTGENS V., Mechanical reinforcement in model elastomer nanocomposites with tuned microstructure and interactions, Polym., v. 54, p. $1466-1479,2013$ 
120. JANCAR J.; DOUGLAS J. F. ; STARR F. W. ; KUMAR S. K. ; CASSAGNAU P.; LESSER A. J.; STERNSTEINH S. S.; BUEHLERB M. J., Current issues in research on structure/property relationships in polymer nanocomposites, Polym., v. 51 (15), p. 3321-3343, 2010

121. DALMAS F.; CAVAILLÉ J-Y.; GAUTHIER C.; CHAZEAU L.; DENDIEVEL R., Viscoelastic behavior and electrical properties of flexible nanofiber filled polymer nanocomposites. Influence of processing conditions, Comp. Sci. Technol., v. 67 (5), p. 829 - 839, 2007.

122. GAO J.; GU Z.; SONG G.; LI P.; W. LIU, Preparation and properties of organo- montmorillonite/fluoroelastomer nanocomposites, Appl. Clay Sci., v. 42, p. 272-275, 2008.

123. ZHANG Z.; ZHANG L.; LI Y.; XU H., New fabricate of styrene-butadiene rubber/montmorillonite nanocomposites by anionic polymerization, Polym., v. 46, p. 129-136, 2005.

124. DARGAVILLE T. R. Studies of the radiation chemistry and grafting of a fluoropolymer. 2002. Tese (Doutorado) - The University of Queensland, Austrália. 